UNIVERSIDADE DE SÃO PAULO

FACULDADE DE FILOSOFIA, LETRAS E CIÊNCIAS HUMANAS PROGRAMA DE PÓS-GRADUAÇÃO INTERDISCIPLINAR HUMANIDADES, DIREITOS E OUTRAS LEGITIMIDADES

PATRICIA JULIA LEWIS CARPIO

Peruanos comerciantes na Feirinha da Madrugada no bairro do Brás em São Paulo: trabalho, direito à moradia e lazer em contexto de imigração

São Paulo

2018 
UNIVERSIDADE DE SÃO PAULO

FACULDADE DE FILOSOFIA, LETRAS E CIÊNCIAS HUMANAS PROGRAMA DE PÓS-GRADUAÇÃO INTERDISCIPLINAR HUMANIDADES, DIREITOS E OUTRAS LEGITIMIDADES

Peruanos comerciantes na Feirinha da Madrugada no bairro do Brás em São Paulo: trabalho, direito à moradia e lazer em contexto de imigração

Patricia Lewis Carpio

Dissertação de mestrado apresentada ao Programa de Pós-Graduação Humanidades Direito E Outras Legitimidades da Faculdade de Filosofia, Letras e Ciências Humanas - Universidade de São Paulo, para a obtenção do titulo de Mestre em Ciências Humanas.

Orientador: Prof. Dr. Luis Guilherme Galeão da Silva.

São Paulo 
Autorizo a reprodução e divulgação total ou parcial deste trabalho, por qualquer meio convencional ou eletrônico, para fins de estudo e pesquisa, desde que citada a fonte.

Catalogação na Publicação Serviço de Biblioteca e Documentação

Faculdade de Filosofia, Letras e Ciências Humanas da Universidade de São Paulo

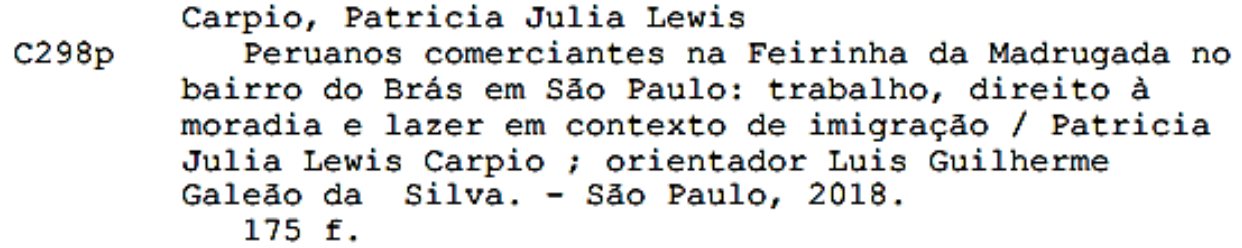

1. Imigraçåo peruana. 2. Trabalho precário. 3. Direito a moradia. 4. Lazer. I. Silva, Luis Guilherme Galeảo da, orient. II. Título. 
PATRICIA LEWIS CARPIO

\section{Peruanos comerciantes na Feirinha da Madrugada no bairro do Brás em São Paulo: trabalho, direito à moradia e lazer em contexto de imigração}

Dissertação de mestrado apresentada ao Programa de Pós-Graduação Humanidades Direito E Outras Legitimidades da Faculdade de Filosofia, Letras e Ciências Humanas - Universidade de São Paulo, para a obtenção do título de Mestre em Ciências Humanas.

\section{COMISSÃO EXAMINADORA}

\section{Prof. Dr. Luis Guilherme Galeão da Silva}

Universidade de São Paulo

Faculdade de Filosofia, Letras e Ciências Humanas

Avaliador (a) I

Avaliador (a) II

Avaliador (a) III

São Paulo

2018 
Faz parte de nossas utopias uma sociedade mais justa, onde o homem possa se libertar das amarras impostas pela formação econômica e social capitalista, onde seu trabalho possa ser criativo, seu horário de lazer algo mais que o "repouso físico"; sua habitação, algo mais que um teto; e onde os homens tenham assegurado, na prática, o direito à vida, à felicidade e à diferença. 


\section{RESUMO}

LEWIS, Patricia Julia. Peruanos comerciantes na Feirinha da Madrugada no bairro do Brás em São Paulo: trabalho, direito à moradia e lazer em contexto de imigração. 2018. 175 f. Dissertação (Mestrado em Humanidades, Direito e outras Legitimidades) - Faculdade de Filosofia, Letras e Ciências Humanas, Universidade de São Paulo, São Paulo, 2018.

O presente estudo analisa o deslocamento e inserção de imigrantes comerciantes na cidade de São Paulo a partir das histórias de vida de peruanos trabalhadores ambulantes na Feirinha da Madrugada no bairro do Brás. Partindo do depoimento dos entrevistados, assim como das observações de campo à feirinha, dos espaços de lazer e atividades de tempo livre, procurou-se conhecer as diversas dimensões do vivido em contexto de imigração, tendo como principais eixos de análise a questão do trabalho precário, direito à moradia e lazer. Procura-se, contudo contribuir para o conhecimento do fenômeno migratório contemporâneo no Brasil dando um rosto mais humano à abordagem da realidade dos milhares de pessoas que se deslocam em busca de melhores condições de vida, reconhecendo-os como indivíduos sociais, de direito e protagonistas da sua própria história.

Palavras chave: Imigração peruana. Trabalho precário. Direito a moradia. Lazer. 


\begin{abstract}
LEWIS, Patricia Julia. Peruvian merchants at Midnight Fair in the neighborhood of Brás in São Paulo: work, right to housing and recreation in the context of immigration. 2018. 175 f. Dissertação (Mestrado em Humanidades, Direito e outras Legitimidades) - Faculdade de Filosofia, Letras e Ciências Humanas, Universidade de São Paulo, São Paulo, 2018.
\end{abstract}

The present study analyzes the displacement and insertion of commercial immigrants in the city of São Paulo from the life stories of Peruvian mobile workers at Midnight Fair in the district of Brás. Based on the interviewees' testimony, as well as the field observations to the fair, recreation spaces and free time activities, we sought to know the different dimensions of the lived in immigration context, having as main axes of analysis the issue of precarious work, right to housing and leisure. It seeks to contribute to the knowledge of the contemporary migratory phenomenon in Brazil giving a more humane face in approaching the reality of the thousands of people who move in search of better living conditions, recognizing them as social individuals, in law and protagonists of its own history.

Keywords: Peruvian immigration. Precarious work. Right to housing. Recreation. 


\section{LISTA DE FIGURAS}

Figura 1: Feirinha da madrugada do Brás

Figura 2: Mapa do principal ponto da Feirinha de madrugada do Brás ......................... 10

Figura 3: Mapa da divisão política do Peru ............................................................... 30

Figura 4: Camelos da Feirinha da Madrugada do Brás no quinto dia de protestos contra a “Operação de combate aos camelos” em outubro de 2011 ........................................... 82

Figura 5: Restaurante peruano no centro da cidade de São Paulo................................ 137

Figura 6: Quadra esportiva Arena Central situada na rua Guaianases no centro de São Paulo

Figura 7: Cartilha convite a uma Pollada realizada em Lima com motivo de saúde ... 148 Figura 8: Pollada com motivo de financiar gastos com a justiça contra a entrada de empresas mineradoras no povoado de Chacralla. 148

Figura 9: Pagina principal de um jornal peruano no dia seguinte do massacre em uma pollada em Lima 150

Figura 10: Passeata dos caixões com as pessoas assassinadas na matança de Bairros Altos em Lima 150

Figura 11: Senhores peruanos na preparação da pollada em Paraisópolis 153

Figura 12: Preparação de uma pollada em Paraisópolis 153

Figura 13: Imigrantes peruanos assistindo jogo de futebol em Paraisopolis 155

Figura 14: Peruanos assistindo jogo de futebol em Paraisópolis 155

Figura 15: Cartaz com informações previas do Campeonato Latinoamericano 156

Figura 16: Seleção boliviana de futebol feminino juvenil. Campeonato Latinoamericano de futsal, Arena Central- São Paulo 158

Figura 17: Seleção de jovens peruanos nos jogos eliminatórios para o Campeonato Latinoamericano 158

Figura 18: Espectadores e torcedores apoiando seus times 159

Figura 19: Troféus para a premiação do final do Campeonato 159 


\section{SUMÁRIO}

INTRODUÇÃ

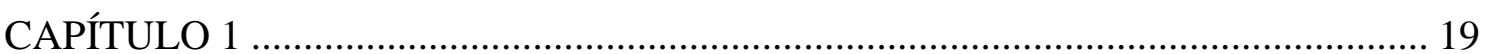

1. CONTEXTUALIZAÇAO DA IMIGRAÇAON PERUANA NO BRASIL ........... 19

1.1. História da imigração no Brasil ......................................................................... 20

1.2. A nova cara da imigração para o Brasil ............................................................ 27

1.2.1. A imigração peruana em São Paulo ......................................................... 28

1.3. Contexto histórico social do Peru contemporâneo ............................................. 29

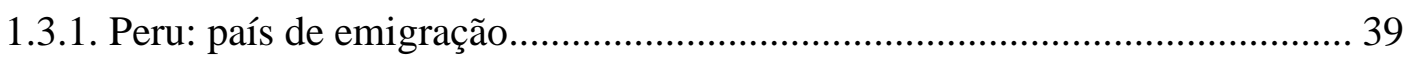

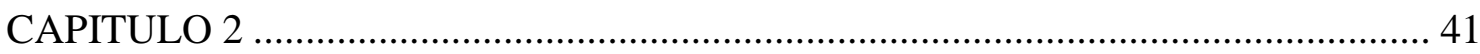

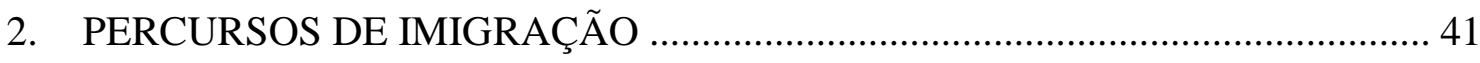

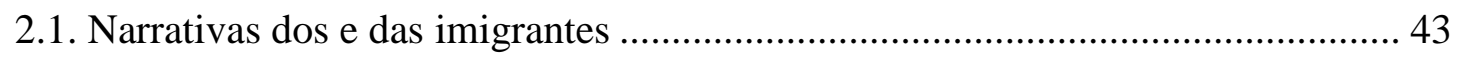

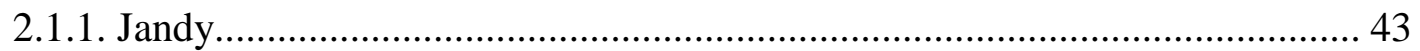

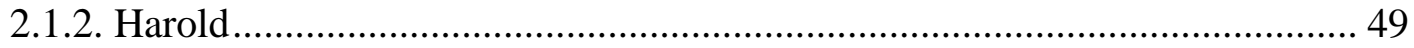

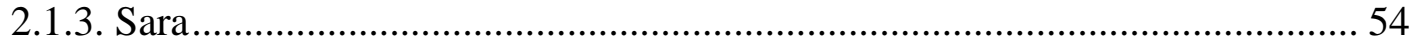

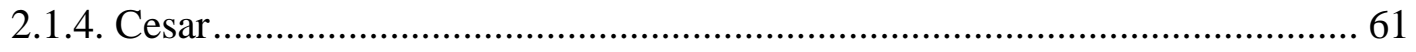

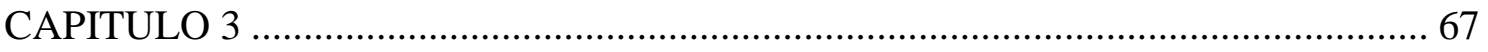

3. O TRABALHO DOS IMIGRANTES PERUANOS NA FEIRINHA DA

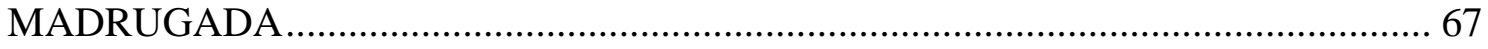

3.1. Espaço e território em contexto de imigração....................................................... 68

3.2. Os imigrantes no mercado de trabalho brasileiro ............................................. 72

3.3. Peruanos comerciantes na feirinha de madrugada do Brás- SP .......................... 75

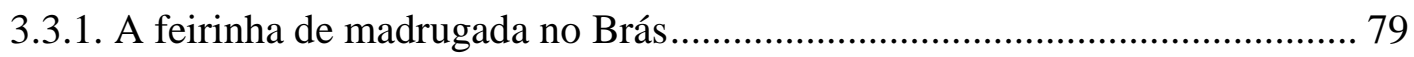


CAPITULO 4

4. O DIREITO À MORADIA EM CONTEXTO MIGRATÓRIO

4.1. Imigração e direito à moradia

4.2. O problema da moradia no Brasil 116

4.3. A habitação dos imigrantes 118

4.4. Narrativas dos e das imigrantes - A questão da moradia 119

4.5. Análise das entrevistas. 128

\section{CAPITULO 5}

5. O LAZER DOS IMIGRANTES

5.1. O tempo livre na cidade: lugares e atividades de lazer dos imigrantes peruanos

5.2. Narrativas dos e das peruanas imigrantes 138

5.3. Análise das entrevistas.

5.4. As polladas e os campeonatos de futebol: duas celebrações populares na comunidade imigrante. 


\section{INTRODUÇÃO}

Para entender a trajetória de pesquisa é necessário contar um pouco sobre minha trajetória de vida e os percursos que me levaram a estudar a migração dos meus próprios conterrâneos em terras paulistanas.

Venho de uma família numerosa cujas origens remetem a uma pequena cidade portuária ao sul do país, lugar onde passaram muitas gerações até a imigração dos meus pais para a capital do estado. Aquela cidade de porto era pequena, porém, muito movimentada e cuja dinâmica se desenvolvia a partir do mar e tudo do que dele chegava. Grandes embarcações repletas de mercadoria e pessoas chegavam quase diariamente, e cuja dinâmica intensificou-se a começos do século XX. Homens, mulheres e famílias inteiras chegavam do outro lado do oceano para começar uma vida no litoral peruano, a mesma dinâmica que caracterizou os fluxos migratórios dos demais países da região. Nas historias das minhas avós, tias e mãe sempre estavam presentes relatos de famílias chinesas que chegavam ao porto com grandes malas, as grandes lojas de tecido dos árabes, as lojas de eletrodomésticos dos japoneses, a sorveteria do casal italiano. Dezenas de álbuns com antigas fotografias das praças principais da cidade e, sobretudo do porto ajudavam a recriar a cidade daquela época.

Muitos anos depois, o deslocamento passou de ser uma paisagem em preto e branco a uma realidade vivida por minha própria família, e não necessariamente tão pitoresca quanto às histórias da minha avó sobre os dramas da família palestina do centro da cidade. No ano 1999 minha irmã mais velha partiu ao exterior com uma bolsa de estudos para estudar por um período de tempo, período que se estenderia até os dias de hoje. Na época foi uma das despedidas mais dolorosas para todos e todas, inclusive para minha pequena sobrinha de cinco anos quem na época tal vez não entendia muito os motivos da partida. Os meios para se comunicar não eram tão avançados quanto os de agora. Assim que cada domingo à noite, a gente teria que fazer fila e esperar por seu turno para falar com minha irmã, sendo as perguntas quase sempre as mesmas - "como é a vida por lá? o que você come? As pessoas são boas? Você esta feliz? Quando você volta? Saudades!”. Sei agora que o mais importante não era só o que ela falava, mas também o que calava. Os vazios e tristezas ocasionados pela ausência, até as ânsias e alegrias extremas pela chegada foram dois ciclos constantes na vida da minha família 
por um longo período de tempo, onde a pergunta - "Quando você volta? - foi se substituindo implicitamente por todos por - "Quando você nos visitará de novo"?", aceitando de aos poucos que nossa irmã não voltaria mais.

Eu empreendi minha própria viagem em fevereiro de 2014, sendo vários os motivos, alguns do coração, outros da cabeça; umas pensadas com carinho e curiosidade, outras com desespero e impulso. Os quatro meses que foi o período previsto para minha estadia se estenderia também até o dia de hoje. As causas da minha chegada ao Brasil não foram nem estudo nem trabalho, como muitos desejariam que eu respondesse, foi além disso. $\mathrm{O}$ destino assim me trouxe a uma terra no nordeste, onde aos poucos fui reinventando-me e fortalecendo-me, -"torna-te o que tu és" - como falou para mim certa pessoa nas minhas primeiras semanas no cálido Ceará.

E como é que sempre acabam as melhores coisas, um motivo burocrático pôs fim a minha "experiência tropical" para me trazer à terra da garoa e das catracas. Já "legalizada" no país e morando agora na caótica cidade de São Paulo, cidade também das grandes oportunidades, comecei a formular a ideia de estudar e ficar mais um tempo no Brasil. Conheci a Universidade de São Paulo a traves de alguns amigos no ano 2013, ano que comecei a frequentar o Núcleo de Historia Oral no departamento de Historia, o que me motivou e reforçou minha vontade de estudar e começar a pesquisar sobre os imigrantes peruanos na cidade de São Paulo, aprofundando nos seus relatos pessoais e historias de vida.

Traz dar inicio no mestrado no Programa Diversitas, começaram também muitas duvidas sobre onde e a quem começar a entrevistar assim como uma grande incerteza sobre se as redes que escolheria para entrevistar representariam realmente a realidade da imigração peruana na cidade.

$\mathrm{Na}$ minha primeira tentativa por coletar historia de vida, vivencias e experiências procurei peruanos em situações muito diversas. Desde as visitas ao consulado peruano, sociedades de difusão da cultura peruana, até representantes de Ongs diversas me levaram a questionar se a voz desses imigrantes refletiria a realidades dos milhares peruanos estabelecidos em São Paulo. Uma entrevista especifica me levou a questionar muitos aspetos relacionados não só á imigração, como também à realidade do meu próprio pais, realidade cuja característica principal é a profunda desigualdade social, assim como racismo e diversas formas de discriminação e exclusão.

Um dos entrevistados indicados pelos funcionários do consulado foi uma pessoa com 30 anos morando no Brasil, o qual se fazia chamar de "o amante da cultura 
peruana" e cujo circulo social estava conformada por outros peruanos de classe media e com relações diretas com o consulado e encarregado de organizar eventos culturais de difusão da cultura peruana. Dentro da fala deste personagem não faltaram comentários para menosprezar o que ele denominou de "os novos peruanos", caracterizando aos peruanos recém-chegados como pobres e ladroes que prejudicam a "imagem" do Peru. Vejamos o seguinte depoimento:

E começou a aparecer uma nova imigração, o imigrante que é pobre e que vem para trabalhar de qualquer coisa, o imigrante que já é choleado $^{l}$, o imigrante que parece com boliviano... esse já é outro tipo de imigração. (...) eu vim numa época onde os peruanos que viviam aqui pertenciam a uma colônia privilegiada, uma geração que veio para estudar, que pertenciam a famílias com classe e dinheiro e conseguiram trabalhos maravilhosos. (...) por isso os imigrantes novos vão sofrer um pouco porque não tem as condições de ver o lindo que é o Brasil. Porque não vivem essa experiência com brasileiros, a vivem com peruanos. Então eles mudam só de lugar. Não conseguem conhecer a possibilidade que é o Brasil, de estar com os brasileiros. $\mathrm{O}$ brasileiro é uma pessoa muito boa, não é mau, não é como a gente. Nós somos maus, somos aproveitadores, somos sem vergonha, nós criamos confusão onde não tem. Por muitos anos eu não tive contato com peruanos, meus contatos têm sido basicamente brasileiros. Por isso é que minha filha só fala português. Eu era chamado de chileno porque falo espanhol e sou branco. No começo ficava incomodado, mas depois eu calava porque a colônia de peruanos que começava a aparecer era ruim, eram bandidos, indecentes. Então assumi outra identidade para que não me sinalem de ladrão. Tínhamos vergonha de que nos reconheçam como peruanos. Ate agora, se você chama de peruana a minha filha ela fica envergonhada. (entrevistado)

Os depoimentos do entrevistado me provocaram uma serie de sensações - e malestares- mas ao mesmo tempo me ajudou a refletir sobre muitas coisas e problemáticas da própria sociedade à que pertenço. A sua vez me deu muitas ideias e caminhos possíveis a seguir, assim como mudar de rumo e de rede de entrevistados, o que me levou a querer conhecer a esses "novos peruanos de pouca classe" que o primeiro entrevistado fez questão de enfatizar. Comecei a frequentar algumas outras organizações no centro da cidade que me disponibilizaram informações importantes para minha pesquisa, o que me levou a definir a rede para ser pesquisada.

Foi assim que baseando-me em dados de diversas organizações, visitas a diversos lugares e regiões da cidade com muita presença de imigrantes, entrevistas realizadas com diversas pessoas, e sobretudo o fato de conhecer uma comerciante de rua com a qual guardo uma linda relação de amizade até hoje e que foi de grande ajuda na

\footnotetext{
${ }^{1}$ Cholo é um termo depreciativo usado comumente no Peru para chamar às pessoas indígenas.
} 
minha pesquisa, foi que decidi focar este estudo nos peruanos imigrantes trabalhadores no comercio de rua, em um mercado popular especifico chamado de Feirinha da Madrugada na região do Brás, o que me levaria à descoberta de um mundo de particularidades e formas diversas de viver e sobrelevar a experiência migratória, experiências desses "outros peruanos" que com o passar do tempo fui conhecendo e admirando muito.

Para falar de migração, consideram-se relevantes os estudos levados a cabo por Sayad (1998), para quem a imigração é um fato social total. Na sua obra "A imigração ou os paradoxos da alteridade" Sayad faz uma crítica às maneiras tradicionais de abordar a migração, sobretudo nos países de imigração, os quais reduzem o fenômeno migratório ao deslocamento de força de trabalho, deixando de lado os motivos pelos quais os sujeitos migram. Segundo o autor, o imigrante vive num estado de contrariedade entre uma situação provisória que pode durar indefinidamente e uma situação duradoura que nunca é aceita como definitiva e a qual gosta de viver com provisoriedade. Essa ilusão de provisoriedade envolve a todos os atores da imigração: o próprio sujeito emigrante/imigrante, a sociedade emigrante e a sociedade imigrante.

Diante de uma sociedade hostil, os imigrantes tentam convencer-se de que estão frente a uma situação provisória. Por outro lado, a sociedade de origem considera os seus emigrantes como simples ausentes e, independente do tempo da ausência, os incita a voltar para o lugar que abandonaram provisoriamente. Por último, na sociedade de imigração o imigrante é definido como trabalhador estrangeiro e existe apenas em condição provisória, podendo ser indeterminada dependendo do grau de interesse que se tenha sobre o imigrante, interesse geralmente econômico. Para Sayad:

Um imigrante é essencialmente uma força de trabalho, e uma força de trabalho provisória, temporária, em transito. A final, um imigrante só tem razão de ser no modo do provisório e com a condição de que se conforme ao que se espera dele; ele só esta aqui e só tem sua razão de ser pelo trabalho e no trabalho; porque se precisa dele, enquanto se precisa dele e lá onde se precisa dele (op. cit. p.54).

Desse ponto de vista o imigrante é visto como mão de obra disposto a satisfazer as necessidades do momento. Na lógica materialista da sociedade de "acolhida" o trabalhador imigrante é apenas tolerado provisoriamente na medida em que aporte vantagens -econômicas-, antes que custos -sociais e culturais-. Devido a isso, os estatutos do imigrante estão baseados num enfoque laboral, econômico e até político ou 
de defesa nacional. A presença do imigrante estaria justificada e condicionada unicamente pelo trabalho, sendo a situação de desemprego inconcebível e impensável. O imigrante é visto muitas vezes ainda como culpado pelo desemprego das pessoas nativas do país em que imigrou.

Diante do olhar etnocentrista na abordagem das migrações no meio acadêmico como são as ciências jurídicas, demográficas e geográficas, a imigração tem se constituído, pensado e definido ao longo do tempo como uma problemática social. Ideia não apenas compartilhada pelos intelectuais, mas também pela sociedade, reproduzindo uma representação coletiva do imigrante baseada numa série de problemas sociais como desemprego, falta de moradia, desadaptação, problemas de saúde, etc. além desse olhar que problematiza a condição do imigrante, estão as atribuições mínimas em direito que são aceitas como "suficientes" para essa população, como são nos casos de moradia quase sempre o pior- e do sistema de saúde - o mais econômico e rápido- sobrepondo sua condição de imigrante à sua condição de humano, a qual se encontra diminuída e mutilada em termos de legitimidades.

Iokoi (2008) assinala no seu artigo "Imigrantes Invisíveis" o sentido paradoxal dos fluxos migratórios na modernidade. O deslocamento de indivíduos propicia cenários para manifestações de intolerância expressadas contraditoriamente por nacionalismos e xenofobias, onde o imigrante é considerado o intruso pertencente a outro lugar. Esses cenários de intolerância seriam as metrópoles, que são gestoras do processo de globalização e lugar onde o discurso dominante político e intelectual problematiza o fenômeno da imigração:

Os migrantes revelam os limites do funcionamento dos sistemas sociais, as margens, os pontos de exclusão, sua condição de extrema estigmatização social, conformando a imagem do que a cidade rejeita. As migrações permitem a análise pormenorizada da lógica da ordem urbana (op. cit. p.3).

As pesquisas em migração deveriam amplificar a voz dos imigrantes através das suas próprias narrativas de vida, analisando os motivos que levam milhares de pessoas a migrar e as particularidades na trajetória de cada um desses indivíduos. Compreender o significado de estar longe de casa e a constante sensação de estar e não estar, ser e não ser social. Apontamentos que nos ajudem a repensar as legitimidades da cidadania, legitimidades estas muitas vezes negadas ao "outro" que não pertence a uma 
determinada comunidade de língua, cultura e raça e que é visto como uma ameaça à identidade centrada no estado.

\section{Sobre a metodologia}

Para pensar e compreender o fenômeno migratório na contemporaneidade, junto a todos os processos, efeitos e complexidades, precisa-se de um olhar mais abrangente, capaz de enxergar as diferentes dimensões do mesmo, dimensões que vão além do deslocamento físico. A migração trata-se de um conjunto de processos sociais, culturais, históricos, etc., que requerem de uma análise desde estas diferentes perspectivas, levando sempre em consideração a importância da própria experiência do imigranteemigrante. Ao analisar o fenômeno migratório, focaliza-se a atenção no trabalhador e não mais no trabalho, voltando o interesse no aspecto social:

Interessam-nos os múltiplos aspectos envolvidos no processo, como
relações de gênero, arranjos e desarranjos familiares, representações
sociais, discursos e interpretações de aqueles que se deslocam sobre o
próprio deslocamento, enfim, análise da migração como um processo
social total (IOKOI, 2013.p9).

É a partir desse pressuposto e baseando-nos na procura de uma maior compreensão sobre as diferentes dimensões do processo migratório é que se optou pelo uso de entrevistas em história oral como o recurso mais adequado para recolher a partir das narrativas dos sujeitos as particularidades do processo migratório vivenciada por cada indivíduo grupo e comunidade. Por sua vez se fez uso da observação direta como um método que possibilitou uma maior aproximação e melhor conhecimento sobre as formas de sociabilidade dos imigrantes dentro e fora do mundo do trabalho, junto às disputas, conflitos e negociações pelo espaço.

A História Oral é um método de pesquisa que tem como finalidade principal criar fontes históricas (FREITAS, 2002). Fazendo uso de entrevistas em articulação com outros procedimentos, registra as narrativas da experiência humana, originando assim um tipo de documentação de importantíssimo valor histórico e social que deve ser devidamente registrado, armazenado e conservado para posteriores análises. É um método de grande abrangência interdisciplinar que pode ser usada nas diferentes ciências humanas como na história, sociologia, psicologia, antropologia, etc. 
As fontes orais são também um instrumento de luta política contra os discursos dominantes (CUSICANQUI, 2015). A potencialidade das oralidades radica em produzir outros conhecimentos e em revelar saberes, em outras palavras, a necessidade de uma descolonização intelectual a fim lutar contra um discurso hegemônico e generalizante que silencia e oculta as experiências de vida de pessoas excluídas na sociedade e na produção científica. As fontes orais permitem conhecer novas histórias, sendo um espaço para a reconstrução das trajetórias individuais e coletivas de diversos grupos sociais reprimidos. São um valioso aporte metodológico e epistemológico para os estudos migratórios, revelando as realidades vividas pelos imigrantes, o desenraizamento do lugar de origem, os dilemas na construção e reconstrução de identidades, as relações com a nova sociedade, a problemática entorno dos direitos e legitimidades.

Por sua vez, para Meihy (2007) Historia Oral é, basicamente, "um recurso moderno usado para a elaboração de documentos, arquivamento e estudos referentes à vida social das pessoas" (op. cit. p, 13). Ela é sempre uma história do tempo presente, é também conhecida como história viva ao tratar-se da experiência de grupos e pessoas vivas. Para o autor, essa metodologia é também uma forma de saber que requer planejamento do uso e sentido que se da às entrevistas, consideradas relevantes e significativas para o conhecimento e compreensão de fatos considerados relevantes. "Sabedoria, como forma de conhecimento diz respeito à valorização da experiência humana, de maneira a elevar o sentido moral da vivencia individual e coletiva" (op. cit. $\mathrm{p}, 74)$.

Os elementos básicos que aparecem na História oral são o entrevistador e o entrevistado que atuam como colaboradores da entrevista, e a aparelhagem de gravação como um recurso eletrônico que auxilia tanto no momento da gravação das entrevistas, quanto na conservação do material recolhido para seu arquivamento e futuros análises na esfera social. Por sua vez, são três os gêneros distintos que nos oferece a Historia Oral: história de vida, história temática e tradição oral. A história de vida é a narrativa feita pelo sujeito entrevistado sobre sua própria experiência de vida e esta relacionada com a reconstrução do passado, dependendo diretamente da memória e da subjetividade dos indivíduos. A História temática é a história oral em caráter específico onde existe um tema ou foco central que guia o transcurso da entrevista e geralmente vai acompanhada de um questionário. A tradição oral ajuda a revelar aspectos de uma determinada cultura, a qual na maioria das vezes carece de história escrita. É uma 
excelente ferramenta para a preservação de tradições, mitos, costumes e conhecimentos que são transmitidas através da oralidade de geração em geração.

A entrevista em História Oral atua como uma facilitadora para o entendimento da sociedade, onde o entrevistado é considerado um agente histórico cuja voz e experiência torna-se parte fundamental da pesquisa. Desde esta perspectiva, as histórias adquirem um sentido social ao contribuir com o conhecimento da experiência e trajetória humanas como componente inerente da dinâmica social.

Assim, através das histórias de vida pretende-se personificar a imigração peruana em São Paulo e dar a conhecer a realidade de peruanos e peruanos trabalhadores ambulantes que empreendem uma viagem rumo ao Brasil com a ilusão de um futuro melhor. É necessário analisar como os peruanos vivenciam sua experiência migratória no país, especificamente na capital paulista e, sobretudo as questões que fazem referência aos motivos que os levaram a sair de seu país de origem, as dinâmicas e mecanismos de sociabilização com brasileiros e outros conterrâneos, processos de territorialização, e questões relacionadas à moradia e trabalho.

\section{Observação - descrição}

Outra proposta teórica-metodológica foi a observação e descrição de trabalho de campo como resultado de várias visitas à feirinha de madrugada no bairro do Brás, observações das diferentes atividades de lazer dos comerciantes peruanos como celebrações, festa populares e campeonatos de futebol, assim como visitas aos lugares de moradia dos entrevistados. Para Silva (2014, p.33) “descrever é um recurso analítico para repensar as categorias com as quais analisamos o mundo social em um contexto marcado por transformações". Nesse sentido, ao fazer uso da observação e a descrição pretende-se dar a conhecer os mecanismos e dinâmicas dentro do contexto da feirinha assim como as sociabilidades, disputas e conflitos dentro do espaço; da mesma maneira com as atividades de lazer e de tempo livre no contexto de migração. 


\section{Objetivo da pesquisa}

O objetivo principal dessa pesquisa foi analisar o deslocamento e a experiência migratória de peruanos e peruanas trabalhadores ambulantes na cidade de São Paulo através de suas histórias de vida.

\section{Apresentação dos entrevistados}

Ao longo do presente estudo foram realizadas sete entrevistas. Porém uma vez definido o recorte espacial, apenas quatro delas foram consideradas para a análise do estudo. O primeiro fato em comum entre todos os entrevistados é o trabalho ambulante na Feira da Madrugada do Brás. Além desse, os conflitos, negociações e sociabilidades dentro e fora desta feira fazem parte rotina de cada um dos entrevistados. Seja na venda de roupa, acessórios e comida, esses migrantes disputam o mesmo espaço com brasileiros e outros grupos de imigrantes principalmente vindos da Bolívia, da China, do Equador, da Colômbia e outros conterrâneos na procura de um sustento de vida na maior metrópole brasileira.

Os entrevistados foram contatados na mesma feirinha de madrugada localizada no Bairro do Brás e em diferentes momentos da minha visita no lugar. Foram apresentados pela primeira entrevistada Jandy, quem me aproximou não só à dinâmica da feirinha, como também ao seu próprio círculo familiar e de amizade ao me receber sempre na sua casa, tanto para acompanhar sua rotina do dia a dia como camelô na feirinha, quanto para compartilhar tardes de conversação, risos e confidências. 
Figura 1: Feirinha da madrugada do Brás

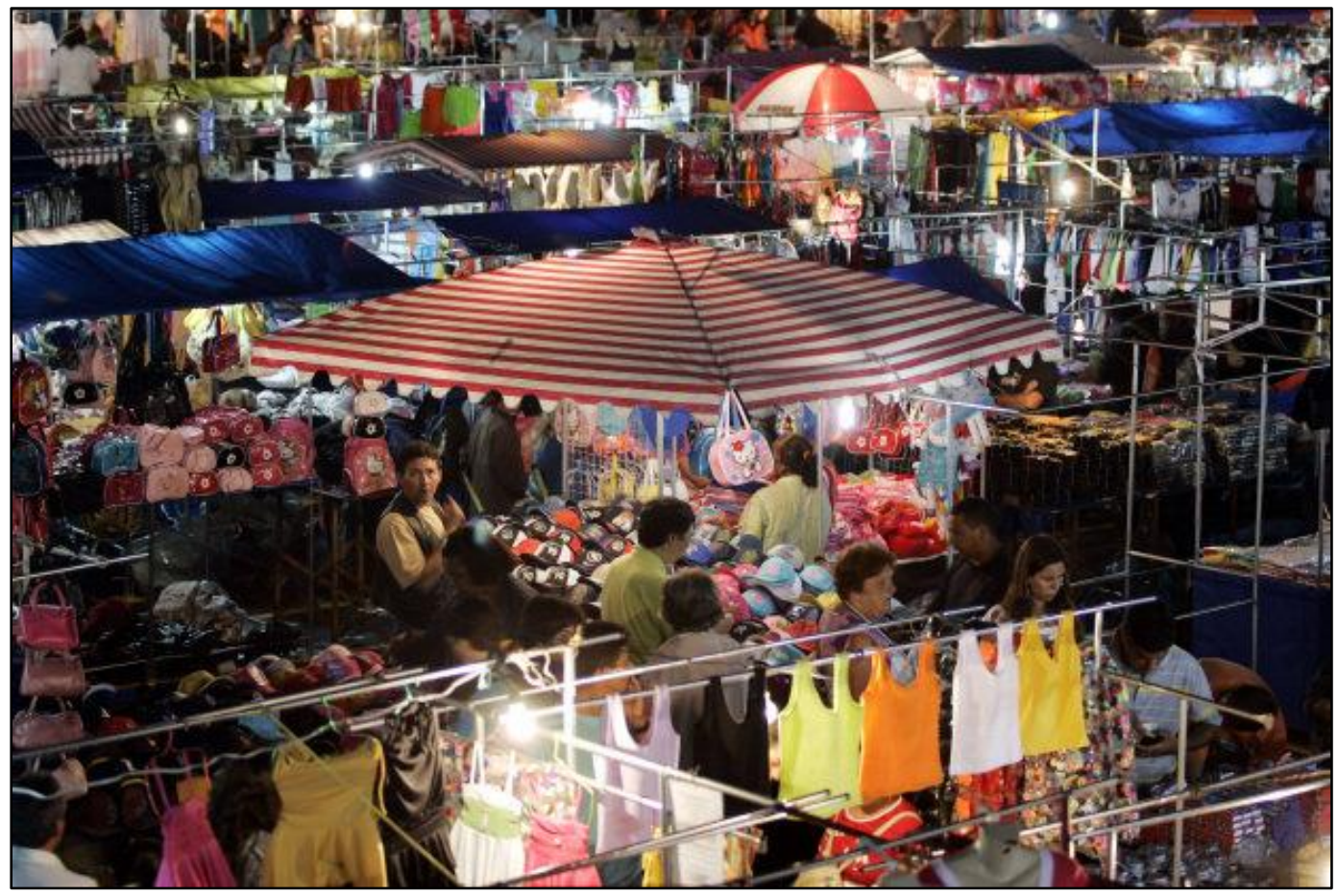

Fonte: http://www.jorbras.com.br/portal/index.php?option=com_content\&task=view\&id=3618\&Itemid=2

Figura 2: Mapa do principal ponto da Feirinha de madrugada do Brás

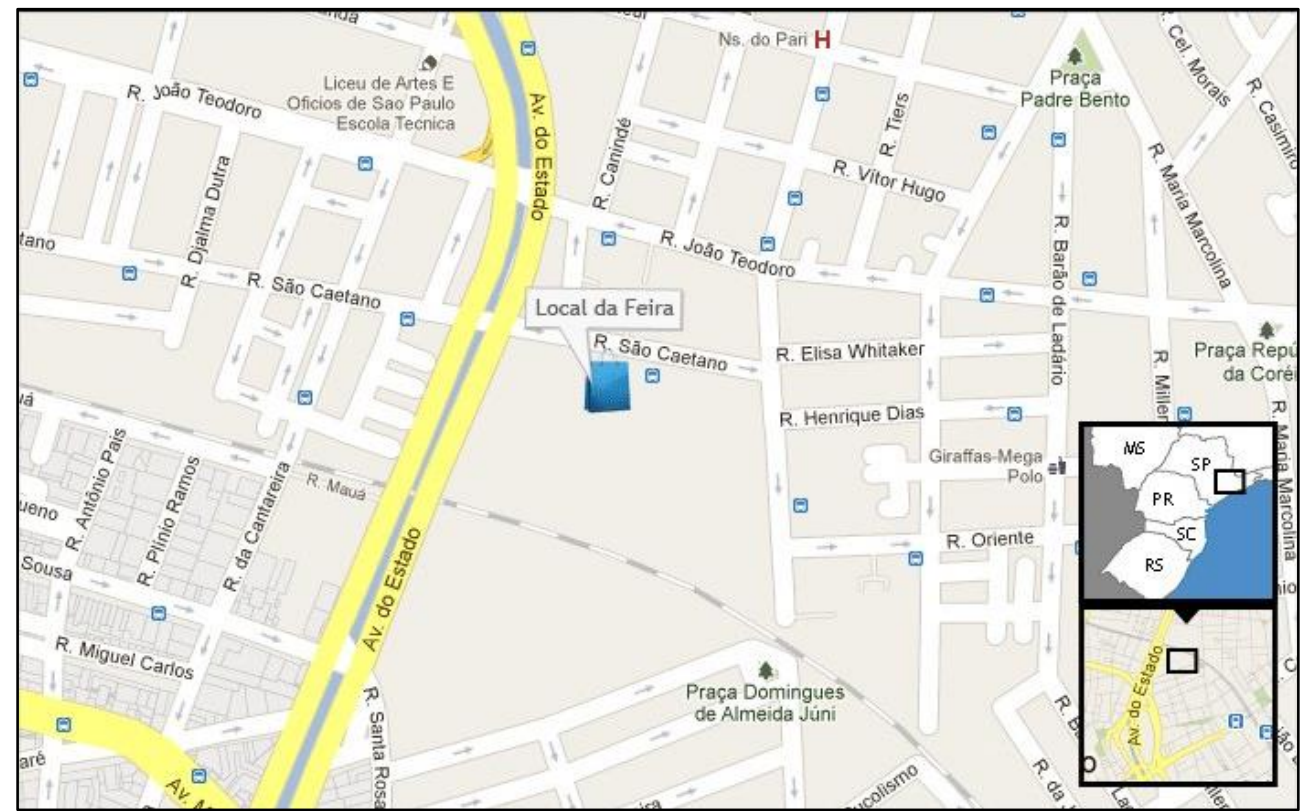

Fonte: http://noticias.r7.com/sao-paulo/noticias/protesto-por-reabertura-da-feirinha-da-madrugada-fechaavenida-do-estado-20110811.html

A feirinha de madrugada do bairro Brás faz parte dos mercados populares da cidade de São Paulo, de segunda a sexta feira, no período de duas às nove ou dez da manhã. A feirinha conta com a presença de milhares de compradores vindos de diversas 
regiões do Brasil, sendo que muitos deles chegam através de empresas de ônibus especializadas em "turismo de compras", encarregadas de realizar trajetos de ida e volta de diversas cidades até o estacionamento principal da feirinha. Este mercado de madrugada se desenvolve em grandes galpões de infinitos boxes cujo espaço não supera os três metros de cada uma dessas lojinhas. Mas a atividade principal acontece na rua, fora dos galpões, especialmente nas Ruas Oriente, São Caetano e Monsenhor de Andrade, onde uma quantidade enorme de comerciantes ambulantes se encontra comercializando diversos produtos como roupa e acessórios sendo que muita de mercadoria é produzida por eles mesmos ou então adquirida de outros maioristas.

$\mathrm{Na}$ feirinha encontram-se ambulantes das mais diversas nacionalidades, sendo predominante a presença de vendedores bolivianos, peruanos, equatorianos, paraguaios entre outros. Outros vendedores como os chineses, são proprietários de grandes lojas de bijuteria e acessórios geralmente importados da china, e nas suas lojas pode se encontrar vendedores brasileiros trabalhando para eles. Encontram-se também vendedores de comida circulando entre os galpões e as ruas levando marmitas e bebidas quentes em carrinhos, oferecendo café da manhã típicos dos seus países aos seus clientes, geralmente vendedores ambulantes conterrâneos.

A feirinha de madrugada constitui um espaço de diversas formas de sociabilização no qual se destaca uma notória divisão de grupos de vendedores dependendo da sua procedência assim como a formação de redes. Constitui ao mesmo tempo um lugar de grandes disputas, conflitos e negociações dentro do espaço, entre os comerciantes brasileiros e os comerciantes imigrantes, entre os próprios comerciantes imigrantes, entre os comerciantes e a polícia, e entre os comerciantes e grupos destinados à cobrança do aluguel e venda da via pública.

As entrevistas foram realizadas no centro da cidade, cenário principal de trabalho, moradia e lazer dos peruanos entrevistados e da maior parte dos migrantes camelôs. Duas das entrevistas foram realizadas na própria casa dos entrevistados, ambos os apartamentos alugados junto a outros peruanos comerciantes. As outras duas entrevistas levaram-se a cabo em lanchonetes indicados por eles próximos a suas moradias. Para um deles, o motivo dessa escolha foi por falta de condições para receber visitas, acrescentando que se sentiria mais a vontade em um lugar maior e público. A escolha do lugar nesses dois casos teve também algumas consequências de caráter técnico com o áudio da gravação devido ao barulho dos carros, vozes, gritos e demais interferências durante a entrevista. Em contrapartida, ao se tratar de um lugar com 
presença de muitos outros imigrantes, os entrevistados manifestaram em alguns momentos, atitudes e comentários em relação às pessoas de outras nacionalidades, tal como é o caso de Harold quem parou a entrevista em varias ocasiões para sinalar e identificar a nacionalidade de vários outros migrantes que circulavam na mesma calçada da lanchonete:

Esses são paraguaios. Os paraguaios são mais altos e mais brancos. Os bolivianos são mais gordinhos, baixinhos e um pouco mais escuros. Os equatorianos têm o cabelo comprido e são baixinhos. Os peruanos são mais diversos, altos ou baixos, se lhes reconhece melhor pelo jeito de falar, além disso o peruano é mais experto, mais vivo. Os bolivianos são mais caladinhos, se você fala com eles, eles falam, se não, não. Eles são muito desconfiados. (Harold)

Em resumo, os entrevistados foram Jandy, Harold, Cesar e Sara, os quais serão apresentados em detalhe a seguir.

\section{Jandy}

A primeira entrevistada foi Jandy, uma mulher de 53 anos que conheci no começo do ano 2015 numa visita a uma ONG destinada ao assessoramento de imigrantes em assuntos relacionados com o visto, ela se encontrava acompanhando uma amiga peruana que acabava de chegar ao país e precisava regularizar-se. No momento da entrevista Jandy trabalhava como comerciante ambulante na feirinha de madrugada do Brás, vendendo principalmente roupinha para criança. Cada dia depois das vendas da feirinha, Jandy volta para casa para costurar a mercadoria que venderá na semana, nas duas maquinas que ela adquiriu ela corta os tecidos e costura as peças para depois estampá-las. Às vezes, Jandy deixa uma parte das peças em casa de costureiros bolivianos para realizar alguma parte do processo de produção. A entrevista com Jandy foi realizada no seu apartamento na Rua Mauá, próximo á estação Luz. O imóvel era um pequeno apartamento alugado com outros comerciantes peruanos e cujos espaços estavam improvisadamente divididos com paredes de madeira com paredes improvisadas e dividido com outros peruanos comerciantes. A rua tinha presença de imigrantes aparentemente da Bolívia e do Peru, não só caminhando pela calçada, como também entrando e saindo de seus apartamentos e casas na mesma rua. 
Nasceu em San Diego, um povoado colombiano fronteira com o Peru. De mãe peruana e pai colombiano a vida de Jandy transcorre desde a infância entre estes dois países, em viagens constantes pelo rio amazonas e, devido à separação dos seus pais, sua vida fica dividida entre ambos os países, com visitas regulares aos parentes colombianos por parte de pai. Em reiteradas ocasiões Jandy afirma se sentir mais peruana do que colombiana, já que a maior parte da sua vida decorre em território peruano, a família é toda peruana e afirma conhecer mais a cultura, historia e geografia do Peru do que da Colômbia. Já na juventude, migrou para Lima, onde teve suas primeiras experiências como comerciante ambulante, ocupação que repetiria na Colômbia, na Venezuela e agora no Brasil, onde mora há três anos. Tanto na Venezuela quanto no Brasil, Jandy morou em varias ocupações de prédios e casas abandonadas, participando inclusive nas manifestações dos movimentos sociais de luta por moradia no centro de São Paulo.

Alguns meses depois de conhecer-nos, marcamos uma entrevista na sua casa na Rua Mauá, próxima à estação da Luz. Quando cheguei à sua casa, Jandy se encontrava costurando roupa de criança que venderia na madrugada seguinte na feirinha. Imediatamente reparei que estava gripada e com o rosto muito cansado, mesmo assim me recebeu muito contente e começou a mostrar-me os espaços do seu apartamento, um lugar pequeno, com habitações e cozinha improvisada, porém muito organizado. o espaço maior da casa e onde levamos a cabo a entrevista era uma sala usada como oficina de costura onde trabalhava e guardava toda sua mercadoria e suas maquinarias, as quais me mostrou com muito entusiasmo, comentando a felicidade que sentia por, finalmente, ter conseguido compra-as. Encontrava-se também na sua casa Fernando, sobrinho de Jandy recém-chegado da Colômbia e que decidiu vir morar em São Paulo para ajudar a vender a mercadoria que sua tia costurava. Inicialmente nos sentamos todos na cozinha para beber um café, comer bolo e conversar um pouco sobre o Peru, a Colômbia e da Venezuela, lugar onde viveram alguns anos atrás. Uma vez acabado o bolo, Jandy e eu voltamos na sua pequena sala de costura, onde segundo ela, se sentia mais à vontade e com maior privacidade para falar. Antes de começar a entrevista me comentou que se sentia um pouco doente dos brônquios porque o tempo começava a esfriar cada vez mais e o seu trabalho era na madrugada, momento mais frio do dia.

Contou-me também sobre uma dor muito forte que vinha sentindo nas costas devido a uma operação na vesícula. Segundo Jandy, o esforçado trabalho de comerciante de rua, costurando até altas horas da madrugada, poucas horas para dormir, 
e mercadoria pesada que carregar diariamente, lhe inflamava aquela região da operação. Eu, preocupada pelo estado da sua saúde, indiquei-lhe alguns hospitais para ela poder ser atendida, lhe falei um pouco sobre o SUS e centros públicos que atendiam especificamente a mulheres e casos de emergência. Infelizmente, Jandy, depois de dois anos na cidade não conhecia esses centros médicos, pois nunca tinha pisado um hospital em São Paulo. Com tudo, Jandy foi de muito apoio para mim, não só pela pesquisa que eu estava fazendo, mas pela disposição a me escutar e compartir sua historia comigo.

Jandy adora viajar, mencionando em reiteradas ocasiões que toda sua família tem alma cigana, tal e como afirmava sua avó. No dia que a gente se conheceu, eu lhe comentei um pouco sobre a pesquisa que estava realizando com imigrantes peruanos em São Paulo, ela se mostrou muito interessada em me ajudar. Foi assim que ficamos em contato todo esse tempo, Jandy sempre disposta a me mostrar e ensinar sobre o mundo do comercio ambulante em São Paulo. Nas visitas que eu fazia na rua 25 e o Brás ela sempre estava disposta a me levar e me apresentar seus companheiros e colegas de rua, comerciantes ambulantes como ela. Também apresentou para mim a parte da sua família que trabalhava também como comerciantes, alguns na rua, outros já em melhores condições alugando espaços nos shoppings da 25 de março.

\section{Harold}

Na minha primeira visita na feirinha de madrugada do Brás, Jandy, uma amiga vendedora ambulante que contatei a começos do ano 2015. me apresentou a vários de seus colegas comerciantes, todos peruanos, que encontravam-se vendendo na rua. Um desses vendedores era Harold, um jovem de 17 anos proveniente da cidade de Chiclayo que chegou no Brasil um ano atrás. Harold estava vendendo roupa sobre um plástico azul na pista do lado de outros jovens também vendedores, percebi um pouco de cansaço no seu olhar, porém, não era impedimento para fazer piadas e soltar risadas. Eu me apresentei, falei que era peruana também e contei para ele um pouco da minha pesquisa, Harold se mostrou interessado em me ajudar com as entrevistas. Foi assim que a gente se encontrou no dia seguinte pela tarde num lanchonete perto da sua casa, no mesmo Brás. Harold se desculpou por não ser possível fazer a entrevista na sua casa, posto que o apartamento onde ele morava era muito barulhento. Ele dividia um apartamento com outros jovens peruanos dedicados também ao comercio ambulante e 
naquela hora todos voltavam dos seus trabalhos e ficavam conversando, comendo, escutando musica e brincando. A gente, então, teve um pouco de dificuldade em encontrar um lugar adequado e com condições favoráveis para a entrevista. Aquele bairro tinha muita movimentação, muitos transeuntes e vendedores nas calçadas, muitos carros e ônibus transitando, camiões fazendo descarga de mercadoria em cada esquina, musica de todos os tipos saindo das lojas, dos carros e das casas e até crianças jogando futebol no meio da rua. Mesmo assim e, depois de andar por vários quarteirões achamos um lugar relativamente tranquilo e com poucas pessoas. Fora da lanchonete circulavam também muitos outros imigrantes entre bolivianos, equatorianos, peruanos, colombianos e paraguaios, os quais Jason conseguia identificar e diferenciar, sinalando a nacionalidade de cada um deles. Pedimos duas Guaranás, o refrigerante predileto de Harold, escolhemos uma mesa e começamos a nossa entrevista.

Um ano e meio depois, por casualidade, encontrei Harold em um jogo de futebol de peruanos em Paraisópolis. Resultou que ele era amigo dos jovens comerciantes que eu conheci na feirinha. Harold era um dos meninos que se preparava para jogar contra outros peruanos mais velhos, também comerciantes. Ele estava tranquilo, junto a sua namorada, uma menina boliviana. Parecia emocionado com o jogo, tinha sua roupa especial para futebol da seleção peruana, branca com vermelho. Infelizmente o time de Harold perdeu, mas esse não foi impedimento para dar risadas, comer a deliciosa "pollada", compartilhar com os amigos e claro, beber umas cervejas.

$\mathrm{Na}$ época da pesquisa Harold tinha 17 anos. Nasceu na cidade de Chiclayo, uma cidade ao norte do Peru. Antes da sua vinda para o Brasil, Harold estava cursando o ultimo ano do ensino médio e começando a assistir num cursinho para ingressar na universidade, morava em Chiclayo, com seu o pai, um comerciante de gado e outros produtos e cuja atividade de comercio transcorria entre varias outras cidades do norte do país. O motivo que o levou para sair da sua cidade foi a vontade de conhecer Machu Picchu, destino que nunca chegou a conhecer. Passou por outras duas cidades mais, sendo Puerto Maldonado onde decidiu ficar por um tempo ajudando o seu tio na agricultura. Nessa mesma cidade, Harold fez amizade com um jovem alguns anos mais velho quem propus viajar para o Brasil e assistir a copa do mundo. Depois de pensar por alguns dias decidiu ir embora, sua maior motivação foi o futebol, não pensou nunca chegaria a trabalhar, simplesmente o desejo dele era de conhecer e ficar um mês pela copa do mundo 
Devido a que Harold era ainda menor de idade, falsificou alguns documentos para conseguir sair do país, foi assim que, junto ao seu amigo, viajaram por Puno e Juliaca e uma vez em Bolívia atravessaram La Paz e Qochabamba, chegando alguns dias depois em São Paulo. Como Harold tinha vários tios que trabalhavam com comercio no Brás, trabalhou ajudando eles nos seus negócios por uns meses, mas depois resolveu se afastar e trabalhar por conta própria vendendo mercadoria na feirinha de madrugada no mesmo bairro. Trabalhando na feirinha, Harold deve acordar tudo dia às duas da manhã e ficar vendendo na rua até as 9 ou 10 aproximadamente.

Para Harold, a vida de um imigrante aqui é difícil já que tem que trabalhar muito para se manter na cidade, devido ao alto custo de vida, moradia, comida de São Paulo. Além das dificuldades com o ritmo de trabalho, Harold menciona em reiteradas ocasiões os conflitos entre brasileiros e estrangeiros, conflitos raciais e disputas pelo espaço público para conseguir um ponto onde trabalhar.

\section{Cesar}

Conheci a Cesar na minha primeira visita na feirinha de madrugada do Brás, onde me foi apresentado por Jandy. Era aproximadamente as 4 da manhã e eu estava acompanhando Jandy na sua banca de mercadoria. Estávamos conversando com uma jovem boliviana que estava vendendo na banca do lado quando passou um jovem arrastrando um carrinho pelo asfalto, passava vendendo comida peruana em marmitas e garrafas com Quinua e maca, uma bebida quente que agente acostuma beber no café da manhã, típico do Peru e da Bolívia. Cesar passava nas ruas gritando- "Quinua, Quinua!” e cumprimentando a seus "caseritos", geralmente peruanos e bolivianos que esperavam com ânsias sua chegada. Cesar, nome de aquele comerciante, se aproximou à banca onde eu estava com as demais mulheres e com um sorriso no rosto lhes perguntou - "Lo mismo de siempre, no?". Eu perguntei para ele o que era que estava vendendo. Ele reconheceu rapidamente meu sotaque e me respondeu "Quinua calientita! Tú tambien eres peruana, no?". Respondi que sim e falei da cidade onde eu vinha e quanto tempo levava aqui no Brasil. Pedi para ele me vender duas garrafas daquela quinua quentinha que cairia perfeita para essa madrugada fria. Devo admitir ao mesmo tempo que fiquei

\footnotetext{
${ }^{2}$ Termo usado no Peru para chamar aos clientes frequentes.
} 
muito emocionada por, depois de dois anos, poder beber aquela bebida que me lembrava tanto à minha cidade e a qual eu acostumava a beber com minha família no mercado, uma bebida que a gente consume desde crianças para crecer fuertes y sanos. Achei Cesar um rapaz muito alegre, sociável e brincalhão com todo mundo. Inclusive começou a brincar comigo sobre minha cidade, o meu sotaque próprio da minha região e brincadeiras que fazem todos os peruanos pela história e posturas separatistas que caracterizam a cidade de onde eu sou.

Algumas semanas depois daquele encontro, pedi para Jandy o contato de Cesar já que o conhecia muito bem por ser também sua cliente. Contatei Cesar e lhe contei que estava fazendo uma pesquisa sobre peruanos em São Paulo, e ele aceito me ajudar. Foi assim que combinamos para nos encontrar na quinta feira da mesma semana às 4 horas da tarde na estação república, próximo do seu trabalho e da sua casa. Era uma tarde chuvosa e caminhamos apressadamente na procura de um restaurante ou lanchonete para beber um café e conversar. Encontramos por sorte um restaurante tranquilo no segundo andar de um prédio antigo. Pedimos dois cafés e começamos a conversar.

\section{Sara}

Conheci a Sara a traves de Jandy, sua tia, também trabalhadora da feirinha de madrugada. Sara é uma jovem de 33 anos nascida em Iquitos, Amazônia peruana. Jandy me apresentou Sara numa manhã no final da feirinha de madrugada do Brás. Aquele dia foi minha primeira visita à feirinha de madrugada e estava já amanhecendo quando Jandy, sentada do lado da sua mercadoria me comentou que tinha uma sobrinha vendendo nesse mesmo momento e nessa mesma feirinha. Fiquei interessada em conhecer aquela moça e pedi a Jandy me levar onde ela estava. Sara encontrava-se vendendo roupa na calçada numa das ruas onde acontecia a feirinha. Ela estava conversando com outros jovens camelos, aparentemente peruanos também, e interrompi para me apresentar. No meio da agitação toda, própria do final de feira, falei um pouco de mim, da onde eu vinha e o que estava fazendo em São Paulo, contei um pouco da pesquisa e ela aceitou participar. Combinamos assim para realizar uma entrevista para encontrar-nos uma terça perto da sua casa, no cruze na rua Cantareira com São Caetano, perto da estação da Luz. Depois de encontrar-nos nessa rua, muito movimentada com 
presencia de bolivianos e peruanos e negócios de confecção de roupas e venda de maquinarias para costura, Sara me levou para o apartamento dos seus amigos peruanos, outros jovens camelôs como ela, já que no seu apartamento encontravam-se seus companheiros reunidos para começar a beber, por esse motivo preferiu fazer em um lugar mais tranquilo. $\mathrm{O}$ apartamento era uma espécie de republica, dividida com vários outros jovens mulheres e homens entre 18 e 25 anos, a maioria provenientes de Iquitos e outras cidades menores da Amazônia peruana. No momento da entrevista, os moradores começaram a voltar do trabalho carregando seus carrinhos, alguns vendiam mercadoria, outros trabalhavam como cabelereiros, outros vendiam sobremesas peruanas na rua. Era um ambiente muito movimentado, alegre e muito organizado, com tarefas de casa devidamente divididas entre todos.

Depois da entrevista, estávamos todos reunidos na sala contando piadas e historias engraçadas de como todos chegaram no Brasil e anedotas da vida no Peru. A maioria já conhecia vários outros estados no Brasil, onde pararam um tempo para morar e trabalhar. Falavam dos planos que tinham de viajar nas férias para alguma praia e também conhecer as Cataratas de Iguaçu no final do ano. Como todo jovem, faziam também planos para o final de semana como ir numa balada peruana de salsa e reagueton para comemorar um aniversario de alguém da turma, evento ao qual estive convidada. Recebe o convite também para assistir a uma jogada de futebol que acontece regularmente no bairro de Paraisopolis junto a outros peruanos que morar no lugar. 
CAPÍTULO 1

1. CONTEXTUALIZAÇAO DA IMIGRAÇAON PERUANA NO BRASIL 


\subsection{História da imigração no Brasil}

Historicamente no Brasil os processos de industrialização e urbanização devemse em grande parte à presença de imigrantes no país. A final do século XIX, a entrada de estrangeiros foi facilitada e promovida pelo governo através de duas medidas estratégicas: A primeira medida visava fornecer "braços" para o trabalho agrícola nas fazendas de café, substituindo assim o negro escravo pelo imigrante livre. $\mathrm{O}$ acelerado crescimento da população estava determinado então pela necessidade de introduzir mão de obra para o trabalho agrícola, em outras palavras, a entrada de imigrantes no Brasil era justificada unicamente por seu trabalho, tal como sinala Diégues (1964):

Esquece-se da pessoa humana que há no imigrante, para ver-se nele apenas o braço ou a maquina de que a lavoura necessita (...). O que se olhava, pois, no elemento estrangeiro aqui entrado, simbolizando principalmente o trabalhador branco e livre, era a maquina agrícola que ele representava (op. cit. p, 53).

A segunda medida teve o objetivo de povoar o país. Essa imigração estava constituída por homens e mulheres de origem exclusivamente europeia, sendo predominantes os imigrantes italianos, espanhóis, alemães, poloneses e holandeses, a fim de preservar o elemento branco da conformação étnica brasileira. O Brasil, desde seus primeiros momentos de república, tem elaborado políticas migratórias baseadas na exclusão e seleção de indivíduos considerados "desejáveis" para a formação do estadonação. Essas politicas não só estabeleceram perfis professionais e laborais favoráveis mão de obra qualificada- como também perfis com um determinado tipo racial. Assim, seguindo um ideal de raça branca europeia, o Brasil submeteu os habitantes a medidas extremamente racistas e segregacionistas.

$\mathrm{Na}$ América Latina, o desejo de transformar a raça esteve diretamente relacionado com a formação da "identidade nacional" uma vez que toda a região foi estereotipada negativamente pelos cientistas europeus, para quem a América Latina era "um povo tropical, atrasado e racialmente degenerado" (STEPAN, 2005. p.14). Os países europeus simbolizavam a civilização e o avanço, enquanto a as demais regiões não-europeias, como a América Latina, eram consideradas bárbaras e atrasadas. Estes, por sua vez, argumentavam que os países latino-americanos eram nações novas não consolidadas cujas identidades encontravam-se determinadas por formas raciais incoerentes: 
Para os europeus, a Argentina significava o melhor do pior da Europa, o México com sua maioria racial de índios e mestiços, afastava-os da norma branca europeia; e, finalmente o Brasil, com seu clima tropical, estimulava a miscigenação, por tanto sua deterioração racial (op. cit. p.76).

Para o sociólogo Anibal Quijano (2000), a imposição de uma classificação social racial-étnica da população do mundo é a base do que ele denomina colonialidad, um padrão de poder capitalista constituído nos últimos 500 anos com o encobrimento do não-europeu e o qual se mantem até hoje. Este padrão de poder fundiu-se com as experiências coloniais e as necessidades capitalistas, consolidando assim relações subjetivas cujo eixo principal foi uma hegemonia eurocêntrica. Neste subjetivo e hegemônico mundo ocidental, foi-se estabelecendo uma forma unificada de racionalidade, a qual fora imposta a todo o mundo não europeu, sendo uma das ideias mais difundidas a da superioridade racial.

Já desde o século XVIII, o euro-centrismo foi consolidando o mito de que a Europa significava o nível mais avançado de desenvolvimento da espécie humana, o centro do mundo, capaz de descobrir, conquistar e governar todos aqueles territórios sem conhecimento, sem história, sem cultura, como também sem nome. Foi consolidando-se, por sua vez, uma ideia de humanidade que classificava e dividia a população do mundo em dois grupos: por um lado os superiores, dominantes, racionais e civilizados europeus aos quais se atribuía a raça branca; e por outro, os inferiores, dominados, irracionais e primitivos não europeus, aos que se atribuía a raça de cor. Nas palavras de Quijano “a escala de gradação entre o branco da raça branca e cada uma das outras cores da pele, foi assumida como uma gradação entre o superior e o inferior na classificação social racial” (op. cit. pp. 374-375)

Para a historiadora Nancy Stepan, “as raças não são entidades naturais preexistentes, mas grupos sociais produzidos por relações desiguais de poder e práticas discriminatórias". Acrescenta que, devido ao esforço dos cientistas de reivindicar um conhecimento objetivo ao estudo das raças e a tentativa de ocultar os processos políticos detrás da criação das fronteiras entre cada um de estes grupos raciais, é que a ciência constituiu-se a linguagem mais poderosa de afirmação das raças como grupos naturais. 
Desde começos do século XIX acreditava-se que numa terra como o Brasil, a transformação de raça em direção ao branco seria uma questão de tempo, sobretudo, em casos de casamento entre indivíduos brancos e negros. A ideia de branqueamento incentivava a ideia de que futuras gerações poderiam livrar-se da condição de inferioridade. Segundo Rugendas, a maior ambição no negro liberto "reside na esperança de que seus descendentes possam um dia, através de uniões com raças menos escuras, integrar-se na população dos homens de cor e ter assim a possibilidade de obter empregos e dignidades".

Em 1814, um artigo publicado no Correio Braziliense propôs como solução ao problema da raça "recolher no Brasil a mais vantajosa colheita de imigração da toda parte de Europa"(HOFBAUER, 2006, p.175), citando como possíveis imigrantes alemães, holandeses, escoceses, irlandeses e americanos, e acrescenta:

Concluímos que meditando sobre a extinção da escravatura no Brasil, a Corte do Rio de Janeiro deve imediatamente tomar medidas para prover-se de artistas, agricultores e trabalhadores dos países da Europa, e que para convidá-los deve publicar leis e regulamentos saudáveis, que persuadam o mundo, que as instituições politicas do país são tão favoráveis, quanto é bom o clima, e fértil o terreno (op. cit. pp. 181-182).

Em 1880, Joaquim Nabuco fundou a Sociedade Brasileira contra a Escravidão, conformado por vários grupos que defendiam a importação de mão de obra europeia. Nabuco desde Londres escreveu vários projetos políticos e econômicos para o Brasil, influenciados no modelo industrial inglês. Nos seus escritos assegurava que a escravidão impedia a modernização e o progresso de um país e que o trabalho livre era mais econômico e mais inteligente. Para ele o verdadeiro progresso poderia ser alcançado somente a traves da imigração de mão de obra europeia. "a imigração europeia traga sem cessar para os trópicos uma corrente de sangue Caucásico vivaz, enérgico e sadio, que possamos absorver sem perigo". E acrescentava: "no futuro, só uma operação nos poderá salvar - à custa da nossa identidade nacional- isto é, transfusão do sangue puro e oxigenado de uma raça livre (op. cit. p. 197)".

O país atravessou por mudanças radicais a partir das ultima décadas do século XIX com a abolição da escravidão em 1888 começou-se a pensar em medidas para a diminuição da população escrava através de incentivos para a imigração europeia, onde os imigrantes brancos substituiriam os escravos negros nas plantações e consequentemente, acelerar o processo de industrialização nos centros urbanos do país. 
Começa assim um período de povoamento, com a abertura de fronteiras para os países de raça branca europeia, sendo a Itália, a Espanha, a Alemanha, a França, a Polônia, a suíça, entre outros, chamados a povoar o país restringindo a entrada de migrantes de países limítrofes, da Ásia e África. É assim que entre 1890 e 1920 mais de 1, 5 milhões de imigrantes brancos entraram no país. $\mathrm{O}$ acelerado crescimento econômico do pais a partir de atividades extrativas e de exportação de matéria prima como o café trouxe também uma suma de consequências que agravaram a problemática social brasileira. Para Stepan:

As consequências de tal crescimento foram devastadoras - um desenvolvimento distorcido e "dependente" cujas manifestações sociais foram pobreza, distúrbios sociais e, na maioria das vezes, crescimento em vez de decréscimo das desigualdades, especialmente para os segmentos negro e mulato da população (STEPAN, 2005, p. $33)$.

O Brasil entrou assim no século XX como uma sociedade racial e socialmente estratificada, um país governado por uma pequena elite branca e onde menos do $2 \%$ da população participava das eleições nacionais. Uma sociedade onde a maior parte da população era negra, mulata, pobre e analfabeta. Um país com grande desigualdade de oportunidades, onde uma população de quase 700 mil ex-escravos, sem direito a educação, excluídos e marginalizados, tiveram que afrontar de maneira adversa a concorrência de trabalho assalariado de mais de um milhão e meio de imigrantes brancos europeus que entraram no país como parte da política de branqueamento da nação.

As condições de pobreza e falta de saúde que afrontavam as classes mais baixas, constituída na sua maioria por negros, começou a incomodar alguns especialistas em saúde e intelectuais da elite branca, para quem os pobres "eram pobres porque eram anti-higiênicos, sujos, ignorantes e hereditariamente inadequados". O principal medo dessa elite era o perigo e violência, segundo eles, engendrados pelos negros e mulatos, os quais eram definidos como "preguiçosos, indisciplinados, doentes, ébrios e em permanente vagabundagem". Foi assim como as ideologias de limpeza e branqueamento racial através de medidas eugênicas começaram a ser uma questão de urgência dentro dos planos políticos, sociais e médicos para a conformação de uma identidade racial do país.

A partir dessa "problemática racial", é que no final do século XIX e começos do século XX pensa-se a eugenia como uma solução para a regeneração nacional no Brasil. 
A eugenia foi um movimento ideológico, cientifico e político baseado no aprimoramento da raça humana, a pureza de grupos e o melhoramento e controle da reprodução. Foi um movimento inspirado em ideias eurocêntricas de superioridade, sociedade e natureza construída pelo mundo ocidental ao longo dos séculos, submetendo o mundo às praticas racistas mais perturbadoras e inumanas.

Normalmente, o movimento eugênico é ligado a práticas nazistas alemãs da segunda guerra mundial. Isto resulta em um problema na medida em que se estaria ocultando outros períodos da história e outras regiões do mundo onde se levaram a cabo práticas e difusão das ideias eugênicas. Uma dessas regiões é América latina, a qual a pesar de ser sempre muito receptivo ás ideias e valores europeus, é deixada de lado no momento de analisar e aprofundar o período de eugenia que atravessou a região. A eugenia, então, mesmo sendo um tema tão pouco divulgado no Brasil e no resto de países da região, merece uma análise tanto histórica, quanto social e politica para o entendimento dos principais conflitos sociais no presente.

O Brasil foi o primeiro pais em estabelecer formalmente uma sociedade eugênica. Alguns eugenistas brasileiros compartilhavam o sonho de ver algum dia seu povo "transformado em puros gregos". Um paraíso helênico onde reinasse o intelecto, a beleza e a virtude, o que nos lembra de que a eugenia era basicamente um movimento preocupado com a estética e a pureza.

No final de 1917, em uma reunião de médicos da cidade de São Paulo, Renato Kehl, um jovem graduado em farmácia e medicina, apresentou pela primeira vez a Eugenia e os supostos benefícios que poderia trazer à sociedade brasileira. Em um contexto de guerras e conflito, o Brasil era o único país latino-americano a participar da primeira guerra mundial e as notícias que chegavam ao país eram de derramamento de sangue e mutilação daqueles que retornavam do campo de batalha. Era preciso pensar em regenerar as nacionalidades e eugenia foi proposta como uma boa alternativa para preservar a grandeza da nação. Na conferencia, Kehl sinalava: "a campanha eugênica é oportuna neste momento em que no Brasil se despertam as forças regeneradoras. Também o é, pelas lições que se podem tirar do terrível fator disgênico que é a guerra, esse flagelo ceifador de vidas preciosas" (DIWAN, 2007.p.96).

Dias depois daquela conferencia, Renato Kehl enviou uma circular convidando os médicos da prefeitura do estado de São Paulo para fazer parte de uma nova sociedade cientifica dedicada à eugenia. Nasceu assim em janeiro de 1918 a Sociedade Eugênica de São Paulo, primeira sociedade institucionalizada da América Latina. A sociedade 
contou com cerca de140 membros, um grupo inclusive maior que a sociedade eugênica francesa, conformada por intelectuais, médicos e membros de diversos setores sociais interessados em discutir a nacionalidade a partir das ciências biológicas e sociais.

Desde o começo a sociedade definiu-se como uma organização científica, culta e professional de produção e divulgação cientifica orientada ao fortalecimento físico e moral da raça brasileira. Estava também baseada em combater problemas sociais relacionadas à criminalidade, delinquência juvenil, prostituição e patologias considerados próprios da população mestiça e negra. Desse modo, para tornar o estado saudável foi necessário erradicar todos os resquícios da miscigenação do país, civilizando a herança indígena e branqueando a herança negra. Os eugenistas sugeriam então várias medidas para a cura do Brasil, entre elas encontrava-se o branqueamento pelo cruzamento ou "miscigenação construtiva", a regulação dos casamentos, a esterilização, o segregacionismo e o controle e restrição da imigração.

A partir de 1932, já com a institucionalização da eugenia no Brasil, o Ministério do Trabalho designou à Comissão Central Brasileira de Eugenia- CCBE, organizada por Renato Kehl e com a participação de Oliveira Viana, a pensar os problemas da imigração no país. Já desde 1925 se defendia a imigração restritiva no Brasil, inspirada na lei de imigração restritiva nos Estados Unidos, que restringia a entrada de brancos pobres e de imigrantes racialmente inferiores.

Anos mais tarde Getúlio Vargas chegou no poder, num mandato que durou até 1945. Foi interpretado por alguns críticos como uma "versão brasileira do fascismo europeu" (STEPAN, 2005. p. 173). O Estado Novo foi um estado corporativista, onde combinava elementos regressivos e progressistas. Caracterizou-se por ser um governo repressivo dos demais partidos políticos e onde o Estado assumiu com o poder para controlar sua população, especialmente dos chamados socialmente problemáticos, como as prostitutas, doentes mentais e delinquentes juvenis.

A ideia eugenista influenciou o regime Vargas no desejo de criar uma "consciência homogênea de nacionalidade como base da vida política e social" (op. cit. p. 174). A pesar das profundas diferenças sociais e raciais que caracterizavam o país, se desenvolveram mecanismos para criar uma consciência de unidade nacional, onde a fusão cultural e racial fora vista como uma solução para a conformação do patriotismo e

\footnotetext{
${ }^{3}$ A miscigenação construtiva foi uma ideia de melhoramento racial onde se argumentava que em um processo de miscigenação, as raças inferiores seriam absorvidas pelas superiores, eliminando-se a inferior e fixando a raça superior à identidade nacional.
} 
a diminuição das diferencias étnicas. Este projeto de homogeneização estabeleceu leis que restringiam o numero de estrangeiros que poderiam trabalhar em empresas brasileiras, estabeleceu o português como única língua de instrução nas escolas, suprimiu a publicação de jornais em língua estrangeira, a exibição de bandeiras de outros países e a identificação estrangeira das colônias em terras brasileiras. Inspirados por sentimentos e ideais nacionalistas excludentes, os políticos defendiam a restrição de imigrantes no Brasil como medida de proteção à população na concorrência de empregos na época da Depressão e para assegurar o processo de fusão racial e branqueamento que atravessava o país.

Eugenistas e políticos manifestavam sua preocupação com o estabelecimento de grandes grupos de colonos, os quais se recusavam a adaptar-se à língua e cultura brasileira. O ideal de brasilianização deveria ser protegido de ameaças externas, especialmente de grupos nacionais cujas diferenças fenotípicas e culturais, poderiam perturbar o processo de homogeneização do país. Por outro lado, nesse período teve uma diminuição da imigração europeia e um incremento de imigrantes de origem asiática, chegando a 50 mil no ano 1929. Esse declínio de imigrantes europeus começou a preocupar aos eugenistas até que em 1933 a CCBE promulga a Lei de Restrição à Imigração.

Influenciada pela ideologia nazifascista e pelas políticas imigratórias norte americanas, a lei afetou a entrada no país de asiáticos e judeus, denominados pelos eugenistas como não-assimiláveis socialmente. As observações de Miguel Couto acusaram aos japoneses de criarem um mosaico racial no país. Por outro lado, Antônio Carlos Pacheco e Silva argumentaram com supostos dados que os imigrantes japoneses e italianos haviam trazido novas doenças para o Brasil e assegurou que a restrição migratória era também uma medida de saúde pública.

De uma postura de boas vindas para imigrantes brancos, Brasil começou a fechar as portas aos imigrantes em nome da proteção dos nacionais através de uma política de nacionalização da mão de obra, tendo como resultado uma diminuição significativa da população estrangeira e um consequente aumento de imigração interna principalmente do Nordeste à capital paulista. (PAIVA, 2004). Seguindo um modelo integrador do regímen Vargas e ao considerar as colônias estrangeiras como elementos desestabilizadores da segurança nacional, é que se implementaram severas restrições de entrada aos estrangeiros que estabelecia cotas, assim como a comprovação econômica e outros testes para medir a adequação das pessoas ingressantes no país. 
Com tudo, as imigrações para o Brasil no transcurso do século XX caracterizaram-se por ter fluxos migratórios com perfil e dinâmicas muito heterogêneas, porém, sempre determinadas por bases politicas e econômicas. As políticas migratórias desenvolvidas em todo esse período estiveram diretamente relacionadas com a captação de mão de obra de trabalhadores, sendo o estado de São de Paulo o principal polo de atração. Os imigrantes vindos ao Brasil até as primeiras décadas do século $\mathrm{XX}$, foram na sua maioria agricultores vindos da Europa ocidental e do Japão para trabalhar nas plantações de café, em quanto os perfis dos imigrantes chegados nas décadas entre os anos 1950 e 1970 foram principalmente trabalhadores urbanos como operários industriais nas fabricas e na construção civil.

\subsection{A nova cara da imigração para o Brasil}

A surpresa nas últimas décadas do século $\mathrm{XX}$ tem sido a chegada de novos imigrantes para o Brasil. A imigração para o pais se modificou rotundamente a partir da década de 1970 com a aparição de novas ondas migratórias procedentes de países da América Latina, África e parte de Ásia, sendo os hispano-americanos quem representam a face mais visível dessa mudança, especialmente nos grandes centros urbanos como São Paulo. A partir dos anos 1980 o perfil dos imigrantes chegados no pais tem principalmente um componente de origem laboral, (SILVA, 2008) onde bolivianos, peruanos, equatorianos, colombianos e outros imigrantes de origem andina, são inseridos em trabalhos de manufatura, serviços, trabalhos domésticos e comercio ambulatório.

A chegada ao país de imigrantes latino-americanos também despertou preconceitos e formas de discriminação há muito tempo existentes no país contra indígenas, usualmente associados á ignorância e á pobreza. Do mesmo modo, os migrantes são também motivo de preconceito e atitudes racista e xenófoba por parte dos brasileiros, cujo imaginário de invasores é reforçado constantemente pela mídia através da reprodução de imagens negativas sobre eles.

O Brasil, além de ser um destino de grandes oportunidades de trabalho no imaginário desses imigrantes, representa também um lugar de oportunidades educativas para os jovens interessados em fazer cursos de especialização, graduação e pósgraduação nas universidades públicas brasileiras devido à gratuidade e à possibilidade 
de obter uma bolsa de estudos, fato impensável no país de origem da maioria dos jovens latino-americanos.

Para Silva, para os imigrantes latino-americanos mais jovens o Brasil simboliza um lugar de grandes oportunidades, embora a quantidade de dificuldades atravessadas por eles na sua chegada ao país como a exploração da sua mão de obra nas oficinas de costura no caso dos bolivianos, nos restaurantes no caso dos peruanos, problemas relacionados com a documentação, a dinâmica exaustiva de trabalho a discriminação racial existente a imigrantes com raízes indígenas, entre outras.

\subsubsection{A imigração peruana em São Paulo}

No estudo demográfico de Baeninger, Peres e Demetrio (2014) sobre o perfil sociodemográfico da imigração peruana na Região Metropolitana de São Paulo e do Interior de São Paulo, tentou-se entender a situação e caracterização desse grupo migratório na região paulista. A primeira fase da imigração peruana começaria na década dos anos 1950 a partir de acordos bilaterais entre ambos os países, fazendo possível a chegada de centos de estudantes peruanos com o motivo de realizar estudos de graduação e pós-graduação nas universidades brasileiras.

Décadas depois, e a raiz da profunda crise econômica nos países da América Latina, principalmente por motivos de reestruturação politica e econômica a partir dos anos 1980 contingentes de peruanos com outro perfil começaram a migrar para o Brasil, motivados na maioria das vezes pela violência politica que atravessava o país e pela falta de emprego e oportunidades devido à crise econômica da época, o que se agravaria na década dos anos 1990 com a implementação de medidas de precarização de trabalho e de direitos no governo de Fujimori.

O censo demográfico do ano 2010 mostra que até esse ano, 4.875 pessoas nascidas no Peru encontram-se entre a Região Metropolitana de São Paulo e no interior paulista, concentrando a maior quantidade dessa população na capital. As cidades de procedência desses imigrantes são Lima, capital do país, Arequipa, Cusco, Callao, La Libertad, Cajamarca, Lambayeque, Ayacucho e Junin (op. cit. p.3).

Até o ano 2000 o perfil dos peruanos ingressantes no Brasil estava caracterizado por ser homens e mulheres jovens, entre os 18 e 35 anos, solteiros e de escolaridade médio. Já no ano 2010 observa-se uma mudança no perfil respeito à idade, sendo esta 
mais envelhecida, entre 20 e 54 anos. Por outro lado, existe também diferença entre o gênero dos peruanos ingressantes no país, sendo a capital paulista onde se encontram mais homens e no interior de São Paulo as mulheres.

Essa diferenciação de gênero e espacialização esta estreitamente relacionada à atividade económica. Os imigrantes homens com menos de três anos de permanência no país realizam trabalhos independentes, sendo os empregos com carteira assinada uma segunda opção. A taxa de mulheres com emprego não remunerado na capital paulista é considerável, a diferencia das peruanas residentes no interior do estado que trabalham com carteira assinada e em alguns os casos como empregadoras. A atividade dos peruanos é diversa, porém, destacam-se os trabalhos na rama do comercio, venda e costura, assim como cozinheiros, babás e diaristas.

A captação de trabalhadores desde o país de origem é bastante comum entre este grupo migratório, a qual é realizada por empregadores conterrâneos e direcionando a mão de obra para setores específicos do mercado no Brasil. Para os autores, a atividade comercial desempenhada pelos peruanos é a produção e circulação de mercadorias, assim como a presença significativa de peruanos no ramo da cozinha devido aos restaurantes de comida peruana situados na região central do Centro de São Paulo.

\subsection{Contexto histórico social do Peru contemporâneo}

O Peru é um país situado na região oeste da América do Sul. Segundo dados do Instituto Nacional de Estadística e Informática (INEI) a população do país é de 31 milhões, 488 mil 625 pessoas até 30 de junho no ano $2016^{4}$ sendo o quinto país mais povoado de América do Sul. O Peru está dividido em 24 departamentos e uma província constitucional, todos eles criados no nascimento da República em 1821. Está dividido também em três regiões naturais, onde o 55, 9\% da população vive na Costa ou Litoral e cuja capital, Lima, alberga 9 milhões de pessoas; um 29,6\% na Serra ou Andes e uma menor parte da população com 14,5\% na Amazônia.

\footnotetext{
4 https://www.inei.gob.pe/prensa/noticias/el-peru-tiene-una-poblacion-de-31-millones-488-mil-625habitantes-9196/
} 
Figura 3: Mapa da divisão política do Peru

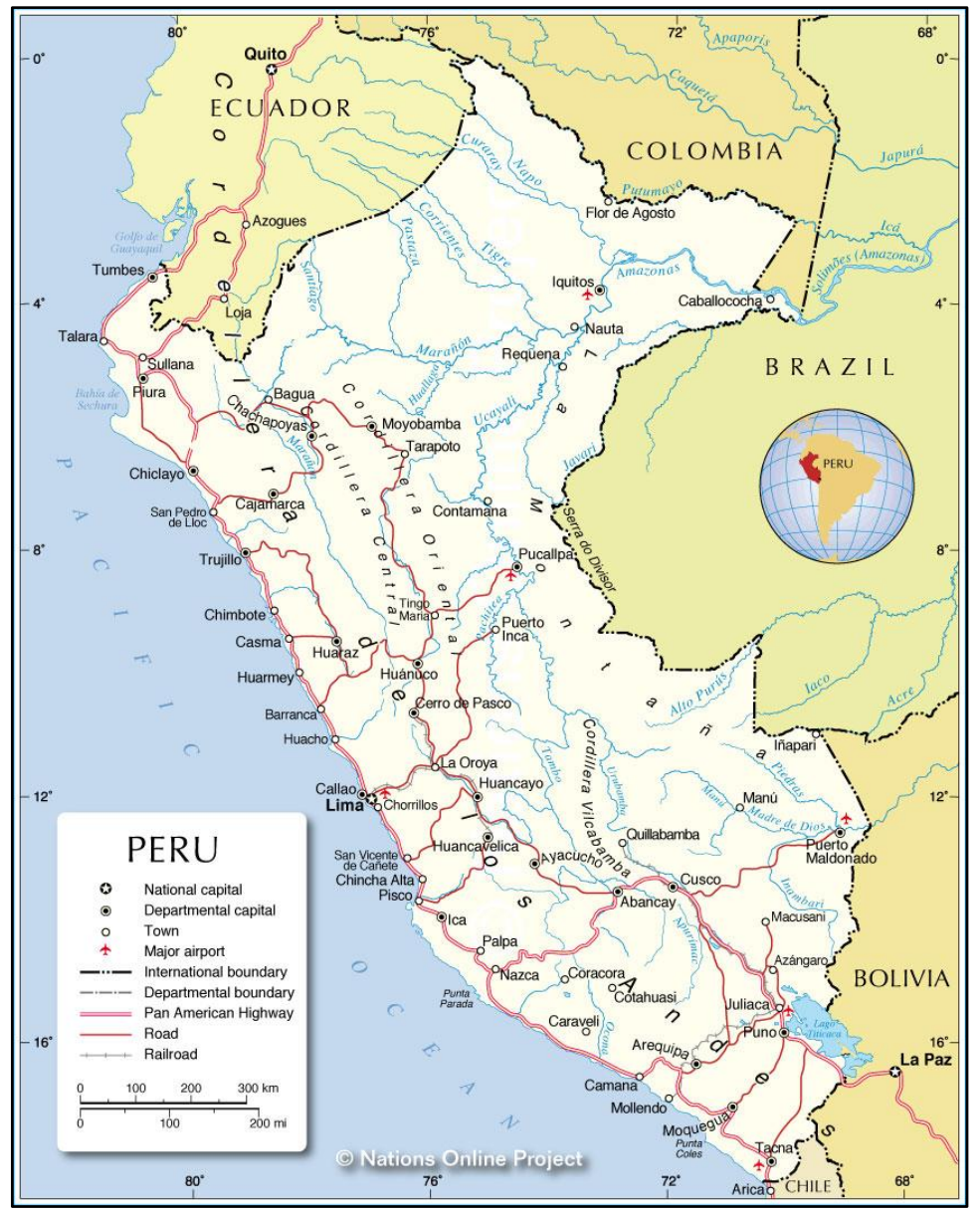

Fonte: https://infographicsandinfographics.files.wordpress.com/2011/06/mapapoliticodeperu1.jpg.

Para desenvolver uma contextualização histórica-social do Peru contemporâneo analisam-se alguns eventos de grande relevância histórica que modificaram e reconfiguraram a sociedade e estrutura do país. O primeiro evento que considero relevante são as grandes migrações e deslocamentos internos das regiões andinas à capital. Em segundo lugar considero o período do conflito armado interno entre as décadas 1980 e 2000 e finalmente as reformas econômicas neoliberais implementadas no Peru a partir dos anos 1990.

Primeiramente, não é possível entender o Peru atual sem olhar às migrações e deslocamentos internos que começaram significativamente há mais de 50 anos com a chegada dos camponeses na cidade. A migração do campo à cidade constitui na América Latina um dos fenômenos mais complexos e dinâmicos que perfilam a natureza das sociedades causando um acelerado processo de urbanização pela chegada de imigrantes provenientes das áreas rurais até os centros urbanos do país. 
O Peru, como a maioria dos países da região, encaixa perfeitamente com esse padrão. O país iniciou desde o ano 1940 uma verdadeira explosão demográfica devido a diversos fatores como a redução da taxa de mortalidade infantil, a alta taxa de nascimentos, o controle das principais doenças infectocontagiosas e a construção de sistemas adequados de agua e esgoto. Esse rápido incremento populacional coincidiu com um crescimento das áreas urbanas devido a uma migração massiva desde o campo até as cidades e, ao mesmo tempo dos Andes até o litoral. Esse êxodo rural originou-se por um desequilíbrio e desigualdade a nível econômico e social entre o campo e a cidade expressado no baixo nível de vida das populações do interior pela falta de acesso a bons sistemas de saúde; a impossibilidade de acesso à terra, a qual representava um meio essencial de produção e a exploração dominante que caracterizava as relações de trabalho rural. Por outro lado, a agricultura começou a travessar fases críticas originadas pela incapacidade de competir com a crescente importação de alimentos produto dos avanços no transporte marítimo, vendo-se afetados diretamente os camponeses, com a demissão massiva de trabalhadores rurais nas fazendas tradicionais nos Andes e na agroindústria no litoral.

O litoral, em especial Lima constituiu um poderoso íman de atração para os povoadores andinos, para quem a capital foi - e continua sendo- sinônimo de esperança, trabalho remunerado, possibilidades de ascensão social e oportunidade de participação na vida urbana a nível social, cultural e política. Esses fluxos migratórios alteraram substancialmente a configuração tradicional da sociedade a nível demográfico, econômico, cultural e social do país.

A crescente urbanização das grandes cidades junto ao êxodo rural, foram moldando o Peru, convertendo-o num país predominantemente urbano, cuja sociedade caracterizava-se pela total desigualdade expressada no rechaço e negação de direitos aos povoadores andinos, excluindo-os de oportunidades de participação social, política e econômica do país. Para compreender essa situação de exclusão e negação dos andinos consideram-se relevantes as palavras de Golte (2001), para quem a população indígenacampesina do Peru tem sido historicamente submetida a relações de exploração, repressão e exclusão por mais de cinco séculos junto a ideologias de modernização e mestiçagem integrador.

A sociedade peruana, ao longo da historia, tem se desenvolvido num sistema bi cultural. O primeiro grupo era composto pelos criollos ou cultura mestiça predominantemente urbana e burocrática com origens mediterrâneas e que representava 
o polo moderno, ocidental e dominante representada como uma cultura nacional y global. E por outro lado, o grupo dos índios ou cultura indígena e dependente com origens pré-hispânicas, cuja forma de produção e conhecimento era basicamente andina, a qual representava o atraso e o obstáculo para o desenvolvimento.

A supremacia criolla dominava e controlava todas as terras e indústria mineradora, sometendo às comunidades camponesas, especificamente quéchuas e aymaras a diversas formas de dependência, tanto pessoal como econômica. Mas esse sistema de domínio e subordinação a qual limitava a comunicação das classes camponesas com o resto do mundo se viu fortemente afetado a partir das grandes ondas migratórias do campo à cidade a começos do século XX. A imigração andina para cidade deixou por descoberto que aquele modelo social herdado da época colonial não incluía os camponeses nos seus esquemas de produção.

Para Golte (2001), o incremento significativo da imigração para cidade se originou porque o Estado não permitia o desenvolvimento da capacidade de produção de acorde às necessidades existentes dos povoadores rurais. Aquele sistema colonial praticado pelo Estado originava um crescimento econômico inadequado e desigual no país, favorecendo os criollos e prejudicando e excluindo os camponeses. Aliás, os programas do governo de assistência social e desenvolvimento dirigido aos habitantes rurais estavam dirigidos para que os camponeses progredissem nas suas terras, afastados do mundo urbano, negando-lhes assim o direito à cidade. "esperava-se que a civilização chegasse no campo, não que os camponeses viessem a procura-la (DE SOTO, 1987, p.11). No Peru, já desde meados do século XX, tiveram propostas de projetos para restringir os direitos e negar a cidadania aos andinos, tais como a proibição da construção de apartamentos baratos em Lima, um projeto de lei para proibir a entrada de andinos na capital, ou um projeto para a criação de passaporte para todos os provincianos que quiserem entrar na capital.

Já desde a década dos anos sessenta, começava-se a analisar o fenômeno pelo qual atravessavam os andinos na sua chegada à cidade chamado de cholificacion (BOURRICAUD,1970). A cholificacion é um conceito sociológico que faz referencia ao processo através do qual o migrante andino incorpora-se na cidade, originando uma mudança nas suas relações num ambiente que não sente como seu, criando um constante estado de contradição e angustia existencial referente às necessidades básicas de trabalho, comida e moradia. Essa contradição era plasmada na sua conduta, na maneira 
de encarar a adversidade numa sociedade hostil e na reconversão dos seus códigos culturais.

Para Golte (2001), os movimentos migratórios do campo à cidade não significaram uma ruptura desses grupos com suas redes sociais do lugar de origem, senão sua re-territorialização. "Onde chegavam os imigrantes, recriavam em associações formais e informais a coesão de grupos que compartilhavam a mesma origem e organizavam a inter-relação com seus parentes e conterrâneos nas aldeias". (op. cit. p, 115). Essa reformulação de território significou também a ruptura com a dependência à qual foram submetidos ao longo da história por parte da classe dominante.

Atualmente três quartos da população do país vivem em áreas urbanas onde incide o crescimento econômico e que concentram a indústria e atividades empresariais e de comercio. Fala-se de uma litoralização da população já que as cidades mais povoadas encontram-se no litoral do país. Cidades que ao mesmo tempo desenvolvem aceleradamente agroindústria e que demandam mão de obra, geralmente vinda das regiões dos Andes e de pequenas cidades. A região dos Andes por ser principalmente provedora de mão de obra, teve sua população diminuída em comparação ao litoral e a Amazônia. Essa ultima região, também atravessa transformações preocupantes devido ao desenvolvimento da indústria e ao crescente desmatamento pela execução de projetos de exploração de madeira, extração de hidrocarbonetos e minerais.

Outro fato histórico relevante foi a extrema violência politica no período compreendido entre os anos 1980 e 2000, e que comprometeu no mínimo dois terços do território nacional. O conflito teve seu inicio em maio de 1980 na cidade de Ayacucho com a denominada "guerra popular" por parte do Partido Comunista del Peru, Sendero Luminoso, movimento conformado principalmente por professores e estudantes universitários e de escolas rurais com o objetivo de declarar uma guerra ao estado peruano (SANDOVAL, 2002).

A partir desse momento, cenas cotidianas de assassinatos e massacres, execuções extrajudiciais, desaparições forçadas, sequestros, torturas, tratos cruéis e inumanos e violência sexual contra mulheres e crianças marcaram com sangue e violência o cotidiano do país. A violência politica foi desencadeada pelos grupos subversivos Sendero Luminoso (SL) e o Movimiento Revolucionario Tupac Amaru (MRTA) e pelas forças militares e policiais. Dados corroboram que foram os agentes do estado peruano, representado pelas Forças Armadas (FFAA) e forças policiais que 
agiram com maior violência através de medidas de repressão e crueldade dando lugar a um terrorismo de estado. Assim, segundo o informe 55 da Defensoria del Pueblo, os principais agentes da violência política foram os membros das Forças Armadas com uma porcentagem de $74,14 \%$ de crimes e atentados aos direitos humanos, seguidos de um 13,36\% das Forças policiais e, em menor medida, os grupos subversivos como Sendero Luminoso com um 3,02\% através de atos de recrutamento (AGUIRRE, 2013)

No conflito existiu claramente um componente étnico, racial e cultural. Calculase que dos 70 mil peruanos assassinados ou desaparecidos, o $75 \%$ foram indígenas quéchua-falantes e aymaras conformados por camponeses da região andina e comunidades nativas da Amazônia central, sendo as zonas mais afetadas Ayacucho, Apurimac, Huancavelica, Ucayali, Junin e Lima.

Tanto os grupos subversivos quanto as Forças Armadas basearam suas estratégias repressivas sobre a base da discriminação racista entre indivíduos do litoral e dos Andes, entre os urbanos e os camponeses. E por debaixo dessa distinção étnica está a ausência do exercício de cidadania plena (op. cit. p.10).

Assim, as vítimas da violência política foram povoadores das zonas altiplánicas e da cordilheira central que afrontaram uma dupla vulnerabilidade, primeiramente pela situação de pobreza e exclusão social, economia e política da região da qual provinham, principalmente as regiões alto-andinas do Peru, e segundo pelo abuso do poder em mãos dos movimentos subversivos e das forças armadas.

Segundo dados da Comissão da Verdade e Reconciliação (CVR), meio milhão de peruanos, pelo temor de serem vítimas diretas da violência, deixaram seu lugar de origem na procura de refúgio como única opção de sobrevivência. O único jeito de permanecer fora do conflito foi fugindo da zona, com o altíssimo custo da perda de suas terras, das suas relações comunais e de bens materiais. Caso contrário, as famílias teriam que aceitar a militarização da sua vida cotidiana. Na maioria dos casos, as famílias que moravam no lugar de conflito estavam obrigadas a escolher entre se unir ao exercito ou ao movimento subversivo:

Para ambos os casos, os povoadores cíveis deviam apoia-los para ganhar a guerra, se não obedeciam ou se negavam a colaborar eram considerados inimigos e se lhes despojava dos seus direitos, convertendo-se em sujeitos de torturas, desaparições, ajustiçamentos, violência sexual, entre outros (ESPINOZA, 2007:4). 
A violência sexual das mulheres foi usada, no caso do conflito, como uma arma de guerra contra os homens que se resistiam a apoiar a algum dos grupos armados, tanto a Sendero Luminoso quanto aos militares. Como medida repressora e estratégia militar, o Estado peruano levou a cabo milhares de violações sexuais contra esposas, filhas, irmãs e demais mulheres da comunidade nos casos que os homens resistiam a colaborarem com eles. Para o autor, "em contexto de conflito, a violência sexual é uma pratica mantida e justificada pela crença de que o corpo da mulher é um território de ocupação e botim de guerra" (op. cit. p.10). A partir dessa lógica de guerra, e levando em conta que as comunidades camponesas onde se desencadeou o conflito respondem historicamente a um sistema patriarcal caracterizado pelo controle e domínio das mulheres, é que os militares fizeram uso do corpo das mulheres como chantagem e vingança aos maridos e pais, através de abusos sexuais de maneira pública e entre vários outros homens:

À violência perpetradas contra a mulher resistente da comunidade somou-se à violência sexual contra seu corpo e o das filhas. Elas sofreram de assédio sexual constante, foram obrigadas a tirar a roupa de maneira publica e sofreram de estupro por múltiplos perpetradores, presenciaram o estupro das suas filhas e viveram uma inimaginável gama de violência dirigida a seus corpo e psiques. A mulher teve que assumir o custo de ficar na sua comunidade rodeada de agressores externos à comunidade, vizinhos vigiantes, cruéis e despiedados, que ostentavam um poder absoluto sobre sua vida, seu corpo e o seu futuro (op. cit. p11).

Assim, no caso do conflito Armado no Peru, a violência sexual que sofreram as mulheres das comunidades consideradas como "inimigas" do Estado, foi antes de tudo uma estratégia militar em forma de tortura, uma medida política do Estado cujo objetivo era de desintegrar as comunidades camponesas como uma organização social. O resultado foi uma série de danos às populações andinas ocasionadas pelo dano psicológico gerado às mulheres, filhos, familiares e demais. Muitas dessas mulheres tiveram que abandonar suas comunidades fugindo para a capital, lugar onde também sofreriam outras formas de violência como maus-tratos, exploração, discriminação e racismo. Elas ficaram impedidas de voltar para seus povoados de origem por temor e desconfiança de vivenciar novamente a violência, assim como o estigma dentro de suas comunidades pelo fato de ter sido estuprada. A raiz desse evento de violência, a ideia de mulher como um objeto ficou fortalecida nas comunidades, reforçando atitudes violentas dos homens com as mulheres assim como uma postura de submissão delas, em 
uma sociedade onde a mulher desempenha um papel de vítima. Todos esses elementos, somados à desigualdade de oportunidades e de toma de decisões entre homens e mulheres, deteriorou a autoestima e a posição social da mulher camponesa peruana.

As consequências das duas décadas de violência não foram somente o numero de mortos e desaparecidos. O resultado quantitativamente maior de violência com sequelas extremadamente complexas foi o deslocamento e o traslado forçoso de populações que trouxe consequências a nível social, econômico, cultural e psicológico, que geraram danos à comunidade, como a desintegração familiar, pobreza, precárias condições de sobrevivência, marginalização, discriminação, entre outros.

O deslocamento também afetou profundamente as famílias, modificando as dinâmicas e espaços familiares. Podem-se identificar duas situações de desintegração familiar. A primeira, quando o deslocamento implica a morte ou a desaparecimento de um ou mais membros da família, geralmente o pai, ou quando os membros se separam em momentos diferentes. A desintegração aqui pode ser definitiva como consequência da morte de um ou ambos os pais; temporal quando os membros da família se deslocam separados o em momentos distintos; ou sazonal, quando um ou ambos os pais se deslocam ao território de origem na época de cultivo ou colheita das suas terras. A segunda causa de desintegração familiar é quando as famílias deslocadas chegam a cidades completamente diferentes, produzindo-se um grande choque social e cultural, impossibilitando a adaptação e inserção ao novo lugar. Na maioria dos casos acontece pelo desconhecimento do castelhano, pela discriminação racial e étnica nas capitais das províncias, sobretudo em Lima onde os andinos são chamados de "índios serranos".

Por outro lado, devido à profunda crise econômica que o país atravessava, mesmo as cidades desenvolvidas como Lima não conseguiram satisfazer as necessidades dos milhares de deslocados que chegavam diariamente na cidade. Essas zonas ocupadas pelos migrantes, localizadas na periferia da capital, se caracterizaram pela superpopulação do espaço, infraestrutura inadequada, serviços básicos deficientes e em muitos casos, pobreza absoluta.

Milhares de famílias, provenientes na sua maioria dos Andes, tiveram que afrontar um cenário urbano construído sob as discriminações econômicas, e sociais que correspondem a uma categorização étnica herdada desde a época colonial peruana, na qual tem uma diferenciação entre o mundo dos brancos e o submundo dos índios, chamados pejorativamente de cholos, ou serranos. Além de afrontar a discriminação étnica e racial, os deslocados tiveram que afrontar a discriminação política, a qual teve 
maior relevância os primeiros anos do conflito. Os deslocados dessas zonas eram sinalados como suspeitosos de terrorismos ou comumente chamados de serranos terrucos.

O deslocamento das vítimas para cidades maiores os posicionou nas zonas mais baixas e excluídas da escala social, com condições de competência laboral precária e vulneráveis à discriminação étnica e cultural. Isto gerou, na maioria dos casos, que os deslocados passassem da pobreza à pobreza absoluta. Devido a que no lugar de origem os deslocados só tinham experiência no campo agropecuário ou no artesanato, se viram muito limitados ao chegar à cidade, por causa das demandas próprias do contexto urbano onde, para conseguir subsistir, tiveram que realizar atividades para as quais não estavam qualificados, sendo muito altos os índices de exploração e subemprego. Foi assim como a maior parte dos deslocados tiveram como único recurso o setor informal, posicionando-se também marginalmente nesse mesmo setor. Segundo Coral (1994), as ocupações mais comuns praticadas pelos migrantes foram o comércio ambulante, o trabalhado em construção, e empregada doméstica. Aliás, registraram-se muitos casos onde as empregadas domésticas realizavam seu trabalho só em troca de um prato de comida ou hospedagem temporário, levando muitas vezes ao maltrato físico e moral.

No meio desse contexto de extrema violência, cresceu também o desejo dos peruanos de alcançar a paz e tranquilidade pública a qualquer custo, o que levaria a milhares de peruanos a tolerar e inclusive apoiar as medidas políticas e econômicas mais drásticas dos últimos tempos, uma grande população disposta a suspender um número importante dos seus direitos e a sacrificar suas condições econômicas em troca de superar a situação de violência excepcional que se vivia no país.

Essas medidas tiveram seu início com o autogolpe de estado o 5 de abril de 1992 sobre o mandato do ex-presidente Alberto Fujimori, onde anunciou a dissolução do Congresso da Republica com o apoio das Forças Armadas. No dia seguinte do autogolpe, o Ministro de Economia e Finanças, Hurtado Miller, anunciou a implementação de uma serie de reformas econômicas extremadamente neoliberais, através de um modelo econômico radical conhecido como Fujishock, uma das mais drásticas da historia da América Latina.

O novo regime econômico foi plasmado na Constituição de 1993 onde, segundo o Art. 63, se consagra uma "igualdade de trato" entre o capital nacional e o estrangeiro. Essa medida de livre mercado consagrava a abertura sem restrições do investimento estrangeiro, entregando o mercado interno livre de impostos e suprimindo leis 
tributarias e ambientais a toda empresa estrangeira com interesse em investir no país. Por sua vez, o governo impôs a privatização das empresas estatais mais rentáveis e, ao mesmo tempo, outorgou muitos privilégios às Forças Armadas. Fujimori também instaurou um discurso antidemocrático onde pregava a ideia de um estado antipartido, deslegitimando aos partidos sociais e impondo a ideia de um "partido da nação".

O novo modelo propiciou um crescimento econômico beneficiando só os estratos mais altos da economia, como os investidores e empresários, acabando com os direitos laborais. Tal modelo diminuiu a capacidade arrecadadora do Estado, aprofundou as desigualdades no país, centralizando as riquezas e desenvolvimento só na capital metropolitana e deixando na pobreza os estratos mais vulneráveis da população como os setores rurais. Por outro lado, a implementação sistemática do autoritarismo e a excepcionalidade atualmente praticados levaram a uma deterioração dos movimentos sociais e toda manifestação politica do povo, sendo duramente reprimida com a desculpa de que por detrás de todo protesto se encontrada a subversão encarnada pelo Sendero Luminoso, o nacionalismo humanista e atualmente a Patria Roja e o Movadef. (PEDRAGLIO, 2014)

Esse estado de desigualdade, pobreza, marginalização e exclusão foi suscitando um estado de desconforto na população mais afetada, a quem o Estado e a sociedade lhes nega a voz e participação no âmbito político, social e econômico, gerando assim inumeráveis conflitos sociais que frequentemente desencadeiam em episódios de violência aberta. O chamado conflito social que o país vem experimentando há décadas tem como principais causas as necessidades e demandas insatisfeitas, a limitada participação na política dos povoadores das regiões mais ignoradas do país e a falta de mecanismos para uma distribuição equitativa dos recursos, colocam em evidência a incapacidade do estado em implementar políticas que promovam a inclusão e igualdade para o desenvolvimento do país.

Segundo estudos recentes sobre mapeamento de conflitos no país, os conflitos sócio-ambientais são os mais frequentes, sendo a mineração uma das atividades que originam maior tensão social. A atividade extrativista de grande escala no Peru tem se incrementado na medida em que os preços dos minerais no mercado exterior aumentaram, fazendo com que as principais empresas mineradoras do mundo direcionem seus interesses aos países da América Latina, por ser uma região com abundante reserva em mineral e abundante mão de obra barata para o trabalho industrial 
e extrativista. Isto levou a implementação de inúmeros projetos de extração minera nos povoados mais recônditos da região.

No Peru existem muitas comunidades que rejeitam totalmente a prática extrativa de minerais no seu território por serem comunidades dedicadas exclusivamente a atividades agropecuárias como forma de sustento e tradição, nesses casos, as diferentes ideais de "desenvolvimento" encontram-se confrontadas: Por um lado o Estado e a empresa privada que defendem e promovem o crescimento econômico dentro da lógica capitalista e ignorando o fator social e cultural das sociedades rurais, e por o outro, encontram-se as sociedades camponesas e indígenas, para quem a agricultura significa não só uma forma de sustento, mas também uma forma de vida. "Perder um pedaço de terra para essas comunidades significa também, perder laços de parentesco, reciprocidades e demais construções simbólicas ao redor da terra" (TANAKA, ZARATE, HUBER, 2011:23). É comum que as organizações sociais involucradas em conflitos não consigam suficiente força e organização para plantear pedidos viáveis, formular demandas ou levar a cabo negociações com o adversário. Essa falta de um ambiente propício para o diálogo, junto á imposição dos planos do Estado e as ambições econômicas sem freio da empresa privada originaram medidas drásticas por parte do povo na tentativa de ser ouvido.

\subsubsection{Peru: país de emigração}

O sociólogo peruano Altamirano (2000), através de um estudo sobre a emigração peruana desde a última metade do século $\mathrm{XX}$ até a atualidade, identifica cinco fases do processo de emigração da comunidade peruana a diversas partes do mundo, sendo os principais destinos os Estados Unidos, América Latina, países de Europa Ocidental e o Japão.

A primeira fase de emigração compreende as décadas dos anos 1910 e 1920, e se caracterizou por ser uma emigração da oligarquia, isto é, jovens de famílias ricas saiam do país por motivos de estudo, poder e prestigio e se dirigiam a universidades da Europa. Quase um ritual de passagem de todo jovem da classe alta. Por outro lado, um numero considerável de peruanos viajou para os Estados Unidos para incorporar-se como mão de obra na indústria têxtil Americana cujas subsidiarias estavam instaladas no Peru explorando os desenhos peruanos e a lã de alpaca. 
O próximo período, compreendido entre os anos 1950 e 1960 os padrões de imigração a nível mundial mudaram devido à reconstrução europeia pós-guerra. O Peru passou de um país de imigrantes a emigrantes, sendo agora o principal destino os Estados Unidos devido ao crescimento econômico desse país. A partir daí, os Estados Unidos se converteriam no país com maior imigração peruana no mundo, seguido da Europa.

A fase seguinte corresponde ao governo militar da década dos anos 1970, cujas medidas socialistas como a reforma agraria e a nacionalização da banca e da indústria mineradora causaram um grande descontento na população de classe média alta e dos grandes empresários, provocando sua saído do país. Da mesma maneira com os, professionais liberais e medianos empresários, os quais emigraram para os Estados Unidos. Por outro lado, a apertura diplomática e comercial com países do bloco comunista propiciou a emigração de muitos estudantes para esses países.

A quarta fase corresponde, de 1980 até 1992, corresponde ao período da violência politica no país e paralelamente começa a maior crise econômica com o governo de Alan Garcia. Milhares de peruanos começam a migrar tanto pela violência quanto pelo empobrecimento do país, falta de emprego, hiperinflação, entre outros. Os Estados Unidos, principal polo atrator, já contava com quase meio milhão de peruanos na época. Segundo dados do Ministério de Relaciones Exteriores, o ano 1989 foi o ano de maior emigração até a época, sendo quase 100.000 os peruanos que deixaram o país para diversos destinos.

A última fase corresponde aos anos 1992 até a época nos quais, devido às drásticas reformas de direitos, entre elas as reformas econômicas e laborais no governo de Fujimori, a imigração continuo seu rumo. Até o ano 1992 aproximadamente 2 milhões de peruanos encontravam-se morando no exterior, sendo o numero dos retornos muito menor do que o numero total de emigrantes. 
CAPITULO 2

2. PERCURSOS DE IMIGRAÇÃO 
As narrativas dos imigrantes estão carregadas de imagens e paisagens da sua própria história, de seus sonhos, crenças, maneira de ver o mundo e de relacionar-se com os outros. Carregadas dos seus receios e tristezas. Os relatos de cada entrevistado estão também impregnados de lembranças da infância e juventude, das vivencias com suas famílias as quais englobam alegrias, separações, deslocamentos, saudades e claro, esperanças de volver a reencontrar seus seres queridos.

Todo imigrante carrega em si mesmo sua própria historia, historia que se manifesta a traves de seus sonhos, suas crenças, sua maneira de se relacionar com os outros, seus medos e tristezas. A narrativa de cada um dos entrevistados esta carregada de lembranças da infância e juventude, de vivencias familiares que incluem alegrias, separações, deslocamentos, saudades e claro, esperanças de reencontrar seus seres queridos. Eles expressam também a traves dos seus testemunhos, relatos sobre suas comunidades e relação com sua terra de origem, assim como os sentimentos que giram entorno aos lugares e espaços que marcaram de modos diferentes suas memoria e seus afetos.

A imigração como um fato social, é um processo que começa não só com a materialização da viagem e a chegada do migrante no pais de destino; esse processo esta determinado pela condição dos sujeitos no seus lugares de origem, por sus vivencias e pelos motivos que engendraram a saída do país, pelas dificuldades nas esferas pessoal, familiar, social e económica e, geralmente, a decisão de partir não é fácil, posto que implica primeiramente a separação e distanciamento dos imigrantes com seus seres queridos e com a sua comunidade, tendo como maior justificativa a procura de uma melhor qualidade de vida, seja a traves do trabalho ou do estudo.

A parte inicial das narrativas dos quatro imigrantes que colaboraram com a pesquisa, carregam elementos importantes do percurso da sua experiência migratória, elementos que partem das suas vivencias na terra natal, tendo como questão principal as vivencias familiares, os inconvenientes e limitações afrontados no Peru e que motivaram em grande medida a saída do país, as expectativas sobre o Brasil e os fatores que determinaram a eleição de São Paulo como destino migratório, a experiência da viagem que é na maioria dos casos uma grande aventura, a perspectiva atual da sociedade brasileira, e como é que eles se sentem atualmente, assim como as perspectiva de retorno e sonhos. 


\subsection{Narrativas dos e das imigrantes}

\subsubsection{Jandy}

\section{"Minha vó dizia que todos nós temos alma cigana"}

Meu nome é Jandy, ou Yanyi em português (risos). Tenho atualmente 53 anos. Eu nasci na Colômbia, num povoado no departamento do Cesar em San Diego, mas praticamente me criei e eduquei no Peru. Minha mãe é peruana, de San Martin e meu pai é colombiano. Tenho quatro irmãos, todos peruanos, só eu que nasci na Colômbia. Meu pai trabalhava em umas minas de carbono lá na cidade onde eu nasci, na fronteira com o Peru. Mas ele tinha ido para Iquitos nas férias com uns amigos e assim conheceu a minha mãe. Ele vinha muito para Peru a ver minha mae e ficaram um bom tempo vivendo juntos em Iquitos até que minha mae engravidou de mim e foi para Colômbia, para a cidade onde ele trabalhava e foi lá onde eu nasci, só eu, eu sou a única filha dessa relação. Depois de um tempo meus pais se separaram e ele voltou para Colômbia, não teve uma outra família. Eu tenho poucas lembranças do meu pai porque eu era criança quando ele morreu. Com 5 anos de idade, minha mãe me levou para o Peru, mas dai meu pai me levou para Colômbia de volta com 8 anos de idade e fiquei por lá mais um ano e nesse tempo foi que ele morreu, de um acidente de transito ele morreu. Dai eu fui no Peru para morar e não voltei mais na Colômbia, até os 23 anos. Eu me sinto mais do Peru. Na Colômbia eu ia mais como passeio. Eu vivi mais com minha família no Peru, com meus parentes colombianos eu fiquei pouco tempo, mas eu gosto muito deles.

Eu me eduquei no Peru com minha mãe porque é professora, professora rural, e ela nos levava a todos na escola onde ensinava. E assim eu me criei no campo, na natureza, eu gosto muito desse meio. E parece que aquele era meu habitat, os rios, o campo, as tardes na beira do rio Amazonas. Só íamos para a cidade nas férias, quando minha mãe se capacitava. Terminavam nossas férias e a gente voltava ao campo para estudar. Me eduquei toda a primaria com minha mãe no interior, mas na secundaria eu fui na cidade para estudar e assim eu fui embora para Iquitos. Depois de terminar meus estudos, todos fomos para Lima, e assim minha família morou na capital por varias décadas. Mas eu, com 23 anos fui para Colômbia porque tinha família por parte do meu pai por lá. 
Eu tenho viajado muito, desde menina. Na verdade, eu viajava constantemente pra lá desde muito menina. Também fiz alguns anos a secundaria lá na Colômbia e depois voltava para o Peru. Quando tive 14 anos fui para a cidade onde meu pai viveu, fui para ver meus tios, meus irmãos. Um irmão foi para Peru a me pegar e levar para Colômbia. Essas viagens a gente fazia por terra ou então a gente ia para Leticia e lá pegávamos um avião para Bogotá e dai ia por terra para San Diego. Eu tenho viajado muito, bastante. Eu ia de férias para ver meus parentes e eles sempre me ajudavam e recebiam. Ai, quando eu chegava na Colômbia sempre passeava muito, ficava com a família de lá tão linda, eles gostam muito de mim. Inclusive agora quando vou eles dizem “porque vai embora? Não vá embora! Se você acaba de chegar!” Fiquei algum tempo com meus parentes na Colômbia, mas depois voltei para Lima porque minha mãe já morava lá. Minha mãe tinha sua casa, meus irmãos já tinham seus companheiros, famílias. Mas eu, como tinha uma vida de ir e vir nunca pensei em ter uma família, eu me acostumei à liberdade, a ser independente. Até agora eu não gosto depender de ninguém.

No Peru eu tenho viajado bastante também. Fui para Ayacucho, Arequipa, Huancayo, Pucallpa, Tingo Maria. E olha só, eu viajei de Iquitos para Pucallpa de balsa também, mas foi um pouco chato porque a noite a balsa não avança, fica quieta e os pernilongos e mosquitos não deixam dormir. E é uma viagem muito longa, como cinco dias viajando. Mas foi essa minha experiência porque eu disse "quero conhecer os lugares de balsa". E não gostei. É bonito conhecer povoados, você vai conhecendo. Ver como as pessoas compram em quantidade peixe que vendem no rio. E em todos esses povoados a balsa fica lotada com as pessoas que vão embarcando a lo longo do rio. Eu tinha 22 anos quando fiz essa viagem pelo Amazonas, viajei sozinha! Eu dizia “eu vou!” e eu ia. Inclusive para a capital, eu morava em outro lado, mas ia para Lima. Eu levava e trazia mercadoria para vender, levava coisas para vender por lá.

Para mim é muito normal ir e vir de um lugar para outro, tenho me acostumado com isso e eu gosto. Não sei, eu tenho um espirito assim... eu fico entediada de tempo em tempo e digo "não, eu vou embora, não gosto mais daqui, não gosto". E vou embora, é simples. Eu vejo fácil ir de um lado para outro, assim é quando uma se acostuma a viajar. Na minha família todos somos assim, toda minha família viaja muito. Minha avó também era assim, ela ia para Lima e dizia - "eu vou lá para morrer" - Porque era ela velinha. Ela ficava um tempo lá e depois dizia - “eu vou embora para 
Juajuy" - Porque tinha outra filha lá, “vou morrer lá melhor”, dizia. Então ela também gostava muito de viajar. Ela dizia que todos nós tínhamos alma cigana.

Eu me sinto mais do Peru. Eu sei mais a historia do Peru do que da Colômbia. Eu me eduquei mais no Peru, na Colômbia eu ia mais como passeio. Eu vivi mais com minha família no Peru, com meus parentes colombianos eu fiquei pouco tempo mas eu gosto muito deles. Tem outra coisa, nunca ninguém soube que eu era colombiana, tampouco nunca falei que era de lá, até porque meu sotaque é da Amazônia peruana porque como eu cresci em Iquitos peguei o sotaque da região, então falava como "charapa". No Peru eu dizia que era de Iquitos e ninguém reparava que eu era colombiana. E veja, eu nunca memorizei o meu numero de DNI colombiano (risos). Cada vez que saia da Colômbia, na fronteira me perguntavam meu numero de DNI, e eu nunca sabia, nunca lembrava a funcionaria me diz "a senhora mora muito tempo no Peru, certo?" e me carimbavam (risos). No Peru eu tinha visto de estudante, eu estudei e trabalhei tudo esse tempo com visto de estudante.

Enfim, depois da Colômbia eu decidi ir para Venezuela porque também tinha família por lá, fiquei oito anos nesse pais. Eu nunca tive visto nem documentos na Venezuela, mesmo assim consegui trabalhar e morar lá tudo esse tempo. Naquela época tirar o visto na Venezuela era muito difícil. Então os oito anos que morei lá foi de ilegal. Quando eu já estava de saída daquele país começaram a facilitar a documentação.

Mas meu passaporte colombiano estava vencido e você sabe que na Venezuela não era permitido pegar o visto do teu país no consulado de lá. Então você tinha que voltar para seu país para resolver o problema do seu passaporte. Era um problema, eu tinha que sair para entrar novamente, então por isso fiquei ilegal tudo esse tempo. Mas nunca tive problemas com essa situação porque todos achavam que eu era venezuelana, olha só (risos). Era por meu físico, meus traços e minha aparência. Porque os peruanos são... os peruanos são muito diferentes a mim, então todos achavam que eu era venezuelana. Minha irmã também é branca de olhos verdes, as pessoas acham que ela é gaúcha, porque os gaúchos são assim brancos olhos verdes como ela, então pensavam que era da Venezuela.

E assim fiquei todo esse tempo morando lá. Eu sai da Venezuela quando começou a empiorar a situação econômica de lá. eu cheguei na Venezuela quando o presidente Chavez ainda estava vivo, mas depois dele as coisas começaram a piorar. Eu sai de lá quando Maduro estava no poder. A crise já vinha paulatinamente, o pais 
vinha caindo. A gente fazia filas para tudo! Até para comprar roupa. Eu pensava "não, aqui não tem mais futuro"--. Por exemplo, não tinha mais tecido para costurar os panos de mesa para as festas. Já ninguém podia vender mais de cinco metros de tecido de uma mesma cor e para o pouco que você podia comprar tinha que fazer filas longas. Então não da para trabalhar assim. Eu já sabia o que vinha, pensava "não, isto vai ficar pior”. Quando eu começava a ver as filas que tinham para comprar coisas pensei que não dava para mais, que ia piorar. Eram as eleições de prefeito, governador e eu dizia às pessoas "anda a votar, vota para que o país tenha uma mudança" e as pessoas me diziam "votar? para que se a gente esta bem assim". Ou então diziam "eu não entro na politica”. Ou seja, respostas de pessoas que não tem conhecimento do que é um governante, se eles querem votam e se não, não votam. Então eu pensei “não, isto não vai mudar". Tudo isso estava acontecendo em dezembro e eu fui embora em janeiro do 2014.

"Meu sonho sempre foi vir para o Brasil"

Desde a Venezuela eu já estava decidida a vir para o Brasil, eu queria vir direto desde lá, mas ao mesmo tempo eu queria muito ver minha família na Colômbia, por isso fiquei lá quatro meses. Nesse tempo eu fiquei trabalhando muito numa oficina de costura, mas fiquei muito doente assim que voltei para o Peru onde estava minha mãe fiquei três meses lá para ver minha mãe. Mas daí eu pensei - “o que vou fazer aqui? quero ir para o Brasil". Brasil era meu sonho, sempre foi meu sonho vir para o Brasil. A ideia que tinha do Brasil era de um país assim... Brasil. Sempre ouvi falar do Rio de Janeiro, que tinha muito turismo. Eu sempre ouvi falar dessa cidade, sempre pensei que essa cidade devia ser muito linda.

Bem, antes de ir para Venezuela eu já queria vir para cá, sempre eu dizia "vou embora a morar no Brasil, eu quero ir para lá”, mas eu não conhecia ninguém, então como podia vir assim? Na Venezuela eu sempre tentei conhecer alguém que conheça o Brasil para que me conte como era. Eu perguntava as pessoas, eu não sabia por aonde chegar desde a Venezuela, que caminho seguir até o Brasil. Então eu perguntava às pessoas - "amigo, qual o lugar que limita com o Brasil? Onde que fica a fronteira?"- E olha só, ninguém sabia! Eles começavam a perguntar entre eles - "com qual país que limite pelo sul? e pelo norte?”- E ninguém sabia! Ninguém tinha ideia! Imagina! 
Nenhum venezuelano sabia nada! Nem suas fronteiras. Em fim, naquela época minha irmã vendia Herbalife em Lima, mas na Venezuela essa marca era muito mais barata, então eu lhe enviava desde lá a mercadoria para seu negocio em Lima. Em Caracas cheguei um dia na loja Herbalife e vi uns rapaces falando uma língua estranha. Eu fiquei curiosa então me aproximei a eles, eu lhes perguntei - "de onde vocês são?”. Eles me responderam - “a gente é do Brasil”- E eu fiquei surpresa e perguntei para eles se moravam em Caracas e me disseram que estavam só de passada comprando Herbalife. Nossa, era uma quantidade gigante a que eles estavam levando de produtos para o Brasil, milhões de investimento e toda essa mercadoria já estava vendida lá. Então eu perguntei para eles qual foi o caminho que eles seguiram até aqui, aí eles me explicaram - "veja, você tem que ir daqui até cidade Bolívar, daí você pega um ônibus até Santa Helena, que é a fronteira com o Brasil”. Um deles morava nessa cidade fronteiriça com a mãe deles que tinha um hotel, e o outro morava em Boa Vista. Foi assim como fiquei sabendo por onde vir para o Brasil, e eu estava decidida a vir por aí.

Meus sobrinhos que estavam morando lá em Caracas queriam vir também para o Brasil, eu indiquei o caminho e falei para se adiantar porque eu devia passar antes na Colômbia por causa da documentação, nesse tempo minha mãe estava aqui em São Paulo visitando meu irmão e eu comentei para ela que queria ir para lá, então ela me diz “venha! Quando você vai vir?” e eu respondi “em janeiro mãe!”. Então eu vendi todas minhas coisas, todas! Meus sobrinhos também venderam tudo, tudo o que tinham para vir. E assim eu pensei - "agora sim, agora sim vou embora". E veja só, tudo se deu para eu vir, tem um dito que disse "o tempo de deus é perfeito", pode ser que deus quis eu ficasse na Venezuela um tempo porque tal vez eu tinha uma missão por lá. Então, eu fui para Colômbia a pegar meu passaporte digital, aquele novo. Daí eu fui para o Peru onde fiquei três meses e depois vim para cá. Aqui em São Paulo eu cheguei o seis de junho de 2014.

“Eu gosto das grandes cidades... em um povoado você vê só atraso”

Eu tinha um amigo colombiano que estava morando em Minas Gerais, eles sempre me convidavam a ir nessa cidade. Eu queria muito vir para o Brasil, mas não queria ir para Minas Eu sempre dizia para ele, "mas porque você não vá para São Paulo? Minas é uma cidade pequena!” E ele me dizia “sim, as vezes eu vou para lá, 
mas eu tenho meu negocio aqui em Minas gerais". Ele tinha um negocio de celulares que trazia do Paraguai. Aliás, quando eu conheci uns rapaces brasileiros eu perguntei para eles como que era São Paulo. Nessa época eu ainda não tinha ninguém aqui, meu irmão ainda não tinha chegado. Eles me disseram que São Paulo era uma cidade muito grande, que a cidade tinha vinte milhões de habitantes. Eu pensei "nossa! Deve ser uma cidade gigante!" E assim, eu vim sabendo que esta era uma cidade muito grande e assim eu gosto, eu gosto daqui. Eu não gosto dos povoados, eu gosto das grandes cidades porque eu penso que uma cidade grande tem mais oportunidades de trabalho, de todo né. Tem mais cultura. Eu gosto da historia, da cultura. Para mim esta cidade é linda, tem uns prédios belíssimos. As construções são melhores do que no Peru. Por exemplo esse Mercadão, que linda construção! Tão grande! Esse teatro municipal também. E assim, essa cidade tem umas construções lindas, prédios belos e antigos aí no centro. Minha cidade Iquitos, por exemplo para mim é um povoado, ficou muito pequeno para mim.

Meus primos me dizem para eu ir trabalhar e morar lá, montar minha oficina de costura por lá (risos). Eu respondo para ele que não gosto dos lugares pequenos, gosto das cidades grandes. Gosto de ver as pessoas, a moda, ver o mundo evoluir. Pelo contrario num povoado você vê o atraso, vê um lugar perdido esquecido do mundo. Os povoados são bonitos também, não digo que não. As pessoas são muito mais saudáveis, por exemplo no povoado onde cresci, as pessoas são muito tranquilas, eles vestem também como de povoado. Se a gente veste diferente ou leva uma tatuagem as outras pessoas acham que a gente está maluca, ou seja, é diferente. Eu lembro por exemplo que quando eu era criança, Iquitos tinha uns cavalos que levavam pessoas na parte de trás, carregavam coisas, vultos, era a única maneira de deslocar-se. Tinha pouquíssimos carros, mas só as pessoas de muito dinheiro podiam comprar. A coisa é que nesse povoado do interior onde eu nasci, continua tendo esses cavalos... imagina! (risos). Então é um lugar atrasado, tem motos, tem carros, mas continua tendo essas coisas. Veja só, a empresa onde eu costurava tem mais de vinte anos trabalhando na confecção de pijamas e os funcionários usavam tesoura para cortar os tecidos, imagina! Eles não usam nem a máquina cortadora! Sendo uma empresa que vende seus produtos nos shoppings e em grandes lojas, eles ainda trabalham daquele jeito. Como é possível que eles trabalhem assim? eles estão por fora da tecnologia e já estão acostumados a trabalhar assim. 


\section{"É o mar que tira minha tristeza e me faz sentir livre"}

Eu sinto saudade da minha família, da minha mãe, sobretudo, mas não voltaria a morar lá, eu iria só a passeio. Sinto saudade do Peru, saudade da comida. Da Colômbia, da comida também. Da Venezuela, sinceramente, nada porque nem comida eles têm. Não... a Venezuela só tem sido um ponto de trabalho, uma oportunidade a mais de chegar num país com oportunidade de trabalhar, de viver, só isso. Mas também gostei das praias da Venezuela. Eu tenho muitas fotos em varias praias que fui, tenho disfrutado muito das praias de lá. Eu adoro o mar, quando eu vou num lugar eu preciso ir no mar, preciso ver o mar, é algo que me enche de energia. Quando estava no Peru, antes de vir, me fui a ver no mar e lembro que estava fazendo muito frio. O mar me faz sentir uma espécie de liberdade, o mar me da uma energia. Eu vejo a imensidade do mar e penso que é um espaço que divide a terra e dificilmente a gente pode ter acesso, podemos só ver, é isso. Sempre foi assim, quando eu estou triste vou num rio ou no mar para ver, isso acaba com minha tristeza, me enche de outra energia. Mas em não sinto tristeza por mim, não... eu sinto tristeza as vezes mas pelos problemas dos outros. E feliz... feliz não, não posso dizer que eu sou feliz. Posso estar feliz quando estou viajando, quando estou vendo outras pessoas, quando estou conhecendo outras coisas, tudo isso me faz feliz. E me faz feliz ver minha família feliz, isso sim me faz sentir muita felicidade, saber que eles estão bem.

$$
* * *
$$

\subsubsection{Harold}

\section{“Eu sai da minha casa para conhecer Machu Picchu”}

Eu morava com meu pai lá na minha cidade, Chiclayo, antes de vir eu estava terminando a secundaria e começando um cursinho para ingressar na universidade. Um dia eu disse para meu pai: - "Pai, eu quero conhecer Machu Pichu" - Depois de insistir muito um dia aceitou que eu fosse para lá e me deu dinheiro para viajar, foi assim como saí de Chiclayo, saí só para conhecer Machu Pichu que no final nem cheguei a conhecer por ir para Puerto Maldonado. Eu cheguei só até Cusco, fiquei dois 
dias na cidade, passeei um pouco, mas dai decidi ir embora para porto Maldonado, tenho um tio que mora lá. Como a cidade esta perto de casa, pensei que podia voltar em qualquer momento. Esse corto período de tempo que fiquei nessa cidade trabalhei ajudando meu tio nos seus cultivos. Ele tem chacras, fazendas e eu o ajudava. Pouco tempo depois conheci um rapaz por lá que virou meu amigo, ficamos bons amigos. Ele me diz um dia - "vamos para o Brasil! vamos ver a copa do mundo! a gente fica por lá um par de meses e logo depois voltamos" - Então eu pensei por alguns dias e depois decidi ir embora. Minha principal motivação foi o futebol. Eu não pensei em trabalhar, queria conhecer e mais nada, eu ia ficar só um mês, só pela copa. Então eu falei um dia com meu pai e disse para ele - Painho, vou embora para o Brasil. E eu não podia ainda viajar porque era menor de idade, mas mesmo assim fiz toda a documentação e consegui viajar. No meu passaporte apareço com um ano adiantado, ou seja, que eu já fiz 18 anos em maio do ano passado segundo meu passaporte e meu DNI. Já com 18 anos é possível passar a fronteira, então peguei meus documentos e vim pela Bolívia. Com meu amigo fomos primeiro para Puno, atravessamos Juliaca e assim chegamos na Bolívia. A gente ficou um dia em cada lugar, um dia em La Paz, outro dia em Qochabamba, e assim vim conhecendo vários lugares pouco a pouco. Depois chegamos no Brasil.

Eu cheguei direto em São Paulo, cheguei como às 8 da noite e desci perto duma ponte com muito lixo, eu estava coma mala muito grande. Na ponte, assim que eu cheguei, tinha uns malucos que começaram a pedir-me dinheiro - um real! Um real! eles pediam. Meu amigo me disse então para ir na sua casa que ficava na volta da esquina. Chegamos na casa do meu amigo e esse dia descansamos e dormimos, no outro dia a gente passeou um pouco pelo bairro, pelo centro, Brás, republica. Fisicamente, achei a cidade um pouco suja, não gostei muito no começo.

Lá no Peru todos falam que o Brasil é outra coisa, todos pensamos que é outro mundo, que é incrível. Eu achava que o Brasil era como na televisão. Bom, eu já conheço o Rio de Janeiro, tenho muitas fotos do Rio no meu celular. Acho que lá é outro mundo, né? Será porque eu não moro lá? Porque uma coisa é morar e outra visitar. Mas eu acho que preferiria o Rio do que aqui. na verdade, para mim o Brasil esta igual do que o Peru. Mas em muitas outras coisas Brasil é melhor. Lá no Peru por exemplo, há quanto tempo esta se construindo o metro e até agora não o terminaram? aqui tem tudo, é outra coisa, sei lá. O comercio em São Paulo é como em Gamarra, tudo mundo chega lá, de todos os lugares. Mas acho que agora esta um pouco 
complicado, a moeda aqui caiou muito. Antes os peruanos enviavam mais dinheiro para lá. Aqui o dólar esta mais caro que no Peru. Meus amigos enviavam dinheiro para suas famílias ou investiam em alguma coisa lá, mas agora esta complicado enviar grana, quase nem conseguem enviar.

Eu acho que a maioria de peruanos vimos sozinhos, sobretudo os mais jovens. Os que fazem um filho já tem que ficar aqui, fazem dois, três filhos. Aqui os peruanos conhecem a seus companheiros que geralmente são peruanos, só entre eles ficam. Porque segundo as pessoas, a brasileira anda explorando os peruanos. Se os peruanos têm grana, fica com a brasileira e em um mês ela lhe faz gastar toda a grana, "lo sangra". A brasileira sangra ao boliviano, colombiano e peruano. O paraguaio, ao contrario, quando casa com a brasileira, aí ele anda sangrando à brasileira. $\mathrm{O}$ paraguaio é mais experto, anda sangrando também às chinesas.

"o problema aqui é mais o racismo"

Aqui no Brás você vê mais bolivianos, muitos bolivianos. Dizem que tinham milhares de bolivianos aqui, tinha mais que qualquer outro país. Dizem que de cada 3 bolivianos que vão embora do Brasil, entram mais10 e alguns se legalizam com seus documentos, mas tem muitos ilegais, e isso o brasileiro não gosta, por isso que andam destruindo os negócios dos bolivianos. Mesmo assim, eu acho que o Brasil, como país, tem muita paciência né, comparando com qualquer outro país de América do Sul. Em outros lugares, quando para você pegar o visto, demoram demais! Aqui é bem mais rápido.

Acho que aqui dão mais possibilidades, né, para você trabalhar, um outro país acho que não faria isso. O problema aqui é mais o racismo. Aqui mexem até com o chinês, o brasileiro não se da bem com o chinês, imagina! Eles (brasileiros) dizem que o chinês vem tomar o dinheiro. Aqui todos os chineses andam de carro, olha só essas tremendas lojas deles, em cada quarteirão todas as lojas são deles, em quanto o brasileiro esta na rua trabalhando para eles. O boliviano também anda de carro e chegam alguns brasileiros sem dinheiro procurando trabalho.

Eu sinto que aqui no Brasil tem muito a questão racial. O boliviano e o peruano são um pouco parecidos, o paraguaio já muda o colombiano também. Aqui como que abusam muito dos bolivianos, e os peruanos odeiam ser confundidos com bolivianos. Eu sempre escuto por aí - Oi Bolívia - e os peruanos respondem - qual Bolívia seu 
filho da puta - E aí o brasileiro não entende bem e vá embora. É porque eles não entendem nada, porque se entendessem teria muita briga. $\mathrm{O}$ equatoriano também não gosto de ser confundido com boliviano. Tem equatorianos aqui, que não sei de que lugar são, eles têm o cabelo comprido. A eles sempre andam confundindo com os bolivianos.

Eu acho que aqui tem muitas pessoas racistas, como em tudo país, né. Aqui os brasileiros se acham mais do que os outros, por sorte até agora comigo nunca aconteceu nada ruim. Aqui todos são meus amigos, já me conhecem, eu sou amigável. Mas eu vejo que muitos bolivianos são maltratados, especialmente os bolivianos que vem dos andes. Os brasileiros sempre reparam no físico. Aos bolivianos sempre lhes dizem - Oi "Bolívia" - Eles vêm a parte física e os chamam de Bolívia. Tentam humilhá-los, tem algo contra os bolivianos. Mas também, o boliviano é um pouco otário no negócio. Por exemplo, um brasileiro pega uma blusa e começa a vende-la, geralmente a vende a 20 reais. O boliviano então copia aquela blusa, a confecciona e a vende por 10 reais, a metade do preço. É por isso que se arma a briga. Porque todos falam - este otário anda barateando tudo! - Então por isso é que todos compram mais aos bolivianos, compram porque eles vendem mais barato, por isso eu acho que todos estão em contra deles, mais do que com os peruanos. Mesmo assim, o boliviano não aparece muito na venda. Aqui no Brás o boliviano anda mais na costura. O peruano é mais venda, eles são mais comerciantes. O colombiano não vende, ele empresta grana. O paraguaio trabalha geralmente para os chineses e, embora os chineses sejam exploradores, o paraguaio sabe o que faz, ele anda roubando e enganando seus patrões chineses, é por isso que eles gostam de trabalhar para eles. Mas os chineses não percebem, por que se percebessem... os pegam e já era. Aqui por isso as pessoas morrem, ninguém é contra ninguém, todos morrem igual e nem se sabe.

Brasileiros também mexem com os peruanos. Por exemplo, a dois tios meus que são de Puno uma vez os chamaram de "Bolívia", achavam que eram bolivianos. E você sabe que os peruanos são um pouquinho mais falador, e pelo seu jeito de falar sempre acaba insultando à mãe do outro, ou falam qualquer coisa ofensiva para se defender, e assim se agarram e começam a brigar. Pelo contrario o boliviano não, eles ficam calado.

Até os próprios peruanos discriminam os bolivianos, aqui os peruanos são muito racistas também. Provocam os brasileiros chamando-os de "negro de merda". Eu não sei se essa atitude seja uma maneira de se defender, aqui é simplesmente assim. Os 
paraguaios se agarram com os colombianos, os colombianos com os peruanos, e sempre é assim, é normal. Mas quem sempre perde é o boliviano porque é mais quietinho. Aqui tem um lugar chamado Coimbra, esse lugar na verdade é um povoado boliviano, são duas grandes ruas onde só têm bolivianos. Lá quando ficam bêbados nas festas os finais de semana, morrem peruanos e bolivianos, mas acho que mais bolivianos. Sempre tem alguém se achando mais do que os demais. Como se diz "branco é melhor que preto", é a mesma coisa.

\section{"Quando me lembro do peru eu me pergunto: o que estou fazendo aqui?"}

Eu quero ser engenheiro, lá no Peru. Se eu pudesse, aqui também seria ótimo estudar. Nestes dias vou me matricular num curso, numa autoescola para aprender a dirigir. Agora trabalho só para mim na rua, isso é o que eu faço porque ainda tenho 17 anos, vou fazer 18 em maio e eu ainda penso estudar. Como eu ia estudar lá no Peru, pensei que seria bom aprender alguma coisa aqui também. Dai, eu não sei se voltar para o Peru e estudar alguma coisa por lá, sei lá, estou indeciso. Eu, na real, pensava estudar e mais nada. Não tinha ideia que ia chegar a ser um comerciante. Mesmo assim quero estudar e fazer mais alguma coisa, por isso digo, vou ver ate o final do ano, talvez pense em alguma coisa.

Estou com saudades do Peru. Lá eu tinha outra vida, lá eu não tinha que trabalhar tanto. Aca eu não me sinto tão bem. No peru eu tinha amigos de verdade, aqui, mesmo você encontre muitos amigos, não é a mesma coisa. Aqui você não acha

amizades. Às vezes lembro-me do Peru e me pergunto - O que estou fazendo aqui? Sei lá, como que no Peru eu me sinto melhor. Aqui eu tenho que madrugar todos os dias. Sinto falta do meu pai, dos meus amigos. Meu pai me diz que iria me visitar, ele esta agora se dedicando ao comercio de gado, ele vai e volta da selva, compra 20, 30 vacas, vai para o norte do país e as vende, ele ganha até 500 reais por vaquinha, esse já é um negocio maior.

Meu pai sempre liga para mim, a gente sempre fala, ele me pergunta se estou bem aqui, se preciso de alguma coisa, me pergunta quando voltarei como estão meus amigos. Eu minto para ele, falo que não estou sozinho, que estou aqui com meus amigos da infância. Mas não é certo, eu aqui tenho outros amigos, caras que conheci aqui, muitos nem são meus amigos, os conheço só de vista. Por isso eu digo, vou ver até final do ano, vou ver se penso em alguma coisa. Eu acho que já em dezembro vou 
embora, se em dezembro estou mais ou menos fico aqui. Depende também se o negocio vai bem, se eu estiver estudando. Eu fui embora de Chiclayo só para conhecer Machu Picchu que no final nem cheguei a conhecer.

\subsubsection{Sara}

"no interior a vida é muito dura"

Eu não tenho muitas lembranças da minha infância, acho que minha infância foi muito curta, você sabe que no interior a vida é muito difícil. Eu sou a mais nova dos meus irmãos, somos 4 mulheres e um menino. Minha mãe trabalhava no hospital e meu pai era professor. Quando eu era criança minhas duas irmãs foram embora para Lima porque queriam estudar e minha mãe foi com elas, então só ficamos em Iquitos meu irmão, meu pai e eu. Dai estudei a primaria lá e antes que termine a primaria meus pais se separaram e fui a morar com meu pai, vivi 2 anos com ele. Daí minhas irmãs me chamaram para ir a morar com elas na capital, então eu fui embora para Lima, morei com minha irmã mais velha e depois fui morar com minha mãe. Com meu pai começaram os problemas e perdi o contato com ele por muitos anos... até agora, eu não me comunico com ele, não sei nada dele. E assim... a minha infância não foi uma vivencia especial... diferente. É simplesmente uma temporada que passou... e pronto. É uma vida que eu tive e que já acabou lembro mais da minha vida na capital. Uma vez que fui embora para lima, não voltei mais na minha cidade... não voltei mais. Não tenho necessidade de voltar na cidade onde nasci... digamos porque não tenho coisas importantes lá... é por isso que nunca voltei.

Passei tudo o ensino meio em Lima, por isso é o lugar onde tenho mais lembranças. É o que todos mas lembram, né... a escola. Tenho lembranças da minha mãe, minha irmã. Problemas... muitos problemas, mas que com o passar do tempo soube resolver. Despois entre numa igreja... igreja católica onde estive 2 anos, eu assistia e participava na igreja. O que aconteceu foi que todos devíamos fazer a confirmação antes de terminar a escola, mas acabei ficando e frequentando essa igreja por mais de 2 anos... frequentava a missa, as reuniões. Da escola lembro muito das 
minhas amigas. Eu estudei numa escola perto do meu bairro, a escola era só de meninas. Lembro da bagunça que a gente fazia, das brincadeiras. A escola sempre será uma parte da vida que a gente nunca vai esquecer.

Tenho também muitas lembranças da minha família. Meu irmão mais velho trabalhava como vendedor numa galeria. A segunda irmã tem um filho e agora esta separada do esposo. Ela sempre foi mantida por minha família. A terceira irmã estudava como eu, mas parou os estudos para começar a trabalhar, então não terminou a escola. Daí ela engravidou e tem um bebe agora. Minha mãe sempre tem costurado, ela costurava roupa de caratê e vendia para um homem. Minhas irmãs começaram a ser comerciantes quando chegaram na Venezuela. Lá cada uma tinha sua oficina de costura. Uma minha irmã trabalhava numa empresa de sapatos, ela fabricava sapatos. A outra irmã trabalhava numa galeria de roupa.

Já na juventude eu não gostava da minha vida no Peru. Não sei... não estava acostumada a viver lá. Nesse tempo eu morava em Lima e eu sentia que nada era apto para mim... nem a universidade nem o trabalho, então não fazia nada. Eu comecei estudar para não trabalhar e depois não quis estudar e deixei os estudos. Nos finais de semana tinha muitas festas... sentia que nada era para mim, que nenhum trabalho era para mim. Tudo isso eu tinha na cabeça. Aí eu tive um problema muito serio e minha mãe pediu para eu ir na Venezuela onde estavam minhas irmãs, elas já moravam lá e foi assim fui embora. Fiquei lá e não voltei mais, fui só por três meses e acabei ficando 5 anos. Só depois de 3 anos que voltei para Lima de visita e daí fui na Venezuela de novo.

Eu gostei muito de lá. A vida lá é muito diferente. Como qualquer lugar, é perigoso e excitante. Tem pessoas muito boas lá. Venezuela tem também uma mistura de muitas raças... colombianos, haitianos, dominicanos... de todo. Em geral eu gostei... mas eu sou das pessoas que ficam logo entediadas dos mesmos lugares e, no meu caso, sou de tomar decisões muito aceleradas, as vezes muito exageradas. Na Venezuela eu estava com alguns problemas, eu queria ir embora daí... estava cansada, entediada demais. Eu já tinha ouvido falar daqui, então surgiu a ideia de vir para o Brasil. Tenho um amigo que já tinha vindo para cá antes, ele tem duas bancas de roupa no Brás. Um ano antes de eu vir, ele já estava aqui e me contava como funcionavam as coisas aqui, me explicava como funcionavam as vendas, as compras, o lugar onde ele vendia. Lá eu tinha muitos amigos haitianos, sabe que os haitianos estão por tudo canto, né. eles podem ir em qualquer país porque eles recebem ajuda, em todos os países eles tem um 
albergue que lhes dá comida, casa e eles vivem do seu trabalho. Isso tem em todos os países, inclusive aqui. Em fim, esses amigos haitianos me disseram que estavam pensando vir morar aqui no Brasil. um deles me diz - "a gente vai para lá, vamos para o Brasil! Vamos atravessar a fronteira daqui e descemos por lá...”. Então eu fiquei pensando na possibilidade de vir para cá. Falei com uma tia minha na Venezuela e me diz - "sim! Eu também quero ir para o Brasil!". Temos um tio que já estava aqui, eles nos receberam e assim chegamos na casa dele. Era um tio assim... que vivia loucamente, mas em fim, chegamos na casa dele. Na real, a gente veio pela Copa do Mundo, principalmente eu, eu vim pela Copa. Eu pensei - "vou para o Brasil, lá vai ter dinheiro, vou trabalhar e fazer dinheiro na Copa e depois volto para o Peru". Assim, eu vim só por uns meses e acabei ficando ate agora. Mas esse foi o motivo pelo qual eu vim.

“a viagem para o Brasil... essa grande aventura”

No final, vimos para o Brasil meu primo e eu. Nossa... essa foi uma grande aventura. A gente saiu da Venezuela por terra. Como eu estava acostumada a ir de Venezuela a Peru de ônibus achei que seria a mesmas coisas ir de Venezuela para cá. Com meu primo, saímos um dia pela fronteira, levávamos muito dinheiro porque a gente tinha vendido tudo para vir, vendi meu carro, moveis, muitas coisas e ele também. A gente saiu com 40.000 cada um. Antes disso uma senhora nos diz: "eu tenho meu filho na fronteira, ela troca dinheiro lá, tem um carro e pode dar indicações a vocês, procure-lo". A gente contato o rapaz na fronteira, nos explicou algumas coisas e nos ajudou a passar. Trocamos o dinheiro e nos deu só 650 reais, o cambio era baixo demais... a moeda venezuelana tinha baixado muito. O rapaz preocupado nos diz: "vocês querem ir até São Paulo... não vão conseguir chegar... esse dinheiro é demasiado pouco para todos os dias que são até chegar". A gente já tinha atravessado a fronteira e não dava mais para voltar. Ele deixou a gente em Boa Vista e aí pegamos um ônibus para Manaus, chegamos no dia seguinte.

Em Manaus meu primo me disse: "não! O caminho é muito longo até lá... melhor irmos de avião". Fomos ao aeroporto e as passagens estavam demasiado caras, não dava para comprar. Umas pessoas nos disseram que dava para ir de barco até Belém e daí embarcar até São Paulo. Então fomos até aquele porto e compramos as passagens de barco... lembro que era uma segunda feira. A gente não sabia falar 
português, não entendíamos nada... fui comprar as passagens e o rapaz da agencia me diz: "quarta", eu entendi quarto andar, então compramos as passagens. Passaram umas horas e perguntei ao meu primo que horas subiria, ele foi perguntar ao cara da agencia e o rapaz falou de novo: “quarta feira, hoje não". Meu primo não entendia nada e justo tinha outra pessoa que acho que falava espanhol e falou para meu primo: "aqui quarta és miercoles". Nossa... era segunda feira e a gente não tinha dinheiro para o hotel. Falei com o motorista do barco e expliquei toda a situação, ele deixou a gente dormir no barco, mas tínhamos que esperar até às 6 da tarde para poder entrar porque ainda estavam fazendo o desembarque e descarga no barco. A gente tinha muita coisa... duas malas cada um. Ficamos sentados num parque desde as 8 da manhã até às 7 da noite esperando. Daí o motorista nos autorizou entrar, eu pedi umas redes onde dormir, mas ele falou que cada um tinha que trazer sua própria rede para dormir... então tivemos que sair a comprar uma rede. Foram cinco dias viajando de barco, o Amazonas tudo praticamente. Essa viagem foi muito tranquila. No começo só que foi um pouco complicado porque a gente não entendia nada, não sabíamos a língua, mesmo assim a gente soube sobrelevar. O problema foi que chegando a Belém a gente não tinha mais dinheiro, ou seja, tínhamos sim, mas não dava para todo o caminho até São Paulo.

Nessa doidera a gente conheceu uns venezuelanos hippies, só um deles sabia falar português porque sua namorada era baiana, os outros vinham só passeando. Falei para eles - "amigos, nós não temos dinheiro, a gente ficou com muita pouca grana e aqui os hotéis estão muito caros". Eles responderam - "relaxa, se preocupe não, aqui tem lugares muito baratos para ficar". E assim, a gente se juntou a eles, e andamos e andamos com todas as malas... até chegar num hotel que eles conheciam que estava 10 reais a noite. Quando entrei nesse hotel... parecia a hotel das baratas, juro. Eu pensei “tá bom...não temos outra opção”. Nesse lugar ficamos 3 dias, nos sobrava 50 reais. A gente foi comprar as passagens e vimos que estava como 480 reais... que merda! quase o mesmo preço da passagem para o Peru. Se eu soubesse que custava tudo isso, tinha ido para Peru então. A gente ficou muito preocupada e abrimos nossas malas e começamos a vender um monte de coisas que tínhamos na mala. Começamos a vender telefones, perfumes, Dvds, coisas que minha tia tinha encomendado. Assim vendemos muita coisa e ganhamos quase 1000 reais. Comunicamo-nos com nossas famílias no Peru e pedimos uns dólares. O primeiro dia no hotel das baratas eu não consegui dormir. 
Os meninos hippies ficaram num quarto, e a gente em outro. Segundo eles nosso quarto era o melhor... nossa... que quarto hein. Esses dias a gente ficou com eles para tudo lado, eles fumavam o dia tudo, mas a gente não é desses, então nesse sentido foi um pouco chato. Com eles não gastávamos quase nada porque eles não gastavam nem em transporte... todo faziam andando, andavam muito. Depois tinham outro costume: quando as pessoas que estavam comendo num restaurante deixavam seus pratos e iam embora, eles iam e começavam a comer os restos que os clientes deixavam. No ultimo dia, a gente foi se despedir deles, o quarto parecia que tinha um incêndio. Essa mesma noite, a gente foi na rodoviária de novo para ver se podíamos comprar a passagem.

Tínhamos 450 cada um, não chegávamos a 480 que era o preço. Pedimos ao rapaz da agencia se, por favor, nos podia vender a 450 e não quis. $\mathrm{O}$ ultimo ônibus saia as 2 da manha e já era 9 da noite. Passaram algumas horas e um dos trabalhadores nos diz: "tá bom, pode ser por 450". E assim pagamos a passagem, guardamos as malas e fomos procurar comida no porto de Belém antes de ir embora. A gente jantou e tudo, e meu primo me pergunta: "quanto dinheiro você tem?". Eu respondo; "quatro reais, e você". Ele diz: "eu tenho três". Nossa... faltavam ainda três dias de viagem, porque de Belém a São Paulo são três dias. A gente já estava cansada, então não importava mais... só queríamos chegar. Eu falei - “vamos logo, não podemos ficar mais, a gente vai ficar sem coisas para vender e nossas famílias não vão enviar mais dinheiro. Alias nosso destino não é Belém... vamos logo!’”. E assim a gente foi, o primeiro dia a gente aguentou, seguramos a fome porque viajamos na parte de trás onde tinha um garrafão de agua para beber à vontade, então bebemos agua o dia tudo. Eu não descia do ônibus para nada, o único que descia era ele porque sentia muita fome. Ele me dizia - "estou morrendo de fome, não sei o que fazer" - e eu lhe respondia - "calma, não passa nada, a gente já quase chega”. Ainda faltavam dois dias. Na minha mala sobrava ainda um perfume novo, então decidimos vende-lo. Meu primo estava muito ansioso, subia e descia. Eu, pelo contrario, só queria dormir para não sentir a fome, então ficava no ônibus, não descia para nada, não queria ver as outras pessoas comendo. Numa dessas paradas meu primo subiu e me diz - "tenho comido!”. Aí ele me contou que fez o mesmo que os hippies nos ensinaram, me contou que foi num restaurante e dois meninos já iam embora da mesa, mas quando estavam perto de colocar o guardanapo acima do prato eles pediu para pegar a comida que sobrou. E assim, ele comeu um pouco e já deu para dar uma segurada. Mas eu estava aguentando como dois dias sem comer até que não aguentei mais e numa das paradas do ônibus eu desci. Ainda me 
sobrava um perfume para vender assim que cheguei na entrada de um pequeno shopping de perfumes e outras coisas. Tinha uma senhora e não lembro como eu comecei a explicar que estava vendendo um perfume, eu não entendi nada e ela tampouco, mas me perguntou quanto e eu diz para ele $15 \ldots 15$ reais. Ela me comprou na hora o perfume e com esse dinheiro compre iogurte e uma sacola de pão, a gente foi comendo o resto do caminho, já só faltava um dia para chegar. Assim, chegamos no dia seguinte. Uma funcionaria do ônibus diz: "bem-vindos a São Paulo". Eu acordei meu primo e diz para ele - "acorda! A gente já chegou em São Paulo". E ele respondeu - “que bom! Porque estou com muita fome!”. Mas eu não via a hora de quando chegávamos, nós ficamos ansiosos por chegar e parar para comer alguma coisa, mas ficamos uma, duas, três horas esperando chegar no centro, mas finalmente chegamos.

\section{"É melhor manter a distância com os brasileiros"}

A primeira semana a gente já queria ir embora, queríamos voltar para Venezuela, não estávamos gostando daqui. A gente estava sozinha, não conhecíamos nada da cidade e lá na Venezuela pelo menos estavam minhas irmãs e eu tinha apoio delas com comida, mercadoria, elas sempre estavam pendentes de mim. A gente não ficava juntas, mas eu sabia que elas estavam preocupadas por mim. Aqui, meu tio era um zero à esquerda e não conhecia ninguém.

Mesmo assim, acho tranquilo, não tenho dificuldade em morar aqui. o único problema que não gosto é ver que aqui aos bolivianos os humilham muito, eles são muito humilhados pelos brasileiros... e por qualquer um, não sei por que. As pessoas ofendem os bolivianos, os maltratam, os mandam embora. Eu guardo minha distancia com os brasileiros. Eu sou da ideia que com os brasileiros de perto, mas também de longe. Ou seja... eles não são nem tão bons nem tão ruins. Eu mantenho a distancia

com eles, você pode brincar, conversar com eles, mas... É que a maioria dos brasileiros do Brás é de outros estados do interior, então eles têm uma mentalidade muito tosca de ser, muito malandros. Os brasileiros aqui tentam ser espertinhos e sacanear com os outros... são uns covardes. Eu falo com todos os brasileiros da feirinha, mas porque estou obrigada a falar com eles, mas não gosto de nenhum deles. Eu já briguei com vários... mas prefiro tê-los do meu lado... eles são muito traiçoeiros. 
Desde que eu cheguei só uma vez fui ao Peru. Todas minhas amigas da Venezuela estão lá agora vendendo roupa ou trabalhando nas suas oficinas. Eu gostaria muito de visitar lá de novo, sinto muita saudade da minha família, da minha mãe, minha irmã. Eu considero minha família a um grupo muito pequeno e fechado, minha mãe, minha irmã e meus sobrinhos. Eu sempre fui muito distante do resto da família, não pelo que eu sou, eu sempre fui assim com eles. As famílias numerosas são sempre muito problemáticas, tem muita fofoca... que se a tia falou uma coisa, a prima outra... não! não gosto, eu prefiro manter distancia. Aqui por exemplo, também tenho família, tenho uma tia e um primo que moram daqui a 4 quarteirões, mas não os frequento muito... quanto mais distante é melhor, prefiro brigar com desconhecido que com minha própria família.

Eu aqui tenho já um grupo, uma rede de amigos. Eles por exemplo são um grupo, na minha casa são outro grupo. Eu moro só com peruanos, todos vem de diferentes lugares de lá. alguns vem de Trujillo, Chiclayo, Huancayo, Lima. São todos muito jovens, alguns tem 19 anos, outros 25 e chegaram também para trabalhar de vendedores. todos andamos juntos sempre. Saímos juntos a trabalhar, às vezes também voltamos juntos. Na minha casa tem um horário de almoço, janta, todos comemos juntos na mesma hora. Os meninos cozinham um dia, eu cozinho outro dia. Fazemos feira juntos, vamos comprar as coisas que faltam juntos. Sou eu a responsável por fazer feira, mas um deles me acompanha uma semana, na outra semana me acompanha outro.

Fazemos feira para semana toda, estamos organizados e fazemos todo juntos. Para ir na balada vamos todos juntos também, aos aniversários, ás reuniões. Quando fazemos um churrasco nos juntamos todos e chamamos a outros grupos de amigos que também moram juntos. Somos todos peruanos e já todos nos conhecemos. É que aqui tem muitos jovens que estão chegando de lá muitos, sobretudo chegam jovens... meninas mais do que meninos. Senhores também tem, mas acho que chegando sua etapa de senhores adultos decidem ir embora.

“O Peru é um país muito homofóbico... Isso me faz não querer voltar” 
O Peru... é o lugar onde nasci, né... mas tenho alguns sentimentos contraditórios sobre o Peru que me fazem não querer voltar. É um país que lamentavelmente tem tido governadores muito ruins. Peru é um país muito rico, mas infelizmente os governadores tem se dedicado a tirar toda a riqueza do país... para os pobres sobrou nada. Tem muita mediocridade lá. É também um país ainda muito conservador, a pesar de ter tantos homossexuais lá, o Peru é um dos países mais homofóbicos da América do Sul, eu acho. Lá, o $70 \%$ da população é gay, a maioria, mas todos ficam escondidos. É também um país muito machista. O Peru é muito retrograda nesse sentido. No Equador, na Colômbia, no Chile, em quase todos os países daqui já estão aceitando mais os homossexuais. No Peru ainda se resistem a aceitar, lá os arcebispados, a igreja, são conservadores demais. Aqui é muito mais tranquilo, mas aberto, sem vergonha. O que acontece é que eu agora vivo uma vida tão diferente, tanto que se as outras pessoas me aceitarem ou não, para mim tanto faz. Eu vivo uma vida que é muito natural para mim, eu não preciso mais estar num lugar fechado com puros homossexuais, não mais. Eu fico rodeada de pessoas hetero e vivo uma vida normal. Desde que eu cheguei não tenho ido a uma balada gay, acredita $\square$ Não fiquei interessada em ir, na Venezuela a mesma coisa. No único lugar onde frequentava baladas gays foi no Peru. Por exemplo, quando eu morei aqui na Rio Branco, tinha uma praça pertinho da onde eu morava, lhe chamavam "praça dos gays", eu já passei por aí varias vezes, tem muitos bares, baladas, muitas pessoas... mas eu não fiquei interessada em entrar, não é mais meu rolê.

Eu tenho alguns planos para o futuro. Eu quero fazer um capital, seja para voltar no Peru ou para mandar fazer um negocio lá e daí ir embora para lá. Também quero ter uma companheira... mais nada. Quero alguém que esteja do meu lado. Infelizmente, até agora tenho perdido o tempo com pessoas que não valiam a pena. É muito difícil arrumar alguém que esteja centrada no que quer, difícil achar alguém que tenha claro o que quer fazer. A maioria quer só se divertir num final de semana, beber, dançar e curtir.

$$
* * *
$$

\subsubsection{Cesar}


Eu passei minha infância toda em Chiclayo, as lembranças que eu tenho da infância são os jogos de futebol de rua com meus amigos, todos os dias até as 11 da noite. Também ia para escola e estudava muito. Tenho muitas belas lembranças dos meus amigos da infância, infelizmente a maioria deles estão na cadeia. Da nossa turma somos poucos que levamos uma vida boa, o resto não. Depois na adolescência eu fiz outros amigos, são meus amigos atuais com quem tenho mais contato. Na minha família éramos 4 irmãos e morávamos todos juntos só com minha mãe. Ela trabalhava no mercado no centro da cidade e minha irmã se encarregava de cozinhar em casa. Minha mãe vendia fruta no mercado. Desde criança eu acordava ás 5 da manha todo o dia para ajudar minha mãe a montar a barraca no mercado. Eu fazia as compras no mercado atacadista e lavava tudo no mercado para minha mãe vender. Dai minha mãe chegava ao posto de frutas as 8 horas com o café da manha pronto. Eu voltava para casa e ajudava minha irmã a preparar o almoço. Depois ao meio dia eu levava a comida para minha mãe e dai eu ia para escola.

Eu estudei toda a primaria em Chiclayo, mas devido à violência dos anos 80 nos mudamos ao campo com toda minha família. Foram os períodos dos anos 80 e 90, quando estava o movimento de Abimael Guzman (Sendero Luminoso). Eu lembro que quando estávamos em Chiclayo escutávamos os carros bomba, as vezes escutávamos explosões no mercado modelo. Vivíamos com muito medo por isso minha mãe decidiu ir embora e mudar-nos ao campo. Nos mudamos para lá pela situação econômica também. Minha mãe era de um povoado chamado Buenos Aires em Alto Piura, ao norte do país. Eu morei lá vários anos e fiz novas amizades nesse povoado. Foram uns anos muito lindos porque a gente estava perto da natureza. Na temporada de férias saiamos sempre a brincar nas chacras. Minha mãe criava veados ao igual que todos os vizinhos.

Parávamos muito fora de casa, nas casas de outros amigos ou nas chacras, só voltávamos para comer e quando chovia. Eu ajudava minha mãe a cuidar os animais, ela também tinha uma pequena loja de conveniência em casa. Eu gostei muito dessa época, muito. Naquela época quando eu cheguei nesse povoado não tinha luz elétrica, só luminárias de querosene e também a gente cozinhava com lenha. Depois de alguns anos, e quando a violência se acalmou um pouco a gente voltou para a cidade. Eu já tinha como 14 anos quando voltamos para Chiclayo.

Já na adolescência eu entrei num time de futebol da minha cidade, o Aurich de Chiclayo. Mas eu tive que deixar de jogar porque minha mãe me diz que ninguém 
podia me apoiar, então me dediquei só aos estudos. Terminei a escola e continuei ajudando a minha mae na sua banca de frutas até que eu fui a Lima para trabalhar.

\section{"em Lima o dinheiro não me alcançava para viver"}

Minha irmã já morava lá e eu fui para acompanhá-la, fui só por uns dias, meus amigos também estavam estudando lá. Em Lima consegui ficar só dois meses porque não me alcançava o que ganhava para viver. Trabalhei numa oficina de costura em Gamarra, eu era basicamente ajudante, alcançava fios e outros materiais de costura aos costureiros, embolsava as blusas e roupa que saia. Lá me pagavam 60 soles semanalmente, mas não me alcançava para viver! Era muito pouco! Daí voltei a Chiclayo e comecei meus estudos em cozinha. Foi justo a época da Copa América e um hotel conhecido pediu praticantes das escolas de cozinha, estava selecionando estudantes e eu fui uns dos selecionados para trabalhar como praticante. O contrato era só por um mês, mas fiquei trabalhando naquele hotel dois anos, adquiri muita experiência.

Depois de vários anos decidi ir embora para Lima, onde já morei por muito tempo. Primeiro morei na Victoria, depois me passei a Puente Piedra, El Agustino e antes de vir estive morando em Comas. Em Lima continuei meus estudos, mas foi muito difícil porque estudava e ao mesmo tempo tinha que trabalhar para viver. Trabalhei o tempo tudo em cozinha. Foi assim que terminei meus estudos e comecei a trabalhar num restaurante de mariscos onde conheci à mãe da minha filha. Estivemos juntos um bom tempo até que nasceu minha filha e dai abrimos juntos um local de comida em um bairro da periferia. Basicamente vendíamos lomo saltado, tallarin e Chaufa. Mas por motivo de discussões, brigas e emadureces nos separamos e o negocio também acabou.

Já separado, entrei a trabalhar em vários outros restaurantes até que um conhecido que estava morando aqui em São Paulo me contatou e me propus vir a trabalhar com ele como cozinheiro num restaurante. Assim foi que decidi vir, também porque as coisas com a mãe da minha filha não estavam bem. A gente já estava separado, mas a situação se complicou muito porque ela não me deixava ver a minha filha. Bom, eu sou consciente que lhes passava pouco dinheiro, mas era porque não me alcançava, tinha que pagar meu quarto, as passagens e não alcançava para passar-lhes o suficiente. 
Então eu pensei - "primeiro que nem posso ver minha filha, segundo, aqui ganho muito pouco e não me alcança para enviar-lhes dinheiro, se eu venho para o Brasil já alcançará para enviar-lhes mais”. Então eu decidi vir. Minha família tampouco sabia que eu vinha. Eu só avisei a minha mãe quando estava aqui em São Paulo. Eu menti para ela, falei que ia para um acampamento em Cusco a trabalhar na cozinha de uma Mineradora. Porque se eu falava para ela que ia embora do Peru, ela não tivesse deixado isso acontecer e minha passagem já estava comprada. Tampouco pude despedir-me da minha filha porque nem sequer podia vê-la. Foi assim como eu cheguei.

Eu cheguei de ônibus, foi uma viagem muito longa, duro como cinco dias, mas mesmo assim não a senti tão pesada. Fiz amizade no ônibus, a gente brincava, contávamos piadas. O dia e a noite toda eram só gargalhadas, assim você não sente tanto a viagem. Eu vim na empresa Ormeño, é a única, tivesse preferido vir de Kombi. O ônibus quebrou muitas vezes e a gente teve que sair do ônibus em varias ocasiões para ajudar a empurrar.

“meus amigos são todos latinos"

Finalmente, cheguei em São Paulo, lembro que cheguei direto na estação Tiete e era um dia de chuva. Fomos direto a dormir na ocupação onde ele morava. Já no dia seguinte fomos trabalhar, me levou a vender comida com ele na rua aí perto da Rio Branco. E depois de um tempo fui vender comida na feirinha de madrugada de Brás, onde estou até agora. Pessoalmente, tenho feito muitas amizades na feirinha. Tenho amigos bolivianos, clientes bolivianos, amigos colombianos, peruanos, alguns chilenos. Brasileiros conheço muito pouco porque eu não falo bem a língua deles. Todo o tempo que eu estive aqui não falei com brasileiros.

Eu acho que é porque meus clientes são mais latinos, então eu falo mais com eles do que com os brasileiros. Eu fico com raiva quando os latinos me falam em português. as vezes quando encontro bolivianos e me falam em português, eu falo para eles "cara, eu sou peruano, falo espanhol, por que me falas em português?"

Eu acho que aqui os bolivianos são os mais sofridos. Tem muitos peruanos que andam aprontando com eles, esses são os peruanos mais "criollos", mais expertos. Os 
bolivianos são mais ingênuos. Tem muitas pessoas, brasileiros ou não que abusam dos bolivianos, eu tenho visto muito disso. Mas é porque eles buscam ser tratados assim. Tem bolivianos, por exemplo, que mijam na rua e o pior é que na frente de algum vizinho brasileiro, que educação você pode demostrar fazendo isso? É justificável que depois as outras pessoas comecem a falar e tratar mal os bolivianos por fazer isso. No meu caso eu me comporto bem, não faço bagunça, não faço barulho, tento ficar entre minha casa e meu trabalho. Porque se você vai ficar fazendo barulho, quebrando garrafas de vidro na rua, isso vai dar problemas.

"No Peru a situação esta bem para uns poucos"

O problema é que no Peru se trabalha muito e se ganha pouco. não existem nem benefícios nem direitos laborais. os estudantes sempre são explorados, são poucos os praticantes que conseguem uma ajuda ou trabalhar de uma maneira justa. O que acontece é que no Peru tem muita competência, a oferta de cozinheiros é altíssima, então os donos dos restaurantes pagam o que eles querem e as vezes nem pagam. São poucos os restaurantes que pagam o justo. Eu penso que o Peru é um pais lindo, mas não gosto como as coisas estão por lá. sinceramente eu prefiro São Paulo do que Peru. São Paulo é menos barulhento que Lima. Gosto mais da cultura daqui, aqui o transito é mais organizado, as pessoas jogam o lixo na lixeira, no Peru não é assim. Em Lima as pessoas não respeitam o que não é delas, não respeitam a zona que não lhes corresponde, o transito é um inferno, a cultura é um pouco baixa. Eu chamo de cultura baixa ao fato de você ter um papel na mão e jogar na rua. Isso a mim me incomoda muito, conheço pessoas inclusive que são professionais que não tem educação e jogam tudo seu lixo na rua. Por outro lado, a economia... dizem alguns que esta melhorando, eu não sei, eu acho que esta melhorando, mas só para alguns quantos. De Lima me incomoda muito a delinquência, a inseguridade que se vive lá, a mesma coisa acontece com minha cidade. Chiclayo era uma cidade que antes eu gostava muito, agora não gosto mais, tem muita delinquência.

Eu voltaria para o Peru sim, mas para ver minha filha, minha família. Desde que eu cheguei fui só uma vez no Peru, mas voltei muito rápido, não quis ficar. Primeiro porque não me deixaram ver minha filha, então só visitei minha mãe, família e irmãs. Se me deixassem ver minha família eu ficaria mais tempo, um mês os dois meses, mas como não posso vê-la não faz sentido ficar muito tempo lá. voltar no peru para ficar e 
morar de novo, acho que não. Eu já me acostumei à vida daqui. Não gosto mais de lá, não gosto da cultura de lá. Gosto sim, do meu povo, dos meus amigos, minha família.

Gosto da comida gostosa de lá, da comida fresca e saborosa de lá. aqui a qualidade é muito ruim, a qualidade dos frangos, dos temperos. Lá tem mais insumos, aqui não. A gente faz um esforço para fazer comida peruana com os temperos e insumos daqui e assim se assemelhem um pouco à comida de lá. Em quanto a cultura gastronômica, Peru tem muito mais futuro. O problema é que lá também tem muita competência, então você tem um restaurante, na frente outro e do lado outro. Aqui não é tanto assim, tem muito trabalho para cozinheiros peruanos, até me dou o luxo de rejeitar empregos. Por exemplo, aqui me chamam de um restaurante peruano para ir ajudar eles um dia, e eu não vou o vou no dia seguinte.

Eu quero ter um negocio de comidas e assim ficar no Brasil, mas conheço muitos amigos que tem fracassado nisso. Quero colocar um restaurante, quero ter um local próprio, pequeno e simples, mas com um bom atendimento. Estou tentando me associar com outros amigos e ver em que zonas é mais conveniente colocar um. Tenho um projeto com o dono de um café latino na Bela Vista, a gente esta pensando abrir um restaurante, eu já ofereci para ele as possibilidades, se ele aceitar tudo bem, senão eu sigo meu caminho e me concentro no meu projeto. Outro dos meus projetos é comprar uma Kombi e vender ceviche assim, na rua... isso é o que eu quero fazer... por em quanto... como eu te falei, estou indeciso. 
CAPITULO 3

3. O TRABALHO DOS IMIGRANTES PERUANOS NA FEIRINHA DA MADRUGADA 


\subsection{Espaço e território em contexto de imigração}

Os avanços das tecnologias da informação, comunicação e transporte caracterizam o mundo contemporâneo, tornando as grandes cidades em centros de processos sociais, culturais, políticos e econômicos que traspassam os limites do próprio estado-nação. A internacionalização e mobilidade do capital produziram uma reconfiguração das atividades econômicas repercutindo diretamente no mercado de trabalho a nível mundial. Essa reconfiguração, somada aos conflitos internos de cada pais expressados em crise econômica, politica e social impulsionam a imigração de milhões de pessoas que buscam um futuro além das fronteiras dos seus países. As grandes metrópoles intervêm diretamente nos vínculos culturais, sociais e familiares dos imigrantes, mas também podem se tornar um lugar onde os sujeitos (re)elaboram no urbano novas formas de pertencimentos e identidades (LEFEBVRE, 2004).

A imigração contemporânea não pode ser mais explicada pelo tempo de permanência dos indivíduos nem pela direção dos seus deslocamentos "Conceitos como mobilidade da força de trabalho e exercito industrial de reserva também não satisfazem mais as formas de explicar o mundo no qual o migrante é integrado" (HEIDEMANN, 1998, p. 16). A imigração, por sua vez, é um fenómeno social, histórico, psicossocial e também geográfico por possuir implicações a nível territorial e existencial. O migrante é deslocado do seu lugar de origem e é justamente nessa mobilidade que se pretende encontrar o significado de ser imigrante analisando os processos de desterritorialização e reterritorialização.

Para falar de novas territorialidades e multiterritorialidades é preciso abordar algumas definições em relação a território e territorialidade. Primeiramente é importante estabelecer uma distinção entre espaço e território, termos que em ocasiões são erroneamente relacionados como equivalentes. $\mathrm{O}$ espaço antecede ao território, não tem valor de troca, mas de utilidade. O espaço é como se fosse dado, uma espécie de matéria-prima que antecede a toda ação (RAFFESTIN,1993). O território é o espaço no qual os seres se organizam, articulando e delimitando-se com outros espaços já existentes. "O espaço é a prisão original, o território é a prisão que os homens constroem para si”. (op. cit. p, 144). A territorialidade, além de conter uma dimensão politica, engloba também relações culturais e econômicas já que esta estreitamente ligada à forma como as pessoas se organizam no espaço, à utilidade que as pessoas dão para a terra e ao conjunto de significações que dão para o território. 
O território é uma produção a partir do espaço, é uma construção social que resulta da ação das relações de poder. O poder a sua vez, é a parte intrínseca de toda relação e tem implicâncias em todas as praticas espaciotemporais. A relação territóriopoder é então inquestionável, mas não se refere unicamente ao poder tradicional e absoluto, aquele mais visível e identificável como o Estado-poder. Refere-se ao poder concreto e simbólico da produção do espaço partindo das percepções, vivencias e concepções no nível individual, grupal e social. O poder concreto ou de dominação esta vinculado ao valor de troca e à funcionalidade do espaço. Este poder guarda estreita relação com a dominação politica e econômica, própria das sociedades modernas capitalistas. O segundo tipo de poder é o simbólico ou de apropriação, guarda relação com o valor de uso e compreende os aspectos culturais, simbólicos e marcas do vivido do espaço.

A apropriação e a dominação do território deveriam ir juntas e, no melhor dos casos, a apropriação deveria prevalecer sobre a dominação. Mas infelizmente a dinâmica de acumulação no sistema capitalista faz que a dominação se anteponha à apropriação, impedindo que os territórios sejam re-apropiados por estar dominados pelo estado e pela empresa privada. (LEFEBVRE, 1986; em HAESBAERT, 2004).

A sua vez o território, compreendido como espaçotempo vivido, é sempre múltiplo. É diverso, complexo e não unifuncional como a lógica capitalista o define, reduzindo o território no sentido do valor de troca transformando-o em mercadoria. Sob essa condição de diversidade e complexidade, própria dos processos de apropriação e dominação, é que se deve pensar na multiplicidade de manifestações do território e, ao mesmo tempo, diversidade de poderes a traves dos diferentes sujeitos involucrados. Os territórios deveriam estar diferenciados de acordo com os diversos sujeitos ou agentes que os compõem, sejam indivíduos, grupos, empresas, estados, instituições, etc.

O território apresenta seu próprio processo histórico, atravessando por uma serie de variações e transformações no decorrer do espaçotempo. Em outras palavras, os processos de territorialização ao longo das diferentes sociedades históricas vão adquirindo diferente significado. Assim, Haesbaert (2004), diferença três tipos de sociedades ao longo do tempo: sociedades tradicionais, sociedades disciplinares modernas e sociedades de controle ou pós-modernas. Nas sociedades tradicionais, a apropriação simbólica do território, dotava de sentido o espaço na sua totalidade mantendo assim sua cultura manifestada também a traves de uma profunda identificação com seu território. Nessas sociedades o território era mais estável e ao mesmo tempo 
excludente em relação a outros grupos socioculturais. Nas sociedades modernas o território adquire um sentido utilitarista ao ser considerado um instrumento de domínio para o conhecimento das necessidades humanas. Nessas sociedades a construção da identidade individual é mais importante do que a grupal, reforçando assim o individualismo dos sujeitos, levando em conta que é um objetivo dessas sociedades disciplinar a traves do espaço.

A sociedade moderna capitalista, chamada por alguns como mundo pósmoderno, caracteriza-se porque o objetivo da territorialização é construir e, sobretudo, controlar os fluxos e a mobilidade dos sujeitos, da informação e das mercadorias. O território transforma-se então num território-rede, sendo a mobilidade um elemento crucial para a sua construção. A fragmentação do território, produto da nova organização condicionada pelos fluxos, redes e mobilidades, faz possível a assimilação de culturas estrangeiras no mesmo território.

Para começar a ampliar a nossa concepção de territorialidade é importante desconstruir o pensamento dicotômico entre mobilidade - fixidez, rede - territórios. Nosso tempo e contexto atual exige a aceitação de uma diversidade territorial, onde novos circuitos de poder desenham territorialidades cada vez mais complexas e diversas; em contraste com a ideia uniterritorial cuja única forma de controle, seguindo a logica capitalista, é a estatal, controlando os fluxos, áreas e fronteiras com fines políticos e econômicos.

Haesbaert identifica múltiplos territórios a traves de quatro tipos de territorialização. O primeiro são as territorializações mais fechadas, como é o caso de alguns grupos étnicos, cujo único território impõe uma homogeneização cultural tolhendo a existência de varias identidades assim como varias formas de poder. Outra territorialização é a mais tradicional como é o caso dos territórios centrados no estadonação, os quais admitem certa diversidade mais não aceitam pluralidade de poderes. A terceira é a territorialização mais flexível que admite a sobreposição territorial, onde espaços multifuncionais coexistem nas áreas centrais das grandes cidades. E por ultimo encontram-se as territorializações múltiplas, características do contexto atual, de evidente mobilidade com presença de infinitas redes e fluxos. São as denominadas multiterritorialidades, conformadas por grupos e indivíduos que constroem seus territórios com conexão flexível de múltiplas funcionalidades e múltiplas identidades.

Segundo o autor, os humanos vivenciamos em todas nossas relações sociais (que são ao mesmo tempo relações de poder) diversos entrecruzamentos territoriais, pudendo 
experimentar aso mesmo tempo vários territórios constituindo assim nossa multiterritorialidade. Nas ciências sociais fala-se também de um multipertencimento territorial afirmando que:

A relação entre o individuo ou grupo humano e o território não é uma relação biunívoca. Isto significa que nada impede este individuo ou este grupo de produzir e de habitar mais de um território. (...) é raro que apenas um território seja suficiente para assumir corretamente todas as dimensões de uma vida individual ou de um grupo. $\mathrm{O}$ individuo, por exemplo, vive ao mesmo tempo ao seu nível, ao nível de sua família, de um grupo, de uma nação (BAREL, 1986:135; em HAESBAERT, 2004).

O autor afirma que só um território não é suficiente para todas as dimensões de uma vida individual ou grupal. Os sujeitos vivemos no mesmo tempo num nível individual, familiar, grupal, nacional, etc., acomodando e articulando hierarquicamente nossos territórios nas diferentes dimensões do vivido. As multiterritorialidades compreendem então mudanças não só de maneira quantitativa, ao dispor de mais territórios, senão também qualitativa, ao poder combinar as vivencias e iterações em diversos territórios.

É justamente a traves da multiterritorialidades que poderíamos compreender as identidades e territorializações contemporâneas, já que nossos territórios atualmente estão sendo construídos mais por movimento e descontinuidade do que por fixação e rigidez. Um amplo exemplo é a dinâmica migratória. No caso dos migrantes, a formação de bairros, mais do que ser uma demanda da necessidade por moradia accessível com os seus salários, representa uma possibilidade de construir novas territorialidades onde, a traves de restaurantes, lugares de comercio de produtos dos seus países de origem, discotecas, canchas de futebol e demais lugares de encontro, os migrantes sentem-se parte do espaço da cidade. Os migrantes, na medida em que cheguem a pertencer a dois mundos simultaneamente, tentam manter, alguns de maneira existencialmente conflituosa, a memoria e costumes que os ligam a seu território de origem e, ao mesmo tempo, tem a necessidades de estabelecer novos contatos e diálogos com o novo lugar que constitui seu cotidiano, (re)construindo suas identidades, identificações e significados. Esses processos:

Descrevem aquelas formações de identidades que atravessam e intersectam as fronteiras naturais compostas por pessoas que foram dispersadas (migrantes) para sempre de sua terra natal. (...) Elas retém fortes vínculos com seu lugar de origem e tradições, mas sem a ilusão 
de retorno ao passado. Elas são obrigadas a negociar com as novas culturas em que vivem, sem simplesmente serem assimiladas por elas e sem perder completamente a sua identidade. (...) devem aprender a habitar no mínimo duas identidades, a falar duas linguagens culturais, a traduzir e negociar entre elas (HALL, 1996:95; EM HAESBAERT, 1999).

Em outras palavras, o migrante quebra a concepção tradicional de território, cuja logica de território nacional afirma erroneamente a existência de limites e fronteiras territoriais bem delimitadas com identidades estáveis. As identidades mudam de acordo com o contexto espaço-temporal e com a maneira como as pessoas são reconhecidas, não existindo assim um foco único de identidade. Os sujeitos, dependendo das suas necessidades e interesses podem tornar suas identidades plurais, sendo estas ganhas ou perdidas. As redes aqui jogam um papel importante por revelar o caráter, flexível, dinâmico e relacional da ideia de identidade. O imigrante, como sujeito que se sente fazendo parte de dois ou mais territórios ao mesmo tempo, apresenta uma identidade cambiante, múltipla e diversa. E é justamente que partindo da noção das diversidades poderíamos repensar a dinâmica social mundial em todas suas dimensiones, construindo assim uma sociedade mais igualitária e inclusiva reconhecedora das diferenças humanas.

\subsection{Os imigrantes no mercado de trabalho brasileiro}

Para Silva (2005), a maior parte dos imigrantes hispano-americanos ${ }^{5}$, vem para o Brasil a trabalhar em setores do mercado laboral que não exigem uma qualificação previa e onde não recebem a nenhum tipo de direitos trabalhistas. Muitos dos imigrantes aceitam as condições de trabalho já desde seus países de origem, onde a traves de redes familiares e redes de captação de mão de obra - como donos de boxes de venda nos mercados populares, donos de restaurantes nos casos dos peruanos, donos de oficinas de costura, no caso dos bolivianos - chegam no Brasil para trabalhar em setores específicos como costura, comércio, cozinha e serviços domésticos.

Nos casos onde os imigrantes chegam em São Paulo por conta própria e sem contato com redes que facilitam a sua colocação nos setores acima mencionados, as

\footnotetext{
${ }^{5}$ A partir do estudo sobre imigrantes peruanos, bolivianos e paraguaios e o mercado de trabalho em São Paulo, desenvolvido pelo autor.
} 
opções para inserir-se no mercado de trabalho são sempre restritos, situação que se agrava ainda mais quando o imigrante carece de documentação. $O$ aumento da circulação de mercadorias, dinheiro e pessoas, somada à demanda por mão de obra mal remunerada, encontra quase sempre nos imigrantes indocumentados, os sujeitos indicados para desempenhar todo tipo de trabalhos à margem dos direitos, submetendose por necessidade a condições deploráveis.

Como vimos anteriormente, o capitalismo, na sua fase atual de reestruturação produtiva, vem sometendo à sociedade contemporânea às transformações mais destrutivas, sobrepondo a produção de mercadorias aos direitos do homem. As modalidades de trabalho surgidas a partir dessa lógica vem aprofundando as mais diversas formas de precarização e informalidade, fazendo uso de velhos mecanismos de intensificação como a autoexploração do trabalho, tal é o caso dos imigrantes:

Seria necessário recordar que, em pleno século XXI, há jornadas de trabalho, em São Paulo, que chegam a dezessete horas por dia, na indústria de confecção, onde trabalham imigrantes bolivianos ou peruanos controlados por patrões coreanos ou chineses, aflorando um traço pouco visível e brutal da chamada "globalização", que configura modalidades de trabalho imigrante no limite da condição degradante (ANTUNES, 2015, p.245).

O caso dos imigrantes bolivianos, cujo trabalho nas oficinas de costura foi associado com o trabalho análogo ao escravo, representa o lado desumano de uma economia globalizada. A maioria deles são imigrantes subcontratados por empresas terceirizadas de grandes multinacionais e redes de lojas brasileiras, tendo como exemplo a empresa de roupas e acessórios C\&A, quem tinha aproximadamente sessenta oficinas de costura mantidas a partir do trabalho escravo de imigrantes bolivianos. Nas oficinas de costura, geralmente o pago recebido é por peça, levando assim a uma autoexploração, já que devem responder às exigências do patrão, os quais muitas vezes os deixam sem salário por vários meses. Quando não é alcançada a meta, ou ocorre algum problema na produção, os trabalhadores podem ser ainda agredidos fisicamente, como informam alguns imigrantes.

Outras formas de violência são cometidas contra esses trabalhadores como a proibição de sair do lugar onde trabalham e moram sob tudo tipo de ameaças, ademais de receber uma pesa alimentação causando-lhes diversas doenças, incluídas as já adquiridas a raiz das condições físicas de um lugar sem ventilação, e com grande quantidade de poeira e fuligem, o que desencadeia em conjuntivites, problemas 
pulmonares e tuberculoses (SILVA, 2005, p.27). No caso dos bolivianos e peruanos, a atividade de costura é para eles uma atividade transitória já que a maioria deles desempenhava nos seus países um outro tipo de trabalho. Em vários casos depois de algum tempo trabalhando nas oficinas, alguns imigrantes optam por trabalhar por sua conta costurando de maneira independente ou se dedicando a comercializar produtos nas regiões de comercio popular na cidade.

A situação dos imigrantes peruanos inseridos no comercio de artesanato não é muito diferente em relação ao ramo da costura. A maior parte desses imigrantes são trazidos por outros familiares ou alguma rede de compatriotas donos de lojas, os quais lhes prometem salários altos e possibilidades de ganhar muito dinheiro em São Paulo. A mercadoria geralmente já é feita em São Paulo, e do mesmo modo que na costura, o pagamento é por peça, recebendo em torno de dez a vinte reais por milheiro de objetos diversos como pulseiras, brincos, enfeites para geladeira, entre outros. Esses trabalhadores, embora o desgaste físico e mental que origina a dinâmica de este tipo de serviço percebe sua situação de maneira positiva e transitória, já que a aspiração é sair da sua condição de exploração e virar donos das oficinas, de alguma loja, o de algum pequeno negócio (op, cit, p.28).

Por outro lado, a raiz do boom gastronômico da comida peruana no mundo, começou a propagar-se em muitos países numerosos restaurantes de culinária peruana, principalmente nas cidades que albergam grande quantidade de imigrantes peruanos como Santiago de Chile, Buenos Aires, Caracas, São Paulo e algumas cidades dos Estados Unidos. E, com a propagação de restaurantes, cresce também a demanda de funcionários, principalmente chefs e ajudantes de cozinha. A partir do depoimento de um dos entrevistados se observou a modalidade que os donos dos restaurantes empregam na captação de cozinheiros para trabalhar nos restaurantes ou negócios de comida na cidade de São Paulo. Esta modalidade consiste em contatar jovens estudantes e praticantes de cozinha das escolas e institutos de gastronomia em Lima e do resto de províncias, ou então, chegar às estações de trem Tiete ou Barra Funda onde geralmente chegam os imigrantes peruanos em São Paulo. Em qualquer dos casos, o "pacote completo" é oferecido com antecipação pelos donos, o qual consiste em casa, comida e salario, sendo o salário insuficiente e com exaustivas horas de trabalho - acima de 10 horas por dia - ademais da carga e pressão psicológica por parte dos donos dos restaurantes. 
Segundo referencias de um entrevistado, a maioria dos jovens não aguenta muito tempo nessas condições de trabalho e, passado um período de tempo, mudam para outro restaurante que ofereça melhores condições e melhores salários. Em outros casos os jovens acabam trabalhando por conta própria, seja vendendo comida na rua em pequenos carrinhos, principalmente em zonas com muita presença de peruanos, ou vendendo marmitas de comida peruana por delivery, usando geralmente as redes sociais como Facebook, nos grupos de imigrantes ou residentes peruanos em São Paulo. Situação parecida acontece com os jovens trazidos para trabalhar como ajudante de vendas na rua, seja no comercio de um familiar o algum conhecido, passado um tempo e com um pouco de dinheiro poupado, eles conseguem comprar sua própria mercadoria e sair nas ruas para revender, acoplando-se nos mercados populares da cidade como nos casos da feirinha de madrugada.

\subsection{Peruanos comerciantes na feirinha de madrugada do Brás- SP}

Como consequência da profunda recessão econômica a nível mundial desencadeada pela onda inflacionaria do inicio da década de 70, as décadas dos anos 1970 e 1980 representam uma fase de transformações estruturais, expressadas em importantes reestruturações politicas, sociais e econômicas. Este período de transição esteve marcado por grandes instabilidades e incertezas manifestadas na organização do trabalho e na vida social das pessoas. Dá-se inicio assim, a um modelo de sociedade proposto pelo logica neoliberal, isto é, um modelo de acumulação flexível e com ele, o trabalhador flexível. Essa mudança forçou assim uma modificação na base produtiva, afetando diretamente o mercado urbano de trabalho, onde a precarização e flexibilidade apareceram como as características mais visíveis nessa nova organização do núcleo laboral.

Nos países com capitalismo avançado observou-se uma redução da classe operaria manual, seja pelas recessões na economia dos países, seja pelo desenvolvimento tecnológico que levou a uma automatização e robotização da indústria. A outra tendência propagada por esses países da Europa Ocidental, estados unidos e Japão ao resto do mundo, foi a cada vez mais acelerada precarização do trabalho, a subcontratação e sobretudo, aumento de empregos de tempo parcial ou os tão conhecidos Freelance. Todas essas mudanças aprofundaram uma regressão em direitos 
laborais e sociais a nível mundial, reduzindo assim todas expressão e participação de organização sindical.

Nas palavras de Antunes (2015), na fase atual do capitalismo, o mundo do trabalho vem sofrendo profundas modificações, sendo uma das características mais marcantes os crescentes processos de desproletarização e subproletarização do trabalho, isto é, uma diminuição significativa da classe operaria tradicional e um incremento do trabalho de tipo parcial, temporário, subcontratado e terceirizado. Este processo contraditório de diminuição de operários e aumento de sub-operários a traves do trabalho precário origina um acelerado e preocupante desemprego estrutural.

$\mathrm{O}$ medo ao desemprego, presente inclusive nos trabalhadores mais privilegiados da estrutura econômica salarial, leva a tolerar posturas autoritárias que transgredem os direitos laborais conquistados arduamente, a aceitar as alterações nas jornadas de trabalho e redução de salários. Toda essa condição de precariedade é sustentada pelas próprias empresas, as quais para reduzir os custos, fugir das suas obrigações legais como entidades empregadoras e evitar a intervenção dos sindicatos, decidem contratar serviços e produção de outras entidades econômicas menores, que a sua vez sobrevivem graças aos baixos salários dos seus empregados. Por outro lado, a crescente dificuldade para a inserção laboral num mercado de trabalho com escassas oportunidades, estimula a concorrência entre os diferentes segmentos de trabalhadores incitando à individualização e desestimulando a ação coletiva dos empregados na procura do cumprimento dos seus direitos.

Nos países latino-americanos a precarização aparece então como uma manifestação da nova dinâmica das relações de trabalho presente na contratação, na jornada de trabalho e na remuneração prejudicando diretamente as condições laborais, como se observa em alguns países da região:

Grandes empresas do setor têxtil brasileiro transferem plantas do Sudeste para o Nordeste, organizando-as por sobre uma rede ampla de produtores à domicilio, com níveis de remuneração muito mais baixos que aquele anteriormente obtido pelos trabalhadores assalariados têxteis. Empresas internacionais se implantam nas Zonas de Produção para Exportação no norte do México, aproveitando-se das vantagens de utilizar mão de obra abundante em regime especial de trabalho (CASTRO \& DEDDECA, 1998, p. 15).

Nota-se que no interior dos países latino-americanos as politicas econômicas favorecem exclusivamente ao mercado externo e as multinacionais, onde o investimento 
aparece por cima dos direitos cidadãos, o mercado sob o estado, a economia sob a politica e o crescimento do PIB sob a luta pela igualdade e inclusão. A sua vez, em países com uma historia marcada pela desigualdade, essas drásticas medidas adotadas aprofundam a marginalização no mercado de trabalho revelando a profunda desigualdade de oportunidades, preconceito e exclusão, onde jovens, mulheres, imigrantes, negros e indígenas, na procura de um médio de subsistência nesse agressivo médio capitalista, sometem-se às formas mais cruéis e arcaicas de trabalho como são o trabalho infantil, o trabalho escravo e formas de trabalho degradante.

Por outro lado, os estudiosos das dinâmicas urbanas buscaram na segunda metade do século XX, ter uma maior compreensão sobre a crescente desigualdade econômica própria da acelerada urbanização a partir da década dos anos 1970 nos países subdesenvolvidos como o caso da América Latina. Começou-se assim a analisar a dinâmica urbana a traves de dois subsistemas da economia, teoria que levou o nome de "Teoria dos dois Circuitos". A modernização tecnológica das cidades produziu transformações na economia cujos efeitos são percebidos nas dinâmicas de produção, circulação e distribuição de mercadorias, dinâmicas que se produzem a partir de dois subsistemas ou circuitos que atuam em conjunto: o circuito superior ou o mais moderno e o circuito inferior ou marginal. Cabe ressaltar que a diferença fundamental entre os dois circuitos esta baseada na tecnologia empregada, no modo de organização do trabalho e ne uso de capital. Ambos os circuitos têm a mesma origem, causas e estão interligados, porém o circuito inferior aparece como dependente do circuito superior (SANTOS, 2004).

O circuito superior é o resultado direto da modernização, esta composto pelos bancos, os grandes monopólios e pelas grandes empresas, cujo poder no mercado financeiro é alto e cujas atividades estão voltadas a servir ao progresso tecnológico e à população que se beneficia dele. As atividades dentro deste circuito estão baseadas no uso da publicidade como uma importante arma para modificar os gostos e deformar o perfil da demanda. $\mathrm{O}$ outro circuito, denominado de inferior, é o resultado indireto do processo de modernização e esta composto por atividades de pequena dimensão tecnológica, de pouco capital e que requerem do uso de mão de obra intensiva. Este ultimo circuito beneficia só ás pessoas que não se beneficiam em absoluto ou só parcialmente das vantagens do progresso técnico. Nesse circuito inferior, a diferença com o superior, a publicidade não é necessária devido ao contato direto que se tem com 
a clientela. Alias, a margem de lucro nesse setor vai diretamente à pessoa ou à família que dele se beneficiam.

Um aspecto fundamental que marca a diferença nesses dois circuitos é a presença do estado em ambos os casos. As atividades do circuito superior se beneficiam direta ou indiretamente da assistência dos órgãos governamentais. Por outro lado, o circuito inferior não recebe nenhuma ajuda nem assistência e, pelo contrario, a ação do estado nesse lado é a partir de perseguições, como acontece com os comerciantes ambulantes na maioria de cidades do Brasil e da América Latina. Exemplos das atividades pertencentes a este setor são as realizadas pelos pequenos comerciantes, mascates e vendedores ambulantes, todos voltados para o mercado de consumo local, abastecendo à população com menos recursos e mobilidade. Atividade na qual esta inserida grande parte da população brasileira, os trabalhadores ditos "informais".

O trabalho de rua no Brasil é uma das praticas mais antigas na sociedade brasileira e constitui um dos componentes da cultura e formação das próprias cidades, especialmente cidades litorâneas de grande movimentação econômica como Salvador, Rio de Janeiro e Recife, cuja dinâmicas de cargas e descarga de mercadoria nos seus portos era sempre feita por trabalhadores de rua (DURÃES, 2009). Segundo o autor, já desde o Brasil colônia as cidades eram povoadas por trabalhadores e trabalhadoras de rua e esteve conformado primeiro pelos escravos, seguido dos carregadores já libertos. O perfil do trabalhador de rua na época era de negros, mestiços e alguns poucos brancos pobres os quais se ganhavam a vida dia a dia prestando algum trabalho na rua como carregador de mercadorias assim como oferecendo particularmente seus serviços como de pedreiros, lavandeiras, carpinteiros, etc, em pontos específicos da rua denominados de "cantos", lugares onde essas pessoas esperavam ser chamadas pelos clientes situadas geralmente nas esquinas mais movimentadas da cidade. O interessante é que já desde a época, existia uma fiscalizando por parte da policia, perseguindo e reprimindo violentamente os trabalhadores de rua nos seus pontos.

As praticas de trabalho de rua permaneceriam no Brasil Independente e constituir-se-iam como única forma de sobrevivência das populações de passado escravista. Negros e ex-escravos inseriam-se em trabalhos instáveis, precários e até ariscados, sofrendo perseguições e detenções constantes por parte da policia, detenções carregadas de grande preconceito racial contra esta população. Diante de tal situação, de completa desigualdade e exclusão, Durães desmente a ideia comum de pensar a informalidade como uma escolha racional dos trabalhadores de rua da época: 
as formas de trabalho de rua, desde o século XIX e início do XX, não significaram mera fonte de escolhas individuais dos/as trabalhadores/as. $\mathrm{Na}$ verdade, representavam muito mais a única forma de sobrevivência possível diante de um contexto social excludente e ameaçador como era na época o mundo escravista e das oligarquias rurais do início do século XX (op. cit. p.4).

Não é possível negar a vinculação das praticas de trabalho dentro do circuito inferior com a sociedade capitalista já que esta seria, a sua vez, um produto da crescente divisão territorial como consequências do projeto neoliberal, da concentração de renda e da segmentação da produção e do consumo. Dinâmicas que convivem com o desemprego crônico e o fortalecimento da pobreza urbana.

\subsubsection{A feirinha de madrugada no Brás}

As primeiras atividades de observação e levantamento de dados na pesquisa, começam com as visitas à feirinha de madrugada do Brás, as quais tem seu inicio em junho de 2016. Antes de começar com os relatos e descrição da minha experiência é pertinente contextualizar essas formas de comercio popular dentro do contexto urbano da cidade de São Paulo.

A feirinha de madrugada do Brás, junto as outras feiras e galerias de comercio da rua 25 de Março e Santa Ifigênia fazem parte dos mercados populares que caracterizam a dinâmica urbana do centro de São Paulo. Entende-se por mercado ou comercio popular, os espaços de compras que tem como principais características a aglomeração de pequenas lojas dentro de shoppings, grande concentração de comerciantes ambulantes nas calçadas das ruas com maior atividade e compra e venda de produtos oferecidos a baixo custo (FREIRE, 2014).

Desde os primeiros momentos do processo de urbanização da cidade de São Paulo, a região da rua 25 de março albergou as primeiras feiras populares da cidade na qual se comercializavam produtos vindos da região portuária de Santos. No final do século XIX com a construção do primeiro mercado da cidade, a região se consolidaria como um ponto importante de comercio popular. De acordo com Freire, o centro da cidade atraiu comerciantes vindos de diversos lugares dentro e fora do Brasil:

Imigrantes árabes, sobretudo sírios e libaneses instalaram-se no local, que serviria de base para a atividade dos mascates. No entanto, tais 
migrantes consolidaram-se nesses espaços com as lojas de armarinhos e a distribuição de tecidos produzidos localmente, sobretudo a partir da década de 1930, com o maior desenvolvimento da indústria têxtil nacional (op. cit. p.42).

A partir da década dos anos 1960 levou-se a cabo o processo de degradação do centro da cidade, uma vez que as grandes empresas, na procura de melhores condiciones urbanas e infraestrutura mais moderna para estabelecer suas sedes, deslocaram-se do dentro às regiões da Avenida Paulista e Faria Lima, atuais polos financeiros de São Paulo. Décadas mais tarde, a partir de um estudo realizado pela Secretaria Municipal de Planejamento, mostrou-se que mais do $50 \%$ dos projetos de médio e grande porte - isto é, centros comerciais e shoppings, supermercados e centros empresariais- localizavamse nas regiões do denominado centro expandido, como a Marginal Pinheiros, Vila Olímpia e na Berrini. Essas regiões estariam destinadas basicamente às elites financeiras e moradores mais ricos, resultando em uma revalorização da área devido aos numerosos e modernos projetos urbanísticos, com aportes de investimentos publico e privado (FRÚGOLI, 2000). Desse modo, a expansão da centralidade urbana de São Paulo levou a processos de concentração de renda, poder e gasto publico favorecendo só as classes dominantes, agudizando a segregação e exclusão dos grupos sociais menos favorecidos com os projetos de expulsão das classes populares de zonas determinadas.

Assim, com o distanciamento das grandes empresas e elites da região central, o centro de São Paulo pouco a pouco iria se consolidando como uma área de comercio destinada à população de menor renda. Dentro desse processo de popularização do centro é notória a grande concentração de camelos espalhados em diversas ruas e nas avenidas principais da régio da 25 , santa Ifigênia e Brás.

O Brás, região na qual acontece a feirinha de madrugada, principal foco na presente pesquisa, constitui desde começos do século XX uma importante área de indústria têxtil e centro de produção e distribuição de prendas de vestir. o bairro foi ao mesmo tempo lugar onde se assentavam os migrantes chegados em São Paulo, tanto para trabalhar na indústria quanto para morar. Foi a partir dos anos 1980 com o chamado "processo de reestruturação produtiva" de São Paulo que muitas indústrias dedicadas à área de confeições deixaram a cidade e se deslocaram em direção ao nordeste. "as empresas que ficaram diminuíram o tamanho de suas plantas e passaram a terceirizar a costura, etapa mais intensiva em mão de obra" (FREIRE, 2014:45). Assim, o Brás começa a adquirir uma cara mais de comercio do que de indústria ao albergar 
grande quantidade de postos de venda e lojas que ao mesmo tempo funcionavam como pequenas fabricas e oficinas de costura. Além das lojas e oficinas de costura, começaram a se instalar na região do Largo da Concordia, situada à frente da estação de trem do Brás, centenas de imigrantes nordestinos dedicados á venda ambulante de produtos do Nordeste.

Atualmente, o centro da cidade constitui um importante circuito dentro da economia urbana de São Paulo, sendo também um polo significativo do que o autor denomina "turismo de sacoleiros", ao receber diariamente milhares de revendedores atacadistas chegados tanto de São Paulo capital como de outros estados e regiões do país. o perfil das pessoas que frequentam esses comércios populares é muito variado, sendo que a maior parte são pequenos comerciantes donos de lojas pequenas, ou comerciantes ambulantes que operam em outras regiões. O lugar de procedência desses compradores atacadistas é tanto da periferia e outras regiões da cidade, como dos estados de Minas Gerais, Rio de Janeiro, Santa Catarina entre outros. Existe também a presença de empresas que oferecem serviços tanto de transporte em ônibus, alguns com café de manha incluso, como também de hospedagem em pousadas para facilitar a chegada e permanência das pessoas tanto nas galerias quanto nas feiras da madrugada.

A crescente expansão de galerias e demais formas de comércios populares produz também uma reestruturação urbana do centro da cidade. Ao ser o centro um polo importante de distribuição e circulação de mercadorias, os mercados populares nele assentados tornaram-se "grandes centros atacadistas e espaços altamente valorizados, multiplicando as disputas pela ocupação dos espaços e conflitos com as autoridades publicas" (op. cit. p.16). 
Figura 4: Camelos da Feirinha da Madrugada do Brás no quinto dia de protestos contra a "Operação de combate aos camelos" em outubro de 2011

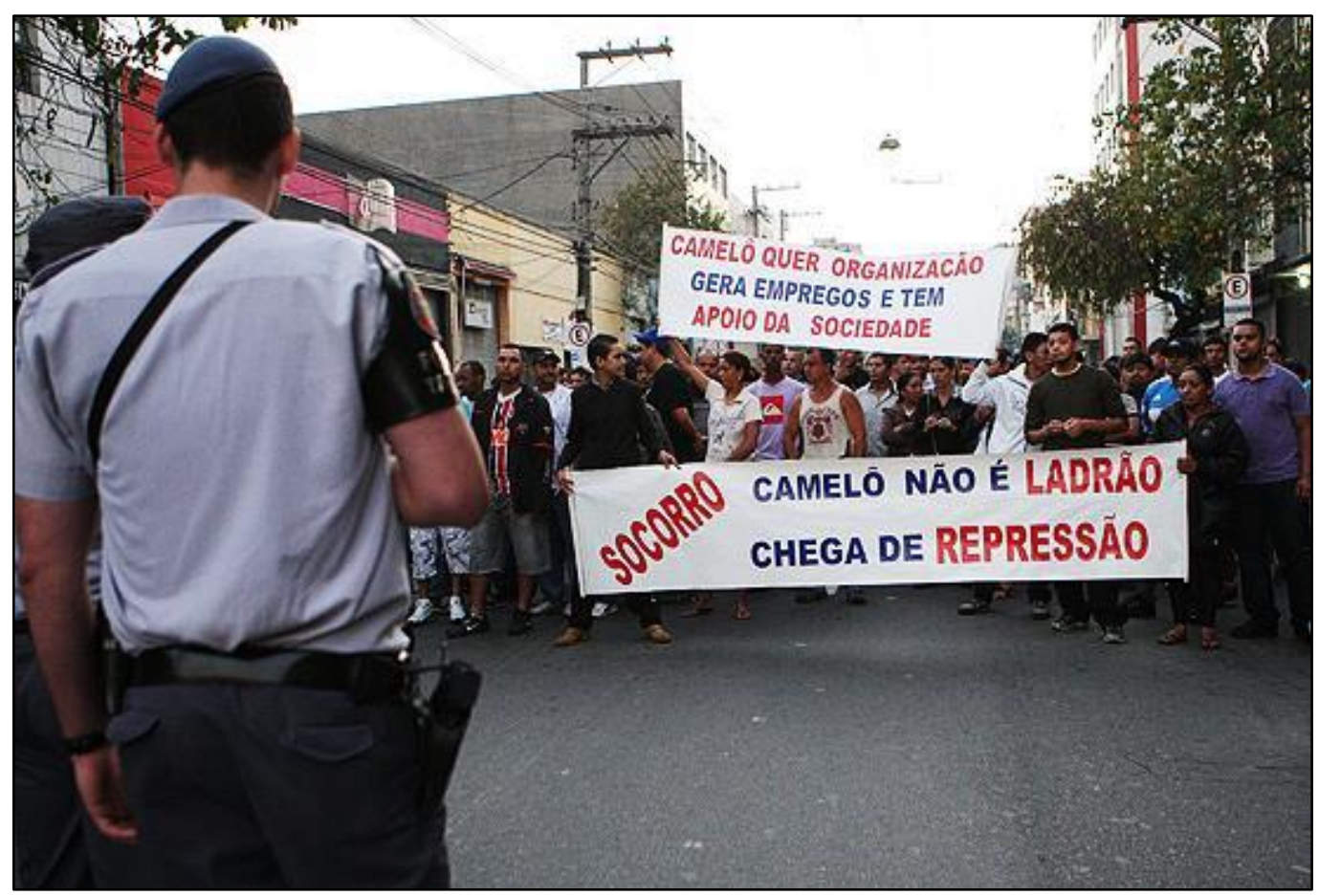

Fonte: http://www1.folha.uol.com.br/cotidiano/998768-protesto-de-ambulantes-interdita-via-na-regiaocentral-de-sp.shtml

É relevante mencionar as constantes ameaças e perseguição policial aos comerciantes ambulantes que pude constatar nas visitas na feirinha e a partir dos depoimentos dos entrevistados. Outras questões importantes surgidas nas narrativas foram o pagamento semanal e obrigatório por parte dos vendedores ambulantes a grupos de policias em retiro a cambio de um serviço de "segurança", e o aluguel e venda de espaços na rua, a qual os camelos denominam de ponto, as quais são pequenas áreas do pavimento demarcadas com giz e estão delimitados e administrados por grupos armados que os imigrantes denominam de matones ou malandros.

Esses mercados populares tem a sua vez uma grande presencia de imigrantes geralmente vindos de países de américa do Sul como peruanos, bolivianos, paraguaios e equatorianos, os quais encontram no comercio ambulante dentro das feirinhas um médio de subsistência na sua chegada ao Brasil. Em casos específicos como o dos bolivianos, o fato de estar trabalhando como camelos nas feirinhas populares, constitui um processo de ruptura da relação de dependência dos costureiros nas oficinas de costura em relação aos seus patrões, bolivianos ou coreanos, proprietários da matéria prima e do produto final que é comercializado em distintas lojas da cidade (SILVA, 2005). Uma vez que 
esses imigrantes já dominam o processo de produção das peças, isto é, compra da matéria prima, confecção e empacotamento, eles conseguem vender por conta própria a mercadoria feita por eles mesmos na feirinha de madrugada do Bras.

A partir de dados levantados de outros estudos sobre imigrantes no mercado de trabalho em São Paulo assim como entrevistas feitas a peruanos e imigrantes de outras nacionalidades é que se obteve informação que eram nas feirinhas de madruga, tanto a que acontece na Rua 25 de Março quanto a da região do Brás, lugares onde a maior parte de comerciantes peruanos se encontravam trabalhando comercializando diversos produtos na rua.

A minha experiência na feirinha de madrugada se deu na noite do 2 de junho de 2016 e foi possível graças ao apoio e disposição de Jandy, a primeira entrevistada nessa pesquisa e grande colaboradora.

Umas semanas antes do encontro escrevi a Jandy uma mensagem contando-lhe sobre minha vontade de conhecer a feirinha de madrugada, lugar do qual já tinha ouvido falar muito por outras pessoas e por ela mesma. Perguntei para Jandy sobre a possibilidade de ir juntas na feirinha e acompanha-la nas suas vendas, já que devido aos horários - um dia de feirinha vai desde as 2 até as 9 da manha - era difícil para mim a questão do transporte publico saindo de Butantã até o Brás nesse horário de madrugada. Jandy se mostrou imediatamente muito emocionada e alegre pelo meu interesse em conhecer a feirinha e acompanha-la e me ofereceu a possibilidade de dormir na sua casa e sair juntas na madrugada seguinte com destino a seu lugar de trabalho. Conforme o combinado, semanas depois sai do Crusp destino estação da Luz, levando o endereço de Jandy em um papel assim como varias indicações de cuidado por parte de meus companheiros de casa.

Era aproximadamente as 10 da noite quando sai da Estação da Luz e andei até a casa de Jandy, na Rua Mauá, do outro lado da passarela. Musica brega, luzes de muitas cores e pessoas festejando lhe davam um tom mais cálido a aquela noite fria e chuvosa do outono paulistano. Andando mais um pouco e atravessando a passarela de pedestres estava Jandy esperando-me. Entramos na sua casa, um imóvel improvisado com paredes de madeira que separavam dois ambientes pequenos um do outro. $\mathrm{O}$ espaço maior era usado como uma pequena oficina onde Jandy tinha suas maquinas de costura. No momento da minha chegada, Jandy se encontrava costurando roupa de criança que venderia na madrugada seguinte na feirinha. Reparei também que estava gripada e com o rosto muito cansado, mesmo assim me recebeu muito contenta e começou a mostrar- 
me os espaços do seu apartamento, com muito entusiasmo começou a mostrar-me suas maquinas de costura, explicar-me para que servia cada uma e quanto lhe tinha costado consegui-las.

Antes de dormir, tomamos um pouco de café, na mesma mesa onde estava trabalhando, conversamos um pouco sobre sua família, sobre o Peru e as comidas de lá. deixamos toda a mercadoria pronta em sacolas grandes e as colocamos no carrinho que usa diariamente para levar os pacotes de roupa até a feirinha.

Essas três horas de descanso, dormindo em um lugar desconhecido, já deitada no colchão e com todas as luzes apagadas, foram de muita ansiedade para mim e ao mesmo tempo de muita expectativa por conhecer e descobrir o que veria algumas horas depois. A alarme soou as duas da manha. Para mim foi um martírio, para ela sua rotina. Era obviamente ainda de noite quando nos levantamos, senti que não havia conseguido descansar nada. Percebi esse dia que cansaço, sono e frio era o que caracterizava o cotidiano dos trabalhadores comerciantes nesses horários. Jandy e eu começamos a nos arrumar para sair, nos colocamos roupa bem abrigada, pois ela me sugeriu que a madrugada seria muito fria e devia de me abrigar. Saímos sem comer nada e lhe perguntei se pegaríamos algum carro para levar as coisas até o Brás, com o que me respondeu que não, que ela sempre ia caminhando arrastrando seu carrinho com a mercadoria e que, só tomava um taxi na volta já que devido a que voltava com tudo o dinheiro das vendas era melhor evitar assaltos frequentes que acontecem no caminho de volta a casa. Ademais, me falou que é melhor voltar de carro já que, pela dinâmica, acabam todos muito cansados e sem ânimo para andar transportando carga.

Foi assim que saímos da sua casa sentido Brás andando pela pista e arrastrando o pesado carrinho repleto de mercadoria de um lado eu e do outro ela. Nessa mesma rua e nas seguintes observei varias outras pessoas, inclusive famílias inteiras, saindo das suas casas com seus carrinhos levando a mercadoria para a mesma feirinha onde nos dirigíamos. Eu lhe perguntei Jandy por essas pessoas e ela me comentou que tem muitos outros comerciantes da feirinha morando perto dai, inclusive quase todos seus vizinhos eram comerciantes dessa feirinha e diariamente todos saem das suas casas nos mesmos horários de madrugada, cada um levando o seu carrinho, o que Jandy acrescentou que devido a isso é muito mais seguro para todos, já que ao ser varias pessoas evitam tentativas de assaltos e roubos que acontecem normalmente na região.

Assim, aproximando-nos às ruas onde se leva a cabo a feirinha, já podia se perceber a intensa atividade nessas áreas em plena madrugada. Multidão de vendedores 
chegando por todas as vias com sua mercadoria, os donos e encarregados das lojas de boxes abrindo e deixando pronto todo para a chegada dos compradores, os ambulantes de comida chegando apressados para conseguir instalar-se em algum lugar, vendedores de CDs de música chegando mostrando seu produto mais na moda a traves dos aparelhos de som com alto volumem.

Chegando à rua onde Jandy tinha seu ponto, comecei a notar grande presença de vendedores ambulantes de outros países, montando do mesmo modo suas bancas de venda, as quais eram basicamente umas mesas de madeira onde colocavam as peças de roupa, os manequins, algumas lâmpadas para alumbrar. Notei de imediato que a maioria de ambulantes peruanos e bolivianos se posicionavam na mesma rua, como si na feirinha diversas regiões estivessem destinadas para determinados grupos. Na rua onde eu fiquei acompanhando a Jandy, tive a oportunidade de conhecer outros comerciantes, principalmente da Bolívia, geralmente mulheres jovens e senhoras maiores cobertas com cobertores devido ao frio da madrugada e que, da mesma maneira que Jandy, comercializavam roupas de diversos modelos.

Aquele dia conheci duas pessoas que participariam na pesquisa meses depois: Cesar e Sara. Ambos me foram apresentados por Jandy, primeiramente porque Sara é sua sobrinha e Jandy já tinha comentado que tinha vários parentes peruanos que vendiam roupa na mesma feirinha só que algumas ruas de distancia. Cesar também foi apresentado por Jandy, no momento que chegou vendendo bebidas quentes de cereais peruanos. Cesar é um vendedor de comida conhecido por quase todos os ambulantes latino-americanos da feirinha devido a que é o único que vende café de manhas típicos da sua região em horas de madrugada.

Em um momento da madrugada passou um imigrante colombiano com um casaco muito grande, encarregado de fazer uma cobrança de dinheiro a vários imigrantes. Jandy me comentou que aquele rapaz realizava a função de prestamista, atividade praticada por muitos jovens imigrantes colombianos em São Paulo. No caso de Jandy, ela acudiu a esse rapaz colombiano porque precisava de dinheiro para comprar uma maquina de costura, assim como de certo capital para começar a comprar sua primeira mercadoria. Esses jovens passam semanalmente cobrando de banca em banca aos ambulantes aos quais emprestaram dinheiro, sendo que são os peruanos, bolivianos, paraguaios e equatorianos os clientes principais. Quando perguntei a Jandy por aquele rapaz que se aproximou ao seu ponto com um olhar serio, ela me respondeu que era o prestamista, e que sempre os prestamistas eram colombianos que também 
trabalhavam na feirinha, mas em outra situação, "nunca para vender, só para cobrar", e acrescentou que aqueles jovens trabalham para um prestamista maior, um capitalista dono de todo o dinheiro, também colombiano.

Andando pela feirinha de madrugada, pude reconhecer também grupos de diversas nacionalidades e geralmente sociabilizando só entre eles, tal o caso dos comerciantes equatorianos, facilmente reconhecidos pelos seus traços físicos e sua cabeleira comprida, vendendo pequenos acessórios geralmente sobre um tecido posto na pista. Outro grupo que consegui identificar foram os indianos, falando a língua deles e agrupados ao redor de alguns panos sobre o qual colocavam sua mercadoria. Aos chineses nunca se lhes encontra vendendo na rua, sempre são os proprietários de grandes lojas no Brás e geralmente, contratam funcionários brasileiros para trabalhar para eles.

\subsubsection{Narrativas dos e das imigrantes sobre o Trabalho na Feirinha}

\section{Harold}

"Aprendi sobre o negocio desde criança vendo o meu pai vender"

Eu cheguei no Brasil com um dinheiro que poupei trabalhando lá no Peru. Lá eu estava na minha casa, morava com meu pai, trabalhava no seu negocio, viajava, ia na Amazônia, ia para Chiclayo, para Trujillo, eu me dedicava ao negocio. Em junho, o mês que eu cheguei, não trabalhei, só fiz passear e conhecer amigos. Já depois a grana acabou e quis ir embora, também porque não gostei muito da cidade e na primeira semana já quis voltar para o Peru, mas como tinha 3 meses de passe livre no país decidi ficar mais um tempinho. Ai, meu tio me disse - "ajuda-me melhor a vender na feirinha de madrugada no meu negócio" - e foi assim como comecei a ajuda-lo na venda. Ai eu meio que me acostumei, fiz novos amigos, jogava futebol com eles longe de casa.

Trabalhei com ele ate dezembro, trabalhei também ajudando outros tios nos seus boxes, já em dezembro eu quis trabalhar só pra mim, comecei a me virar sozinho trabalhando desde abaixo. Lá no Peru, meu pai era comerciante e eu veia como ele fazia, como ele vendia. Meu pai dizia - vou comprar tanto, esta será a ganancia e isto vou gastar-. E eu prestava muita atenção quando o ajudava, eu escutava e veia o que ele 
fazia. E um dia quando eu parei de trabalhar com meu tio aqui, eu pensei - E agora, o que eu vou fazer? tenho que lembrar como meu pai fazia. Já sei! vou comprar uma mercadoria e vou vende-la a tal quantidade! -. No Peru eu não entendia muito meu pai, não entendia seus negócios, mas aqui eu saquei minha conclusão de como ele fazia e o repeti.

Eu tenho minha própria mercadoria de roupa, um brasileiro que me traz de Minas Gerais, lá é onde confeccionam roupa de verão, mas também aqui se produz muita roupa que se distribui pelo Brasil todo. Eu peço tudo por atacado, por exemplo, peço 300 peças de um modelo, 200 de outro. Isso tudo eu o guardo no meu quarto e vou pegando para vender, tenho tudo isso organizado e pronto para distribui-lo quando me fazem pedidos. Conheci a todos esses vendedores por contatos de meus primos e tios. Por exemplo, compro uma peça por 10 reais e a vendo por 15 ou 20 reais, ganho aproximadamente 6 ou 8 reais por peça.

"A vida de um estrangeiro aqui é difícil, a gente tem que trabalhar muito pra se manter"

$\mathrm{Na}$ rua, fora da feirinha, também às vezes vendo um pouco, mas principalmente trabalho na madrugada. Se você trabalha na feirinha de madrugada, às 2 da manhã você tem que estar acordado, em pé. Meu dia começa às 2 ou 3 da manhã, hora que eu acordo para trabalhar. Trabalho até as 8 ou 9, as vezes fico até as 10 da manhã, dependendo das vendas. Dai, volto para casa, tomo banho, como alguma coisa na lanchonete e durmo. As horas passam, amanhece e assim, de novo madrugara para trabalhar. Hoje por exemplo, trabalhei desde as 4 até as 9 da manhã. Depende também do dia, se tiver muitas vendas vou embora cedo, quando não tem venda tenho que esperar até conseguir vender. Dai volto para casa e descanso. Na tarde se você quer pode trabalhar em outra coisa, isso pode te dar mais renda. Eu só trabalho vendendo na feria, mas conheço pessoas que trabalham o dia todo, as 24 horas. Eu sinto que a vida de uma pessoa de fora aqui é difícil. A gente tem que trabalhar muito. Tem pessoas que não trabalham e não tem nada. Aqui se você sabe trabalhar tudo vai bem, você tem que trabalhar e mais nada. Aqui tudo é caro, a comida é cara, a roupa em fim é barata porque a gente se encarga, um quarto pequeno também é muito caro, custa 1000, 500, mesmo aqui no Brás. Tudo tem seu lado bom e seu lado ruim. 
Dizem que aqui em São Paulo a vida é boa, dizem né, eu não sei. Para um vendedor, trabalhar aqui é um pouco difícil. Na rua a policia te persegue, é proibido vender na rua e por isso eles te perseguem. E quando eles te pegam, prendem toda tua mercadoria e se você faz problema por isso eles botam você no calabouço. Eu acho que para todo mundo é igual, porém, como a gente é estrangeiro tentamos ser mais educados porque temos medo. Quando a policia pega um brasileiro, ele não se deixa, ele fala, grita, arma um barraco até ficar livre. Mas quem é de fora fica calado e mais nada, deixa para conversar só na delegacia porque sabe que se faz um escândalo a policia o manda embora do pais. Aqui o estrangeiro tem medo de ser prendido.

\section{"É a rua o que eles te vendem pra você poder trabalhar todos os dias"}

Aqui na rua tem também muita briga pelo espaço. E quem não lutaria por isso? "Este é o meu espaço". Os brasileiros reclamam sempre por seu ponto, acham que são os donos da rua. As vezes quando chego tarde na feirinha eu fico sem ponto para vender, e prefiro não brigar, então fico trabalhando em outra coisa. Tem um grupo de malandros, são grupos de 20 ou 30 pessoas que marcam ponto assim, na rua com uma linha branca, e esse espaço marcado é o que eles vendem, a 1000 reais, 500 reais! Eles vendem esse espaço para você poder trabalhar todos os dias nele. É a rua o que eles vendem, esse pedaço! E tem pessoas que compram esse pedaço, esse ponto, e ali mesmo trabalham todos os dias. Quando chega a policia todos esses malandros somem, se escondem. Tem alguns que são uns palhaços porque te vendem o ponto por uma semana e na semana seguinte chegam outros a encher o saco e cobrar. Eu nunca paguei. São 7 meses que ajudei meu tio a vender no seu box e só há dois meses que tive curiosidade por vender na rua e fui vender. Tem pessoas que pagaram... bolivianos tem pago, são uns otários. Porque eu vou pagar? se você se humilha não adianta, se você se deixa abusar uma vez, já era.

Aqui em são Paulo, os peruanos trabalham no comercio. A maioria dos que estão aqui no Brás trabalham assim, vendem, compram o revendem. São Paulo é maior, tem mais movimentação para o comercio, as pessoas chegam até de outras cidades para comprar. Aqui você pode juntar 20 mil ou 30 mil reais. No Peru para juntar toda essa grana você demora muito e aqui você pode começar com pouca grana um negocio, lá você precisaria de 40 mil, 50 mil para começar um bom negocio. Tenho amigos que, por exemplo, saíram na rua a vender e em um dia só eles ganharam o suficiente para pagar o 
aluguel do seu quarto. O peruano se movimenta mais. Lá, no Peru o problema é que tem muita competência, em Gamarra, por exemplo, a competência esta no tope. Aqui não é tanto assim, o brasileiro não sabe muito de comercio. Você vai ver mais chineses, peruanos e bolivianos e o comercio se move mais rápido por isso. se você ver, aqui eu acho que o peruano, o boliviano, o colombiano estão muito melhor que muitos brasileiros, economicamente, claro. Porque tem muitos brasileiros que não tem nada. $\mathrm{Ou}$ seja, que as pessoas são conformistas, são pessoas que se hoje ganham 100 reais, no outro dia já não trabalham. Eles (brasileiros) com 20, 30 ou 10 reais que tem no bolso já estão contentes. Eu acho que se deve à educação, você não acha? porque tem pessoas com educação e querem ser mais na vida, mas tem outros sem educação, não tem mentalidade positiva, trabalham só para o dia a dia. Dai quando a grana acaba eles entram na delinquência, roubam, fumam.

\section{“Muitos peruanos chegam e são explorados, depois conseguem ficar independentes e vender por sua conta."}

Aqui eu conheço também vários cozinheiros peruanos, que chegam para trabalhar nos restaurantes de comida peruana, eu conheço também os restaurantes, mas como falei, mais chegam para o comercio. No meu caso, por exemplo, um tio que mora aqui já queria me trazer aos 16 anos para trabalhar com ele. Mas no final acabei vindo por minha conta, para conhecer e agora trabalho para mim. Tem muitas pessoas que traem peruanos para trabalhar com eles, esses peruanos chegam e aqui são explorados, todas esses são explorados. Já depois eles "se abrem" conseguem ficar independentes e trabalhar, começam a vender por sua conta. Dizem por exemplo - quero três trabalhadores para o Brasil, eles vão ter quarto, comida e salario-. Então você pensa Brasil! - Eles vêm e aqui é outro mundo, você só tem que trabalhar e muito. Conheço muitas pessoas que vieram assim, tem muitos peruanos explorados assim. Mas quando o boliviano traz pessoas, ele os engana, ele lhes disse que vão receber salario e é mentira, não lhes pagam. 
Jandy

\section{“Eu sempre gostei de ser independente, ou seja, não me reger por}

horários, nem ter um chefe que mande sobre mim, nem ter que

server"

$\mathrm{Na}$ minha juventude, a primeira vez que fiquei em Lima trabalhei esporadicamente, eu sempre trabalhei assim. Trabalhava trocando dólares na rua, no Jiron de la Union, no centro da cidade. Como o dólar começou a cair, esse trabalho não era mais rentável, então o deixei e fui para Colômbia. Eu sempre fiz esse tipo de trabalhos, sempre. Nunca quis trabalhar para ninguém. Quando eu acabei a escola concursei para uma empresa de telefonia, a "Telefônica", mas não, não deu certo, lá é tudo por indicação. Eu tive companheiras que eram alunas muito ruins, não estudavam, mas eram elas que entravam nessas empresas, elas concursavam e entravam. Elas diziam "minha irmã trabalha aqui". E assim elas ingressavam. Eu pensava - "não adianta, vou perder meu tempo lá" -, mesmo eu sabendo contabilidade e tudo isso.

Desiludida eu disse - "não, se algum dia eu trabalhar, eu terei meu próprio escritório contável, sempre independente". Eu sempre gostei de ser independente, ou seja, não rege-me em horários, nem ter um chefe que mande sobre mim, nem ter que server. A única vez que trabalhei para outros foi na Colômbia. Mas eu tentava ficar o menor tempo possível, trabalhava lá costurando porque sabia que ia embora rápido. $\mathrm{Na}$ Venezuela também foi o único trabalho que se me apresentou, então tive que comprar minhas maquinas e trabalhar para uma empresa. Em fim, depois de um tempo que fiquei morando na Colômbia, eu voltei no Peru, fui morar de novo em Lima, lá acontecia que não havia muito trabalho, você sabe, problemas com Fujimori e os outros governos. Ate agora no Peru não tem muito trabalho. Tem professionais que são advogados, arquitetos e não trabalham na sua profissão porque não tem muito trabalho, eles são taxistas, comerciantes. Ou seja, eles se graduam e nunca conseguem trabalhar na sua profissão.

Eu também estive estudando arquitetura mas não consegui terminar porque como éramos cinco irmãos e minha mãe era mãe solteira, ela não podia educar-nos a todos, imagina ela sozinha! Então, depois de ver essa falta de oportunidade fui para Venezuela, eu já tinha quarenta e poucos anos e como costura era o que eu sabia fazer, me dediquei a costurar por lá também. Eu fui para Venezuela porque eu tenho uma irmã que mora lá.

ela tem uma empresa de eventos, uma agencia de festas. É uma empresa grande com 
vários funcionários, aluga material de evento de outras empresas. Então eu comecei a trabalhar costurando na empresa da minha irmã e foi bom. Também eu tinha vários sobrinhos morando lá em Caracas. O menino trabalhava numa agencia de eventos e minha sobrinha trabalhava vendendo coisas na rua.

Depois da Venezuela fui para Colômbia onde fiquei quatro meses. Esses poucos meses que eu fiquei por lá estive trabalhando em uma empresa de confecção de pijamas. $\mathrm{Na}$ real, eu nunca tinha me dedicado à costura. Eu me dediquei a costurar só quando fui embora do Peru, era o que melhor sabia fazer. Então me dediquei a isso na Colômbia e na Venezuela também. Mas a Colômbia também tem o mesmo problema que o Peru. $\mathrm{O}$ salario não dá, não alcança para ter uma vida cômoda, ou seja, você trabalha para sobreviver. Tinha também outra coisa, eu estava recém operada da vesícula e quando eu fazia esforço me dava febre. Deixava de trabalhar por uns dias para que minha ferida se desinflame e depois voltava a trabalhar.

Aqui no Brasil trabalhei muito desde o começo também. Quando eu vim, meu sobrinho já vendia na feirinha em Brás e ele me diz para eu ir trabalhar lá vendendo qualquer coisa. Aí eu pensei - "e agora, o que vou fazer? venderei comida então... mas eu não sei cozinhar! e agora?". Ele me diz "não tia, não da para a senhora fazer isso, o melhor é você comprar mercadoria e começar a vender". E foi assim que comecei a vender. Eu comprava mercadoria e vendia, comprava e vendia e assim... Mas eu queria ter uma maquina para trabalhar, falei para minha sobrinha que queria comprar uma maquina para eu mesma costurar e fazer minha própria mercadoria e vender. Aí ela me diz que conhecia um peruano que poderia me alugar umas maquinas. Depois de arrumar umas maquinas para costurar e cortar as peças eu comecei a trabalhar duro porque consegui um ponto para vender na calçada aí na feirinha de madrugada, então tinha que ir tudo dia seja como for! Se eu faltava alguém podia pegar meu ponto e não podia perdê-lo! Eu ficava vendendo na feirinha até as oito da manhã e dai ia direto a costurar naquele apartamento. Aí ficava trabalhando até as seis da tarde porque nesse tempo também estampava, costurava e ao mesmo tempo estampava as roupas. Voltava em casa só a noite para descansar um pouco. As pessoas me diziam - "nossa, você voltando a noite e sozinha desde lá, cuidado porque aqui tem assaltos, podem levar sua mercadoria, quanto tempo a senhora est aqui?"- Eu levava muito pouco tempo, há três meses que acabava de chegar. E assim eu trabalhava, com o tempo consegui comprar minha própria máquina de estampar e assim podia voltar mas cedo para estampar no meu quarto. Um tempo eu costurava, estampava e eu mesma ensacava até uma hora da 
manhã e as três eu já tinha que ir na feirinha! Quase não dormia! Estive como quatro meses trabalhando assim, não sei como aguentei. Juro que em dezembro descansei como três dias! Dormia, acordava para comer alguma coisa e dormia de novo, estava recuperando o sono! Como três dias seguidos fiquei assim. Comia e ficava dormida na mesa, então voltava para cama, dormia manha, tarde e noite. Eu estava cansada demais! Eu quase não dormia, trabalhando todo dia e madrugando para vender. Não dormia nada no dia porque continuava trabalhando. Dormia só duas ou três horas por dia e assim os quatro primeiros meses, desde setembro quando cheguei. Era demasiado! Nossa foi difícil. Eu pensava não vou aguentar! Mas mesmo assim consegui, não sei como, mas aguentei. Daí chegou minha irmã e ela me ajudava, ela vendia na madrugada e eu já consegui descansar um pouco. A gente voltava sempre sozinhas andando desde a Rio Branco e lembro que um dia fomos assaltadas aí nem mais, começamos a pegar taxi para voltar. Esse dia do assalto eu tinha me emprestado dinheiro dos colombianos, como 2000 reais, tinha pago uma mercadoria a uma amiga e fiquei com 1500 reais e isso era 0 que tinha no meu bolso. De sorte que os assaltantes não levaram meu bolso. Eles tentaram tirar o bolso do meu ombro e eu de novo me colocava a alça. E a minha irmã também! O assaltante tinha uma faca e corto a alça do bolso dela. Minha irmã me ajudou a defender do outro e começou a bater nele, então ele fugiu. Eu fiquei com raiva e falei para minha irmã - "por que você não soltou o bolso? você sabe que eu estou com o dinheiro aqui e pelo contrario você não tem nada no bolso mais que dois celulares!". No final os ladrões levaram só a bolsa dela com os dois telefones, ainda bem que não levaram o meu. Teve outro dia que também me assaltaram, eram três ladroes que me pegaram, na frente tinha outras pessoas, mas como eu estava indo sozinha atrás me pagaram e puxaram meu bolso. Por sorte eu não tinha nada porque guardei tudo dentro da roupa, meus telefones, meu dinheiro, tudo. Não levaram nada. Em fim, a gente agora volta de taxi, chamamos a uma vizinha que faz taxi e ela nos leva, mas para ir geralmente vamos andando desde aqui ${ }^{6}$ até a feirinha. Para mim essa parte é a mais perigosa, andar por essas ruas na madrugada porque te roubam a mercadoria na ida e na volta te roubam o dinheiro que você fez. Mas... mesmo assim, eu já estou acostumada a trabalhar na rua. Eu não acho que seja tão perigosa, pode ser perigosa para algumas pessoas. Mas mesmo assim não acho, porque nesse horário, que a gente sai de casa para trabalhar tem muitas pessoas por perto, muitos moradores daqui que saem também a

\footnotetext{
${ }^{6}$ A entrevistada faz referência à zona onde ela mora, isto é, nos arredores da Estação da Luz.
} 
vender em outras feirinhas, como na rua 25 de março. De mais para cima tem muitas pessoas também, que trabalham de madrugada, você vê muitas pessoas sair dessas casas e descer andando pelas ruas até as feirinhas. Agora tento ir mais cedo, porque esse dia do assalto eram mais das 4 da manhã e nesse horário já tem ladroes nas ruas, debaixo da ponte. As duas da manhã, duas e meia é muito tranquilo andar na rua. Às vezes também tem viaturas da policia dando voltas. Então o perigo é só para chegar porque uma vez que você esta lá, na feirinha, tudo é muito tranquilo. Aí não tem perigo, você vai e trabalha, é como ter um negocio dentro, uma banca dentro, trabalha-se igual.

Esta é a primeira vez que trabalho assim, eu nunca trabalhei de madrugada. Eu era tão dormilona! E agora olha como estou, sinto até que envelheci demais. Mas daqui a umas semanas vai chegar uma sobrinha minha que mandei chamar, ela sabe costurar então virá para me ajudar. Justo ontem a noite essa sobrinha me enviou uma mensagem perguntando como iam as coisas por cá. Despois ligou como à meia noite e falamos um pouco, me perguntou como ia o trabalho, eu falei que estava tudo bem, mas que estavame sentindo um pouco doente pela quantidade de trabalho que tinha. Aproveitei para contar-lhe que estava pensando trazer uma pessoa de Peru para que me ajude. Aí ela me diz que justo estava querendo vir para o Brasil, então combinamos assim, que ela chegaria em outubro para me ajudar a trabalhar. Acho ótimo porque nessa época começa a temporada alta e a gente precisa trabalhar muito. Aliás eu posso trabalhar tranquilamente três dias, quatro dias seguidos, mas se começo a forçar muito começa a dor nas costas. Agora por exemplo, estou sentindo-me um pouco doente porque tenho estado trabalhando muito. Com essa maquina que esta aqui, tenho cortado muito desde ontem. Eu sozinha consegui cortar 2000 peças em dois dias. Depois estas peças mando costurar com uma amiga boliviana que me entregara toda a mercadoria na sexta. Sexta e sábado já posso começar a vender essa roupa e na segunda já terei acabado de vender tudo. Com o dinheiro que ganho já posso lhe pagar. É a primeira mercadoria que faço nesse modelo, porque o tempo esta começando a mudar e as pessoas não compram mais roupas de inverno. Então vou começar a costurar shorts e coisas mais de verão, minha mercadoria é mais roupas de criança.

Mas tem muitas pessoas fazendo esse tipo de trabalhos, pessoas que trabalham sozinhas e também tem muitos casais. Nesse quarteirão onde eu estou tem muitos bolivianos, peruanos, colombianos, paraguaios, brasileiros. Os peruanos preferem sempre trabalhar por sua conta. Por exemplo, meu sobrinho chegou e estava procurando um emprego. Ele começou a trabalhar em um restaurante porque como farmacêutico é 
difícil. Ele tem que convalidar e além de tudo ele não sabe o idioma muito bem. Então ele começou a trabalhar em um restaurante peruano, mas o dono não lhe pagava ou lhe pagava por partes. Ele me contou que nesse restaurante vendem bastante e ganham muito dinheiro, mas o dono paga assim aos empregados. O dono não demite eles... eles sozinhos vão embora porque não recebem salario. Eu acho que é por isso que os peruanos preferem ser independentes e trabalhar na rua. No caso dos bolivianos, eles geralmente têm suas oficinas, fazem serviços de costurar ou cortar a mercadoria dos outros, as vezes eles mesmo vendem também. Os colombianos, a maioria, emprestam dinheiro, quase todos trabalham emprestando dinheiro. Mas esses colombianos são empregados, o dinheiro não é deles, tem um capitalista que lhes da. Suponho que lhes deve dar um salario para eles trabalhar disso. Os chineses não vendem na rua, eles têm suas grandes lojas. Tinha um chinesinho que passava vendendo comida. Ele vendia bolo com suco, e tem outro chinesinho que passa vendendo... soba... como é? Yakissoba. Isso! yakissoba. Eles vendem isso todos os dias, assim caminhando, mas não tem um ponto fixo. $\mathrm{Na} 25 \mathrm{sim}$ tenho visto chineses vendendo na rua. É que tem uma outra feirinha de madrugada na 25 de março e lá dizem que a maioria são peruanos e chineses. Mas eles vendem um pouquinho mais tarde, como às 4 da manhã. Eles vão ás 4 e ficam só até as 6 da manhã. Tenho uns sobrinhos bem jovens que trabalham por lá, , eles têm três lojas agora e estão planejando comprar-se uma casa, um lugar para morar. Mas estão esperando porque agora esta tendo muita competição, muita oferta. Antes por exemplo eles eram os únicos que vendiam mochilas nesse shopping na 25, agora quase todos os vendedores desse lugar vendem mochilas. Outros bolivianos e peruanos desse shopping se deram conta que meus sobrinhos vendiam bastante e agora todos vendem a mesma mercadoria. E tem muita disputa nesse shopping por isso, os outros fazem a guerra aos meus sobrinhos porque eles vendem mais. Mas agora com tanta oferta eles tem que ficar ligando aos clientes, oferecendo pelo telefone as novidades e até enviando a mercadoria sem cobrar o envio. Mas mesmo assim eles estão muito melhor que no Peru. Lá o negocio não vá muito bem, não se vende tanto quanto aqui. aqui a economia se movimenta, mesmo as pessoas falem que aqui não tem trabalho. Minha irmã, por exemplo, quando veio a trabalhar comigo ficou surpreendida de ver que o negocio aqui funciona. Aqui você não precisa oferecer a mercadoria, você fica sentado e as pessoas chegam e compram. Pelo contrario, no Peru, os vendedores oferecem, brigam para vender, tem muita competição. Minha irmã quando voltou agora no Peru, ficou vendendo na rua e me falou que as coisas por lá não vão muito bem, tem poucas pessoas 
comprando, as vezes você consegue vender, mas mesmo assim muito pouco. Tenho um amigo com quem eu trabalhava no Peru, a vida toda ele tem trabalhado vendendo na rua, viajando pelos povoados, pelas cidades. Me contou que esta temporada não consegue vender, as pessoas não compram e para conseguir levar um dinheiro para casa ela tinha que vender muito barato sua mercadoria. Agosto e setembro são temporadas muito baixas, as pessoas não têm dinheiro para comprar. Aqui, pelo contrario, você vende e vende e vende, as pessoas compram muito e dependendo da zona você vende por unidade como na Celso Garcia, ou por atacado, como na feirinha.

Aqui em São Paulo as pessoas compram bastante. Aqui as pessoas estão acostumadas a comprar até de madrugada, inclusive chegam muitos carros e ônibus de diferentes lugares trazendo pessoas para comprar, nessa hora da madrugada. Nas quintas chegam ônibus trazendo pessoas do interior. Já os outros dias vem ônibus trazendo pessoas daqui mesmo, chegam muitos carros e ônibus e ficam no estacionamento da feirinha. Eu não sei de onde vem umas pessoas que chegam com pouca roupa, com blusinhas finas em pleno inverno, eles chegam e compram, compram e daí vão embora no mesmo ônibus. No Peru não é assim, lá você vende só de manhã, aqui as pessoas vendem e compram de madrugada, por que será assim, né? Será porque nesse horário as pessoas chegam de longe? então tem que aproveitar o tempo para comprar porque esse mesmo dia já estão voltando.

\section{“Contratamos seguranças para nos defender dos brasileiros”}

Aqui no Brás a maioria de quarteirões estão ocupados por brasileiros. A gente tem muitos problemas com os brasileiros, eles são maus. Eles andam tirando aos bolivianos dos seus pontos. A gente paga semanalmente aos seguranças desse quarteirão 50 reais. Esses seguranças a gente contratou para nos proteger de uns bandidos brasileiros que acostumavam a tirar às pessoas dos seus pontos. Eles chegavam assim, antes de você chegar no teu ponto, eles colocavam um plástico azul sobre o lugar onde você vendia, aí na rua, e aí eles falavam "se você quiser vender aqui vai ter que pagar, você tem que me dar 100 reais por metro" Então a gente não podia fazer nada, as pessoas tinham que pagar, do contrario, eles entregavam esse ponto para outra pessoa que pague. Aconteceu que esses brasileiros tentaram fazer isso na nossa rua, no nosso quarteirão, mas a gente contratou esses seguranças. A partir de todos esses abusos a gente tem se organizado. Na real, são os bolivianos como eles são maioria, eles tem se 
organizado. Nesse quarteirão a gente tem feito uma cooperativa e é um peruano que esta de presidente. Engraçado porque sendo os bolivianos quem organizaram isso, no final é um peruano que esta dirigindo a associação. Eles dizem que escolheram ele porque é quem melhor sabe falar. Essa, nossa associação, já esta reconhecida pela prefeitura, a gente apresentou um papel com a assinatura de todos. Chama-se Associação de camelones de São Paulo, e fazem parte peruanos, bolivianos, de qualquer país, inclusive brasileiros, mas todos somos camelones, ou seja, vendedores ambulantes. Camelones chama-se aqui. Eu quando escutava isso dizia- "o que será isso". Me perguntavam "você tem visto os camelones? Tem bastantes camelones na rua?" - E eu dizia “camelones? sim, sim tenho visto". Mas eu não sabia o que era isso. Já depois perguntei para minha sobrinha o que era isso de camelones e ela me diz "somos nós, tia, as pessoas chamam a gente de camelones, a quem vende na rua". Na Venezuela chama-se buaneros, no Peru chama-se ambulantes.

Em fim, a gente esta organizada. Especialmente porque com isso da associação a gente tem mais direitos. Então os bandidos não podem mais fazer isso conosco porque vamos todos da associação a prestar uma queixa à prefeitura, mas agora de maneira legal. Agora podemos reclamar sobre os abusos. A gente tem quase um ano. Agora podemos vender sem a policia correr traz da gente. Depois de muita luta, no final nos deram autorização para vender. Chegaram até lá os cônsules, muitas pessoas foram falar com a prefeitura para que nos deixem vender, porque somos quantidade! E agora esta aumentando o número de camelos aí. A prefeitura agora nos deu umas bancas de madeira para vender, porque antes a gente vendia no chão. Agora esta muito mais organizado. temos um horário, de duas da manhã a sete e meia da manhã como máximo. e podemos ficar tranquilos até esse horário. Depois de nós outros já podem começar a vender, como os shoppings. É que em nenhum país vão deixar as pessoas vender na rua, por isso eles não deixam vender na madrugada porque não interrompe o transito, não tem carros. Mas a partir das sete da manhã começam a aparecer os carros, mais pessoas e a gente tem que ir embora. Mas tudo bem, porque até essa hora todos os comerciantes já temos conseguido vendido o suficiente.

Em quanto às relações com os outros camelones estrangeiros, eu acho que é tudo muito tranquilo. Com os únicos que temos problemas são com os brasileiros, eles sempre querem pegar um espaço maior. Eles não pagam aos seguranças, todos nós pagamos, menos eles porque estão no seu país, eles dizem assim- "não, eu não pago porque estou no me país". Os encarregados da feirinha nos têm reduzidos a cada um, 5 
centímetros para fazer uma passagem. E os brasileiros não querem, eles não se deixam reduzir seu espaço, só porque são brasileiros. Eles também são abusivos. Me disseram que uma senhora brasileira tinha falado para uns camelos de um quarteirão que a prefeitura deixaria todos eles venderem nesse espaço pelo pago de 10000 reais. Imagina! 10000 reais ela pegou dessas pessoas a acima de tudo parcelado! De um dia para outro ela apareceu com um negocio grande aí no Bras. Estava claro! Você acha que a prefeitura cobraria essa quantidade para deixar vender? esses bolivianos são uns trouxas! Ela os enganou, nesse quarteirão, são todos bolivianos. E assim eles lhe deram o dinheiro para ela pagar à prefeitura. Olha só, como essas pessoas são trouxas! Os brasileiros estão acostumados a enrolar os bolivianos, os brasileiros andam tirando do ponto aos bolivianos e eles, coitados, vão embora.

Nós temos que brigar muito pelo ponto. Você tem que brigar mesmo porque não tem nenhum espaço livre. Eu por exemplo peguei esse ponto porque minha sobrinha me deu um espaço pequenino do lado dela para eu poder vender. Mas não era um pedacinho, era um espaço grande! Porque nessa época você podia pegar um espaço grande, ninguém brigava pelo espaço porque não estava permitido vender na rua. Então os comerciantes chegavam e todos pegavam um espaço qualquer para vender. Uma peruana viajou e deixou o seu espaço para minha sobrinha, era um espaço grande! Então, minha sobrinha me deu um pouco do seu espaço para eu poder trabalhar aí. Com o tempo, outros ambulantes iam se colocando aí mesmo, do lado ou no mesmo espaço um juntinho do outro. Como eu não sabia, não falava nada porque nesse tempo ninguém brigava. Mas agora a gente vende o espaço! Só por esse pedacinho que eu cedo a uns bolivianos, eles me pagam mais de 500 reais. É um negocio! porque se vende mais fora do que adentro do shopping e dos boxes. Esse lugar é uma mina de ouro, quando você tem mercadoria vende e não para de vender.

Tem uma outra senhora boliviana com quem eu divido meu ponto. Eu alugo um pedacinho do meu espaço para ela por 100 reais semanais. Eu estava com lastima dela porque a coitada não tinha ponto para vender, então tinha vezes que eu chegava tarde a trabalhar, como as 4 da manhã e antes disso ela ficava no meu ponto vendendo, e vendia muito bem! Vendia bastante. Mas quando eu chegava, ela ia embora e não podia vender mais. Porque se você não tiver ponto não pode vender, como você vai vender? na mão? não, não da para vender assim. Então um dia eu falei para ela "você pode vender aqui mesmo, não precisa ir embora”. E na real, eu não tinha interesse em receber algo dela, eu nem pensava cobrar. Mas parece que ela ficou um pouco envergonhada de ficar no 
meu ponto e cada vez que podia me queria convidar alguma coisa, ela queria agradecerme com alguma coisa, então cada vez que podia tentava me dar comida, café. Mas eu sempre a rejeitava porque eu dizia "se eu dou algo para ela não é porque vou receber alguma coisa". Então teve dias que eu não ia porque ficava costurando ate a madrugada no prédio, e quem ia era minha irmã com uma sobrinha que veio do peru. Um desses dia, a boliviana diz para minha irmã que queria que eu alugasse um pedacinho do meu ponto para ela, que ela queria me pagar por um pedacinho. Aí eu falei para minha irmã "se ela quer pagar então tá bom, cobra-lhe 200 reais". Porque isso era o que cobravam por um pedacinho, até mais, normalmente cobravam 250 reais. Então um dia que eu fui, a boliviana me diz se podia me pagar só 100 reais, então eu aceitei. E assim ela vende do meu ladinho, mas me ajuda muito. Quando eu não podia sair da ocupação porque não me deixavam e nem minha sobrinha nem minha irmã estavam eu não conseguia chegar na feirinha. Então essa amiga boliviana pegava minha mercadoria, a colocava na banca e vendia por mim também, legal. Ela me ajudava a vender minha mercadoria. Ela é uma boa pessoa, é uma grande ajuda. As vezes ela não me paga, por exemplo já são três semanas que ela não me paga. Mas ela quando não tem dinheiro me paga com sua mercadoria, então eu começo a vender a mercadoria dela e assim me cobro.

E assim a gente se ajuda, mas tem também bolivianos muito maus, os mesmos bolivianos são egoístas entre eles. Por exemplo, onde eu vendo, tem um dirigente boliviano malvado que nos queria mandar embora sempre. esse boliviano sempre vinha reclamar - “este não é o ponto de vocês! Vocês deveriam estar mais para lá!”. E assim a gente começava a brigar com ele, pedindo para ir embora- "esse não é problema seu! E vá embora!". Naquela época ele não era nada, ninguém era nada, ninguém tinha poder a mais, mas esse senhor boliviano vinha desde o outro lado, que era seu ponto, a nos reclamar, desde então esse boliviano nos tinha bronca.

E essa situação com ele empiorou um tempo depois quando todos já nós éramos obrigados a pagar pela segurança. A gente é obrigada a pagar toda segunda e terça feira aos seguranças, que são policias em retiro. Mas teve um dia na semana que eu e minha sobrinha não conseguimos ir trabalhar na feirinha porque estávamos mudando de casa. Então a gente não conseguiu pagar esse dia e a gente ficou devendo uma semana. $\mathrm{Na}$ semana seguinte, esse mesmo boliviano malvado veio nos reclamar do por que não tínhamos pago essa semana. Minha irmã diz para ele - "amanhã eu vou pagar, hoje ainda não consegui vender e não tenho dinheiro para te dar, amanhã eu pego". Então o boliviano escreveu no seu caderno amanhã e assim, a gente se comprometeu a pagar na 
terça. $\mathrm{O}$ que aconteceu foi que esse dia a gente não conseguiu acordar a tempo. $\mathrm{O}$ alarme estava atrasado... e o relógio também! (risos). Minha sobrinha nos ligou desesperada- "que horas vocês vem?! Outros ambulantes tem ocupado seu ponto!" Nossa! Eram as três da manhã e a gente continuava dormindo! Minha sobrinha ligava como maluca e a gente não respondia, pensávamos que era media noite ainda! (risos). Ligavam e ligavam, pensávamos que eram da TIM (risos). Quando contestamos minha sobrinha nos diz que nosso ponto tinha sido ocupado!. A coitada estava sozinha brigando com os outros vendedores. A gente se levantou rápido, nos vestimos, pegamos um taxi e fomos ver. Quando chegamos vimos que tinham outros vendedores em nosso ponto! Nos disseram que eles tinham pago e como a gente ficou devendo essa semana aos seguranças, a gente tinha perdido o ponto. Então aí começou a briga, uma gritaria maluca. Quem são eles para tirar-nos do nosso ponto?! Eles não são ninguém! A gente só estava devendo uma semana aos seguranças, a gente ia pagar esse mesmo dia! Nossa, se armou um barraco, estava tudo mundo lá. Os seguranças já tinham colocado no nosso ponto a dois bolivianos e a um brasileiro. E foi aquele maldito boliviano, o dirigente, que nos delatou e foi ele quem colocou um brasileiro! E o pior é que os brasileiros, se eles pegam um lugar já não querem sair mais! Diga-me, é para isso que se organizam? é para ter organização ou fazer bagunça? uma boliviana que já estava em nosso lugar não queria sair daí. Ela disse - "não, não! Não quero saber de nada, o segurança me colocou aqui mesmo!" - e o segurança nem olhava para ela (risos). A gente disse para ela - "não senhora, sinto muito, mas este é nosso ponto!" E acima dela colocamos nossa mercadoria, e acima do brasileiro também, nos colocamos aí. O brasileiro tampouco queria sair do nosso ponto, Claro! eles são piores porque se acham com mais direitos. Eu disse para ele “não! O senhor vá embora agora!” E ele não queria sair! e diz “eu não vou embora, você que tem que ir embora para seu país! vá embora! Vocês não pagam imposto!" Assim começamos a brigar, eu gritei “eu não quero saber de país nenhum, eu vou ficar aqui e quero meu ponto! E a gente paga mais impostos que vocês!’. Nossa, foi uma doidera, tudo mundo discutindo aí. No final as duas bolivianas foram embora, mas ficou o brasileiro teimoso. Assim que eu disse para ele "escuta, hoje você vai ficar aqui, hoje você pode ficar, mas amanhã não. Este é meu ponto, onde eu trabalho e você não vai tirar-me do meu ponto”. Dai vieram os responsáveis por pagar aos seguranças e ele tentou pagar. Aí eu falei “eles não vão pagar porque este ponto é meu, ele não vai pagar”. E assim não deixamos ele pagar e fui eu quem pagou por esse pedaço. 
Do meu lado, também tem uma menina boliviana que vende bem, ela também pagou rapidinho para não deixar ele pagar por nosso ponto. A essa menina minha sobrinha tinha vendido um pedaço por 2000 reais. Barato! Quando todos pagavam 5000, ela vendeu só por 2000, barato! Uma vez que você compra esse pedaço significa que você é o dono, esse já é teu ponto e você pode ficar aí. Eu vendo esse pedaço e a pessoa já fica dona. É assim, os espaços são vendidos. Ouvi dizer que estão pagando até 3000 reais. Você tem ideia de quanto custa uma banca dentro do shopping? custa mais de 10000. Desse valor a 3000... é nada! E lá fora é uma mina de ouro, vale ouro esse quarteirão, tudo mundo quer ficar aí. E assim, vende-se o ponto. Esse quarteirão é muito disputado, tem até seguranças. Nos outros quarteirões não é assim, então os brasileiros malandros chegam e tomam o ponto. Eles pedem 1000 para você poder vender nesse lugar, eles vendem seus próprios pontos. Em outro quarteirão tem outros brasileiros que cobram 150 reais semanalmente a cada ambulante. Aí os brasileiros alugam os pedaços às pessoas. Mas onde eu estou não é mais assim porque estamos organizados. E temos segurança, são 6 seguranças que a gente paga. Inclusive, chegaram uns brasileiros e falaram para nossos seguranças que a gente devia pagar para eles semanalmente 30 reais. Ou seja, além dos 50 reais que pagamos cada semana aos seguranças, cada um de nós deveria dar mais 30 reais para eles. Então os seguranças lhes disseram aos dirigentes o que estava acontecendo e nos reuniram a todos para nos dizer que em caso de a gente ver esses malandros tentando cobrar, todos deveríamos ir a ajudar e defender a esses vendedores, para que os malandros vejam que a gente não esta só. Esses malandros também andam armados, mas já se deram conta que nesse quarteirão não podem mais fazer isso, então eles não mexem mais conosco.

Mesmo assim, todos os camelones preferimos vender na rua, vende-se mais rápido. Lá dentro é impossível, você pagaria muito para poder ter uma banca dentro, uma milhonada de grana que a gente não tem. Alias, vende-se mais na rua. Por isso os vendedores de shopping andam reclamando, eles até dão propinas à policia para tirar os camelos da rua. Mas a gente fica só até certa hora, depois eles podem ficar até a hora que quiserem vendendo. Os camelones vão embora para os de dentro vender... a gente vai embora até o dia seguinte na madrugada. E na madrugava vende-se muito bem! As pessoas sabem que a gente vende mais barato, por isso vão de madrugada para comprar e como sabem que a gente fica só até cedo, então eles vão cedinho de madrugada para encontrar-nos. Antes os clientes chegavam quando a gente já estava indo embora, mas agora já sabem e chegam mais cedo. 
Tem rumores que vão tirar a gente da feirinha, então vamos ter que sair daí. Minha sobrinha me propus alugar um box, montar um negocio dentro de um shopping, ou vender do jeito que vendo, mas com mais tranquilidade, sair da rua e ficar num lugar mais tranquilo. Essa é a ideia né... estar melhor, formalizar-se. Mas tudo isso custa muito, muito dinheiro que eu não tenho agora, então isso pode ser mais pra frente. Trabalhar de madrugada é muito cansativo, você não tem vida... mas, por em quanto é isto o que a gente tem. Com quase todos os peruanos que trabalham de madrugada é assim, eles mesmos também me dizem que não tem vida, que isto não é vida... que se sentem cansados e querem voltar para o Peru e trabalhar lá. É o fato de trabalhar de madrugada... e olha que tem alguns que não costuram, eles só compram mercadoria e vendem. Eu costuro e vendo, tenho o trabalho de ir comprar os tecidos, costurar, vender. Agora não estou mais costurando, mas mesmo assim tenho que separar o tecido e cortar para mandar depois a costurar. Esse é um trabalho muito matado, isso mata a qualquer. Mas é o que dá dinheiro, né... se não se faz isto o que se faz?

\section{Cesar}

"toda minha vida trabalhei vendendo na rua como forma de ajudar minha família”

Eu toda minha vida sai vender na rua, desde criança minha mãe me enviava a vender comida na rua para ajudar em casa, vendia buñuelos, picarones, gelatinas, tamales, humitas. Quando era criança a gente colecionava cocos fazíamos cocadas e as levava para vender na escola. Quando jogava futebol eu não tinha dinheiro para apostar e apostava com cocadas. Eu vendia naquela época a 50 centavos cada uma, naquela época 50 centavos era como ganhar a copa do mundo! Era muito! Até agora eu valoro muito 50 centavos porque a gente sofre para ganhá-los. Bom, depois no final de tarde eu voltava para casa e entregava a minha mãe o dinheiro das vendas, a gente fazia contas, depois eu ia fazia minhas tarefas da escola e dai dormia. Na adolescência quando a gente voltou na cidade depois do conflito armado eu comecei vender gelatinas e minha mãe conseguiu um novo lugar para vender no mercado modelo. Quando eu vendia humitas também era legal porque eu vendia no meu bairro, nas casas dos meus amigos. Minha mãe me colocava um cesto de palha e pronto, me mandava a vender. Às seis da 
tarde eu voltava para casa para comer e fazer minhas tarefas. Eu não gostava que minhas irmãs saiam para rua a vender, eu era o único homem em casa e eu não gostava que elas saiam porque a rua era perigosa para elas.

Na temporada de inverno eu vendia comida, mas no verão vendia marcianos (geladinho) e foi um pouco difícil porque os vendia a 10 centavos, então eu vendia 30 marcianos e não ganhava nada, não compensava. Por isso foi que depois decidi vender gelatinas que minha mãe preparava, já com essas vendas a gente cresceu muito porque eu vendia 80, 90 unidades por dia e a 50 centavos, já compensava. Eu também vendia fruta, pegava a fruta que minha mãe vendia no mercado e a repartia a nossos clientes. Eu ajudava a minha mãe a escolher as frutas, acomoda-as e leva-as para a barraca no mercado, e tudo isso até a hora do café da manha. As vezes também eu comprava chocolates e os revendia numa avenida principal da cidade, mas essa ganancia era para mim porque era eu quem comprava as caixas de chocolate. As vezes passavam meus amigos e me veiam vendendo, vinham a tirar onda da minha cara, riam de mim, mas me esperavam a que eu terminasse de vender e me diziam - "bora! Bora jogar futebol!".

“O maior problema no Peru é que se trabalha muito e se ganha muito pouco!"

Já na juventude quando terminei a escola fui a Lima para trabalhar, mas não consegui ficar, mas que dois meses. Trabalhei numa oficina de costura em Gamarra, eu era basicamente ajudante, alcançava fios e outros materiais de costura aos costureiros, e colocava em sacolas as blusas e roupa que saia. Lá me pagavam 60 soles semanalmente, mas não me alcançava para viver! Era muito pouco! Por isso tive que voltar para cidade onde estudei cozinha. Esse é o maior problema no Peru, lá se trabalha muito e se ganha pouco. Não existem nem benefícios nem direitos laborais. os estudantes sempre são explorados, são poucos os praticantes que conseguem uma ajuda ou trabalhar de uma maneira justa. O que acontece é que no Peru tem muita competência, a oferta de cozinheiros é altíssima, então os donos dos restaurantes pagam o que eles querem e as vezes nem pagam. São poucos os restaurantes que pagam o justo. Por exemplo, no ultimo restaurante onde estive trabalhando lá sim me pagavam o que me prometeram e até recebi benefícios. Eles também me financiaram um pouco minha viagem para o Brasil. Eles me ajudaram para eu vir para cá. 


\section{Eu vim sem saber que iria a vender na rua, se eu tivesse sabido}

não teria vindo!"”

Acontece que eu já tinha um conhecido que estava morando aqui, eu conhecia ele de Lima. Aqui ele vendia comida na rua, mas isso eu não sabia. Quando eu estava trabalhando no ultimo restaurante me ligaram daqui do Brasil para que eu venha a trabalhar supostamente num restaurante. O tio da minha ex-esposa me falou que aqui conhecia um rapaz que estava precisando de dois cozinheiros. Ele lhe passou meu contato e foi assim como esse rapaz, a quem eu conhecia de vista em Lima, se contatou comigo e me diz- aqui tem trabalho, tem chamba no Brasil, vem para trabalhar comigo num restaurante, te animas? E eu lhe respondi que sim. Falei com o dono do restaurante onde eu estava trabalhando e lhe pedi 15 dias porque iria para o Brasil. Falei também com o encarregado do suposto restaurante aqui para lhe avisar que chegaria em 15 dias. Foi assim como cheguei em São Paulo, esse meu amigo me recebeu e fomos na casa dele numa ocupação para descansar. No dia seguinte eu preguntei para ele - "onde fica teu restaurante?"-. Ele me respondeu "tranquilo, ás 5 da tarde a gente vai para lá". A tarde ele me levou num apartamento onde ficamos cozinhando, eu continuava pensando que iriamos depois no seu restaurante. Dai colocamos toda a comida em marmitas e dai em esses carrinhos para vender, fomos na rua e ai ele me diz - "é aqui mesmo onde eu trabalho". A gente ficou em uma esquina da Rua Guaianases com Aurora, colocamos um guarda-chuva grande acima do carrinho e começamos a vender. Eu fiquei surpreso, mas ele me explicou que estava começando o seu negocio na rua e que depois, com o tempo, alugaria um lugar para montar um restaurante. No começo eu fiquei muito preocupado por ter ido embora do Peru para trabalhar vendendo na rua, mas com o tempo me acostumei, fiquei quase oito meses trabalhando assim. Comecei trabalhando com esse amigo e morando junto, fizemos uma sociedade e trabalhávamos vendendo comida na rua, na frente e do lado de restaurantes peruanos, só que a gente vendia mais barato, como a 10 reais o prato de comida. foi um bom negocio para gente, nos foi muito bem e era muito tranquilo trabalhar na rua, menos quando chegava a policia e você tinha que fugir e se esconder para que não levem teus carrinhos. Os donos dos restaurantes começaram então a baixar um pouco suas vendas e veio um dono e propus ao meu amigo trabalhar com ele. Como meu amigo já estava cansando de vender na rua aceito e foi com ele. Falou um dia para mim - "bem, até aqui chegamos" - Me deixou só nesse negocio. Quando agente se encontre sempre lembramos dessa época, vivíamos 
trabalhando e passeando nos shoppings, éramos felizes, ganhávamos muito bem, tínhamos muitos clientes, peruanos africanos, colombianos, chilenos. No dia mais baixo fazíamos 150 reais na hora de almoço. Esse meu amigo tinha uma ambição, ele queria ter vários restaurantes na cidade, mas não mediou seus gastos e fracassou. Eu vi a ambição dele, tempo depois ele abriu um local aqui, outro lá, mas não financiava o pago dos meninos cozinheiros. Pagava a metade ou não lhes pagava, foi assim como caiu e acabou fechando o local. Quando nos separamos eu me fui por meu lado. Como eu já tinha experiência com as compras, já sabia onde ficavam os mercados e as coisas para comprar, foi mais simples. Assim eu comecei a vender sozinho. Primeiro fui na feirinha de madrugada no Brás, saia vender tudo dia as cinco da manhã. Como eu já tinha um quarto numa ocupação, cozinhava lá mesmo e depois saia a vender.

Os primeiros meses que vendia na feirinha de madrugada foram um pouco difíceis. Daí parei porque comecei a trabalhar para outros peruanos aqui que tinham seu restaurante de comida peruano, trabalhei como em três. $\mathrm{O}$ primeiro num restaurante de um casal de peruanos aqui na rua Rio Branco, daí fui em outro restaurante de um amigo e daí a outro restaurante na Paulista.

Quando eu trabalhava aqui no restaurante, nesse tempo sim exploravam. Eu trabalhava 10 horas e as vezes mais. Uma vez o dono me diz "fica mais tempo e eu te pago". Eu fiquei mais 5 horas cozinhando e no dia seguinte cobrei, o dono me deu 20 reais. Eu falei para ele "o que é isto $\square$ é gorjeta $\square$ ”. o dono me diz que pagava 5 reais a hora. Imagina, 5 reais! No dia seguinte ele ordenou para mim ficar na cozinha, eu rejeitei e diz para ele "não, eu não vou ficar e o senhor não pode me obrigar". Ele tentou me insistir para eu ficar dizendo que todos os outros cozinheiros ficavam também. Falei para ele que não e que seria melhor que procurasse um cusqueño o alguém dos andes que aceite ser explorado. O dono ganha em um só prato grande de ceviche 120 reais, com toda a grana que ganha dá para pagar bem aos seus funcionários. É que muitos não reclamavam isso, eu sim reclamava. O dono faz os cozinheiros ficar mais tempo na cozinha e não paga ou paga muito pouco. Ou seja, eu me matei estudando, me sacrifiquei estudando para que ele me pague 5 reais? eu estudei cozinha, eu não sou aprendiz nem ajudante de cozinha. Ele tem que me respeitar. Eu entendo que ele tinha vindo de Huancayo, desde lá os Andes onde passou necessidade, mas isso não justifica que ele explore pessoas.

O que acontece é que tem um método aqui. Naquela época era assim, eu não sei como será agora. Mas antes os donos tinham o método de ir à estação Tiete aonde 
chegavam muitos jovens peruanos, geralmente de povoados pequenos dos Andes e aí os donos ofereciam trabalho de ajudante de cozinha para eles. Então chegavam, trabalhavam quase todo o dia e o dono lhes pagava o que ele queria, as vezes nem pagava. Mas como eles estavam aqui sozinhos sem conhecer a ninguém não faziam nada. Depois tinham outro método os donos, eles iam para Lima, chegavam nas escolas de cozinha onde tinham meninos estudando. Os donos falavam para os meninos para vir aqui a trabalhar, com casa, comida e salario. Uma vez que os meninos chegavam, trabalhavam e os donos pagavam o que eles queriam. Alguns reclamavam, diziam "não, o senhor vai me pagar tal quantidade... senão eu não trabalho mais e vou embora". Outros, não entanto, ficavam calados, eu não sei se era por vergonha o por medo que eles suportavam isso. Eu acho que é porque aqui passavam necessidades. Agora é um pouco mais tranquilo, os donos tentam cumprir e pagar.

Agora eu sei que os restaurantes peruanos, os conhecidos, estão respeitando um pouco mais as horas e os salários porque muitos peruanos começavam a reclamar e os donos para evitar problemas com a policia aqui começaram a cumprir. Teve muitos casos de denuncia e queijas de meninos cozinheiros de não receber salario e ser enganados. Por isso os donos para evitar pagar multas e ter uma má imagem do seu restaurante começavam a pagar aos trabalhadores. Também porque você sabe que os peruanos falam um pouco mais, o peruano não fica calado como os bolivianos. Esses sim não falam e aguentam de tudo. Eu sempre falei, quando não me pagaram, falei, quando me pagaram pouco, falei. Tanto assim que o dono me apelidou de "sindicalista". Eu sai desse ultimo trabalho porque já estava cansado de ver como o dono tratava os meus companheiros. Todos se queijavam comigo, mas quando eu falava e enfrentava ao dono todos ficavam calados e com um pé atrás, aí não tem o que fazer, né.

Mas em fim, eu não me acostumei a esse ritmo, e preferi sair desse sistema. Até porque no ultimo restaurante onde trabalhei que era de brasileiros, a comida era muito ruim, mas era a comida que era feita para os funcionários comer, porque a comida para os clientes era outra coisa, era boa. Além disso eu pensava - "ganho mais trabalhando por minha conta na feirinha que num restaurante". Vendendo na madrugada ganho mais em um dia do que trabalhando num restaurante dois dias. Eu trabalho para outros só quando me chamam, eu prefiro trabalhar para mim. Foi assim que deixei de trabalhar nos restaurantes e voltei a vender na feirinha, mas no começo me chocou porque andava com os olhos vermelhos porque dormia muito pouco. Pareciam os olhos do coiote quando não consegue agarrar o passarinho. E assim, eu comecei a ter muitos clientes 
que já me conheciam lá na feirinha e graças a deus esses clientes continuam aí, só que tem shoppings no Brás que não deixam você vender, mesmo assim tenho vários outros clientes na rua.

Meu dia a dia é assim: eu cozinho das onze da noite até as três da manhã. Arrumo todas as coisas, coloco as marmitas no carrinho e vou para o Brás. Eu levo garrafas de quinua, maca e também levo comida, 10 pratos de cada tipo de comida, levo lomo saltado, arroz chaufa (pratos típicos peruanos). Fico lá até as 7 ou 8 da manhã e depois vou para casa, descanso um pouco e saio para fazer compras, vou em vários mercados a comprar comida e na rua 25 também. Dai, eu volto para casa, deixo tudo arrumadinho para a noite e descanso mais um pouco. Mas depende, porque quando jogo futebol com os outros peruanos é difícil que eu descanse um pouco ou que complete todas minhas compras. E assim são todos meus dias, com exceção de sábados que não trabalho.

Assim é como eu trabalho, atualmente também faço pedidos de ceviche. Tem clientes que estão bebendo e me ligam ás duas da manhã e me perguntam que pratos tenho. E assim ofereço "tenho peixe frito, peixe ao molho, ceviche ou jalea". Assim me pedem que faça um combinado, então uma parte preparo em casa e outra levo para preparar lá mesmo, no boteco onde os clientes estão bebendo, geralmente quem me chama são peruanos. E assim eles pagam e eu vou, às vezes até me convidam um copo de cerveja, dois copos do que estiverem bebendo. Daí volto para casa, organizo as coisas, limpo, e no dia seguinte vou na feirinha.

Aqui a maioria dos peruanos trabalham assim, na rua. Os peruanos que chegam são para trabalhar no Brás vendendo roupas, muitos tem sua própria produção de costura, alguns se dedicam à costura também. Tem outros, geralmente jovens, que vem a trabalhar com comida, de cozinheiros em restaurantes. Tem muitos bolivianos também vendendo no Brás. Colombianos se dedicam, mas a emprestar dinheiro.

Eu acho que para quem é de fora a vida aqui é um pouco difícil. Aqui a gente tem que trabalhar muito para se manter. Lá todos meus amigos acham que aqui estou vivendo uma vida boa. Acham que aqui tudo é praia, musica, vida boa, mulheres. E não é assim, viver aqui não é um luxo, é muito suor, muito trabalho. Lá todos pensam que passo bem, inclusive a mãe da minha filha acha que estou curtindo, levando uma vida boa. Eles não sabem que a gente tem que amanhecer para trabalhar, ir no Brás a vender na madrugada, passar chuva, passar frio, passamos muitas coisas. Mesmo assim, eu gosto daqui, muito mais do que Peru. 
No Peru com isso de Gaston Acurio foi um “boom” trabalhar em cozinha. Todos os meninos que saiam das escolas queriam estudar cozinha e muitos deles nem tinham no sangue ser cozinheiro. Muitos deles não tinham ideia do que é machucar-se, queimar-se a mão, quebrar-se uma unha. Eles estudam cozinha e não sabem que depois vão ser só praticantes, então eles vão trabalhar numa cozinha como ajudantes e acham que vão sair como chefs. Estudam cozinha porque o amigo estuda cozinha, o primo, o vizinho, por isso alguns acabam desistindo. Virou uma moda, como que estudar cozinha era o máximo. Eu gosto muito da cozinha, mas sei como se sofre, sei o que é machucarse, o que é ser explorado.

\section{Sara}

“Eu já tinha experiência como camelo porque aprendi com minhas irmãs, por isso vender na rua depois não foi uma experiência difícil”

Quando cheguei na Venezuela eu fiquei trabalhando na oficina de costura da minha irmã. Daí fiquei entediada e não quis mais trabalhar aí, então ela me mandou a trabalhar no lugar dela, vendendo roupa. Com o tempo fiquei entediada também e conheci um colombiano que era dono de uma empresa de festas e comecei a trabalhar com ele, trabalhamos juntos por dois anos. A gente confundiu a confiança com o excesso e sempre discutíamos. Numa dessas discussões brigamos muito e eu parei de trabalhar com ele, sai daquele trabalho. Tínhamos problemas porque ele me dava muito trabalho, eu dormia muito pouco. Tinha que trabalhar todas as manhãs e depois nos eventos a noite. Ele pagava bem, mas o trabalho era cansativo demais... eu não tinha uma vida própria. Saí daquele trabalho, mas eu não tinha outra opção e comecei a trabalhar na rua... vendia roupa na rua por esses dois anos mais que fiquei por lá. $\mathrm{Na}$ verdade, eu já tinha experiência como camelo porque aprendi com minhas irmãs. Elas trabalhavam também vendendo na rua e eu via como elas faziam, as vezes também eu as acompanhava a vender, ajudava com a mercadoria delas. Então, por isso não foi uma experiência difícil.

Uma vez que deixei essa empresa e comecei a sair na rua para vender decidi que nunca mais trabalharia para ninguém... só para mim. Eu não gosto nem dos horários 
nem das ordens. Não gosto que me mandem. No meu próprio trabalho eu sou a chefe e eu sou a trabalhadora. Se eu vou me esforçar muito e me matar trabalhando tem que ser para mim...não para um chefe, você compreende?

Bem, depois eu vim para o Brasil, eu queria fazer dinheiro trabalhando na Copa do mundo. No começo quando eu cheguei me chocou muito. Foi muito difícil para mim trabalhar aqui. Eu estava acostumada a ganhar dinheiro todos os dias, a vender ou trabalhar e ter dinheiro fixo. Mas quando eu cheguei, não sabia o que fazer. Tinha casa, meu tio me ajudava com a comida, mas eu não tinha dinheiro nenhum, não tinha um real no bolso. Com meu primo, o que fizemos para começar a ter dinheiro foi algo que nunca tínhamos feito na nossa vida. Lembro que era época de carnaval e um senhor nos perguntou - "Vocês estão precisando de dinheiro, certo? Já cataram latinha de cerveja? só tem que pegar as latinhas na rua, as aplastar e pronto, vocês receberão uma grana por fazer só isso". Então a gente não tinha outra opção e estávamos precisando de dinheiro. Saímos um dia de carnaval e começamos a juntar um monte de latas, horas de horas juntando e aplastando, mas quando fomos levar todas as latas, o cara pesou tudo e nos deu só 40 reais. Eu falei - "nunca mais! Não vou sujar minhas mãos só por 40 reais". Como a gente não conhecia ninguém, não tínhamos vergonha, mas igual... a gente nunca tinha feito essas coisas.

Tempo depois fui na ponte São Bento e aí conheci um grupo de peruanos, todos jovens. Eles falavam sempre da 25 de março e uma vez de madrugada desci para ver o que tinha na 25. E foi assim como comecei. Um amigo me deu mercadoria para vender e foi assim como comecei a ir na rua a vender. Assim, sem querer, cheguei no Brás e comecei a vender aí na feirinha de madrugada... aí não quis mais voltar e acabei ficando, levo já 3 anos aqui. Teve vezes em que quis ir embora para Peru. E estou ainda assim... pensando, só que aqui o dinheiro se faz mais rápido, pelo menos para a gente que todos os dias temos dinheiro na mão. Eu no Peru teria que trabalhar muito para ganhar o que ganho aqui.

Economicamente o país está tentando se estabelecer mas o que acontece é que no Peru temos um atrasado nas leis trabalhistas ou não estão sendo respeitadas, como acontece com outros países. Na Venezuela, por exemplo, você trabalha num lugar por 6 meses, se você não estava contente com o trabalho, podia deixa-lo... igual você saia com um dinheiro por ter trabalhado esse tempo, você recebia benefícios. Na Venezuela você trabalha 8 horas, no Peru você tem que trabalhar até 12 horas e com um salario mínimo. Lá, 10 horas são o mínimo que você tem que trabalhar. Mas no Peru se você tiver 
dinheiro e investe em um negocio, você fica lá fazendo dinheiro, porque tem movimentação para o negocio, para o dinheiro. Mas como trabalhador não dá, como te falei, são muitas horas que você tem que trabalhar e sem benefícios, a situação é complicada. Na Venezuela, por exemplo, Chávez era maluco... mas os venezuelanos e os estrangeiros nacionalizados ou os residentes tinham tudo em regra. Se a empresa te demitia, você podia processa-los e obter um dinheiro por isso. Mas no Peru, a empresa tira tudo de você, até o ultimo e é você quem não recebe nada. Lá nada se respeita, eu acho que os empresários lá fazem tantos acordos com outras empresas, que acabam beneficiando aos donos e não ao trabalhador, esse é o maior problema.

Lá na feirinha tem pessoas de muitas nacionalidades vendendo na feirinha, tem venezuelanos, colombianos, bolivianos, brasileiros, paraguaios... tem de tudo. Todos eles vendem com exceção dos colombianos, eles emprestam dinheiro ou roubam. Para mim, trabalhar de madrugada me parece muito cansativo... mas o ser humano se acostuma a tudo nessa vida, sabe. Eu já me acostumei, mas sinto o trabalho muito cansativo, disso tenho certeza. Mas todos nós trabalhamos assim para juntar um capital e investir em outra coisa mais para frente. Eu já me acostumei e não tenho problema em isso. Não acho difícil trabalhar nem na madrugada nem na rua. Tem problemas sim, como sempre, mas se você não sabe afronta-los esta perdida. Na rua você trabalha até a hora que você quiser e ganha mais do que um salario mínimo, sempre.

Meu dia a dia é assim: eu acordo 1 hora da manhã, media hora depois começo a tomar banho e as 2 da manhã eu já estou lá na feirinha. Na feirinha eu trabalho até o horário que eu quiser, seu eu quiser fico até as 7 da manhã ou se quiser volto em casa ao meio dia...isso depende. Daí eu volto em casa, almoço, arrumo meu quarto, arruma minha casa ou lavo a roupa, e depois descanso, se eu tiver que sair eu saio, se não fíco em casa.

\subsubsection{Análise das entrevistas}

A través do depoimento dos próprios entrevistados, dados a partir das entrevistas com imigrantes em lugares aleatórios, dados levantados a traves do consulado e organizações que trabalham com assistência aos imigrantes e pesquisa bibliográfica sobre o tema, é que se conhece que a maioria de peruanos imigrantes na cidade de São Paulo, se dedica ao comercio ambulante nos principais centros de mercados populares, 
sendo uma delas a Feirinha da Madrugada do Brás e da Rua 25 de março, seja vendendo na calçada ou como proprietários ou ajudantes nos boxes nessa regiões.

Como vimos nas entrevistas, os imigrantes na sua chegada ao Brasil, encontram no comercio ambulante uma possibilidade de sustentar seus gastos e conseguir sobreviver em São Paulo, cidade que como todos afirmam uma das mais caras da região e com o custo de vida mais elevados expressado na alta taxa de aluguel e formas de moradia, assim como um elevado preço dos alimentos e demais serviços. Além do trabalho como vendedores ambulantes, outra atividade comum a ser realizada por peruanos é de cozinheiros e ajudantes nas cozinhas nos restaurantes de comidas peruanas na cidade.

É importante ressaltar que ademais de trabalhar na feirinha, a maioria de imigrantes realiza outro trabalho, seja vendendo a mercadoria em outros momentos do dia e em outros lugares, trabalhar nos boxes de roupa e outros negócios de algum parente. Outros se dedicam a produzir sua própria mercadoria como vimos na narrativa de Jandy, atividade que depende também de outros imigrantes, principalmente bolivianos, para determinados processos de produção como corte, costura e estampado das peças.

O percurso que levou os imigrantes a trabalhar como ambulantes na Feirinha da Madrugada foi muito diverso. É importante assinalar que os imigrantes já possuem uma rede ainda antes de chegar no Brasil. Essa rede esta conformada em alguns dos casos por familiares e amigos, cujo dono propõe a tios, sobrinhos e irmãos no país de origem a possibilidade de vir ao Brasil para "ajudar" no negocio, seja na costura ou na venda, com a oportunidade de ganhar um pequeno salario em troca de casa e comida nos primeiros meses. Outros casos a rede a traves da qual os peruanos chegam, são redes de captação de mão de obra, onde os trabalhadores conhecem a pessoa que os contata só na hora da chegada, como acontece com os jovens cozinheiros.

Trabalhar na Feirinha da Madrugada implica ajustar a dinâmica do dia a dia ao trabalho em horário de noite e madrugada. Isto é acordar diariamente às duas ou três da manha e, dependendo das vendas ficar na feirinha até as 10 da manha ou mais. O trabalho requer também de organização e planejamento, isto é, deixar pronto a mercadoria na noite antes, já empacotada acima dos carrinhos, instrumento que usam para transportar a carga já que geralmente, eles vão andando até o lugar da feira desde seu lugar de moradia, situadas nas regiões da Luz, Brás, Republica. 
Dentro da dinâmica da Feirinha existe muito conflito e disputa pelo espaço destinado ás vendas. Esses conflitos se dão principalmente entre os próprios vendedores da calçada, sendo as mais comuns as brigas entre camelos brasileiros e camelos imigrantes. O conflito se da também entre vendedores e alguns grupos organizados que realizam o cobro de aluguel ou venda de pequenos espaços administrados e delimitados por eles com um giz. Existe também a presença grupos de segurança conformada, segundo as narrativas, por policiais em retiro, os quais realizam um cobro semanal de 50 reais principalmente aos camelos estrangeiros, para assegurar-lhes a proteção contra as brigas com os outros vendedores.

Por outro lado, existem certas especialidades cumpridas por determinados grupos migratório cuja função é ao mesmo tempo fortalecer ao sistema capitalista. Como é o caso dos imigrantes colombianos destinado a emprestar dinheiro a outros imigrantes. esse grupo migratório é reconhecidos por migrantes de outras nacionalidades como o grupo que empresta dinheiro e trabalha unicamente disso. Devido a que a maioria de imigrantes comerciantes não tem acesso ao credito bancário no momento de querer abrir um negocio, montar uma pequena banca ou box para vender roupa, ou simplesmente comprar sua primeira mercadoria para começar a vender na rua, acodem a pessoas especificas, geralmente indicados por outro comerciantes, encarregadas de emprestar dinheiro, nesses caso são jovens imigrantes colombianos que geralmente trabalham para um maiorista, dono do dinheiro, o que se conheceria como agiota, no caso do Brasil.

Para os imigrantes, o trabalho na Feirinha de Madrugada é uma atividade muito desgastante e cansativa, ressaltando também o risco que atravessam devido às perseguições policiais a as consequências de ser pegue pela policia, isto é, a possibilidade de perder sua mercadoria e ser prendidos em caso de mostrar resistência. Cabe ressaltar que a maioria dos imigrantes camelos, devido a sua situação irregular no pais em alguns casos, temem ser prendidos pela policia e mandados embora de volta a seus países. O trabalho como camelo é uma atividade de alta precarização, vulnerabilidade e instabilidade que, embora a sensação de liberdade e independência que os imigrantes acreditam ter, é também motivo de grande incerteza já que acabam tendo dinâmicas muito cansativas de trabalhado devido a pressão que eles mesmos se colocam por conseguir a meta diária de ganancia. 
CAPITULO 4

4. O DIREITO À MORADIA EM CONTEXTO MIGRATÓRIO 


\subsection{Imigração e direito à moradia}

Com a crescente chegada de imigrantes e refugiados para São Paulo, cresce também a demanda por moradia. A necessidade de habitação é uma das primeiras urgências que os imigrantes devem resolver na sua chegada em São Paulo, afrontando ao mesmo tempo um grave problema social que atinge a milhares de brasileiros e brasileiras: o acesso a moradia.

São incontáveis as regiões no mundo que vem sendo cenários de diversas formas de violação de direitos humanos sendo a moradia um dos direitos básicos mais transgredidos. Segundo Rolnik (2015) o mundo em questões relacionadas à moradia vem afrontando os impactos de uma "implementação ideológica e pratica hegemônica de um modelo de politica publica de habitação baseada na promoção do mercado e do credito habitacional". Assim, a partir da logica de mercado, a questão de moradia passou de ser um direito a um ativo financeiro.

Em vários países do mundo foi implementado o que Rolnik chama de "programas de subsidio à demanda" (op. cit. p, 111). Esses programas do governo consistiam basicamente na "ajuda" financeira vinda do recurso publico para subsidiar a moradia da população de baixa renda. Os aportes podiam ser pagamentos na entrada da compra de um imóvel ou nas prestações mensais, isenções fiscais ou programas relacionados à poupança. Esse ultimo consistia em bônus outorgados aqueles que conseguissem poupar, incentivando assim à poupança e assegurar que as famílias entrem no sistema financeiro. Todos esses programas gerariam grande movimentação de recursos públicos beneficiando exclusivamente à população de classe media e todos aqueles com capacidade de poupar e deixando do lado a ajuda aos mais pobres que dependiam desse recurso para acessar à moradia. É importante ressaltar que no caso do Brasil esses subsídios foram as únicas formas de politica habitacional que o pais contava entre os anos 1960 e 1970.

Traz o golpe militar do Chile no ano 1973, o país serviu como laboratório e referencia de drásticas medidas neoliberais nos setores de saúde, educação, habitação e aposentadoria, as quais que logo se propagariam ao resto da América Latina. O modelo chileno de politica habitacional consistiu basicamente na

[...] mudança de responsabilidade pela provisão de moradia do governo para o setor privado; a oferta de uma doação de capital única para a compra da moradia e, ao mesmo tempo, o corte de todos os 
subsídios indiretos; e mecanismos de qualificação de beneficiários a partir de um sistema transparente de pontuação, baseado na renda familiar e na capacidade de poupar (op. cit. p, 114).

Assim o financiamento e a construção de moradia foram transferidos para o setor privado o qual levou a cabo processos de estratificação da demanda baseada na renda das famílias. Assim o financiamento dava-se basicamente tanto a partir da poupança das famílias como a sistemas hipotecários. Com o mercado privado como único responsável da administração da oferta habitacional iniciasse a construção massiva de habitações para a população de menos recursos. As empresas construtoras com respaldo no Estado, modificaram os padrões das novas "casas para pobres" diminuindo ao mínimo os custos de construção a traves do tamanho das casas construídas e os lotes. Levaram-se também reformas no mercado das terras urbanizando aceleradamente as cidades levando assim esses novos bairros populares até as periferias. Com ajuda das forças armadas, a população que habitava nas antigas ocupações de terra formadas no governo anterior, foi forçada a se deslocar para os novos conjuntos habitacionais nas periferias e obrigados a habitar casas de tamanhos demasiado reduzidos.

Programas de subsidio a moradia foram e continuam sendo implementados em vários países da América latina como é o caso do México e do Brasil onde milhares de famílias de baixa renda passaram a ser proprietárias de pequenas casas e apartamentos de baixo padrão e qualidade. Por outro lado, a segregação social e espacial constitui um problema muito grave nesses cenários ao reunir os assentamentos habitacionais em guetos situados sempre nas periferias e zonas marginais da cidade, que além da violência e insegurança, presentam limites no acesso a educação, trabalho, saúde e serviços urbanos.

Outro fenômeno desencadeado a partir da lógica da financeirização da moradia é a crise global da segurança de posse, onde milhões de pessoas são deslocadas forçosamente e obrigadas a deixar suas vivendas e bairros devido a execução de grandes projetos, problemas hipotecários, conflitos armados, retenção das terras por parte dos grandes capitalistas, expansão do agronegócio e empresas de mineração. Nas palavras de Rolnik, 
território habitado constitui um dos mecanismos poderosos da maquina da exclusão territorial e de despossessão em marcha no contexto de grandes projetos, sejam eles de expansão da infraestrutura e desenvolvimento urbano, sejam de reconstrução pós-desastre (op. cit. p, 13).

Nos países subdesenvolvidos e emergentes o espaço rural e urbano, constituem um recurso de muita disputa, as medidas implementadas pelos estados para a reconstrução pós desastre e a implementação de obras de grande magnitude se vem, na maioria dos casos, diretamente determinadas pelas relações de posse, bloqueando assim os direitos básicos de moradia e vivenda digna de grande parte da população, geralmente a população de mais baixos recursos desprovidos de legitimidades.

É sabido que o espaço geográfico e social, no qual habitam as populações mais pobres, camponeses, indígenas, ribeirinhos é, ao mesmo tempo, zona de alto risco em casos de desastres naturais e, devido à sua condição socioeconômica, é mais difícil a recuperação pós-desastre. Por sua vez, o termo "desastre natural" esconde um processo social que determina e define as condições do lugar de alto risco (ROLNIK, 2015). Assim, a maioria das vezes os impactos de terremotos, inundações, ou furacões estão diretamente relacionadas com as politicas de habitação, propriedade da terra e planejamento urbano na cidade. Por mais incrível que pareça as medidas pós-desastre implementadas pelo estado continuam excluindo às comunidades mais afetadas destinando a maior parte dos recursos para a reconstrução da propriedade privada, no lugar no auxiliar em termos de moradia à comunidade afetada, originando assim um incremento de pessoas e famílias sem teto. Já em casos onde as catástrofes acontecem em territórios de disputas pela tenência da terra, habitada geralmente por trabalhadores pobres, camponeses e indígenas, os governos implementam medidas de reconstrução habitacional auxiliando primordialmente a problemática do teto, deixando assim de lado as demandas da população em matéria de propriedade da terra.

Os casos de países de sediaram grandes eventos como foram os casos da Copa do Mundo e as Olimpíadas, levaram-se a cabo drásticas medidas de despejo, perseguição, deslocamento forçados e demolições das casas de moradores que ocupam áreas com grande demanda para a construção de complexo esportivos, vias publicas e alojamentos. Cabe ressaltar a prioridade por parte do governo e demais entidades de eliminar qualquer sinal de pobreza e miséria, que pudera afetar a aparência da cidade linda e desenvolvida ante o olhar dos visitantes. 
Poder-se-ia continuar narrando outras maneiras de privação de este direito no mundo que corroboram o fato da moradia, a partir da logica capitalista, é valorada mais pelo seu valor de troca do que de uso, favorecendo unicamente aos grupos econômicos dominantes, como especuladores de terra, grandes construtoras e famílias de classe media, as quais pelo seu poder aquisitivo podem aceder ao mercado habitacional.

\subsection{O problema da moradia no Brasil}

O Brasil está entre os países com maior déficit habitacional do mundo, seguido da África do Sul e da Índia (BOULOS, 2015). Esse déficit habitacional esta determinado tanto pelo numero de famílias que não tem casa, quanto pelas famílias que vivem em situação extremadamente inapropriada ou precária. Segundo dados estatísticos, no Brasil quase 22 milhões de pessoas, isto é, mais de $10 \%$ da população, não tem casa ou moram de favor em pequenas habitações improvisadas em casas de familiares ou amigos. Por outro lado, perto de 48 milhões de pessoas não tem condições mínimas de moradia digna, isto é, falta de agua, luz, esgoto, coleta de lixo e outros serviços básicos e infraestrutura. Somada a este problema esta a superlotação de residências, na qual pequenos cômodos albergam um numero excessivo de pessoas.

O problema habitacional no Brasil tem como característica a existência de muitos imóveis desocupados, quase o numero de pessoas sem teto. São aproximadamente sete milhões de famílias sem casa no Brasil, sendo que existem mais de seis milhões de imóveis vazios e em condições de ser ocupados imediatamente. Esses imóveis vazios pertencem a um pequeno grupo de capitalistas e são usados geralmente para especulação imobiliária. Assim, o direito a posse de uns poucos se superpõe ao direito ao direito a moradia do resto da população, afetando diretamente às famílias e trabalhadores mais pobres.

$\mathrm{Na}$ historia do país, levaram-se a cabo dois programas habitacionais. O primeiro foi o chamado Banco Nacional de Habitação levado a cabo na época da ditadura militar e seguiu uma logica bancaria de financiamento da moradia no qual o imóvel era destinado principalmente para pessoas com capacidade de adquirir uma casa, isto é, de três salários mínimos para acima, deixando do lado assim aos trabalhadores mais pobres e com maior necessidade de moradia. O segundo programa, Minha Casa Minha Vida, foi lançado no governo do presidente Lula meses depois da grande crise do mercado 
imobiliário dos Estados Unidos e que afetou à economia do resto do mundo. Com as empresas brasileiras em falência, o governo federal implementou medidas para resolver a crise das grandes empreiteiras imobiliárias, deixando assim nas mãos dessas empresas a construção de milhares de moradias populares para, ao mesmo tempo resolver o problema habitacional. Boulos afirma:

as empreiteiras receberam o presente de $\mathrm{R} \$ 34$ bilhões para aliviar sua crise. O sistema é simples: o governo dá o dinheiro, a empreiteira constrói e o governo apresenta os compradores. Ou seja, não há nenhum risco para o capitalista nem necessidade de gastos com a venda. E tudo com dinheiro publico. (op. cit. p.40).

Por outro lado, devido a que foram os empresários os encarregados de planejar e construir as moradias, é que seguiram a logica de mais lucro e menos gasto. em consequência, os conjuntos habitacionais foram construídos em regiões periféricas à cidade, em terrenos de baixo custo para as empreiteiras. Além disso, são construções com pouca infraestrutura, e no caso dos proprietários com menos de três salários mínimos, o tamanho das casas não passa dos quarenta metros quadrados. Com tudo, os programas não conseguiram solucionar o problema de moradia no Brasil já que priorizou-se a conciliação do setor privado com o governo, no lugar de responder ao déficit habitacional do pais e oferecer moradia digna as famílias mais pobres. São Paulo é o estado brasileiro que concentra a maior quantidade de essas moradias superpovoadas. A maioria dessas pessoas sem teto ou que vivem em condições muito precárias são trabalhadores pobres moradores das periferias urbanas, muitos dos quais trabalham em situação de irregularidade e sem um mínimo de direitos assegurados.

Por outro lado, na Cidade do Capital, acontecem as medidas segregacionistas mais escancaradas e apoiadas pelos interesses públicos e pelo estado, como é no caso de São Paulo e do Rio de Janeiro, cidades caracterizadas pela extrema desigualdade. Para os rios, não bastou que os pobres se aglutinassem em lugares exclusivos para eles, como são nas favelas; se não que insistiram em criar mecanismos para manter a população "marginal" longe dos seus olhos e sem incomodar. É assim que as empresas privadas juntos aos governos de estado implementam medidas para segregar ainda mais a população pobre do resto da cidade, como são a construção de muros em torno das favelas no Rio de Janeiro, a construção de condomínios fechados com cerca elétricas e seguranças armados, as "rampas antimendigo" para afastar aos moradores de rua, implementadas pelo prefeito Jose Serra na cidade de São Paulo, assim como as "lixeiras 
anticatador" dos condomínios de luxo para evitar a presença dos trabalhadores de reciclagem (op. cit. p.64). Na loja capitalista, segregar implica lucro devido à valorização dos espaços, transformados já em mercadoria.

\subsection{A habitação dos imigrantes}

Já que se entende o trabalho e a procura do trabalho como uma condição que justificaria a presencia do imigrante em determinado lugar, é imprescindível diferenciar também as condições entre um trabalhador nativo e um trabalhador imigrante. Tais diferencias recaem primeiramente no acesso a moradia. Os imigrantes, na sua chegada ao Brasil, reparam que o país alberga uma serie de problemas sociais de diversas magnitudes, sendo uma delas a falta de moradia. É certo que uma grande parcela da população em São Paulo afronta a falta de moradia, mas existem limitações especificas que os imigrantes têm que encarar pela sua condição de imigrantes, as quais dificultam o acesso a uma habitação e a condições mínimas de moradia digna.

Já que se entende o trabalho e a procura de trabalho como uma condição que justificaria a presença dos imigrantes em determinado lugar, é relevante diferenciar também as condições entre um trabalhador nativo -alguém que se entende já nasce dentro de um lar estabelecido- e um trabalhador imigrante. Moradia e trabalho, no caso dos imigrantes, são duas dimensões do vivido totalmente interligadas e que guardam uma relação de mutua dependência (SAYAD, 1998).

As condições de moradia estão determinadas pelo caráter provisório que define tanto a estadia dos moradores imigrantes no lugar de imigração, quanto pelo uso provisório que estes imigrantes lhe outorgam a esses espaços, basicamente para responder suas necessidades de moradia provisória. Seguindo as representações que se tem comumente sobre os imigrantes, o imaginário de moradia dessa população é a de uma habitação precária e simples, de acordo a sua condição econômica, uma habitação de acordo a um trabalhador que se esforça por poupar e economizar na medida do possível, trabalhando muito e gastando muito pouco, " uma habitação pobre e de emergência e uma habitação pobre para um ocupante conhecido como pobre e em situação de emergência“(op. cit. p. 75).

Pensar nas questões de vivenda e acesso a moradia no caso dos imigrantes requer de um olhar sobre vários aspectos que condicionam e limitam o acesso dessa 
população a uma vivenda digna. Condições análogas ao trabalho escravo, uma renda por debaixo do salario mínimo ou formas de trabalho sem direitos nem benefícios laborais são realidades às quais os imigrantes se submetem por falta de oportunidades na sociedade de "acolhida". Além disso, a maioria deles tem o dever e compromisso de enviar remessas a seus familiares nos seus países de origem, reduzindo ainda mais a renda da qual depende o seu sustento na cidade, uma das cidades com o custo de vida mais alto na América Latina. Outro fator que limitaria o acesso a moradia da população imigrante são as atitudes e praticas discriminatórias por parte dos proprietários e agentes imobiliários no momento de alugar uma casa ou apartamento, seja pela falta de documentos ou pelo fato de serem imigrantes.

\subsection{Narrativas dos e das imigrantes - A questão da moradia}

\section{Jandy}

Eu tenho parentes que já estavam morando aqui em São Paulo quando eu cheguei, foi um sobrinho meu que me recebeu. Também eu tinha um irmão que estava em um apartamento que dividia com varias outras pessoas, cheguei a um prédio desses, como lhe chamam aqui? Ocupações, isso. Eu fiquei nessas ocupações porque eu cheguei a São Paulo sem saber direto o que fazer, eu tive que ver e procurar em que iria trabalhar. Então precisava de uma estabilidade para poder pagar um quarto e aqui o aluguel é muito caro, ao contrario nos prédios onde eu pagava 200 ou 150 reais.

Bem, eu já sabia que chegaria num desses lugares porque na Venezuela também é assim, mas lá é diferente, são invasões. Lá invadem prédios, casas e são os malandros que se apropriam, são os bandidos que se fazem donos. Aqui é diferente, é mais organizado, são organizações que ocupam e moram famílias inteiras. Eu tenho passado por vários também que não são tão bons, mas todos cobram muito barato para você ficar lá. Por exemplo, no primeiro prédio onde fiquei eles me cobravam 150 reais por mês. Eram uns prédios no centro da cidade, eu acho que eram antigos escritórios, hotéis. $\mathrm{O}$ movimento dividia os quartos com madeiras ou cortinas para fazer mais espaços e alugar.

E assim, eu cheguei. Como eu sou uma pessoa que se adapta a todo lugar porque eu tenho viajado muito e tenho passado e ficado em muitos lugares também. Até tenho 
dormido em rede nessas balsas na Amazônia onde ficava tantos dias. Em fim... eu fiquei num total de três prédios. A ver... o primeiro foi quando eu cheguei aqui, onde morei com meus sobrinhos até que meu sobrinho me diz um dia - "tia, a gente vai ter que sair daqui, mês que vem a gente tem que ir embora porque a organização vai sair"-. E assim a gente se mudou em outro prédio, um da esquina mesma na Rua Rio Branco. Nossa! Esse prédio sim era terrível, tinha ratos. As pessoas fumavam muito nessa invasão, tinha pessoas muito sujas que não limpavam nada, os banheiros andavam sempre sujos. Então, eu não aguentei e saí daí, fui para outra ocupação, um prédio em melhores condições. Daí num prédio na frente do Mercadão, mas nos mandaram embora aos cinco meses, então fui em outro prédio na Praça da Sé, ali na frente da igreja tinha um prédio, mas não passou nem um mês e nos mandaram embora também. A gente tinha que deixar o lugar quando o movimento perdia o processo contra os donos dos prédios. O movimento mesmo nos avisa um pouco antes para nos preparar. Nesse prédio do centro, por exemplo, os donos eram uns sacerdotes que começaram um processo contra nós, eles têm advogados e sempre ganham. Então a gente tem que ir embora. Nossa... esse prédio da Sé era muito lindo, muito limpinho, os banheiros, tudo. Tinha um chão muito lindo, tudo bem cuidadinho, mais nem modo, a gente teve que ir embora. Depois disso fui num prédio da frente, era da mesma organização também. A gente ficou nesse prédio cinco meses, mas também tivemos que sair. Por sorte nos levaram num outro prédio que era do mesmo movimento e assim nos acomodaram aí.

Lembro que nesse ultimo prédio ficaram muitas vagas de pessoas que não pagavam. Os encarregados veiam quem não pagava e os mandavam embora para dar espaço a quem pagava. Eles levam um controle da entrada e saída, você recebe uma carteirinha, sem ela não é possível entrar no prédio. Você aluga um quarto e aí podem morar vinte pessoas se você quiser, esse não é problema do movimento. Eles pedem uma certa quantidade de dinheiro no ingresso e depois um pago mensal. Às vezes pedem mais uma quantidade adicional quando o elevador quebra o quando tem que concertar algumas coisas. Com 150 reais de cada um, eu suponho que já dava para concertar o ano todo.

Nesses prédios moram mais de mil pessoas, moram muitas famílias! Eu por exemplo, morava no andar 11, era o ultimo. Nesse andar lembro que tinham bastantes famílias, muita gente. $\mathrm{O}$ andar onde eu morava era tranquilo, era muito limpo. Eu acho que esse prédio era um hotel. Tinha vários quartos no andar e um corredor bem amplo. 
Em cada entrada tinha como quatro quartos e compartilhávamos um banheiro cada duas habitações. Moravam muitas pessoas, tinham brasileiros, peruanos, dominicanos. Eu não fazia muita amizade, ficava mais na minha, os vizinhos veiam que eu costurava e as vezes me lavavam suas roupas para eu concertar. Mas normalmente, cada quem fazia suas coisas e assim eu não tinha que ver com ninguém. Eu saia, subia, voltava no meu quarto. Eu trabalhava com a porta aberta e era tranquilo porque aí só entrava quem morava aí, mais ninguém. Mas eu sei que em outros andares era uma bagunça, muito sujo, as pessoas dormiam o dia todo, eram pessoas de mau viver que vendiam drogas na rua. Tinha também muitos ladroes morando aí, inclusive bandidos colombianos, tinha também prostitutas. Em fim, pessoas de mau viver que dormem de dia e a noite saem para rua o ficam no prédio fazendo barulho, não deixam os outros dormir porque ficam cozinhando, escutando musica na madrugada. No andar 10, onde meu amigo morava era assim, a noite era como o dia. As pessoas faziam tudo de madrugada, faziam muita bagunça e de dia era silencio total. Mas também tinham pessoas que trabalhavam muito, peruanos ou bolivianos que tinham suas oficinas de costura aí nos seus próprios quartos. outros que trabalhavam vendendo comida na rua ou repartindo marmitas. Inclusive eu mandava a costurar com uma senhora boliviana e seu esposo peruano que tinham sua oficina em outro andar. Assim eu andava assim, subia e descia pelo elevador. Tinha também muito haitianos, africanos, árabes, de todos os países tinha esse prédio. Esse movimento é dos mais organizados que eu já conheci, eles tinham tudo organizado. Por exemplo, quando você não pagava eles deixavam na tua porta um papel, uma citação para falar com você. Se você não ia eles quebravam tua porta e esse era um aviso para te advertir que se não pagava você teria que ir embora.

Nos prédios onde eu fiquei tinham muitas pessoas de fora. Nas primeiras ocupações tenho visto muitos peruanos. Bolivianos tenho visto muito pouco, eles quase não moram em ocupações. Nos últimos prédios onde eu estive aí sim tem de todos os países, todos. Por exemplo, tem um prédio descendo do Teatro Municipal, esse pertence à prefeitura, e estava cheio de pessoas de muitos países, africanos, colombianos, árabes, peruanos. Era tranquilo morar com pessoas de outros lugares, mas aconteceu que uma vez eu tive um problema que envolveu a minha irmã... um problema muito serio que me deixou muito mal. Aconteceu que a gente dividia com um haitiano uma habitação dentro de um prédio. Minha irmã e eu conhecemos esse senhor no segundo prédio onde a gente ficou. Deu a casualidade que eu estava pensando ir embora desse prédio porque os nossos vizinhos eram terríveis, não deixavam dormir. O haitiano morava também 
nesse andar e um dia ele estava limpando seu quarto e fiquei sabendo que minha irmã tinha deixado um colchão para ele usar. Essa foi a primeira vez que eu falei com ele.

Aconteceu que um dia eu estava procurando um outro prédio para ir embora e justo esse dia escuto alguém fazendo um barulho no corredor, era ele arrastrando sua geladeira porque estava mudando todas suas coisas para outro prédio. Eu sai do meu quarto e diz para ele - “oi! Você esta indo embora? para onde você vai?" - E ele me diz "eu vou embora para outro prédio. Achei um prédio muito melhor do que este, tem agua e luz o dia tudo". Eu achei ótimo porque no prédio onde estava só tinha luz durante a noite, então de manhã eu não podia trabalhar. Assim, fiquei interessada e pedi para ele me separar uma habitação naquele outro prédio. Ele falou - "Perfeito! Eu vou pegar então um quarto para nós e no sábado agente já pode ir para lá”. Bem, chegou sábado e a gente foi para aquela ocupação com todas nossas coisas, o problema foi que apareceu um senhor gritando - "não! Não dá para vocês morar num quarto só! É muita gente, vocês não podem!". Achei um absurdo porque o quarto onde íamos ficar era grande, e tranquilamente podíamos entrar três pessoas, mas em fim. A gente não podia fazer muito porque estávamos com todas nossas coisas e já não tínhamos outra opção.

Pedimos para aquele rapaz se podíamos ficar os três num quarto só por quinze dias e já depois iriamos num outro quarto. Foi assim que moramos os três juntos por esse tempo num quarto só e foi muito tranquilo, na real, ele trabalhava o dia tudo como eletricista numa empresa e voltava só para dormir. Esses dias a gente cozinhava, conversava, ele trazia comidinhas para gente, a gente cozinhava para ele, foi tudo muito tranquilo. E na real eu nunca tinha tratado com um negro, mas pensei- "este senhor deve ser bom, olha só como ajudou a gente, nos trouxe para cá e nos ajuda todos os dias”.

Ele inclusive lavava nossas roupas, a gente voltava do trabalho na manhã e ele já estava com nossas roupas estendidas no varal. Então éramos como uma família, estivemos juntos até o ultimo prédio. Lembro que uma vez ele ficou doente, passou 18 dias soluçando e não parava com nada. No hospital lhe receitaram medicamentos e mesmo assim, nada! Fui eu quem o curou... curei ele com limão. Um dia ele voltou do trabalho se tremendo todo, não podia nem falar. Aí, eu preparei um chá bem quentinho com muito limão, exprimi mais de dez limões! Eu o agasalhei e botei para dormir. No dia seguinte ele acordou muito melhor e não soluçou mais. Ele não tinha conseguido dormir por 18 dias porque não parava de soluçar e também tinha uma tose muito forte.

Em fim o tempo passou e nos mudamos os três para outro prédio. Nesse prédio, ele ocupava um quarto no andar onze e eu e minha irmã ocupávamos um quarto no 
segundo andar. Ele descia para nossa habitação para comer e almoçar com a gente, depois ele voltava no seu quarto para dormir. Ele tinha uma irmã na Suíça que ajudava ele enviando dinheiro desde lá. Ele diz que, na real, estava aqui para tramitar seus documentos para ir à Suíça, ele dizia- "se eu quiser não trabalho porque minha irmã me envia dinheiro". Mas eu fiquei muito chateada com ele quando a gente se mudou para outro prédio. Minha irmã chegou um dia e diz- "tenho achado um prédio melhor! Com quartos maiores! Assim ele pode ficar num lado da habitação e a gente do outro lado! Eu pensei, perfeito! Vamos lá! Entre todos tínhamos que pagar 520 reais pelo espaço e eu pensei- "tá ótimo, assim a gente paga uma parte e ele a outra". Minha irmã e eu fizemos tudo o possível para arrumar esse dinheiro e ele não tinha dinheiro para pagar!

A gente teve que pagar tudo, e a parte dele também! Eu pensei que mínimo ele iria pagar os 80 reais do frete que estava levando todas nossas coisas... e nada! Nem para isso ele tinha! Eu fiquei muito brava e comecei a discutir com minha irmã - "ou seja que se não fosse por a gente ele iria parar na rua?! Que coisa! Ele é um homem que trabalha e tudo, é a gente que vai pagar por ele?! Não está bem!” - Enfim... a coisa é que ele veio conosco e ficou morando no mesmo quarto. Quando a gente teve que sair desse prédio eu falei para ela- "ele não vai mais com a gente, se ele quiser que alugue sozinho um quarto". E para alugar esse quarto era com titular, e minha irmã foi a titular porque eu tinha dado o dinheiro para ela pagar e fazer todos os tramites, então ela deu seus dados para alugar... assim que nem eu nem ele podíamos pegar por nossa conta uma habitação, tinha que ser só ela. Assim que eu falei para ela- "Não, ele não vai morar mais com a gente, eu preciso de um espaço maior para ter minhas maquinas e trabalhar. A gente não pode mais viver apertados e sem espaço" - Nossa... ela começou a brigar comigo! - "ele também tem direito de vir!”- Ou seja ela defendeu ele e começou a brigar comigo. Eu falei para ela- "ah tá bom... se é assim... vá embora com ele então, vai morar com ele que eu vou procurar um outro canto para ficar". Em fim... a gente foi morar juntos de novo, ela não se importou com o que eu lhe disse e colocou ele no quarto com a gente... de novo! Esse dia a gente brigou muito e mesmo assim ela foi até o aeroporto a pegar o filho dele, do haitiano. No final minha irmã acabou ficando com esse negro... nossa... ela acabou namorando com esse negro, ela tendo seus filhos e seu esposo no Peru. Os dois filhos dela inclusive já estavam morando aqui, como ela fez uma coisa dessas? eu não sabia de nada! Uma cunhada tinha visto eles andando de mão dada pelo centro e nem ela nem ele me contaram nada! E bem folgado era ele! Eu já tinha percebido umas coisas estranhas... que minha irmã fazia a comida dele, que lavava e 
passava ferro na roupa dele... É que minha irmã sempre foi assim com tudo mundo, ela sempre sentia lastima de todos, tentava ajudar todo mundo... mas nunca imaginei uma coisa dessas! Eu encontrei um dia com meu sobrinho, eu continuava muito chateada com tudo isso do haitiano, e ele me diz- "não será que eles dois se gostam e você não sabe?” - Eu fiquei surpresa e respondi- “não! de jeito nenhum!”-. Para mim isso era algo impossível! Aí ele me diz- "é que tenho visto uma mensagem no telefone dela".

Nossa... fiquei muito brava. Esse mesmo dia eu ia fazer um escândalo, mas quando voltei em casa estavam ele, o filho dele que acabava de chegar do Haiti, minha irmã, minha sobrinha e outra amiga... já não dava para dizer nada, assim que entrei voando para não ver ninguém porque estava a ponto de estourar. Passaram uns dias e seu filho estava em casa com a gente, eu falei para o menino - "Desculpa por estar assim com você estes dias, por não receber você melhor, eu não sou uma pessoa ruim... a verdade é que estou muito brava com teu pai, eu não falo mais com ele por ter ficado com minha irmã". Ele ficou surpreso, justo ele estava comendo e jogou o prato na mesa e gritou: “como! Como é possível! Não acredito... meu pai?!”. E diz para ele - “sim! teu pai! Eu o recebi achando que era um bom cristão, uma pessoa boa que acredita em Deus e olha com o que aparece. Minha irmã é uma mulher casada e tem filhos e tudo.

Teu pai também, ele tem uma mulher lá no teu país, mas ele esta acostumado com isso, tá acostumado a destruir famílias porque desde o Equador que vem fazendo isso, destruindo famílias. Isso eu não vou permitir, assim que estou esperando você sair para mandar embora teu pai embora daqui, ele não pode mais ficar aqui e fala para ele que tem que ir embora”. Isso deu uma grande confusão porque o haitiano ficou muito bravo comigo e falou para minha irmã que eu era uma má pessoa, que fiz ele passar vergonha com seu filho. Em fim, eles continuaram juntos, minha sobrinha me contou que ela ia no quarto dele a cozinhar- lhe. Ela enlouqueceu! Assim que eu fiquei sabendo aquele episodio perguntei para ela- "quando ele vai embora?". Ela ficava brava comigo e dizia - "não sei! Quando seu filho vá embora também. E outra coisa, eu também vou embora, vou embora para o Peru!". E eu falei para ela - “eu já sei que vocês dois estão juntos. Você é uma má mulher, você não cuida da família, como você pode ficar com um aproveitador? tudo este tempo ele não deu nada e você só anda cozinhando e fazendo coisas para ele... o que é isso?! Todos aqui trabalhando e por isso temos para comer e para viver. Ele recebe ajuda de tudo lado e mesmo assim não recebemos nenhuma ajuda dele. Eu não quero ver mais você atendendo ele, lavando sua roupa, nem andando com ele pela rua". Ela ficou calada e não respondeu nada. Assim que passou o 
tempo e meu cunhado, lá no Peru, ficou sabendo, meus sobrinhos e tudo mundo. Minha irmã voltou para lá, ela esta no Peru agora, mas fiquei sabendo que ainda fala com aquele haitiano, mas em fim...eu agora estou mais tranquila. Para mim foi muito difícil passar por isso, não consigo aguentar quando minhas amigas ou parentes fazem isso de sacanear ao marido. E pior minha irmã! Ela é uma mulher já madura, com filhos, esposo... o que esse negro terá feito para ela ficar louca daquele jeito? eu acho que ele fez um feitiço, desses que fazem lá na terra dele.

Em fim, desse ultimo prédio iam mandar tudo mundo embora, depois nos disseram que podíamos ficar mais um tempo. Mas eu decidi sair daí, fiquei entediada e fui embora para outro canto. Mas, o problema era que quando eles iam mandar a gente embora, todos tínhamos que ir juntos a ocupar um outro prédio. Eles nos obrigavam a ir, mas eu não ia. Eu me escondia ou fugia. Uma vez fiquei quase dois meses sem conseguir trabalhar. Por exemplo um dia eu estava pronta para sair trabalhar na rua e um encarregado do prédio não deixava ninguém sair... você tinha que ir com eles a tomar um novo prédio. Então eu ficava pressa sem poder sair a trabalhar, por isso as vezes dissimuladamente eu fugia ou me escondia. No prédio tinha moradores que gostavam de mim e eles veiam que eu não queria ir a ocupar porque precisava trabalhar então me ajudavam a esconder-me no elevador. Ficava escondida no elevador e quando todos iam embora eu subia no meu quarto e trancava a porta com cadeado. Sempre fazia isso, nenhuma vez fui. Eu precisava trabalhar! Quando era tempo de ocupar outro prédio ficávamos muito tempo assim, todos os dias sem poder sair, só indo a ocupar o prédio que nos indicavam. Então a gente ficava tenso por não poder trabalhar e ao mesmo tempo com essa preocupação de ter que procurar um lugar para morar, imagina você, para onde ir?! Todo mundo andava assim, procurando, porque nos disseram que esse era o ultimo prédio que as pessoas poderiam ocupar. Inclusive a gente fez uma protesta com barracas e tudo lá nessa ponte fora do shopping Ligth, perto da prefeitura. Aí a gente ficou como duas semanas dormindo em barracas. Mas eu fui dormir lá só uma vez. Eu pensava- "não! vou ficar doente se eu dormir aqui na rua todos os dias na barraca, eu vou embora!". Eu ficava na barraca um tempo, ficava sentada aí para que os dirigentes me viessem e depois ia embora. E assim, depois disso tudo eu pensei "não! Não posso estar assim, preciso de uma tranquilidade para poder trabalhar". Eu precisava estar mais tranquila, e assim foi como fui embora das ocupações. Minha sobrinha me diz um dia que conhecia um peruano que estava procurando pessoas para dividir um espaço que ele tinha, acho que era a metade de um apartamento que ele queria dividir com outros. 
Então eu aceitei e inclusive dei um dinheiro para ele alugar esse espaço. Eram 350 reais que estava cobrando, então me pareceu bem. No fim das contas eu não consegui ir naquele espaço porque o peruano já tinha avisado a outro amigo dele com seu filho para ir, e também eu. Então éramos cinco pessoas nesse espaço pequenino (risos). Estava aquele rapaz com seu filho, uma menina e aquele outro peruano que me avisou, comigo já éramos cinco pessoas, três homens e duas mulheres em um quarto só! E o espaço não era tão grande! (risos). Aí eu falei para ele - "não, quero mais não. Não vou mais morar lá, eu só preciso de um lugar para colocar minhas maquinas e trabalhar". Então eu dormia no prédio e depois ia trabalhar nesse outro espaço. E assim foi como comecei a costurar naquele lugar.

Há pouco tempo, decidi me mudar nesse espaço onde estou agora. Quando eu cheguei aqui estava tudo muito bagunçado um monte de lixo amontoado nos quartos, na sala. Eu arrumei tudo, coloquei este tapete, fiz um armário com as coisas e materiais que achei aqui mesmo. Agora aqui estamos pagando 1300 reais neste apartamento, mas divido com meu amigo, a gente trabalha junto e assim eu já tenho um apoio.

\section{"O que eu quero é viver como gente"}

Eu não tenho nenhum objeto que me lembre de casa, nenhuma coisa que trouxe de lá. Porque como eu estou de ambulante não tenho uma casa fixa, que tenha uma sala, um comedor onde ter minhas coisinhas. Aqui os espaços eu uso só para dormir e trabalhar, não tenho coisas. Como te explico... a maioria das pessoas de fora vivemos em habitações. Na mesma habitação a gente cozinha, dorme, trabalha... vivemos economicamente para nos manter. Aqui a moradia é muito cara e temos que trabalhar para pagar isso. Eu acho que assim é com todos os estrangeiros que chegam... aqui é só para trabalhar e dormir. Porque se eles querem comprar uma casa, isso da para fazer só no seu próprio país, por exemplo, eu já tenho casa no Peru, lá posso ter uma casa e viver melhor por isso... mas aqui é só para trabalhar. Estabilizar-me para sempre aqui é impossível porque estou praticamente sozinha, mas lá no Peru eu tenho minha família, meus afetos. Aqui eu ainda me sinto instável, não tenho estabilidade para ter um lugar. Tal vez mais para frente, quando tenha estabilidade, possa viver como gente, né. Isso é o que eu quero, viver como gente. 
Cesar

\section{"Eu dormia e cozinhava no mesmo quarto... era tudo muito apertado"}

Antes de chegar ao Brasil eu sabia onde ia ficar porque esse meu amigo que me contato me diz: - "eu te dou casa, te dou tudo, você só tem que trabalhar". Eu cheguei em janeiro, em época de muita chuva, cheguei direto na estação Tiete, onde meu amigo foi me procurar, a gente veio para o lugar onde ele ficava e onde eu ia morar. Chegamos assim numa ocupação no centro. Esse lugar onde eu morei um tempo era uma casa abandonada, aí eu trabalhava e morava, tudo na mesma habitação. Dai um amigo me diz para comprar um pequeno quarto dentro de um prédio que estava ocupado. Já dai sai e fui alugar um quarto também no centro da cidade.

Aquele lugar onde eu morei era uma ocupação, uma casa abandonada onde eu morava e trabalhava. Quando eu tive que sair da casa desse amigo me disseram "querem vender um quarto para você". Era um peruano que tinha-se apropriado dessa casa abandonada e estava vendendo os quartos. Ele me vendeu o quarto por 1200 reais, aí eu fiquei quase um ano. Então eu sou o dono desse quarto, mas eu não durmo mais aí, não o ocupo. Uso o lugar geralmente para receber outros peruanos que chegam e assim ajuda-os, tem muitos meninos que vem e não tem onde ficar. Eu não lhes cobro nada, eles podem ficar nesse quarto até eles conseguir um lugar onde ficar. Eu falo para eles "você pode ficar aí, mas não pode fumar, beber e fazer coisas ruins, senão você vai embora" então eles cooperam. Eu saí daquele quarto porque o espaço ficou muito pequeno para mim. E como eu cozinhava e preparava a comida no mesmo quarto, num fogãozinho pequeno do lado da minha cama, todas minhas coisas ficavam cheias de gordura. Foi assim como, junto com dois amigos peruanos, alugamos um apartamento onde moro atualmente. É assim como eu moro aqui.

Sara

Quando eu cheguei, eu morei numa ocupação... essas invasões que fazem os brasileiros. Eu morava num prédio no centro. Mas era complicado porque você ficava no prédio por 4 ou 5 meses e daí eles tiravam você daí e te levavam para outro prédio e assim... Eu fiquei assim em dois prédios... fiz duas mudanças. Minha experiência morando em ocupações foi terrível... as pessoas são muito ruins, muito sujas. Quem me deu a ideia de morar lá foi meu tio. Ele morava numa ocupação e assim que eu cheguei 
ele me diz para morar ali mesmo. Nesse prédio moravam pessoas de todos os lugares, peruanos, colombianos, haitianos, bolivianos, dominicanos... qualquer um que chegasse.

Tem alguns prédios que são decentes, mas tem outros que... $\mathrm{Na}$ real, nesses prédios chegam pessoas muito humildes, mas ao mesmo tempo que são humildes são viciados também, são pessoas de baixos recursos e da mal viver, pessoas mal comportadas, sem educação, muito sujas, tem filhos só por ter. Me disseram que o governo lhes paga 300 reais mensais por cada filho, então tem filhos descontroladamente e nem cuidam deles. As famílias fumavam pedra... não, minha experiência foi horrível, não gostei. Eu fiquei assim seis meses, três meses em cada prédio. Na real, nesses prédios tem diferentes movimentos. Eu nunca pertenci nesses grupos... não são movimentos sociais. São grupos de pessoas que fazem isso por dinheiro, são malandros. Por tomar um lugar nesse prédio eles cobram um dinheiro para você ficar. Quando os brasileiros ocupam um desses prédios, o governa dá para eles um dinheiro. Além disso, os encarregados cobram a cada um 200 reais por quarto, assim eles sacam como 20000 reais por mês. Eu vejo isso mais como um negocio, eles não fazem isso de graça, eles cobram todo mundo... é mais um negocio. Em fim, morei vários meses nessas ocupações, mas daí não quis mais e tentei alugar um quarto. Fomos morar em quatro pessoas todas num quarto só, daí duas pessoas foram embora e ficamos só duas no quarto... aí morei quase um ano. Há pouco tempo foi que mudei aqui no Brás, uns amigos me disseram - "Sara, tem um quarto livre aqui, vem morar com a gente, você gostaria?". E na verdade é que lá é muito confortável, tem cozinha, lavanderia, sala, comedor... e assim mudei para lá.

O aluguel aqui é muito caro, né. Um quarto por esta região esta em torno de 600, 700 reais, só o quarto. Por isso muitos fazemos deste jeito: alugamos entre todos um apartamento ou uma casa e entre todos pagamos o aluguel, assim temos mais facilidade para usar a cozinha, lavanderia, sala... é mais confortável. Pelo contrario, se você mora num quarto só, você vai ter que compartilhar um banheiro com 15 pessoas... é complicado.

\subsection{Análise das entrevistas}

Nas entrevistas realizadas com os imigrantes comerciantes da feirinha de madrugada, a questão de moradia foi um tema muito relevante ao ser motivo de grande 
preocupação, angustia e incerteza nos entrevistados, expressados através dos seus depoimentos no momento de falar sobre as principais dificuldades afrontadas na sua chegada à cidade. Devido a não contar com o dinheiro suficiente para alugar uma habitação assim como a grande incerteza de não ter um emprego levaram os imigrantes a procurar diversas estratégias para satisfazer suas necessidades de vivenda.

As redes de familiares e amigos, no caso dos imigrantes, são de grande importância na sua chegada ao país. Em termos de moradia, as redes brindam apoio e auxilio tanto para receber o imigrante recém-chegado, quanto para hospedar e alojar o tempo que seja necessário até o novo imigrante se estabelecer economicamente e achar um emprego que lhes permita se manter na cidade e assim encontrar um lugar para morar, geralmente dividindo com outros imigrantes conterrâneos uma habitação ou um apartamento pequeno. Cabe ressaltar que antes de empreender a viagem, todos os imigrantes possuem já uma rede estabelecida no lugar de destino, sendo que essa rede foi um fator determinante para decidir imigrar ao lhes oferecer maior segurança de que serão acolhidos.

Os imigrantes entrevistados já sabiam onde e quem os hospedaria, já que na maioria dos casos, a proposta de hospedagem esta ligada à proposta de trabalho. Exemplo disso é o caso de Cesar, quem chegou ao Brasil com uma proposta de emprego - proposta e não contrato de fato- como ajudante de cozinha. Dita proposta estava dentro do pacote de proposta oferecido comumente aos imigrantes: casa, comida e emprego. Esse é o caso mais comum da maioria dos peruanos que chegam ao Brasil aceitando os empregos de "ajudante" - ajudante de cozinha, ajudante de costura, ajudante de vendas - onde o empregador geralmente é responsável também por oferecer um lugar para dormir e um prato de comida em troca de horas exaustivas de trabalho. Passado um tempo, alguns imigrantes conseguem se tornar independentes economicamente, conseguindo outros empregos em melhores condições, produzindo sua própria mercadoria, vendendo roupa ou comida na rua por conta própria e, com o passar do tempo ir poupando de a poucos para comprar ou alugar um box dentro de um mercado popular, ou abrir um pequeno restaurante de comida.

Deste modo, os imigrantes melhor estabelecidos logo de um tempo, com trabalho e um lugar alugado para ficar, servem como novos hospedeiros dos conterrâneos que futuramente chegarão na mesma situação que eles, por conseguinte a rede de acolhida segue a sua sequencia, onde os imigrantes antigos oferecem espaços nas suas habitações para os recém-chegado ficar, os receberão nos seus apartamentos e 
acolherão e mostrarão algumas regiões da cidade da mesma maneira com que fizeram com eles. Um exemplo é o vivenciado por Cesar, quem ao sair de uma ocupação no Centro e conseguir uma habitação na mesa zona, usa atualmente o lugar para receber e alojar outros jovens peruanos que, da mesma maneira que ele, chegaram sem dinheiro nem lugar onde poder ficar oferecendo-lhes uma moradia provisória até eles conseguir se estabilizar economicamente e arrumar um lugar melhor.

Já em outros casos, os imigrantes hospedam familiares que trazem ou mandam chamar desde seu pais de origem e assumem com parte das passagens e com toda a hospedagem em troca de que o familiar ajude com o trabalho ou negocio já começado em São Paulo, geralmente esse "favor" tem a ver com ajudar na costura ou nas vendas de rua, como é no caso das feirinhas ou mercados populares constituindo assim uma rede familiar de trabalho. Tal é o caso exposto por Jandy, a qual contata em varias ocasiões a seus familiares para lhes oferecer vir no Brasil e se hospedar na sua casa para ajudar-lhe na venda de mercadoria na feirinha de madrugada ou na costura das peças.

Por outro lado, a presença de imigrantes e refugiados nas ocupações de luta por moradia em São Paulo é cada vez mais comum e numerosa. São diversos os motivos que levam a esta população a acudir aos movimentos sociais de luta por moradia para resolver a necessidade de um teto para eles mesmo e para suas famílias. Entre os principais motivos encontra-se a falta de documento documentação, desconhecimento dos programas sociais de habitação, renda por debaixo do mínimo, muitas vezes produto do trabalho escravo, praticas discriminatórias e xenófobas por parte dos donos e encargados dos imóveis e empresas imobiliárias.

Assim, devido ao altíssimo custo do aluguel da cidade, com habitações que não baixam dos 500 reais, junto aos escassos recursos com os que chegam e a incerteza de não ter um emprego, levou aos entrevistados a morar diretamente nas ocupações do centro, principalmente porque a rede de familiares e amigos à qual eles faziam parte se encontrava já estabelecida em algum desses prédios.

Existem no centro de São Paulo numerosas ocupações pertencentes a diversos movimentos de luta por moradia como o MTSTC, MTST, FLM, entre outros, cujos prédios tem uma presença considerável de imigrantes e refugiados de diversas partes do mundo os quais, de igual maneira que os ocupantes brasileiros, tem o dever de participar ativamente nas ocupações noturnas em novos prédios, participar das reuniões dentro do movimento e das manifestações por moradia que acontecem no Centro e outras regiões. O grande inconveniente no caso dos imigrantes e refugiados é que 
devido a sua condição, sua sobrevivência na cidade depende unicamente do seu trabalho já que devem ganhar o sustento dia a dia para pagar sua própria comida, enviar dinheiro a sua família e pagar diversas despesas. Os imigrantes comerciantes, costureiros e demais, devem sair nas ruas no horário de madrugada ou cedo de manha para trabalhar vendendo sua mercadoria, ou trabalhando nas oficinas, vendo-se assim prejudicados quando acontecem os atos de ocupação, as reuniões obrigatórias ou as manifestações já que é uma obrigação para todos os ocupantes destes prédios. Tal como relata Jandy, em varias ocasiões se viu impedida de sair durante vários dias do prédio, impedindo assim puder trabalhar na feirinha, o que a prejudicou economicamente ao ficar sem recursos.

Com tudo, as ocupações foram lugares transitórios no caso de todos os entrevistados. Foram espações que lhes possibilitou conseguir uma moradia em condição quase emergencial ao chegar à cidade. Porem, devido ao desconforto e á incerteza própria da dinâmica desses lugares, isto é, constantes mudanças de lugar cada certo período de tempo, é que os imigrantes alguns meses depois decidem deixar as ocupações e alugar imóveis econômicos, geralmente nas regiões do Centro, próximo dos seus centros de trabalho como são Brás, Luz e Bom Retiro, mudança que ao mesmo tempo lhes oferece maior tranquilidade e uma leve sensação de estabilidade.

O caso de Sara é outro exemplo dessa passagem. Depois de ter passado por varias ocupações e ter dividido pequenas habitações com muitos conterrâneos, é que depois de algum tempo e com um pouco mais de estabilidade consegue se agrupar com amigos e conhecidos de idades similares para dividir um imóvel com melhor estrutura e conforto e assim poder viver em melhores condições. Formam assim espécies de "republicas" de jovens conterrâneos vindos de diversas cidades do Peru, na maioria das vezes também dedicados ao comercio. Através de Sara conheci varias dessas republicas situadas nas ruas São Caetano e Aurora, próximo da região da Estação da Luz, conformadas principalmente por jovens entre 18 e 24 anos, homens e mulheres solteiros provenientes da Amazônia e dos andes peruanos. Nessas repúblicas se concentravam jovens dedicados às mais diversas atividades como vendedores ambulantes de roupa, vendedores de sobremesas e comidas, cabelereiros, ajudantes em lojas e ajudantes de cozinha nos restaurantes. Dentro dessas republicas os jovens, embora a dinâmica dos seus trabalhos, dividem as atividades de casa como cozinhar para todos, fazer faxina, ir no mercado, e se preocupar com a situação e problemas do outro.

Por outro lado, é habitual que as habitações provisórias -ou permanentes- que acostumam ser ocupadas pelos imigrantes que chegam nas condições anteriormente 
descritas, caracterizem-se por ser espaços superlotados, isto é, varias pessoas ocupando um só espaço. Nos relatos de Jandy, depois de ter passado por varias ocupações, o primeiro apartamento que decidiu alugar era dividido com mais outras cinco pessoas entre homens, mulheres e uma criança, ficando um espaço muito reduzido e sem conforto. Jandy decidiu assim usar esse espaço só para guardar suas maquinas e ao mesmo tempo como oficina de costura e continuar dormindo nas ocupações. Como pode-se notar, é frequente ver que os imigrantes utilizam suas habitações tanto para dormir quanto para trabalhar. Em casos onde os imigrantes se dedicam ao comercio de rua é comum usar os espaços da sua habitação para guardar a mercadoria, trabalhar na produção ou em casos de venda de comida, cozinhar e dormir no mesmo espaço, reduzindo ainda mais os espaços da sua moradia. 
CAPITULO 5

5. O LAZER DOS IMIGRANTES 


\subsection{O tempo livre na cidade: lugares e atividades de lazer dos imigrantes peruanos}

No campo acadêmico, a temática do lazer tem sido também deixada de lado, ao considerar mais relevante questões relacionadas ao trabalho no cotidiano das pessoas. Por outro lado, as abordagens sobre a temática têm tido sempre como referencia a realidade europeia e americana ignorando o contexto latino-americano e as diversas maneiras das pessoas vivenciar o tempo livre. No artigo $6^{\circ}$ da Constituição Brasileira, o lazer aparece como um direito social, junto á saúde, educação e moradia, assim como o direito a receber um salario mínimo capaz de responder as necessidades das pessoas nas quais o lazer esteja incluso. Por outro lado, é obrigação do estado incentivar o lazer como promoção social a traves de atividades e infraestrutura a ser disponibilizadas ao cidadão. Porem, a diferença dos outros direitos, a Constituição não estabelece objetivos nem diretrizes que posam nortear e concretizar o lazer na vida dos cidadãos.

Historicamente, a diminuição de horas de produção, férias, descansos assim como melhores condições de trabalho e vida foi uma conquista da classe operaria.na qual Dentro dessa conquista, o tempo livre e a possibilidade de usufruir de atividades de lazer, cultura, musica, esporte e demais foi também uma reinvindicação e motivo de luta pelos trabalhadores. O lazer surge assim a partir e como uma oposição ao trabalho, uma dicotomia entre tempo livre versus trabalho, e em muitos casos, é motivo de lucro e rentabilidade por parte de instituições privadas a traves da construção de clubes, academias e demais equipamentos e infraestrutura disponível unicamente para os setores privilegiados da cidade, em outras palavras, um lazer de condomínio. O Lazer vem sofrendo também muitas modificações devido não só á transformação e reorganização do sistema de trabalho, a crescente precarização e terceirização, mas também à tecnologia e virtualidade na vida das pessoas e a sua relação com o mundo.

Para Magnani, (1998) o lazer é um fenômeno que diz muito sobre a vida dos trabalhadores. O autor, a partir de um estudo etnográfico, analisa o mundo do lazer e formas tradicionais do uso do tempo livre de trabalhadores urbanos moradores dos bairros da periferia, espaços geralmente com carência de estrutura adequada e equipamentos necessários para o exercício de atividades de lazer. Não entanto, isto não é impedimento para os moradores, trabalhadores pobres, marginalizados geralmente vindos das regiões do Nordeste, levem a cabo as mais diversas e variadas manifestações culturais no seu tempo livre nos finais de semana, tais como o circo, o futebol de várzea, aniversários, casamentos, excursões de farofeiros, passeios, etc. Todas essas atividades 
estavam profundamente ligadas ao modo de vida, aos costumes da população, e ajudavam a fortalecer os vínculos, a identidade e o reconhecimento da sua própria comunidade. Quando o imigrante se estabelece em um novo lugar, não só tem que velar pela sua subsistência econômica, física e material. Ele também tem que reformular e reconstruir, novos vínculos e laços, novas sociabilidades novas identidades:

Para o imigrante, a mudança não se esgota no problema de uma maior ou menor capacidade de adaptação às exigências do trabalho urbano, mas significa alterações profundas em seu modo de vida, na forma de satisfação de suas necessidades e no aparecimento de novas necessidades. Implica um reordenamento de todo o seu estoque simbólico (op. cit. p.25).

No caso dos imigrantes, as festas populares e demais celebrações constituem um importante fator de estudo para analisar as formas em que as identidades, as tradições, os valores e sociabilidades dos grupos migratórios se recriam, resinificam e reterritorializam a traves de praticas urbanas dentro da metrópole, permitindo-lhes inclusive negociar outros espaços dentro desse contexto (SILVA, 2008).

Assim, o imigrante desenvolve uma relação com a nova cidade, lidando com uma estrutura urbanística totalmente nova e diferente ao lugar de origem e reformulando os mecanismos de sociabilização e construção de redes, assim como novas maneiras de estabelecer vizinhanças. Novos elementos e códigos são incorporados e assimilados, ou reenlaçados ao conjunto de símbolos e códigos trazidos do lugar de origem.

Assim, um aspecto do vivido de muita importância a ser explorada é a maneira como os imigrantes vivenciam seu tempo livre e como, a traves de suas sociabilidades, manifestações culturais, festas, celebrações e demais atividades de lazer, os imigrantes tem a possibilidade de se reterritorializar ocupando diversos espaços da cidade e apropriando-se simbólica e culturalmente do território onde vivem sua experiência migratória, isto é, a metrópole, lugar onde os indivíduos elaboram novas maneiras de pertencimento e identidades (DANIEL, 2014).

Os imigrantes peruanos constroem diversas formas de sociabilidade a traves de laços com outros imigrantes do mesmo pais. Essa constituição de uma rede migratória se consolida a partir de uma reorganização do território no pais de imigração. Devido a que a grande maioria de peruanos que chegam em São Paulo o fazem para trabalhar na rama do comercio em regiões especificas da cidade, os lugares que concentram a grande parte desse grupo estão diretamente relacionados com a sua inserção econômica na 
metrópole. Isto é, lugares específicos onde a moradia é accessível em termos de preço e de proximidade a seus pontos de trabalho.

Estas regiões, no caso dos imigrantes peruanos, são as regiões do centro de São Paulo, como a Praça Republica, Brás, Luz, etc. mas além de constituir-se espaços onde os imigrantes satisfazem suas demandas de trabalho e moradia, estes desenvolvem ao mesmo tempo mecanismos para se sentir parte do espaço estabelecendo diversos outros serviços que satisfaçam outras necessidades, como é o caso dos restaurantes de comida típica do pais de procedência, lugares para realizar ligações ao estrangeiro, empresas de envio de remessas, baladas e bares onde os frequentadores geralmente são outros conterrâneos, lojas de comercio de produtos do lugar de origem, etc. É a partir de esses espaços que os imigrantes têm a possibilidade de construir novas territorialidades no contexto das grandes cidades.

Por outro lado, as formas dos peruanos aproveitarem o seu tempo livre na cidade, os lugares que frequentam e as atividades especificas que realizam, assim como as sociabilizações, seguem as referencias trazidas do lugar de origem e são resinificadas no novo pais. Desse modo, a comunidade estabelece categorias e hierarquias que tem a ver com gênero, idade, raça e condição socioeconômica, as quais condicionam a maneira de construir vínculos entre os conterrâneos e os outros e o modo de ocupar a cidade. Dentro da comunidade de peruanos, existe também uma distinção respeito ao acesso e maneiras de vivenciar as atividades de lazer, assim como os modos de socializar e agrupar-se entre si. Encontra-se assim grupos de peruanos que se juntam por ter diversas condições em comum, como desenvolver o mesmo tipo de atividades econômica ou de estudos, proceder da mesma cidade ou região de origem, pertencer à mesma classe socioeconômica, fazer parte da mesma rede de relações com seus conterrâneos, etc. Assim as atividades têm também uma especificidade espacial, onde por exemplo, os estudantes peruanos se agrupam e sociabilizam entre eles em regiões próximas da universidade, lugar onde eles moram e estudam; de igual maneira os peruanos comerciantes se agrupam em regiões próximo a sua moradia e trabalho. 
Figura 5: Restaurante peruano no centro da cidade de São Paulo

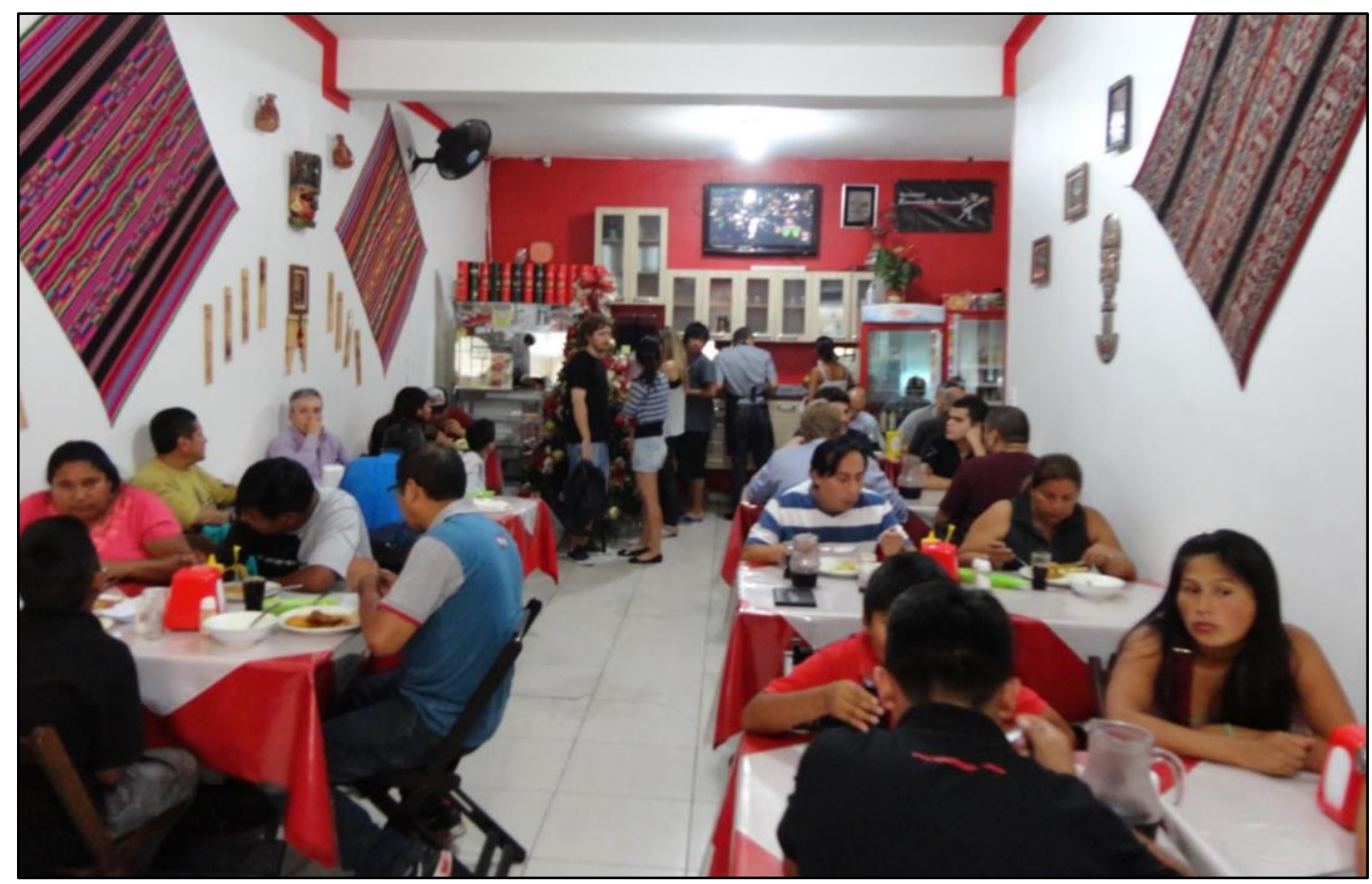

Fonte: http://www.timeout.com.br/sao-paulo/restaurantes/venues/812/rinconcito-peruano

A partir de visitas realizadas nas regiões com alta presença de esses imigrantes, informações de outros peruanos morando na cidade e das entrevistas a profundidade realizadas aos comerciantes, corroborou-se que é o centro de São Paulo o ponto principal que concentra e reúne a grande parte de peruanos chegados à cidade. Entre os bairros y regiões do Centro, são as ruas Rio Branco, Guaianases e Santa Cecilia, São Joao, que concentram os restaurantes de comida típica de Peru, quadras esportivas, bares e baladas onde os frequentadores são basicamente peruanos e também imigrantes de outros países vizinhos. Um hábito muito comum dos peruanos, independente da situação socioeconômica, é comer aos domingos fora de casa e sair para almoçar ou jantar num restaurante. Os restaurantes são muitas vezes o ponto de encontro para se reunir com os amigos, almoçar e jantar com os familiares nos finais de semana e um lugar para se sentir como em casa.

Para os peruanos, as atividades realizadas entorno à comida como cafés da manha, almoços, jantas, são um bom motivo para renuir amigos, familiares, vizinhos e colegas de trabalho. Os hábitos alimentícios junto ao universo de cheiros, sabores, cores e texturas de prato de comida estão carregados de símbolos e significados e constituem um importante veículo de conhecimento sobre nossas tradições e a nossa historia, revelando também componentes da nossa identidade. Desse modo, para os peruanos que 
se encontram longe da sua terra de origem, é muito importante a preservação da sua cultura a traves da comida e todos os processos de preparação da mesma, como a utilização de temperos, a produção e a maneira de distribuir as raçoes entre as pessoas presentes. Os ingredientes utilizados para a elaboração da comida são imprescindíveis e são muitas vezes trazidos do próprio pais em alguma visita, trazidos por encomenda com algum familiar ou amigo que esteve no país recentemente ou são também comercializados em zonas conhecidos por vender todo tipo de produtos peruanos e bolivianos nas férias e mercados como é a Rua Coimbra em qualquer dia da semana, ou os domingos na feria boliviana na Praça Cantuta. Nos grupos da comunidade peruana em São Paulo nas redes sociais como Facebook é muito comum ver anúncios de integrantes do grupo vendendo ingredientes peruanos trazidos do país, do mesmo modo, vários peruanos encontram-se vendendo comida típica e oferecendo-a a traves dessas redes virtuais, as quais podem ser encomendadas por delivery fazendo pedidos via WhatsApp com antecedência, tal como o realiza Cesar, um dos comerciantes cozinheiros entrevistados na presente pesquisa.

\subsection{Narrativas dos e das peruanas imigrantes}

\section{Jandy}

Eu não frequento lugares muito afastados, mas não se trata do dinheiro. Porque eu sou uma pessoa que gosta de comer bem, gosto das coisas boas, dos bons lugares, eu estou acostumada com isso. A questão é que a gente não conhece lugares distantes daqui. Podemos ir tal vez na Paulista. Um dia a gente foi para lá porque nos disseram que tinha um restaurante peruano e como a gente queria conhecer fomos para lá, só que não sabíamos nem o nome da rua nem o endereço exato. No final a gente foi num outro restaurante na Avenida São Joao.

Eu vou comer na Rio Branco, vou nos restaurantes peruanos. A gente vá também no Pari quando uma amiga nos convida na sua casa. As vezes vamos aos shoppings daqui do centro. Assim um pouco para distrair-nos. Mas a gente tenta ir em lugares perto daqui, né, porque mais longe eu não conheço. Ouvi dizer que tem um parque bonito, grande, mas que fica muito longe daqui. tal vez algum dia a gente vá para lá. 
A gente, na real, prefere ficar aqui pelo centro. Mas geralmente pelo cansaço do trabalho nem vontade de sair tenho. Pelo contrario, eu descanso no domingo. É demasiado cansativo trabalhar de madrugada. Mas as vezes fico tão entediada de ficar aqui que digo "não... vamos na Rio Branco a ver se tem alguma coisa para fazer". Porque ficar por aqui também é muito entediante, é pelo trabalho que eu faço. Eu não acostumo ir em festas. As vezes fazem festa de aniversario e me convidam, mas nunca vou. Como já eu te falei, o trabalho da noite e madrugada é muito cansativo... você não tem vida. Os sábados, por exemplo, eu descanso... aproveito para descansar. Domingo eu aproveito para lavar roupa. Às vezes, alguns domingos meus sobrinhos me convidam a almoçar na casa deles, visito eles para comer alguma coisa. Com todos os camelos da feirinha que conheço é assim. Com quase todos é assim. Eles mesmos também me dizem que não tem vida, que isto não é vida... que se sentem entediados e querem voltar para o Peru e trabalhar lá.

\section{Sara}

Eu saio muito pouco, mas essas poucas vezes que saio gosto de ir ao cinema com minhas amigas, gosto de sair a comer alguma coisa no centro. A gente gosta de sair a comer anticuchos no centro, perto da Rio Branco, onde tem restaurantes peruanos. Nos finais de semana agora não saio muito, antes saia mais. A gente ia muito numa balada peruana chamada Salsa Discoteque, é a única que tem na cidade, fica no centro também. Domingo a gente fica mais em casa, ou então, vamos tomar café da manha na Rio Branco, lá vendem de manhã comida peruanas como caldos e sopas. Eles vendem essas comidas na rua aí na Rio Branco, a gente chama de agachaditos, lá tem muitos peruanos comendo na rua sentados nas calçadas, as vezes tem alguns equatorianos também. A gente geralmente frequenta só o centro. Às vezes vou para Paraisópolis, lá tem muitos peruanos também. É uma favela onde moram muitos peruanos, geralmente trabalhavam como babás, ou então cuidando casas. A gente, com meus amigos, vamos também na praia. Quando é temporada de verão a gente vai nas praias próximas. Tem uma praia onde tem um museu de animais... nessa praia a gente vai. 


\section{Cesar}

Teve um tempo, quando eu me separei do meu amigo e comecei a morar sozinho, ia sempre a visitar um casal de amigos peruanos que moravam por Francisco Morato, na zona oeste. Eles sempre me convidavam na sua casa e eu ia até lá a visita-os seguido, eu me sentia num ambiente mais familiar. Depois eles se mudaram no interior e aí eu fiquei sozinho. Daí eu saia com uma menina brasileira que morava na Guaianases e eu andava por aí, mas eu já conhecia essa região então tranquilo.

Os finais de semana eu fico mais em casa, saio muito pouco... Eu jogo mais futebol. Com outros peruanos nos reunimos para jogar futebol nas terças, quartas e quintas. A gente joga sempre numa quadra na Guaianases ou senão em uma outra quadra chegando na estação Luz. Alugamos essas quadras e jogamos, assim a gente descarrega. As vezes jogo futebol com meus clientes do Brás, mas eles são muito exigentes e se você erra em algum passe eles começam a gritar, são um pouco bravos. Além disso não gosto muito de jogar com eles porque são os mesmos que vejo todos os dias. Em cambio quando jogo na Guaianases é mais brincadeira, não conheço muito as pessoas e é mais leve, todos nos cumprimentamos e faço novas amizades.

Igualmente quando fui pela primeira vez nessa discoteca peruana Salsa, na época vendia comida na rua Guaianases, as pessoas me convidavam para ir nessa balada, meus amigos me diziam para ir, e eu só fui pela primeira vez depois de ano e meio. Essa primeira vez eu pense "eu vou para ver outro mundo, mudar de ambiente, ver outras pessoas". Que nada! Fui e me encontre com um cliente, com outro que me comprou fiado, com outro que me sacaneou. Achei as mesmas pessoas que vejo tudo dia. Fui uma vez e dai não fui mais, só vou quando chegam grupos peruanos de musica.

Aqui os peruanos bebem mais que vikingos. Bom, os que eu conheço bebem muito. Quando estou com uma menina só estou com ela, não saio, não vou para baladas, não bebo. Quando estou sozinho bebo, vou jogar futebol com meus amigos. Mas a maioria de jovens ou senhores bebem, por exemplo meus companheiros de casa bebem todos os dias. Se tiveram um bom negocio bebem, se não foi bem na Feirinha bebem, se a policia confisca suas mercadorias bebem. Eu acho que é a nostalgia. Tem muitos que escutam alguma musica que lhes lembra de casa o da família e por nostalgia começam a beber. 


\subsection{Análise das entrevistas}

A partir das narrativas, confirmamos que em geral os entrevistados não frequentam regiões muito afastadas dos seus lugares de moradia, assim que as atividades que realizam no seu tempo livre nos finais de semana acontecem mais nas regiões acima descritas. Os imigrantes realizam também visitas a outros familiares e amigos conterrâneos nos finais de semana e feriados, organizam comidas, aniversários e passeios, quase sempre num lugar próximo do centro como shoppings, cinemas e restaurantes.

Na entrevista com Sara, se constatou que é a Rua Rio Branco a zona onde ela frequenta com seus colegas, amigos e companheiros de casa, lugar aonde acostumam ir todos juntos a tomar café da manha nos finais de semana. Desde as sete da manha de todo domingo, nessa rua se concentram vários cozinheiros peruanos para vender na calçada comidas típicas que fazem parte do café da manha peruano, como caldos, sopas, ceviches, quinua, entre outros, e onde os assistentes são sempre peruanos, bolivianos e equatorianos, chamados também de agachaditos por degustar sentados na calçada os pratos típicos.

Devido a que o grupo de amigos de Sara, são jovens comerciantes entre os 18 e 24 anos, dispõem de mais energia para realizar passeios e excursões de ida e volta no mesmo dia às praias mais próximas como Santos o Guarujá em temporada de verão; ou então realizam visitas grupais para visitar outros amigos e conhecidos conterrâneos que se encontram morando em outras regiões, como é no caso da favela Paraisópolis, lugar onde muitos jovens peruanos vivem e trabalham de babás, cuidando casas ou como empregadas domesticas. O mesmo grupo de amigos também realiza celebrações e festas em casa, assim como frequentar juntos uma balada peruana chamada Salsa, principalmente em feriados e no aniversario de algum amigo.

Um ponto de encontro dos jovens peruanos é um local situado na região de Santa Cecilia chamado La Salsa Discotek, balada administrada por imigrantes peruanos onde todo final de semana se oferece diversão ao ritmo de musica latino-americana, como salsa, bachata, merengue, cumbia, entre outros; ademais de saborear as bebidas típicas do Peru. O Lugar tem uma alta assistência não só de peruanos, como também de imigrantes de regiões próxima como bolivianos, colombianos, paraguaios. No lugar se realizam também shows em vivo com grupos de musica conhecidos convidados e trazidos diretamente do Peru e outros países da América Latina. Em dias festivos 
segundo o calendário peruano, realiza-se shows especiais com musica afro peruana e ritmos populares do Peru.

Outra atividade muito praticada por imigrantes peruanos nas suas horas de lazer é o futebol. Nos dias da semana e sobretudo sábados e domingos, grupos de peruanos se reúnem para jogar o famoso fulbito, nome que no Peru se da ao futebol amistoso jogado entre colegas, vizinhos, companheiros de escola e amigos; e que se joga sempre em lugares pequenos e accessíveis como na rua ou terrenos baldios do bairro, em quadras dentro de alguma escola, em uma quadra de algum centro esportivo, etc. Já no contexto de São Paulo, o fulbito continua sendo praticado pelas crianças, jovens e adultos imigrantes, sendo quase sempre uma atividade exclusiva dos homens; situação diferente no caso dos imigrantes bolivianos, os quais tem uma presença significativa das mulheres nesse esporte, competindo em campeonatos integrando times de futebol só de mulheres e treinando nas mesmas quadras dos homens.

Em São Paulo, uma das quadras mais conhecida por alugar e disponibilizar suas instalações entre as comunidades de imigrantes de bolivianos, peruanos colombianos, paraguaios e equatorianos é um local situado no segundo andar de um prédio na Rua Guaianases, no centro da cidade. O nome da quadra é Arena Central, e ganhou muita popularidade entre a comunidade imigrante devido ao baixo custo do aluguel, por ser um lugar próximo das regiões de moradia e trabalho dos assistentes e por organizar diversos campeonatos e torneios anuais que inclui a participação de imigrantes de diversos países. 
Figura 6: Quadra esportiva Arena Central situada na rua Guaianases no centro de São Paulo

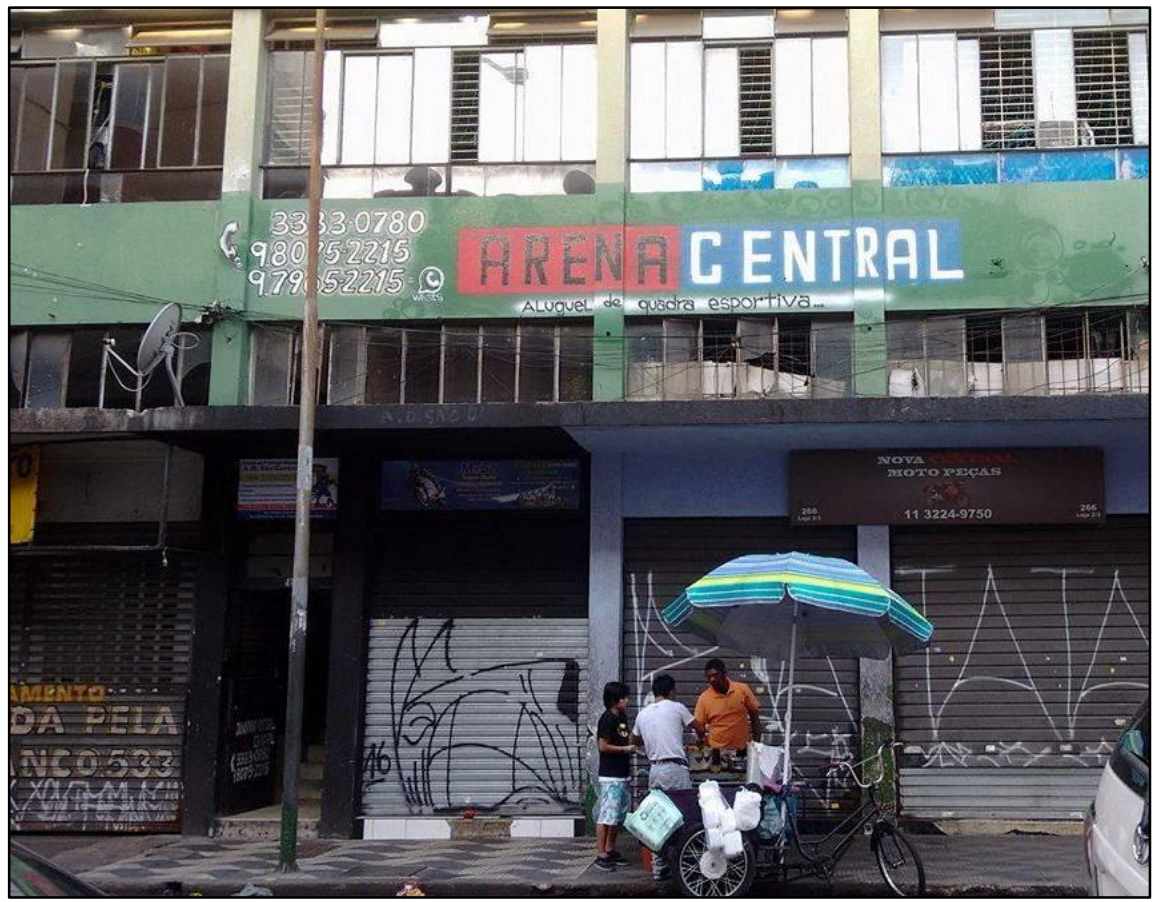

Foto: Autoria própria.

Diariamente nos horários da tarde e noite, imigrantes de origem latino-americana e cuja ocupação é no comercio ambulante, nos restaurantes e nas oficinas de costura, se concentram na quadra de futebol e demais instalações do local para jogar futebol, sociabilizar com outros imigrantes, amigos e colegas e assim descontrair-se um pouco da pesada rotina de trabalho. Nas redes sociais como Facebook, encontram-se de maneira mais detalhada algumas informações sobre essa quadra esportiva, onde os administradores divulgam as datas dos próximos campeonatos, compartilham as fotos e vídeos dos eventos principais e dos treinos diários e publicam os quadros com os resultados de cada jogo. Na pagina principal da quadra no perfil de Facebook, pode se ler a seguinte frase: "Arena Central, Fazendo as coisas cada dia melhor por el bem del futebol de salão para os imigrantes no Centro -SP”.

$\mathrm{Na}$ entrevista com Cesar, corroborou-se que as quadras de futebol são espaços onde os imigrantes sociabilizam com outros conterrâneos e imigrantes de outros países, geralmente vizinhos, companheiros de casa, amigos e colegas e conhecidos da mesma região e ramo de trabalho, como por exemplo da área de cozinha, das feiras de madrugada, dos mesmos boxes, oficinas de costuras, etc. Nas palavras de Cesar, as tardes jogando fulbito na quadra é um momento para fazer novas amizades com outros imigrantes que trabalham em outras ramos de trabalho na região central, e também é um 
espaço para "descarregar" a pressão e estresse da própria rotina de trabalho, da preocupação sobre sua condição econômica na cidade e descarregar a tristeza de estar longe da família o as sua terra natal.

É importante ressaltar que, como se observou na dinâmica de trabalho dos peruanos trabalhadores da feirinha de madrugada, a organização do seu tempo e do dia a dia gira entorno basicamente ao horário de trabalho, horário que, pela sua condição de ambulante em horário de madrugada, é muito exaustiva. Entre as 2 e 10 da manhã os imigrantes dedicam-se ao comercio, restando o resto do dia e da tarde para descansar, comer, organizar a mercadoria e no melhor dos casos socializar com amigos e familiares. Casos em que os imigrantes, se dedicam a outras atividades laborais além do comercio, como costura e cozinha, o tempo restante para o descanso e qualquer atividade de tempo livre e sociabilização é ainda menor. O caso de Jandy é um bom exemplo disso. Por trabalhar como ambulante na madrugada e costurar de tarde e noite, o cansaço e a fadiga dessa rotina fazem com que ela prefira ficar em casa nos finais de semana para descansar, dormir e cuidar do asseio da casa; suprimindo a sua disposição física e emocional para sair a passear e conhecer a cidade, encontrar amigos e familiares, e sociabilizar com outras pessoas. Jandy afirma que como ela, outros imigrantes camelos experimentam a mesma sensação de "não ter vida", disposição nem tempo para sair, interagir com outras pessoas no seu tempo livre devido à dinâmica de vida e trabalho.

\subsection{As polladas e os campeonatos de futebol: duas celebrações populares na comunidade imigrante}

Durante os quatro anos que moro em São Paulo tive a oportunidade de assistir em reiteradas ocasiões às festas peruanas celebradas na cidade. Essas celebrações são maiormente organizadas pelo consulado peruano em São Paulo, junto a ONGs que trabalham com imigrantes e conta também com a presença do cônsul peruanos e outras autoridades, assim como empresários peruanos residentes em São Paulo e que auspiciam algum premio no sorteio ou algum grupo musical. Entre essas festas oficiais estão as celebradas no dia da independência peruana no mês de julho, as quais são realizadas no local da escola de Samba Águias de Ouro no bairro Barra Funda e que reúne a peruanos e peruanas imigrantes independente da sua ocupação e situação na 
cidade. Outra atividade organizada pelo consulado é a Yunza ou carnaval andino, realizado no centro esportivo Tiete, tem quase a mesma dinâmica da festa anterior e culmina com os assistentes dançando arredor de uma arvore cheia de presentes e surpresas. Estão também as celebrações pelo dia da mãe peruana, dia do Señor de los Milagros e Dia de la Musica Criolla, onde os peruanos podemos assistir um show de musica e encontrar amigos e conhecidos.

As grandes atrações dessas festas são, em definitiva, as numerosas bancas de comida distribuídas em todo o local, onde os peruanos podemos saborear uma grande variedade de pratos típicos, sobremesas e bebidas típicas. Essas bancas devem seguir certos requisitos e normas impostas pelos organizadores para conseguir ter um espaço na festa e vender seus produtos. Em um momento da entrevista com Cesar, vendedor ambulante de comidas, me contou a dificuldade que atravessam muitos cozinheiros e cozinheiras peruanas para aceder a um espaço no local e poder vender sus pratos de comida, segundo ele, por não ter os contatos suficientes ou não ser donos de restaurantes de comida peruana reconhecidos.

Por outro lado, durante a entrevista com Sara, antes de começar a descrever as celebrações e atividades de lazer do seu circulo social, ela destacou uma divisão entre o lazer popular e as celebradas pelo consulado, reconhecendo-se dentro de um grupo social como "os outros peruanos" para falar das suas próprias festas e modos de vivenciar o lazer na cidade, vejamos:

[...] as duas festas principais são o Señor de los Milagros e as festas que fazem pelo dia da independência do Peru, essas são as principais. Tem uma outra festa que fazem que também é conhecida, se chama Yunza ou carnaval andino. Também fazem um concurso do Ceviche, essas são as oficiais. Mas os outros peruanos fazemos outras festas, fazemos polladas, festas, a maioria são por aqui por Brás. Fazemos torneios de futebol, fazemos aniversários. Tem uma quadra de futebol aqui na Guaianases e aí os peruanos jogam futebol, fazem suas competições (Sara).

A partir da narrativa de Sara nota-se que as celebrações da comunidade peruana na cidade dividem-se para os imigrantes, entre as festas oficiais e as do povo ou como ela considera, festa dos "outros peruanos" fazendo alusão a suas próprias festividades e celebrações que não guardam relação com instituições e consulado. Essas ultimas atividades de lazer são frequentadas geralmente por peruanas e peruanos comerciantes, cozinheiros, vendedores ambulantes, costureiros e empregados de pequenos restaurantes. E são justamente essas festas populares as que se tentou conhecer e 
descrever na presente pesquisa por estar estreitamente ligadas aos processos de territorialização e as dinâmicas de sociabilização no contexto da imigração.

Depois das entrevistas com os imigrantes e traz mostrar interesse por conhecer as festas da comunidade e demais, não faltaram convites para participar das celebrações, passeios e festas familiares de amigos e vizinhos, as quais aceitei com muita alegria e gratidão. Festas de aniversario, polladas, jogos de fulbito, tardes de café e saídas na Salsa Discoteque, foram as atividades que teve a sorte de participar. Com o tempo, fui adentrando e conhecendo pouco a pouco as atividades de lazer e maneiras de socializar dos peruanos imigrantes, principalmente dos comerciantes ambulantes e cozinheiros; e ao mesmo tempo, conhecendo muitos outros jovens chegados de diversas regiões da Amazônia e dos Andes, todos com as mesmas expectativas de mudar as suas condições de vida.

As duas atividades de lazer relatadas a continuação, foram baseadas na minha participação em duas celebrações, ambas levadas a cabo no ano 2016 e em companhia de dois dos entrevistados. Uma delas foi uma Pollada celebrada nas instalações de um centro esportivo do bairro Paraisópolis. A outra foi um campeonato de futebol chamado "Copa Futsal Latinoamericana de Imigrantes no Centro- SP" no local da quadra esportiva Arena Central, na região central da cidade.

\section{Polladas: celebrações populares da comunidade peruana em contexto de imigração}

As Polladas $^{7}$ são celebrações populares que servem como uma estratégia de sobrevivência em tempos de crise económica e política no Peru e teve seu auge na década dos anos 1990 nas grandes cidades do pais, principalmente em Lima. Essas atividades estão vinculadas aos valores de reciprocidade, solidariedade e intercâmbio herdados dos povos andinos, lugar de procedência dos imigrantes internos chegados à capital.

Desde a década dos anos 1980 a raiz da violência politica, começa uma imigração massiva para Lima desde diferentes regiões do Peru, especialmente as áreas mais pobres e com maior vulnerabilidade de violência do estado e dos grupos subversivos, isto é, as regiões da Cordilheira dos Andes. Uma vez estabelecidos na capital, esses habitantes começaram a contatar outros conterrâneos a través de anúncios na radio e no jornal para

\footnotetext{
${ }^{7}$ Uma pollada é um prato de comida a base de frango temperado frito, acompanhado de batatas e milho cozido, salada e molho de pimenta.
} 
formar assim "clubes de provincianos", onde realizavam atividades de venda de comida em benefícios da comunidade e membros do clube, assim como para arrecadar dinheiro e enviar a sua terra natal (BEJAR: ALVAREZ, 2010).

Com a formação das barriadas $^{8}$ em Lima, foram as mulheres atoras principais para afrontar e superar a crise de desemprego, escassez e pobreza pela que atravessavam as famílias assentadas nos novos bairros ocupados, onde além de trabalhar como empregadas domesticas, se organizaram em associações destinadas à arrecadação de dinheiro para o abastecimento e implementação de serviços básicos de agua, luz, esgoto, pavimentação dos seus próprios bairros. Levaram a cabo também outras atividades como a venda de comida, atividades esportivas, realização de almoços e polladas em beneficio da comunidade. Formaram também importantes organizações como os comedores populares e os Comités del Vaso de Leche, ambos tinham como função garantir a alimentação básica das famílias com escassos recursos e, sobretudo às crianças pequenas de zero a seis anos de idade e às mães gravidas e em fase de lactação de recursos insuficientes.

Além de todas essas estratégias coletivas, as polladas aparecem também como uma forma de aliviar a crise e contribuir com a renda familiar. Estas festas são celebradas entre vizinhos, amigos e familiares para a arrecadação de dinheiro e assim custear uma operação ou tratamento medico, financiar a construção ou acabamento de uma casa, arrecadar dinheiro para uma associação o grupo sindical, ajudar na economia de uma família que afronta o desemprego, entre outras necessidades imediatas.

As polladas acontecem principalmente no final de semana, sendo sábado o dia preferido da celebração. Os preparativos começam com varias dias de antecipação primeiro para desenhar e imprimir as cartilhas-convide com o nome dos organizadores, motivo, lugar e data sendo importante colocar "tarjeta aceptada, tarjeta pagada" no final da cartilha. O convide é entregue a cada uma das famílias, amigos, vizinhos, colegas de trabalho, companheiros de estudo e se faz questão de lembra-lhes um o dois antes do evento. A musica é um elemento fundamental na polladas, onde os assistentes podem dançar ao ritmo da salsa, tecnocumbia, huayno, chicha, merengue, rock, entre outros" (op. Cit. p.270). o consumo de bebidas alcoólicas, principalmente cerveja é

\footnotetext{
${ }^{8}$ Chamados também de "assentamentos humanos", são bairros periféricos formados a partir de ocupações de famílias e povoadores pobres na capital, principalmente chegados das regiões dos Andes e que, na maioria dos casos, chegavam a Lima fugidos do conflito Armado e da extrema pobreza.

${ }^{9}$ Em português: cartilha recebida, cartilha paga.
} 
outro elemento fundamental. A mesma se bebe em grandes quantidades o que poderia explicar as habituais brigas, conflitos, discussões de casal, etc. entre os espectadores.

Figura 7: Cartilha convite a uma Pollada realizada em Lima com motivo de saúde

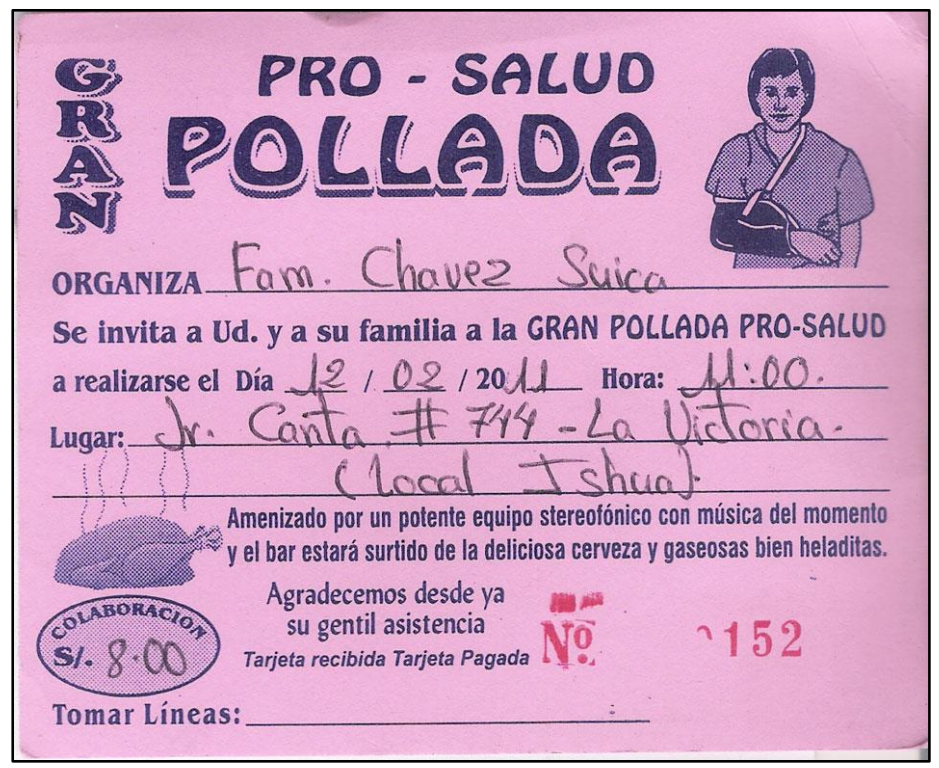

Fonte: http://sd-ishua.blogspot.com.br/2011/02/pollada-pro-salud-familia-chavez-suica.html

Figura 8: Pollada com motivo de financiar gastos com a justiça contra a entrada de empresas mineradoras no povoado de Chacralla

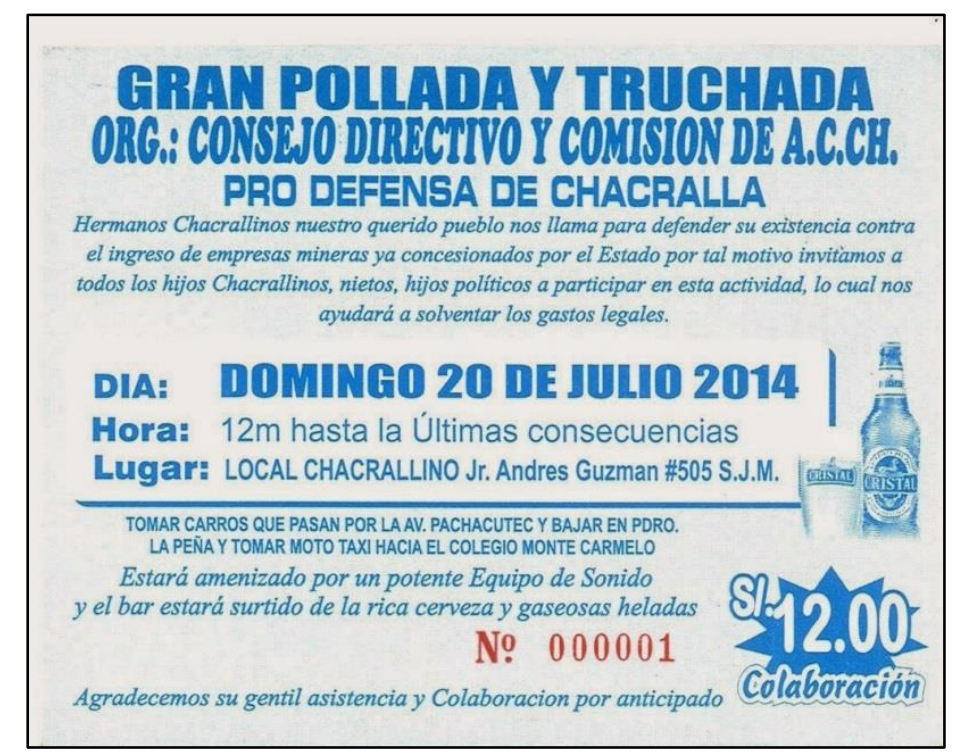

Fonte: https://chimaycha-chacralla.blogspot.com.br/2014/07/gran-pollada-y-truchada-pro-defensa-de.html

Devido aos avanços tecnológicos e á difusão das redes sociais, as cartilhas antes entregues em físico e de porta em porta nos vizinhos do bairro, hoje são virtuais e 
compartilhadas nas redes virtuais como Facebook, Instagram, blogs e grupos de Whatsapp. Mesmo assim, não perdem o sentido solidário e de ajuda mutua. Pode-se encontrar recentemente divulgações de polladas em grupos de Facebook par a arrecadação de dinheiro para ajudar aos danificados dos desastres naturais ocorridos no Peru no transcurso do 2017, principalmente os afetados por inundações, e deslizes. Em uma cartilha achada nas redes sociais encontra-se a seguinte mensagem:

Pollada Solidaria Damnificados Rio Chillon.

Convocamos a c/u de uds. vecinos, vecinas, compañeros, hermanos a colaborar con esta pollada solidaria que tiene como objetivo cubrir las necesidades más fundamentales de todos los vecinos del Río Chillón. Apelamos a la solidaridad popular, la única capaz de desarrollar la unidad del pueblo contra la explotación capitalista neoliberal de la cual la política municipal de Comas viene aplicando con hostigamiento y negando a más de 250 familias su derecho fundamental a la vivienda. ¡Viva la solidaridad del pueblo peruano!. ipor nuestro derecho fundamental a la vivienda! ¡reconstrucción con y para el pueblo! ¡subvención económica para todas las familias damnificadas! ¡crédito cero para recuperar todo lo perdido! ¡abajo la explotación capitalista neoliberal! ${ }^{10}$

É importante também mencionar todo o preconceito formado em torno das polladas, não só no Peru, como também fora do país, preconceito que fui percebendo ao encontrar outros latino-americanos no Brasil que me comentavam desse tipo de celebrações como algo ridículo e de baixo nível. Esse preconceito se deve às ideais difundida pelos meios de comunicação, formando no publico assistente um imaginário carregado de preconceito e estigma sobre essas festas, deslegitimando a noção de ajuda mutua e formas comunitária de sobrevivência que caracteriza dita festa.

As polladas foram também cenário de crimes que comoveram o país no começo dos anos 1990, fase onde a violência politica se acentuo consideravelmente nas regiões urbanas do país, principalmente em Lima. No dia 3 de novembro de 1991, em uma zona chamada Barrios Altos, na região central de Lima, se encontravam celebrando uma pollada mais de 20 pessoas entre homens, mulheres e crianças, com o objetivo de arrecadação de dinheiro para a reparação e melhoramento do sistema de esgoto do bairro. Foi assim que as 22:30 horas, duas camionetas estacionaram-se fora do evento, de onde desceram entre seis a dez pessoas armadas com metralhadoras e o rosto encoberto, irromperam no quintal da casa onde se celebrava a pollada e com gritos e

$10 \quad$ Fonte: https://allevents.in/provincia\%20de\%20lima/pollada-solidaria-damnificados-riochillon/2282214875337741. Acessado em 28 de Novembro de 2017. 
golpes obrigaram aos assistentes a deitar no chão boca abaixo, onde posteriormente atiraram nas cabeças e costas das pessoas. Segundo dados da Comision de la Verdad y Reconciliacion (2003), quinze pessoas e uma criança de oito anos foram executadas no fatídico evento. Os responsáveis implicados, além dos técnicos e suboficiais do exercito, participantes diretos no assassinato, foram agentes do serviço de inteligência do exercito, o assessor do ex-presidente Fujimori e generais do Comando Conjunto de las Fuerzas Armadas; todos eles foram condenados no ano 2001 a 25 anos de pressão por crimes de lesa humanidade.

Figura 9: Pagina principal de um jornal peruano no dia seguinte do massacre em uma pollada em Lima

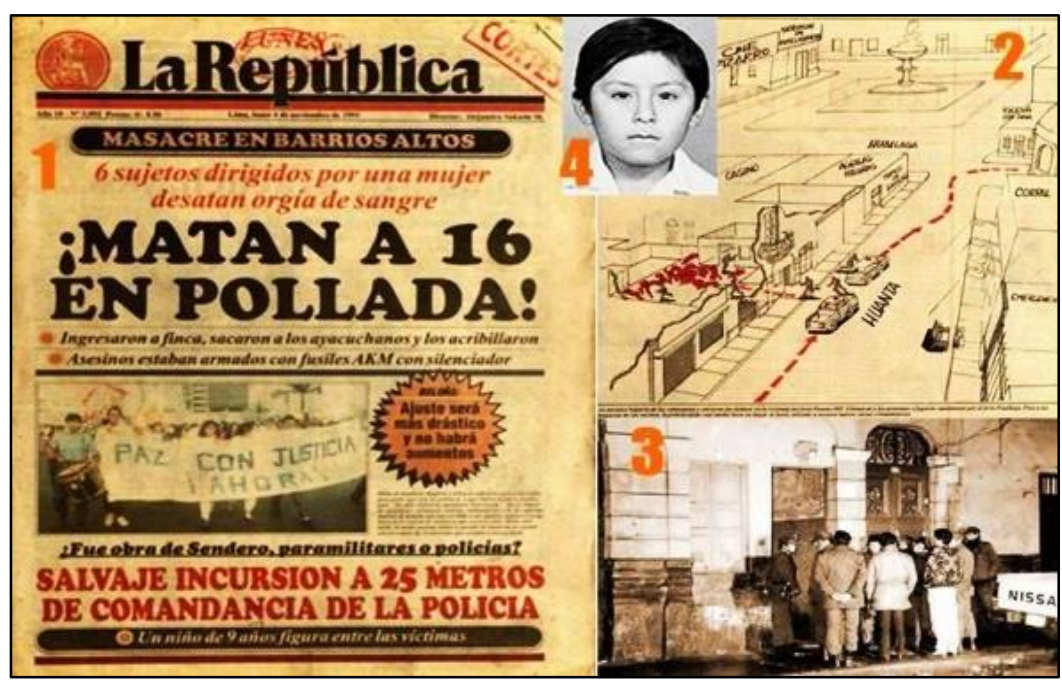

Fonte: http://www.capital.com.pe/actualidad/matanza-en-barrios-altos-el-tragico-recuerdo-de-los-16muertos-en-1991-noticia-842460.

Figura 10: Passeata dos caixões com as pessoas assassinadas na matança de Bairros Altos em Lima

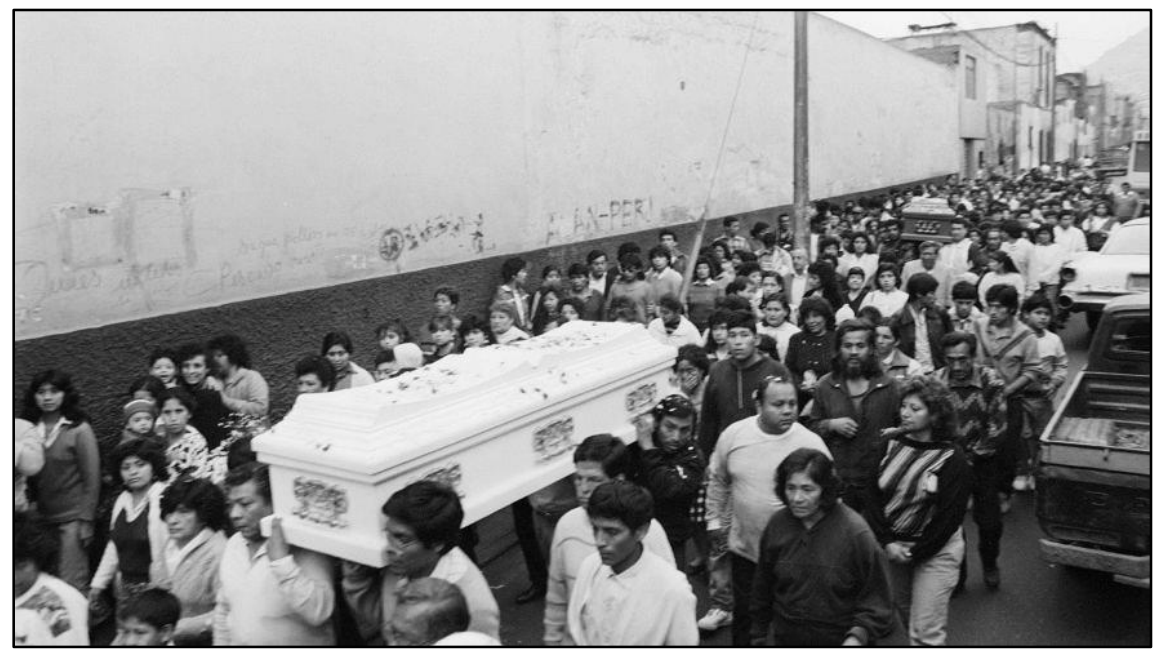

Fonte: http://archivo.elcomercio.pe/politica/actualidad/barrios-altos-hoy-se-cumplen-24-anos-atentadonoticia-1853242/2. 
Com tudo, as polladas, além de ser um mecanismo de sobrevivência, fazem parte da vida social das pessoas e grupos e constitui uma atividade de tempo livre, principalmente nos finais de semana. É um espaço muito importante de sociabilização e confraternização entre famílias, amigos, colegas e vizinhos das classes populares. Um momento para ouvir e dançar musica típica das suas regiões de origem, reencontrar pessoas distanciadas, etc. $\mathrm{O}$ que foi incialmente uma celebração própria dos imigrantes internos deslocados às grandes cidades, constitui na atualidade um espaço importante de resgate das tradições da cultura popular para os peruanos que saíram do Peru e migraram na procura de novas oportunidades de vida, tal como mostra o seguinte texto sobre a comunidade peruana no Equador:

Os assuntos festivos são também aspectos que se vivem nas regiões fronteiriças. Tal é o caso da pollada, que é uma tradição peruana e uma reunião dançável onde se consome cerveja. A pollada é organizada pelos 170 membros da "Asociacion de Peruanos Residentes en Machala". Três polladas se realizaram no ano 2003, o 16 de junho, o 28 de julho pelo aniversario da independência peruana, e a finais de outubro em honor ao Señor de Los Milagros. (LOPEZ, 2004 como citado em BEJAR \& ALAVAREZ, 2010)

Assim como no Equador, levam-se a cabo em diversas partes do mundo esta celebração popular por parte da comunidade peruana residente. Algumas delas são organizadas pelos consulados e associações de residentes peruanos, outras são celebradas pelos próprios trabalhadores, famílias, grupos de amigos e colegas de estudo e os lugares são geralmente as próprias casas, nas calças dos bairros onde habitam, quadras de futebol e espações públicos como escolas e centros esportivos.

Tive também a oportunidade de participar a outras polladas celebradas por peruanos na cidade de São Paulo, sendo varias delas no meu lugar de moradia, o conjunto residencial universitário da USP (CRUSP), lugar onde tem uma presencia considerável de peruanos e peruanas vindos de diversas regiões do Peru, e cujo motivo de chegada é a realização de estudos de pós-graduação. As polladas realizadas no CRUSP também mantiveram o sentido solidário que as caracterizam. Motivos como arrecadação de dinheiro para comprar as passagens de volta para o Peru ou simples arrecadar dinheiro como ajuda para costear a vida na cidade uma vez acabados os estudos, bolsa de auxilio ou poupanças, reuniram peruanos e peruanas na cozinha coletiva do bloco $\mathrm{C}$ para degustar a deliciosa polladas, ouvir musica peruana e compartir um momento agradável com todos. 
Duas semanas depois da entrevista com Sara, recebi por mensagem a traves de Facebook um convite da sua parte para assistir em uma pollada, em companhia dos seus amigos e companheiros de casa, a data do evento estava marcada para outubro de 2016 no bairro Paraisópolis. Traz aceitar o convite, combinamos em encontrar no começo da tarde fora do Metro Faria Lima, onde pegaríamos o ônibus até o lugar. Assim chegando na estação Faria Lima encontrei a Sara no ponto, não passou muito tempo para que o ônibus com letras grandes PARAISOPOLIS chegara, e, com o assombro de Sara dizendo - "que surpresa! Nunca vi este ônibus vazio!" - nos subimos rapidamente. Os seus amigos já tinham partido minutos antes para a festa, devido que a grande maioria deles participaria na competência de futebol e vôlei, atividades programadas como parte da pollada.

No percurso do caminho até nosso destino, sara me comentava um pouco sobre a sua vida aqui em São Paulo, sobre os seus amigos e conhecidos moradores de Paraisópolis e a frequência com a que seus companheiros de casa se reuniam com amigos de bairros mais distantes. Ela me contou também os planos para viajar na praia com seus amigos, passeio que fazem uma vez por ano em época de verão até a praia mais próxima como Guarujá, onde levam comida, bebidas e passam o dia até o final da tarde. Em quanto isso, a gente observava pela janela a mudança da paisagem desde o esvaziado e sem vida bairro de Morumbi até adentrar no bairro Paraisópolis, um grande contraste próprio de cidades tão grandes e ao mesmo tão desiguais como São Paulo. Desde o ônibus conseguíamos ver muitas crianças correndo e brincando na rua, casas muito pequenas e coloridas, barracas com comida de rua, senhores lavando o carro e carros com aparelhos de som e algumas pequenas lojas de bairro. Chegando quase ao ponto final do ônibus, descemos e caminhamos alguns minutos até encontrar o lugar onde se levaria a cabo a pollada. O local era um centro esportivo municipal, um espaço muito grande com varias quadras de futebol e vôlei. No lugar tinha também muita movimentação, com crianças brincando em todos os espaços e jovens sentados nas grades de concreto conversando. As quadras de futebol encontravam-se ocupadas por jovens e adultos peruanos, todos agrupados em times de futebol e alguns com seus respetivos uniformes da seleção peruana.

Na quadra de vôlei, situada do lado esquerdo na quadra de futebol, estavam agrupadas as mulheres, jovens e senhoras com roupa esportiva jogando vôlei. Outro grupo de mulheres se encontrava no mesmo espaço cuidando dos bebes em quanto seus maridos jogavam futebol e bebiam cerveja na quadra do lado. Na parte do fundo, entre 
ambas quadras, estava montada uma pequena barraca com alguns fogões e mesas onde se preparava a polladas, motivo principal da festa. Do lado dos pequenos fogões encontrava-se uma mesa com recipientes grandes que continham os demais ingredientes do prato como batatas cozidas, salada, molho de pimenta e do lado, uns bloques de caixas com cerveja bem gelada pronta para ser consumida pelos assistentes.

Figura 11: Senhores peruanos na preparação da pollada em Paraisópolis

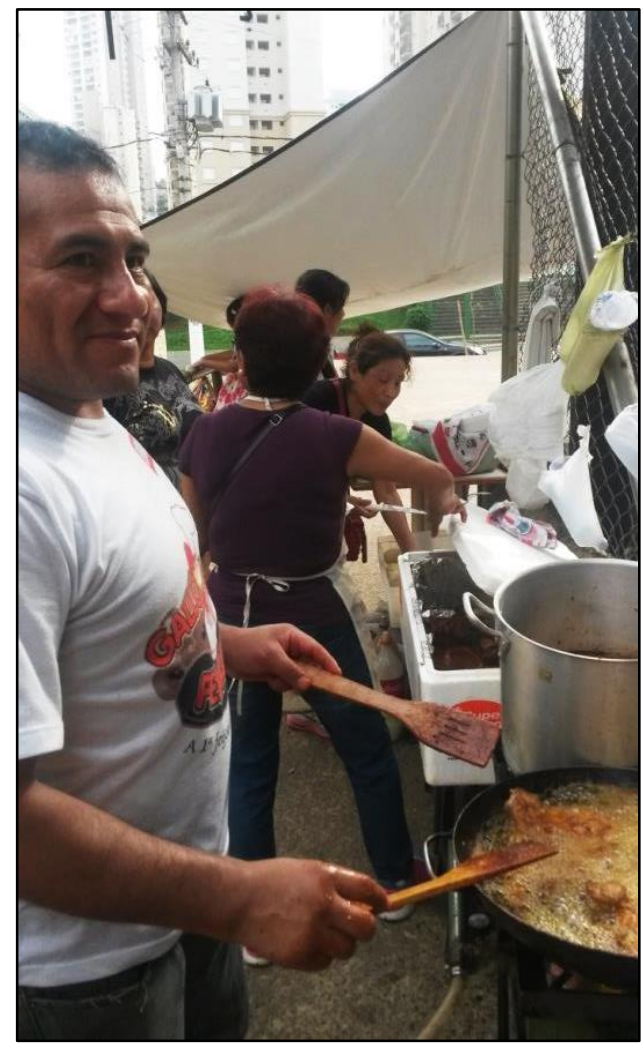

Fonte: Própria autoria

Figura 12: Preparação de uma pollada em Paraisópolis

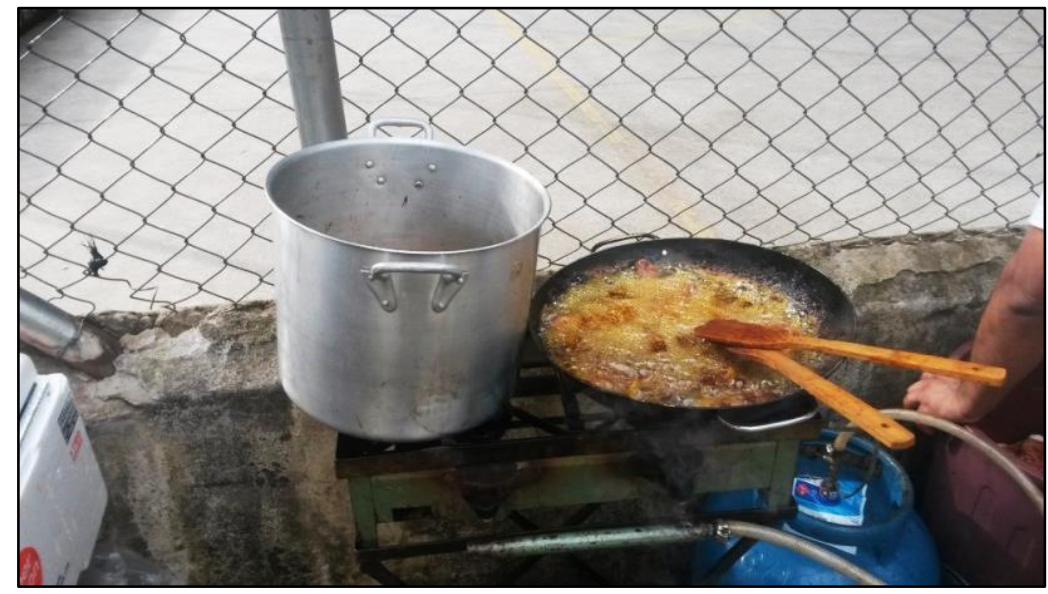

Fonte: Própria autoria 
Alguns minutos depois de dar algumas voltas no local procurando os amigos de Sara, os achamos e nos juntamos a eles. Eram aproximadamente quinze jovens entre homens e mulheres e se encontravam todos sentados na arquibancada esperando seu prato de pollada ficar pronto e assistindo os jogos de futebol dos outros peruanos. Todos esses jovens se mostraram muito amáveis e sociáveis e curiosos por saber de que cidade eu era, há quanto tempo que estava no Brasil e o que estava fazendo aqui. A maioria deles tinha entre 18 e 25 anos e provinha de diversos lugares do peru, como da Amazônia, Arequipa, Cusco e outras cidades dos Andes; e dedicavam-se em São Paulo a diversas atividades como, cabelereiros, ajudantes de cozinha, vendedores em lojas de chineses, babas de crianças e, a maior parte, comerciantes ambulantes da 25 de março e do Brás vendendo roupas, acessórios e sobremesas típicas peruanas. Depois de algum tempo de interagir, comer a pollada e descansar, os jovens começaram a se alistar para entrar a competir com outro time de peruanos.

No evento, percebi imediatamente a divisão dos assistentes em quanto a gênero. Os homens ocupando a maior parte do local, bebendo muito cerveja, falando e gritando muito alto, e comandando a musica e os jogos. E por outro lado a mulheres, sempre sentadas vendo seus maridos, amigos, e colegas jogando, sem beber já que era obrigação delas cuidar das crianças em quanto os homens jogavam, bebiam e interagiam. Algumas das mulheres jogavam vôlei, esporte exclusivo das mulheres no Peru. Cabe mencionar a grande diferença com a comunidade boliviana, na qual a presença das mulheres no futebol é muito ativa, onde jovens e senhoras bolivianas se reúnem para treinar principalmente no bairro Bom Retiro e participam ativamente de competições e campeonatos como jogadoras. 
Figura 13: Imigrantes peruanos assistindo jogo de futebol em Paraisopolis

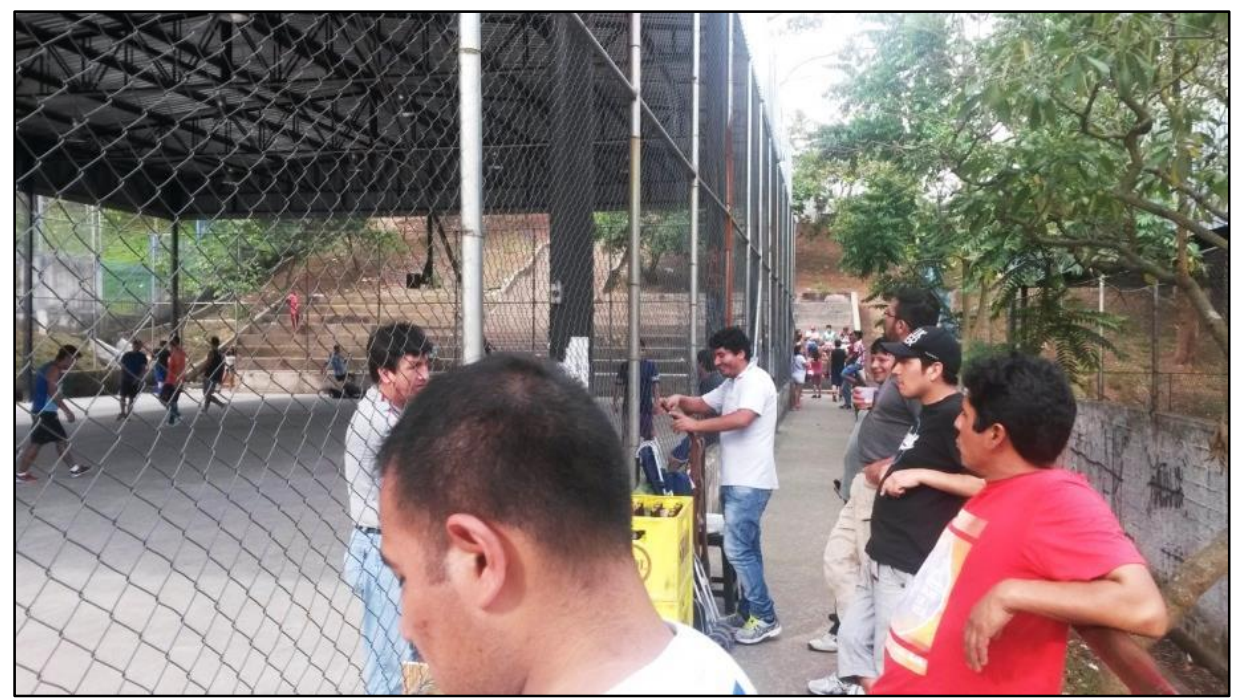

Fonte: Própria autoria

Figura 14: Peruanos assistindo jogo de futebol em Paraisópolis

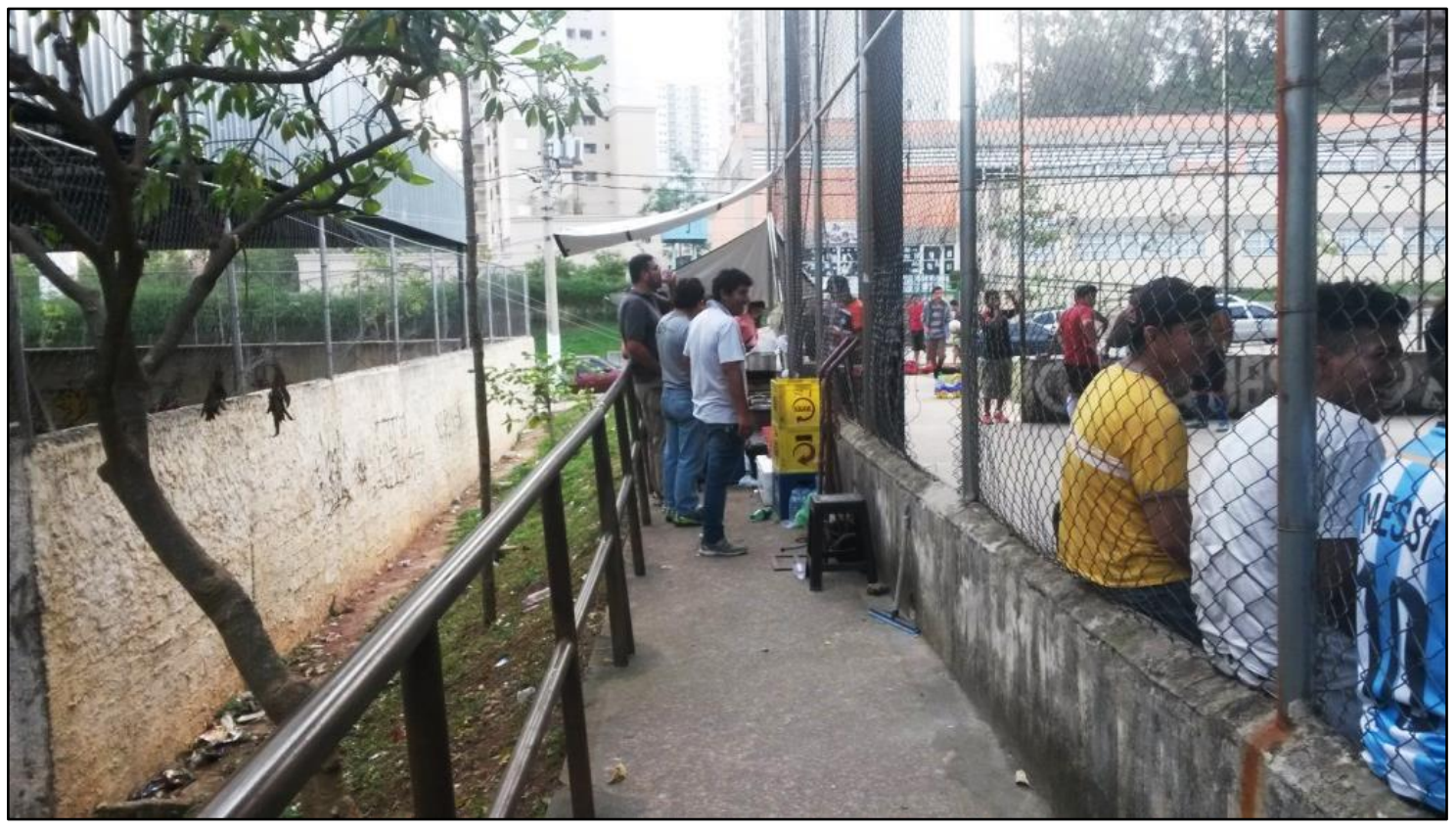

Fonte: Própria autoria

\section{Futebol no Arena Central}

A partir das narrativas dos entrevistados é que se coletou informação sobre as principais atividades de lazer dos peruanos na cidade. Uma dessas atividades comentada pela maioria são os jogos de futebol. Para muitos imigrantes, ter a oportunidade de se reunir entre amigos e competir amistosamente com outros conterrâneos ou com 
imigrantes de outros países constitui uma dimensão importante da sua vida social em contexto migratório. O jogo como manifestação de lazer, significa também para os imigrantes, um veículo para construir sociabilidades e ampliar assim suas redes. (DANIEL, 2014).

Uma das atividades lúdicas comentada pela maioria de peruanos foram os jogos, campeonatos, torneios e treinos de futebol, atividade de lazer muito habitual não só na comunidade peruana levadas a cabo não só pela comunidade peruana, como também boliviana, paraguaia, equatoriana e colombiana. O lugar escolhido e de mais fácil acesso aos imigrantes trabalhadores do centro que desejam praticar essa atividade é a uma quadra situada próxima ao bairro Republica no centro de São Paulo. A quadra esportiva, que tem como nome "Arena Central”, esta situada próxima da Rua Aurora e Rio Branco, ruas conhecidas por concentrar a maioria de restaurantes peruanos, assim como colombianos e africanos, e cujos frequentadores são imigrantes das mais diversas nacionalidade e brasileiros. $\mathrm{O}$ local se caracteriza por organizar em diversos momentos do ano, campeonatos, treinos e torneios para os imigrantes de todas as idades e nacionalidades, sendo o evento mais importante o realizado no mês de novembro de cada ano, sempre no dia domingo e que reúne a famílias inteiras principalmente da região de América Latina. Dito evento leva o nome "Copa Futsal Latinoamericano Centro- SP", um evento muito difundido nas redes sociais de peruanos e bolivianos e na própria conta de Facebook do Arena Central, onde também pude acompanhar as fases eliminatórias antes do esperado evento.

Figura 15: Cartaz com informações previas do Campeonato Latinoamericano

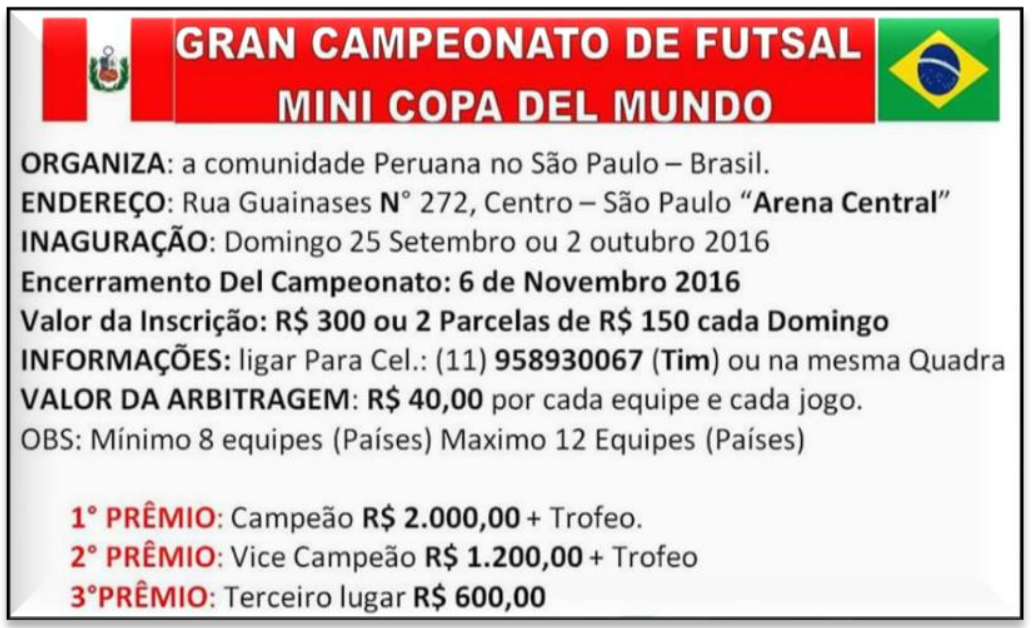

Fonte: Facebook Arena Central. 
No dia domingo 27 de novembro desse mesmo ano, desde as onze da manha se deu inicio ao campeonato latino-americano. Desde a rua de frente já podia se observar a quantidade de famílias com crianças e grupos de amigos que começavam a chegar no local, todos muito animados e com muita presa para entrar. Encontrava-se na mesma calçada próximo da porta principal a imprescindível comida de rua vendida em carrinhos, o que no Peru se conhece como comida de carretilla, a qual estava sendo vendida por uma família de peruanos que se encontravam preparando alguns pratos peruanos para os assistentes famintos antes de entrar na quadra.

O publico empezou a chegar desde o meio dia para arrumar um lugar confortável para assistir as competições de futebol. A plateia, composta de dois andares vendia-se também comida típica peruana como a pollada, refrigerante e doces peruanos, além de grande quantidade de cerveja. No mesmo tempo, já podia se identificar as torcidas da Bolívia, Colômbia, Peru, Paraguai e do Brasil. Todos agrupados em famílias e amigos e organizando-se para alentar o time do seu país. Os competidores eram de todas as categorias, começando pelos times de crianças competindo com outros times de outras nacionalidades; tinha também times de mulheres adolescentes bolivianas competindo com o time das jovens paraguaias; e estavam também os adultos de diversos países competindo da mesma maneira.

Nos intervalos de cada jogo, os assistentes aproveitavam para fazer filas e comprar os pratos de comida, da mesma maneira com a cerveja e doces para as crianças. Os adultos e jovens aproveitavam para procurar amigos e familiares e cumprimentar-se entre conhecidos de maneira alegre e calorosa. As crianças aproveitavam os espaços livres da quadra para brincar com outras crianças e correr de um lado a outro.

Depois de varias horas de intensos finais de jogo, os organizadores mandaram colocar em alto volumem cumbia peruana em quanto montavam o que seria a área de premiação da copa latino-americana. Precisou-se de quatro grandes mesas de plástico para colocar a quantidade de troféus a ser entregados ao primeiro e segundo lugar de cada categoria, além de uma certa quantidade de dinheiro aos times ganhadores. A premiação, ultima parte do evento foi um momento muito emocionante entre os assistentes, principalmente para as crianças ao receber os troféus por ter participado e na presença dos emotivos pais e mães. Seguido das adolescentes bolivianas orgulhosas de ter levado o primeiro lugar da sua categoria e pelo seu desempenho na quadra e, finalmente, os times dos homens adultos, onde os peruanos levaram grande quantidade de troféus para casa. 
Figura 16: Seleção boliviana de futebol feminino juvenil. Campeonato Latinoamericano de futsal, Arena Central- São Paulo

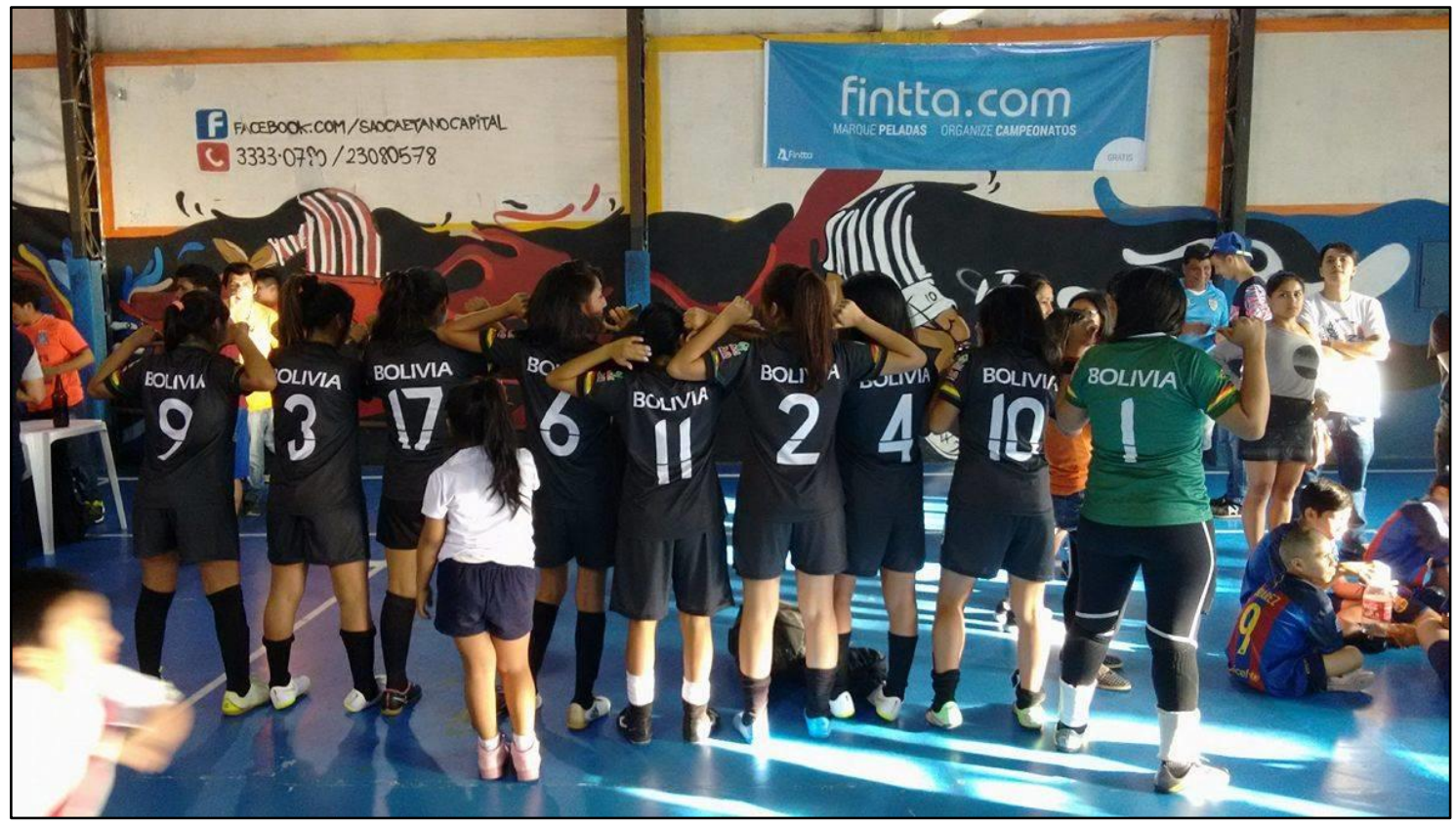

Fonte: Própria autoria.

Figura 17: Seleção de jovens peruanos nos jogos eliminatórios para o Campeonato Latinoamericano

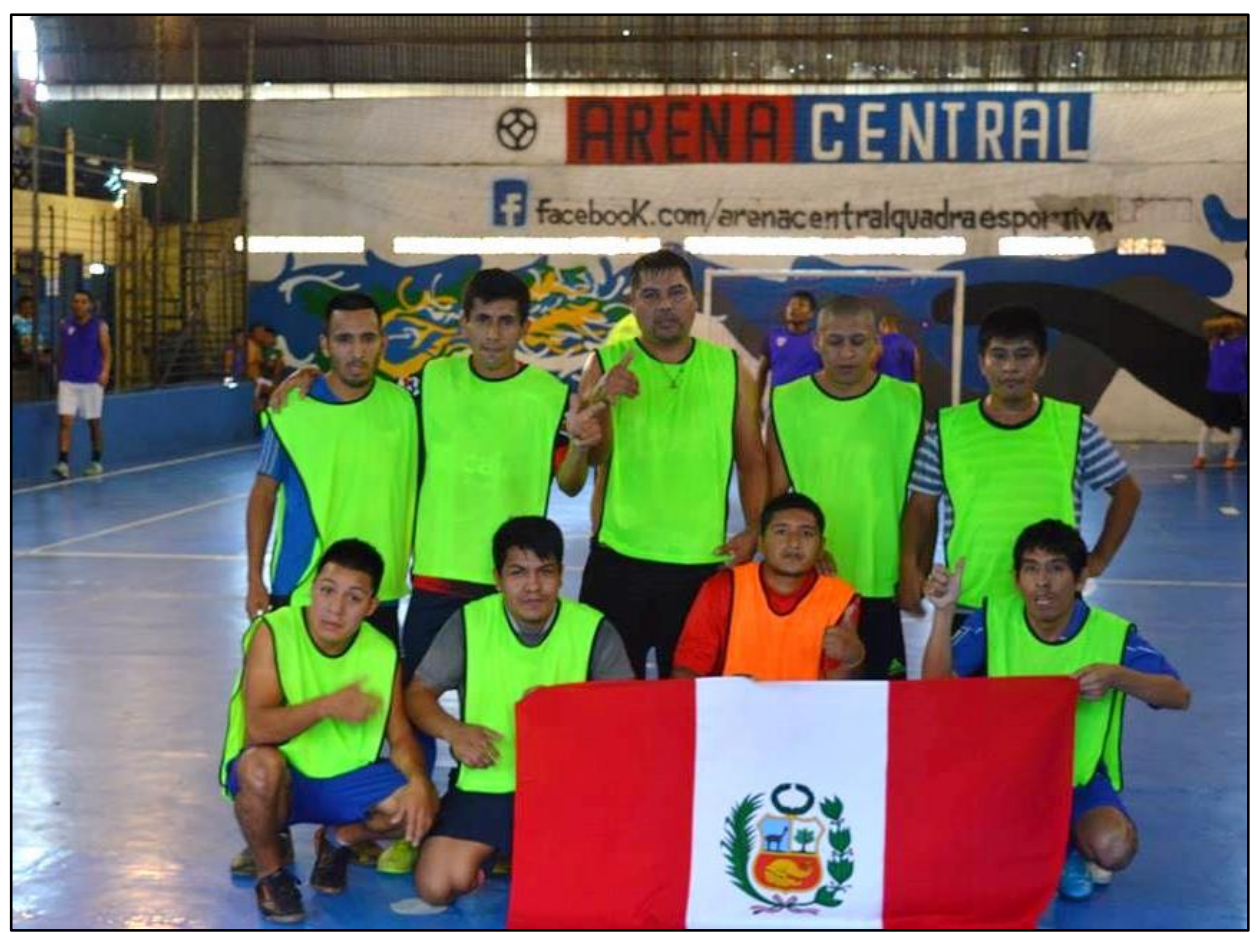

Fonte: Facebook no Arena Central 
Figura 18: Espectadores e torcedores apoiando seus times

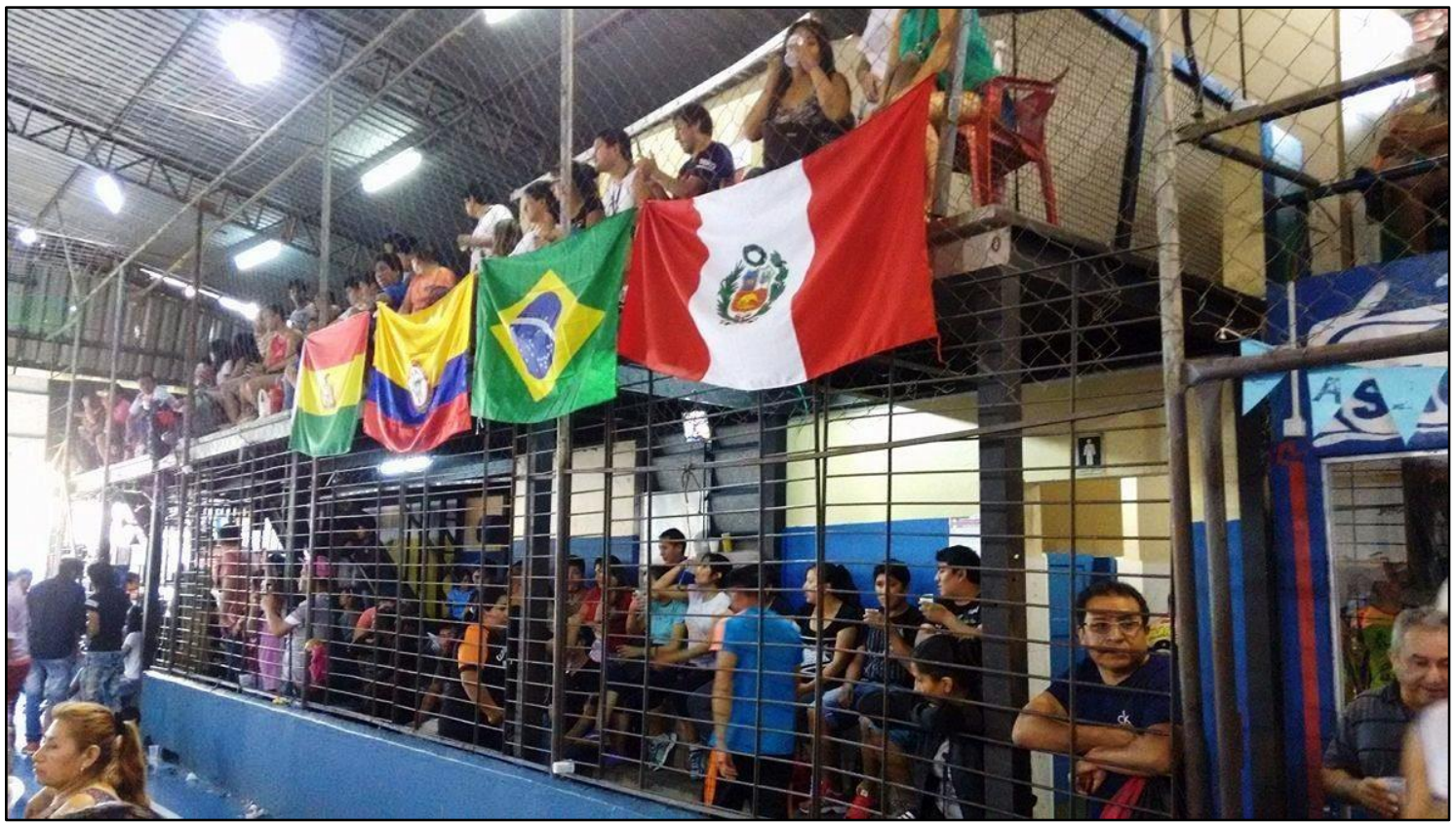

Fonte: Própria autoria.

Figura 19: Troféus para a premiação do final do Campeonato

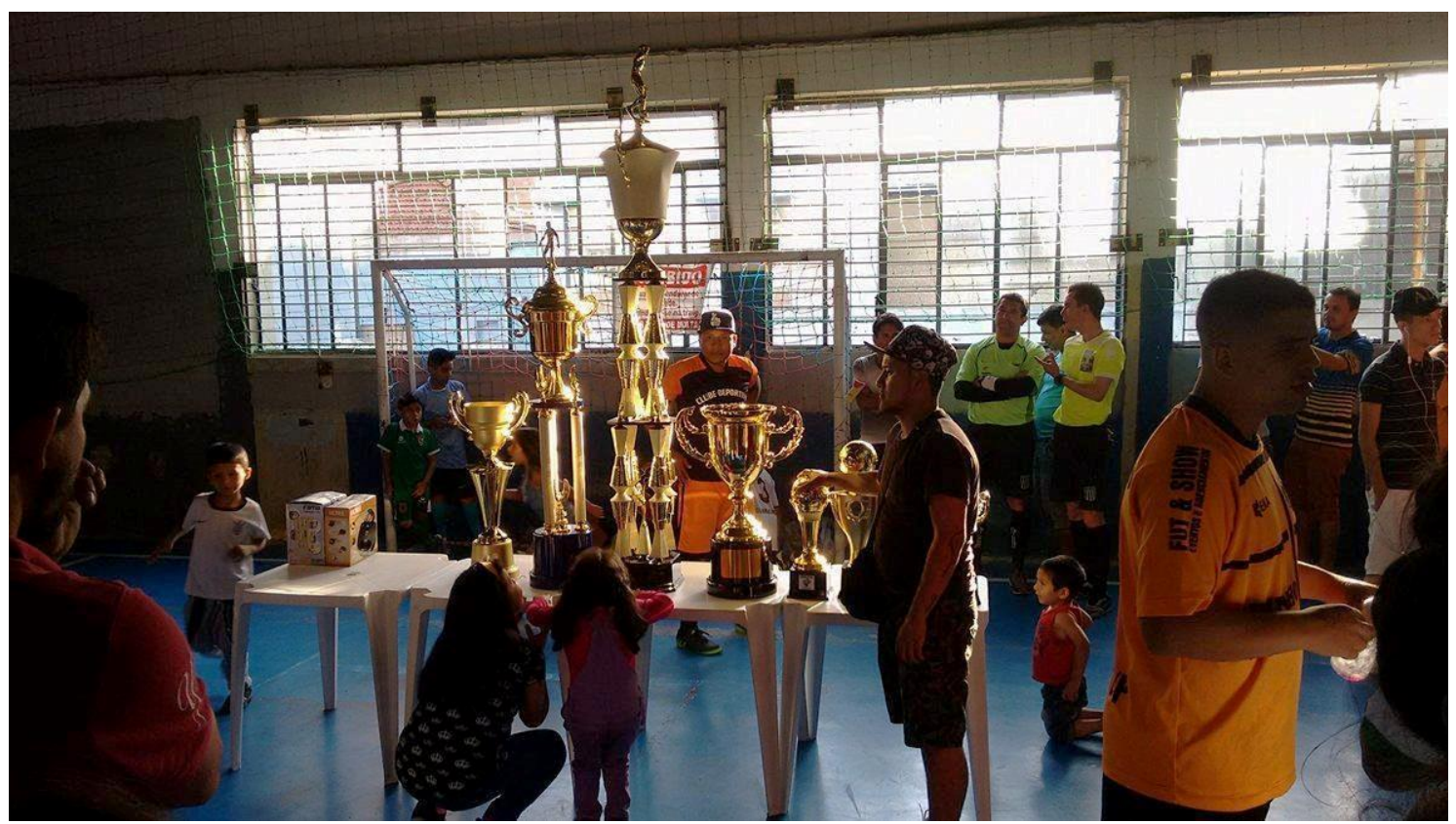

Fonte: Própria autoria. 


\section{CONSIDERAÇÕES FINAIS}

$\mathrm{Na}$ presente pesquisa se objetivou-se analisar o deslocamento e a experiência migratória de peruanos e peruanas trabalhadoras ambulantes na cidade de São Paulo, a traves de suas historias de vida e de observação direta dos espaços onde se desenvolve o cotidiano desse grupo migratório, isto é, da feirinha de madrugada do Brás, do seu lugar de moradia, e dos espaços de lazer popular e de atividades de tempo livre, sendo ao mesmo tempo de grande importância a aproximação da pesquisadora com os entrevistados. Entende-se a sua vez, o trabalho, comida e lazer como dimensões do vivido totalmente interligadas no contexto migratório e como tal precisam ser analisadas em conjunto, aparecendo de maneira imbricada nas observações de campo e nos relatos dos imigrantes.

Os entrevistados, antes de tudo, são imigrantes internos nos seus próprios países, esta imigração se deu geralmente por motivo de trabalho ou de reintegração familiar desde suas cidades de origem nas regiões dos Andes, do litoral ou da Amazônia, com destino a Lima. O percurso do deslocamento de vários peruanos entrevistados passou por outros países da América do Sul, até constatar que no Brasil, especificamente em São Paulo, tinham muitas expectativas de receber apoio devido a uma rede já estabelecida na cidade, rede constituída por familiares ou em alguns casos por oferta de emprego e moradia.

O cenário principal de trabalho de todos os imigrantes entrevistados foi a Feirinha da Madrugada, na qual se encontram trabalhando como comerciantes ambulantes nas pistas ou calçadas do lugar. A atividade como camelo não é nova para eles, já que foi uma atividade praticada na sua fase de imigrantes internos no Peru como uma forma de sobrevivência na capital, chegando a ser em alguns casos uma atividade familiar. O trabalho como comerciantes ambulantes significa para eles maior ganancia e, sobretudo, o significado de independência e a possibilidade de separar-se do patrão gerando assim um sentimento de liberdade e autonomia. Significado que formulam traz suas experiências previas como trabalhadores no Peru, experiências marcadas pela exploração, baixos salários e ausência de benefícios próprio das condições laborais precárias no país de origem, realidade não muito distinta no caso brasileiro e da maior parte dos países da América Latina.

Traz as observações do trabalho de campo e as narrativas dos entrevistados se teve uma maior aproximação à dinâmica da feirinha de madrugada, desde uma 
perspectiva dos próprios camelos imigrantes. A feirinha aparece assim como um cenário de sociabilidades, conflitos e disputas pelo espaço publico, pela proteção e pela identidade. Um lugar onde diariamente acontecem brigas pelo espaço denominado de ponto principalmente entre brasileiros e imigrantes, além de cobros indevidos pelo aluguel e venda da calçada e da pista, assim como cobros de um grupo organizado que oferece segurança. Ante isto, na procura de maior proteção os imigrantes principalmente bolivianos e peruanos se auto organizaram em associações cujas lideranças são imigrantes.

Respeito à moradia, muitos imigrantes recém-chegados no Brasil se estabelecem em ocupações devido aos altos custos do aluguel na cidade paulistana e à existência de redes familiares já estabelecidas nas ocupações. Os espaços que acostumam habitar geralmente são compartilhados com mais outros conterrâneos sendo usados como moradia e lugar de produção da própria mercadoria, porém, existe a expectativa de no futuro terem uma moradia digna com melhores condições de vida. A questão da moradia é um tema de muita importância no contexto migratório. $\mathrm{O}$ fato dos imigrantes ter acesso a uma habitação é muitas vezes uma maneira de romper com formas de exploração e relações de dependência com o patrão, condições às quais se submetem no momento de aceitar vir no país com facilidades de comida e moradia em troca de trabalho excessivo e mal remunerado.

O trabalho como ambulante na madrugada assim como a produção da própria mercadoria são atividades muito desgastantes e cansativas, o que afeta diretamente a disposição dos imigrantes comerciantes para sociabilizar, passear, e realizar atividades de recreação nos finais de semana. Mesmo assim esses imigrantes participam de celebrações populares, fazendo diferencia do que eles chamam de "os outros peruanos" às festas oficiais realizadas pelo consulado. A celebração popular mais pratica pelos ambulantes em contexto migratório é a pollada, festa celebrada pelos imigrantes internos no Peru e que na sua maioria também se dedicam ao comercio ambulante nas ruas da capital peruana. Nas atividades de lazer em contexto paulistano os códigos de sociabilidades próprias da sociedade peruana se reproduzem, tal como as relações de gênero, a diferenciação de classes sociais, entre outros. As festas e celebrações em contexto migratório são um maneira de apropriação do espaço público e possibilitam processos de reterritorialização e sociabilidades entre conterrâneos e outros imigrantes, expandindo suas redes de apoio. 
Contudo, as mudanças das novas ondas migratórias, principalmente da América Latina e da África revelou que o país não é tão acolhedor quanto seu imaginário sugere já que milhares de imigrantes chegados no Brasil tem que afrontar a precariedade na qual se encontra o país em termos de igualdades, direitos e proteção aos migrantes. Como vimos, a maioria deles somente consegue se inserir no setor informal da economia, em situação de trabalho precário, moradia precária e com grandes dificuldades de acesso a politicas publicas. Mesmo com essas deficiências existe um crescimento da autorganização na luta por direitos- ao trabalho, moradia e lazer - visto nesta pesquisa. 


\section{BIBLIOGRAFIA}

AGUIRRE, S. Victimologia de Los Andes Peruanos a partir del fenômeno de violência politica en el Perú. Tese (Doutorado em Direito e Ciencia Politica)Faculdade de direito e Ciencia Politica, Universidad Nacional Mayor de San Marcos. Lima, 2013.

ALTAMIRANO, T. Liderazgo y organizaciones de peruanos en el exterior: Culturas transnacionales e imaginarios sobre el desarrollo. Lima: Fondo Editorial Pontificia Universidad Católica del Peru, 2000.

ANTUNES, R. Adeus ao Trabalho? Ensaio sobre as metamorfoses e a centralidade do mundo do trabalho-16 ${ }^{\text {a }}$ Ed. São Paulo: Cortez, 2015.

BAENINGER, Rosana; PERES, Roberta Guimarães; DEMÉTRIO, Natália Belmonte . Perfil da Imigração Peruana em São Paulo. In: XIX Encontro Nacional de Estudos Populacionais, 2014, Aguas de São Pedro. XIX Encontro Nacional de Estudos Populacionais. Belo Horizonte: ABEP, 2014. v. 1. p. 1.

BEJAR, H. ALVAREZ, M. Las polladas: una estrategia de sobrevivencia en época de crisis económica y política. Lima, 1980-2003. Revista de investigaciones sociales. Vol.14 N²4, pp.259-283. UNMSM/IIHS, Lima, 2010.

BOARINI, M. Higiene e raça como projetos: higienismo e eugenismo no Brasil.. Maringá: Eduem, 2003.

BOULOS, G. Porque ocupamos? Uma introdução à luta dos sem teto. São Paulo: Autonomia literária, 2015.

SILVA, S. Faces da latinidade: Hispano americanos em São Paulo. Texto Nepo 55. UNICAMP, Campinas, 2008.

CASTRO, N. DEDECCA, C. A ocupação na América Latina: tempos mais duros. São Paulo- Rio de Janeiro: Associação Latino-americana de Sociologia do Trabalho, 1998.

DANIEL, Camila. Territorialidades migrantes: um estudo antropológico sobre a Copa Peru- Rio. Revista PerCursos. Florianópolis, v. 15, n.28, p. 120 - 145. jan./jun. 2014.

DIWAN, P. Raça pura: uma historia da eugenia no Brasil e no mundo. São Paulo: Contexto, 2007ESPINOZA, E. El dolor humano: Estudio exploratório sobre la influencia de la violacion sexual em la vida de las mujeres ayacuchanas durante el conflito armado no internacional. Dissertaçao (Mestrado em Sociologia) Faculdade de Ciencias Sociais, Universidad Nacional Mayor de San Marcos. Lima, 2007.

DURÃES, B. J. R. . Trabalho de rua no Brasil e o processo de acumulação capitalista: o trabalhador gratuito. In: $6^{\circ}$ Colóquio Internacional Marx e Engels, 2009, Campinas. $6^{\circ}$ Colóquio Internacional Marx e Engels, 2009. 
FREIRE da SILVA, Carlos. Trabalho informal e redes de subcontratação: dinâmicas urbanas da indústria de confecções em São Paulo. Dissertação (Mestrado em Sociologia) - Faculdade de Filosofia, Letras e Ciencias Humanas, Universidade de São Paulo. São Paulo, 2008.

Das calçadas ás galerias: mercados populares do centro de São Paulo. Tese (Doutorado em Sociologia)- Faculdade de Filosofia, Letras e Ciencias Humanas, Universidade de São Paulo. São Paulo, 2014.

GOBINEAU, J. Essai sur l'inégalité des races humaines. Francia: Firmin Didot, 1855.

GOMES, C. ISAYAMA, H.(Org.) O Direito social ao lazer no Brasil. Autores Associados: Campinas. 2015.

HAESBAERT, R. O mito da desterritorialização: do "fim dos territórios à multiterritorialidades. Rio de Janeiro: Bertrand Brasil, 2004.

Identidades territoriais. In: Rosendhal, Z. e Correa, R. (orgs.) Manifestações da cultura no espaço. Rio de Janeiro: EdUERJ, 1999.

HEIDEMANN, H. O migrantes da racionalização global. In: O fenômeno migratório no limiar do terceiro milênio: desafios pastorais. Rio de Janeiro: Vozes, 1998.

HOFBAUER, A. Uma história de branqueamento ou o negro em questão. São Paulo: UNESP, 2006.

INFORME FINAL DE LA COMISION DE LA VERDAD Y RECONCILIACIONPERÚ. CRV. Tomo VII. Lima, 2003.

IOKOI, Z. Imigrantes invisíveis: a intolerância na cidade, In: Anais do XIX Encontro Regional de Historia. Poder, violência e exclusão. São Paulo: ANPUH-SP. Disponível em http://www.anpuhsp.org.br/sp/downloads/CD\%20XIX/PDF/Conferencias/Zilda_C onfer encia.pdf. 2008.

LEFEBVRE, H. A revolução urbana. Belo Horizonte: UFMG, 2004.

LÉVI-STRAUSS, C. Raça e história. Lisboa: Editorial Presença, 1945.

MAGNANI, Jose Guilherme Cantor. Festa no pedaço: cultura popular e lazer na cidade. 1. Ed. São Paulo: Hucitec, 1998. v. 1. 166 p.

MAGNANI, Jose Guilherme Cantor. De perto e de dentro: notas para uma etnografia urbana. Revista Brasileira de Ciências Sociais, São Paulo, v. 17, n. 49, p. 11-29, 2002.

PAIVA, O. Caminhos cruzados: Migração e construção do Brasil moderno (19301950). São Paulo: EDUSC, 2004. 
PAIVA, O; MOURA, S. Hospedaria de imigrantes de São Paulo. São Paulo: Paz e Terra, 2008.

PEDRAGLIO, S. Cómo se llego a la dictadura consentida. El gobierno de Alberto Fujimori: 1990-1992. Dissertação (Mestrado em Sociologia)- Faculdade de Ciências Sociais, Universidad Nacional Mayor de San Marcos. Lima, 2014.

QUIJANO, A. Colonialidad del poder y clasificación social. Journal of WorldSystems Research, VI,2, Summer/Fall. University of California, 2000. PP 342-386.

RAEDERS, G. O conde de Gobineau no Brasil. São Paulo: Paz e terra, 1996.

RAFFESTIN, C. Por uma geografia do Poder. São Paulo: Ática, 1993.

ROLNIK, R. Guerra dos lugares: a colonização da terra e da moradia na era das finanças. São Paulo: Boitempo. 2015.

SANDOVAL, P. El olvido está lleno de memoria. Juventud universitaria y violencia política en el Perú: la matanza de estudiantes de La Cantuta. Trabalho conclusão de curso (Licenciatura em Antropologia) - Facultad de Ciencias Sociales, Universidad Nacional Mayor de San Marcos. Lima, 2002.

SANTOS, M. O espaço dividido: os dois circuitos da economia urbana dos países subdesenvolvidos. São Paulo: Edusp, 2004.

SAYAD, A. A imigração ou os paradoxos da alteridade. São Paulo: Edusp. 1998.

STEPAN, N. A hora da Eugenia: raça, gênero e nação na América Latina. Rio de Janeiro: Editora Fiocruz, 2005.

VAN DIJK, T. Racismo e discurso na América Latina. São Paulo: Contexto, 2008. 